
Memoirs of the Swiss Academy of Sciences

Volume 104

Reinhart A. Gygi

Integrated Stratigraphy

of the Oxfordian and

Kimmeridgian (Late Jurassic) in

northern Switzerland and

adjacent southern Germany

Birkhäuser Verlag

Basel · Boston · Berlin 


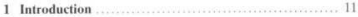

1.1 Geographical and palaeogeographical seuting ..... 11

1.2 Previous work ........................................ 11

1.3 Aim and structure of this paper . . . .

1.4 Methods, classifications and terminology .......... 16

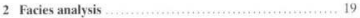

2.1 Lithofacies.............. 19

2.1.1 Basinal facies ................................ 19

2.1.1.1 Basinal argillaceous mudstone (marl) .... . . 19

2.1.1.2 Basinal lime mudstone ........... 19

2.1.1.3 Basinal iron oolite ................20 20

2.1.1.4 Basinal spongolite ...................20 20

2.1.1.5 Businal oncolite ................... 20

2.1.1.6 Glauconitic rocks .................. 21

2.1.2 Facies of the carbonate platform slope .....2 21

2.1.2.1 Debris flows ........................ 22

2.1 .2 .2 Spiculite ....

2,1.3 Facies of the carbonate platform margin ... 22

2.1.3.1 Coral bioherms ..................... 22

$2.1,3,2$ Oolite bars .......................... 22

2.1.4 Facies of the lagorn ........................ 22

2.1 .4 .1 Tidal deltas ......................... 22

2.1.4.2 Oncolite ............................23

2.1 .43 Coral bioherms ...................... 25

2.1.4.4 Sandy quartz siltstone .............2. 25

2.1.4.5 Dolosparite ........................ 26

2.1.5 Tidal flat facies .............................. 26

2.1.5.1 Mudstone with prism cracks ...... 26

2.2 Biofacies 27

2.2.1 Siliceous sponge assemblages .............. 27

2.2.2 Ammonite assemblages ..................... 27

2.2.3. Bivalve assemblages .......................... 28

2.2.4 Coral assemblages ............................. 28

2.2 .5 Cladocoropsis assemblages ................... 28

2.2 .6 Microbialitic assemblages ................... 29

2.3 Fossil-dominated sediments ....................... 29

2.3.1 Siliceotrs sponge-dominated

biostromes and bioherms ..................... 29

2.3.2 Coral-dominated biostromes and

bioherms ................................... 29

2.3.3 Lagoonal fossil-dominated sediments ....... 30

2.4 Vertical and lateral facies successions .............. 30

3 Lithostratigraphy …................................. 31

3.1 The stratigraphical sections .......................... 31

3.1 .1 Transect Bure-Biel ............................ 31

3.1.1.1 Section RG 454 Bure JU.

well BUR 2 ........................ 31

3.1.1.2 Section RG 340) Porrentruy JU, quarry of Le Banné
3.1.1.3 Section RG 359 Bressaucourt

JU, drinking water well ........ 31

3.1.1.4 Section RG 350 Courgenay $\pi$. Chemin Paulin road ............... 32

3.1.1.5 Section RG 443 St-Lisanne JU. exploration well near La Coperie farm .................. 32

3.1.1.6 Sections RG 314,315 Sornetan BE. Pichoux gorge ......... 32

3.1.1.7 Sections RG, 307, 458 Péry BE, La Charuque quarry ............... 33

3.1.2 Transect Delèmont-Grenchen ................ 35

3.1.2.1 Section RG 366 Delémont. Vorbourg chapel ................... 35

3.1.2.2 Sections RG 373,389,451 Vellerat JU, Peute Roche ..... 35

3.1.2.3 Section RG 377 Rebeuvelier JU, La Roche St-Jean $\quad 36$

3.1.2.4 Seetion RG 392 Moutier BE, Moutier gorge. Arête du Raimeux 37

3.1.2.5 Section RG 390 Moutier BE. southern part of Moutier gorge . . . 37

3.1.2.6 Section RG 381 Moutier BE. Court gorge 39

3.1.2.7 Section RG 384 Selzach SO. road through Lochbach gorge ...... 39

3.1.3 Transect Liesberg-Solothurn ................. 40

3.1.3.1 Section RG 280 Liesberg BL. clay pit of Ampthil .................40

3.1.3.2 Section RG 306 Liesberg BL. clay pit of Hinter Chestel and quarry of Chestel .................... 40

3.1.3.3 Section RG 398 Liesberg BL. limestone quarry ...................42

3.1.3.4 Section RG 402 Röschenz. road to Muli 43

3.1.3.5 Section RG 399 Bärschwil SO. landslide west of Vögeli farm ......43

3.1.3.6 Section RG 400 Corban JU, gorge northeast of La Providence farm . 44

3.1.3.7 Section RG 404 Mervelier JU, gorge of the Scheulte river. western flank ....................... 45

3.1.3.8 Section RG 406 Vermes JU. ravine southeast of La Kohlberg farm ............................... 46

3.1.3.9 Section RG 356 Grandval BE, landslide of La Morte Roche ....... 46

3.1.3.10 Section RG 429 Welschenrohr SO, gorge south of Harfergraben 
3.1.3.11 Sections RG 430,431

Gänsbrunnen SO, cantonal road and quarry

3.13.12 Section RG 433 Oberdorf SO, gorge and quarry north of Whaberhussli

3.1.3.13 Section RG 434 Lommiswil SO/Oberdorf SO, Steingrueben quarries ............................ 49

3.1.4 Region of Balsthal ....................... 50

3.1.4.1 Section RG 440 Rumisberg BE, Rüttelhorn ......................... 50

3.1.4.2 Section RG 438 Balsthal SO, road through Steinebach gorge .... 50

3.2 Formations and members ......................... 5.

3.2.1 Herznach Formation ...................... 51

3.2 .2 Bärschwil Formation ....................... 52

3.2.2.1 Renggeri Member .................. 52

3.2.2.2 Sornetan Member .................. 53

3.2.2.3 Liesberg Member ..................... 54

3.2 .3 St-Ursanne Formation ........................ 54

3.2.3.1 Grellingen Member .................. 55

3.2.3.2 Delémont Member ................... 55

3.2 .3 .3 Tiergarten Member ................ 56

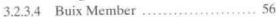

32.4 Pichoux Formation ........................... 57

3.2 .5 Vellerat Formation ........................... 58

3.2.5.1 Vorbourg Member ................... 58

3.2.5.2 Röschenz Member ................... 58

3.2.5.3 Hauptmumienbank Member...... 59

3.2.5.4 Bure Member ........................ 59

3.2.5.5 Oolithe Roussc Member .......... 59

3.2 .6 Gunsberg Formation ........................ 59

3.2 .7 Courgenay Formation .......................... 60

3.2.7.1 La May Member .................... 61

3.2.7.2 Porrentruy Member ................ 61

3.2.8 Bilsthal Formation ............................61 61

3.2.8.1 Steinebach Member ................6] 61

3.2 .8 .2 Laufen Member..................... 62

3.2.8.3 Verena Member ............................ 62

3.28 .4 Holzflue Member ................... 63

3.28 .5 Olten Member ......................64 64

3.2.9 Reuchenette Formation ......................65 65

4 Biostratigraphy ............................................ 69

4.1 Stratigraphically significant ammonite taxa ........ 69

4.1.1 Otheloceras (Ochetoceras) hispidum

(OPFEL) ..........................................69 69

4.1.2 Neoprionoceras delmontanum

(OPPEL) ............................................ 69

4.1 .3 Trimarginites trimarginatus (OPFEL) .......... 70

4.1.4 Trimarginites sienoritynchus (OPPEL) ........ 71

4.1.5 Tarameiliceras (Proscaphites) anar

(OPFEL) ......................................... 71

4.1.6 Taramelliceras (Metahaploceras) wenzeli

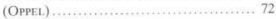

4.1.7 Creniceras renggeri (OPpeL) ................. 72

4.1.8 Streblites tenuilobaitus (OPPEL) ………..... 73
4.1.9 Ouensiedtoceras lamberti lamberti

(I. SowEkHY) 73

4.1.10 Cardioceras (Scarburgiceras)

paucicostatum LANGE

4.1.11 Cardioceras (Scarburgiceras)

scarburgense (Young \& BrrD) ............... 74

4.1.12 Cardioceras (Scarburgiceras)

praecordatum R. DouviL. LE ................... 74

4.1.13 Cardioceras (Scarburgiceras)

bukowskii MAIRE

4.1.14 Cardioceras (Pavloviceras) cl. mariae

(D'ORAigny)

4.1.15 Cardioceras (Cardioceras) costicardia valgare ARKELL ............................... 75

4.1.16 Cardioceras (Cardioceras) cordatum

(J. SowerBy) …................................. 75

4.1.17 Cardioceras (Cardioceras) persecans

(S. Buckman) ................................ 76

4.1.18 Cardioceras (Cardioceras) cf stella

AkкеLL............................................ 76

4.1.19 Cardioceras (Subvertebriceras)

costellatum S. BuckMaN ....................... 76

4.1.20 Cardioceras (Subveriebriceras)

densiplicatum BoDEs ........................ 77

4.1.21 Cardioceras (Maltoniceras) schellwieni

BODEN ......................................... 77

4.1.22 Cardioceras (Miticardioceras) renuiserratum (OPPEL)

4.1.23 Amoeboceras glosense

(Bigot \& BrasiL)

4.1.24 Amoeboceras ef serratum

(J.SOWERBY)

4.1.25 Amoeboceras ovale

(QUENSTEDT)

4.1.26 Amoeboceras tuberculatoalternans

(NikITIN) ......................... 79

4.1.27 Perisphinctes (Neomorphoceras) chapuisi

(OPPEL) ......................................... 79

4.1.28 Perisphincles (Neomorphoceras) collinui

(OPPEL) ......................................... 80

4.1.29 Perisphincies (Otosphinctes) paturattensis

DE LoRIOL ..................................... 80

4.1.30 Perisphincies (Olosphinctes) siemiradzkii

ENAY ................................... 80

4.1.31. Perisphinctes (Arisphinctes) plicatilis

(J. SOWEkBY) .................................. 81

4.1.32 Perisphinctes (Arisphinctes) helenae

De Ruaz ...................................... 82

4.1.33 Perisphinctes (Dicholomosphinctes)

aniecedens SALFELD ....................... 82

4.1.34 Perisphinctes (Dichotomosphinctes)

elisabethae DE RIAZ

4.1.35 Perisphinctes (Dichotomosphinctes)

luciaeformis ENAY

4.1.36 Perisphinctes (Dichotomoceras) rotoides

RONCHADZE ....................................... 84

4.1.37 Perisphinctes (Dichotomoceras)

stenocycloides SIEMIRADZKI 
4.1.38 Perisphinctes (Dichotomoceras) bifurcatoides ENaY

4.1.39 Perisphinctes (Dichotomoceras) duongae MEL.ENDEZ .

4.1.40 Perisphinctes (Dichotomoceras) ef. bifurcatus (QUENSTEDT) ....................

4.1.41 Subdiscosphinctes (Stabdiscosphinctes) lucingae (FAVRE)

4.1.42 Subdiscosphinctes (Aureimontanites) wojciechi n. sp.

4.1.43 Subdiscosphincles (Aureimontanites) cracoviensis (SIEMIRADZKI)

4.1.44 Larcheria schilli (OPPEL)

4.1.45 Passendorferia (Passendorferia) ziegleri

(Brochwicz-Lewinski)

4.1.46 Passendorferia (Enayiles)

birmensdorfensis (MOESCH)

Wegeter gredingansis (WECELI

4.1 .48 Idoceras bolderum (OPpEL)

4.1.49 Subnebrodites planula

(QUENSTEDT)

4.1.50 Subnebrodites laxevolutios

(Fontannes)

4.1.51 Subnebrodiles schroederi (WEGELE)

4.1.52 Orthosphinctes (Orthosphinctes) colubrinus (REINECKE)

4.1.53 Orthesphinctes (Praeataxioceras) sp. gr. laufenensis (SIEMIRADZKI)

4.1.54 Atnxioceras (Parataxioceras) lothari huguenini ATROPS

4.1.55 Ataxioceras (Parataxioceras) ef. psetidoeffrenatum WEGELE

4.1.56 Ringsteadia suebica n.sp.

(REINECKE)

4.1.58 Sumeria (Sutneria) galar galar (OPPEL) ....

4.1.59 Sutneria (Sutneria) platynota

(REINECKE)

4.1.60 Protophites christoli (BEAUDOUIN)

4.1.61 Gregoryceras (Psendogregoryceras) iteni JEANNEI

4.1.62 Gregoryceras (Gregoryceras) tenuisculptum Gvat

4.1.63 Gregoryceras (Gregoryceras) transversarium (QUENSTEDI)

4.1.64 Gregoryceras (Gregoryceras) riazi

(DE Grossouvre)

4.1.65 Euaspidoceras hypselum (OPPEL)

4.1.66 Epipeltoceras bimammatum (OUENSIEDT) 101

4.1.67 Epipehoceras cf. bimammatum

(OUENSTEDT)
4.1.68 Orthaspidoceras uhlandi (OPPEL)

4.2 The vertical range of the taxa ................. 102

\section{Results and discussion}

5.1 The origin of lime mud

5.1.1 Bioerosion of hard substrates

like reefs and limestone coasts in

warm climates

5.1.2 Algac

5.1.3 Nannoplankton

5.1.4 Inorganically precipitated mud

5.2 Synsedimentary tectonics

5.2.1 Regional, endogenic subsidence ............ 105

5.2.2 Smaller-scale differential subsidence...... 105

5.2 .3 Local tectonism ............................. 105

5.2.4 Exogenic subsidence ......................................... 105

5.3 Eustatic sea-level changes ......................... 105

5.4 Depositional sequences ............................. 105

5.5 Biochronology: ammonite zones and subzones ... 106

5.5.1 The lower boundary of the

Oxfordian Stage ............................ 106

5.5.2 Mariae and Cordatum Zones ............... 106

5.5 .3 Transversarium Zone ..................... 106

5.5.3.1 Densiplicatum Subzone ........... 106

5.5.3.2 Antecedens Subzone ............. 107

5.5.3.3 Luciaeformis Subzone ............. 107

5.5.4 Bifurcatus Zone ......................... 107

5.5.5 Bimammatum Zone ........................ 107

5.5.6 Planula and higher Zones ................. 107

5.6 The boundary between the Oxfordian and

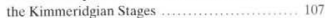

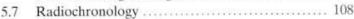

5.8 Magnetochronology .............................. 108

5.9 Correlation ...................................... 108

5.10 Palaeogeography and history of

sedimentation

108

Acknowledgments

Summary

Résumé

Zusammenfassung

References

Plates 1-15

Caption to Plate 16-44.

Plates 16-44 (in the back cover) 


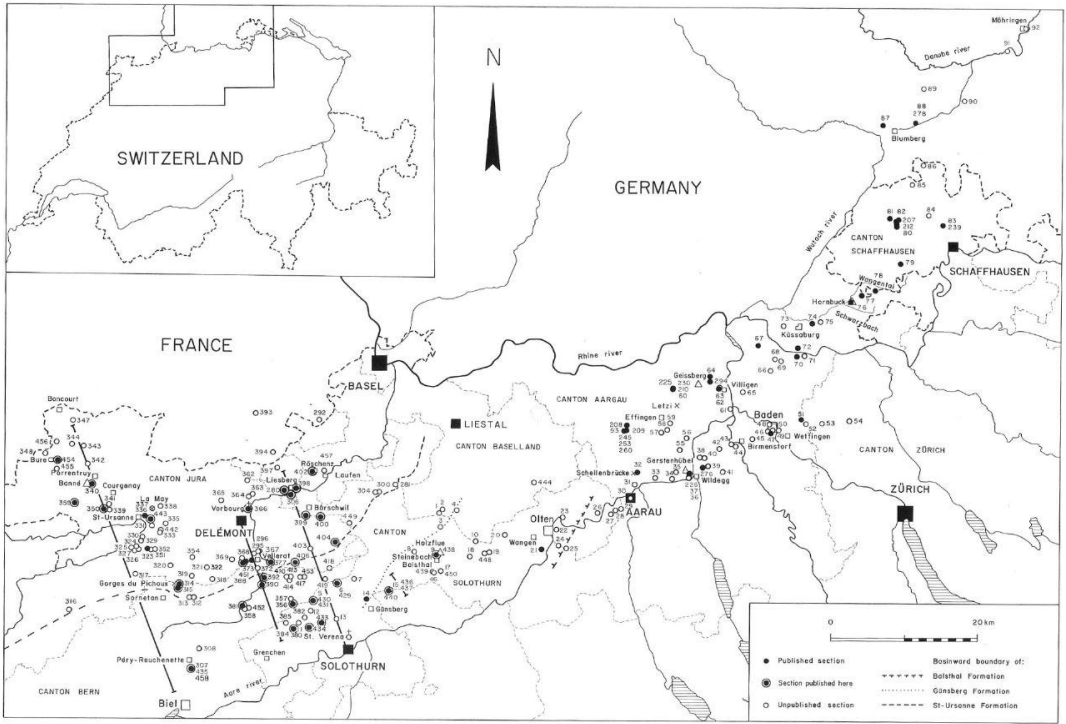




\subsection{Geographical and palaeogeographical setting}

The measuring of detailed sections and the excavation of fossils were done in an arca which is confined to the west by a line between Boncourt in Canton Jura and Biel in Canton Bern (fig. 1). The belt of outcrops becomes narrower towards the east and then runs northeast from Canton Aargau to Möhringen on the Danube river in southern Germany. This whole area is where the Burgundy platform (PURSER 1979) interfingers with sediments of the rhodano-swabian epicontinental sea which was situated adjacent to northern Tethys (fig, 63). The whole area was transformed into an epicontinental sea (fig. 2) by the worldwide Callovian transgression which also flooded the Dalle nacrée carbonate platform in the carly Callovian.

\subsection{Previous work}

Stratigraphic exploration of the Swiss Jura range began before 1820. Merian (1821) described the Jurassic sediments in the ar ea of Basel for the first time and gave a short and appropriatc description of the principal lithostratigraphic units. Merian was aware that fossils were a means for correlation. but he stated that fossils were not known well enough at the time for this purpose. Therefore he correlated strictly lithostratigraphically He correlated the marls of the Barschwil Formation of the earis and middle Oxfordian in the central Jura with the marls of the Effingen Member of the middle and late Oxfordian in the eastern Jura range (fig. 3). He also compared the coral limestones of the St-Ursanne Formation on the platform with the basinal micritic limestones of the Villigen Formation in Canton Aargau.
Fig. 2: Palaeogeographical overview of Europe in the Late Jurassic.

After Ziegler (1988, pl.13). sinplified.

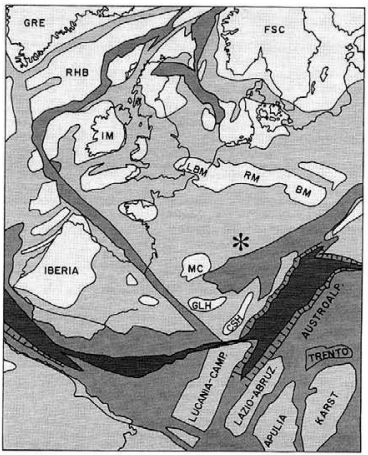

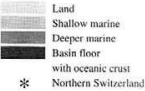

BM Bohcmian Massif CSH Corsica-Sardinia High FSC Fennoscandia GLH Golfe de Lion High GRE Greenland IM Irish Massif LBM London-Brebant Massif MC Massif central RHE Reckall-Hatton Bank RM Rhenish Massif

Fig. 1: Locations with the numbers of the sections measured between 1962 and 1905 . Black eireles are sections published in:
Grat $(1969)$
RG 1-93
GYGT (1973):
RG 226
Gral (1977):
RG 51b, 81b, 208-210,212.230
Grat el al. (1979):
RG 276
GYGI (1982)
RG $280,306,307,315,336$

Empty circles are unpublished sections which are only deseribed in the author's fieldbooks which ean te secn at request in the Museuru of Natural History Basel. Squares of different sizes are villages, towns or cities. Triangles are hills or mountains. A cross is a locality in the field. 


\begin{tabular}{|c|c|c|}
\hline RG & 1 & Reigoldswil BL \\
\hline $\mathrm{RG}$ & 2 & Reigoldswil BL \\
\hline $\mathrm{RG}$ & 3 & Mumliswil SO \\
\hline $\mathrm{RG}$ & $4 *$ & Waldentoure BL \\
\hline RG & 5 & Gänsbrunnen $\mathrm{SO}$ \\
\hline$R G$ & 6 & Welschenrohr SO \\
\hline RG & 7 & Herbetswil SO \\
\hline RG & 8 & Laupersdorf SO \\
\hline RG & 9 & Balsthal SO \\
\hline $\mathrm{RG}$ & 10 & Holderbank $\$ O$ \\
\hline RG & 11 & Selzach SO \\
\hline RG & 12 & Oberdorf SO \\
\hline RG & 13 & Oberdorf 50 \\
\hline $\mathrm{RG}$ & 14 & Günsberg $5 O$ \\
\hline RG & 15 & Acdermannsdorf $\mathrm{SO}$ \\
\hline RG & 16 & Balsthal SO \\
\hline RG & 17 & Balsthal SO \\
\hline $\mathrm{RG}$ & 18 & Oberbuchsiten $\mathrm{SO}$ \\
\hline RG & 19 & Egerkingen SO \\
\hline $\mathrm{RG}$ & 20 & Hăgendorf $\mathrm{SO}$ \\
\hline RG & $21 *$ & Olten SO \\
\hline RG & 22 & Olten SO \\
\hline RG & 23 & Winznau SO \\
\hline $\mathrm{RG}$ & 24 & Aarburg AG \\
\hline RG & 25 & Oftringen $\mathrm{AG}$ \\
\hline RG & 26 & Niedergüsgen SO \\
\hline $\mathrm{RG}$ & 27 & Sehönenwerd SO \\
\hline$R G$ & 28 & Schonenwerd SO \\
\hline$R G$ & $29 \div$ & Wöschnau SO \\
\hline RG & 30 & Aarau \\
\hline$R G$ & 31 & Kuttigen $\mathrm{AG}$ \\
\hline $\mathrm{RG}$ & 32 & Küttigen AG \\
\hline RG & 33 & Biberstein $A G$ \\
\hline $\mathrm{RG}$ & 34 & Auenstein $\mathrm{AG}$ \\
\hline RG & 35 & Auenstein AG \\
\hline RG & 36 & Auenstein AG \\
\hline $\mathrm{RG}$ & 37 & Aucnstein $\mathrm{AG}$ \\
\hline $\mathrm{RG}$ & 38 & Schinznach-Bad AG \\
\hline RG & 39 & Lupfig $\mathrm{AG}$ \\
\hline RG & 40 & Scherz AG \\
\hline $\mathrm{RG}$ & 41 & Brunegg $\mathrm{AG}$ \\
\hline $\mathrm{RG}$ & $42^{*}$ & Lupfig AG \\
\hline $\mathrm{RG}$ & 43 & Mulligen AG \\
\hline $\mathrm{RG}$ & 44 & Mülligen AG \\
\hline RG & 45 & Birmenstorf AG \\
\hline RG & 46 & Baden AG \\
\hline $\mathrm{RG}$ & 47 & Baden AG \\
\hline $\mathrm{RG}$ & 48 & Baden AG \\
\hline $\mathrm{RG}$ & 49 & Baden AG \\
\hline $\mathrm{RG}$ & 50 & Baden AG \\
\hline RG & 51 & Oberchrendingen AG \\
\hline RG & 52 & Unterehrendingen AG \\
\hline $\mathrm{RG}$ & 53 & Schleinikon $\mathrm{ZH}$ \\
\hline RG & 54 & Regensberg $\mathrm{ZH}$ \\
\hline RG & 55 & Schinznach-Dort AG \\
\hline RG & 56 & Schinznach-Dorf AG \\
\hline $\mathrm{RG}$ & 57 & Zeihen AG \\
\hline $\mathrm{RG}$ & 58 & $\operatorname{Linn} \mathrm{AG}$ \\
\hline RG & 59 & Effingen AG \\
\hline RG & 60 & Gansingen AG \\
\hline RG & 61 & Rufenach $\mathrm{AG}$ \\
\hline RG & 62 & Villigen AG \\
\hline RG & $63 *$ & Villigen AG \\
\hline RG & 64 & Villigen AG \\
\hline RG & $65^{\circ}$ & Wärenlingen AG \\
\hline RG & $66 *$ & Unterendingen AG \\
\hline RG & 67 & Zurach AG \\
\hline RG & 68 & Rekingen $\mathrm{AG}$ \\
\hline RG & 69 & Baldingen $\mathrm{AG}$ \\
\hline RG & $70^{\circ}$ & Mcllikon AG \\
\hline RG & $71^{2}$ & Rùmikon AG \\
\hline RG & 72 & Reckingen $\mathrm{D}$ \\
\hline $\mathrm{RG}$ & 73 & Dangstetten D \\
\hline RG & 74 & Geisslingen D \\
\hline RG & 75 & Geisslingen D \\
\hline
\end{tabular}

Hotel Wasserfalle

Tunnel east of Schelmenloch

Gorge south of Genneten

Brocheni Flue

Cantonal road and quarry

Gorge south of Harzergraben

Upper Wolfschlucht gorge

Mausteren

Steine bach gorge

Road bend south of Lochhus

Western cliff of Hasenmatt

Rischgraben

Gorge east of Nesselboden

Gschlief landslide

Horngraben

Von Roll quarry. Klus

Chluser Roggen

Muhlebach ravine

Flüeloch gorge

Road south of Allerheiligenberg

Quarry on Mt. Born

Hardflue

Cliff east of Aare bridge

Sialifluc

Quarry south of Heidenloch

Ouarry west of church

Cliff south of cemetery

Quarry at Halden

Ouarry in Roggenhausen valley

Exploration well near former post office

Zurlinden quarry

Road near Schellenbracke

Quarry east of Thegi

Quarry near public swimming pool

Halden

Ouarry west of Fahr

Quarry of Jakobsberg

Waterfall west of Gupf

In Berg

Quarry of Scherzberg

Brunegg castle

Quarry of Guggerhubel

Schambelen

Quarry east of Eiteberg

Quarry northwest of Oberhard

Quarry of Hundsbuck

Railroad cut

Martinsberg

Road tunnel below Stein

Quarry east of Landvogtei castle

Quarry of Hinterstein

Mt. Lägern, Burghorn

Ruin of Altlägern

Quarry northeast of town

Grund

Mannlehen west of Wallbach

Quarry at Laufacker

Quarry at Hundruggen

Quarry beside B $\$$ zberg road

Eisengraben

Quarry north of Lauffohr

Schrannechopf

Ravine west of Villigen

Mandacher Höhe

Former quarry

Tal

Road southwest of town

Exploration well Im Berg

Waterfall of Bistig

Large quarry

Former quarry

Ouarry of In den Mösern

Berchenwald

Steiggraben

Road west of Egg
$619.750 / 247.000$

$610.960 / 247.500$

$619.830 / 245.300$

$622.030 / 247.590$

$602.070 / 234.910$

$605.550 / 237.490$

$608.190 / 238.120$

$616.30 \times / 242.050$

$619.370 / 241.350$

$624.880 / 243.190$

$600.700 / 232.180$

$602.100 / 233680$

$605.550 / 232.720$

$609.540 / 235.380$

$613.120 / 236.790$

$619.030 / 239.370$

$619.780 / 239.320$

$623.700 / 241.320$

$626.600 / 241.700$

$628.440 / 244.150$

$633.900 / 242.280$

$635.550 / 244.980$

$636.480 / 246.500$

$635.910 / 243.050$

$636.880 / 241.990$

$641.620 / 246.970$

$643.200 / 247.100$

$643,700 / 247.660$

$644.530 / 247.930$

$645.760 / 249.3410$

$646.550 / 251.000$

646.450252 .880

$649.230 / 251.760$

651.660251 .680

652.140252 .760

653.550251 .880

653.900252400

655330254.800

656.230253 .490

$655.750 / 255.200$

$658.470 / 252.720$

658.000256000

$659370 / 256.720$

$660.100 / 256.330$

$662.000 / 257.220$

$664.670 / 258.230$

$664.750 / 258.050$

$664.900 / 259.360$

$665,420 / 258,450$

$665780 / 258.420$

$669.00 \times 1260.070$

$669.680 / 259.330$

$672.070 / 259.480$

$675.700 / 259.780$

$651.830 / 255.700$

$653.800 / 257.270$

$650.190 / 258.190$

$650.950 / 258.650$

$651.400 / 259.540$

$651.560 / 264.080$

$659.730 / 261.950$

$657.6 \times 0 / 264.020$

$658.050 / 264.240$

$656.650 / 265.880$

$661.270 / 264.080$

$664.800 / 266.630$

$663.200 / 269.980$

665.500268 .500

$666.280 / 268.160$

$668,330 / 268.730$

$669.280 / 268.700$

$668.450 / 269.840$

$666.500 / 272.750$

$670.4 \times 0 / 273.080$

$671.550 / 273.450$
$619780 / 247780$

$619.670 / 247.250$

$619.880 / 245.010$

$621.93(1) 247530$

$602.150 / 234.450$

$605.630 / 237.400$

608.280/237.930

$616.200 / 241.750$

$619.350 / 241.280$

$624.850 / 243.130$

$600.760 / 232.160$

$601.940 / 233.750$

$605.700 / 232.650$

$609.500 / 235.620$

$613.050 / 236,870$

$618.950 / 239.450$

$619.770 / 239.370$

$623.800 / 241.240$

$626.680 / 241.600$

$628.480 / 244.050$

$634.080 / 242.300$

$635.550 / 244.920$

$636.550 / 246.500$

$635.900 / 243.080$

$636.930 / 241,960$

$641.630 / 246980$

$643.200 / 247.060$

$643.690 / 247.670$

$644.530 / 247930$

$645.760 / 249.340$

$646.620 / 251.030$

$646,460 / 252.870$

$649.240 / 251.750$

$651.670 / 251.630$

$652.130 / 252.750$

$653.600 / 251.870$

$653.780 / 252.030$

$655.380 / 254.710$

$656.230 / 253.490$

655.780255 .220

$658.500 / 252.650$

$658.000 / 256.010$

$659.370 / 256.710$

$660.100 / 256.310$

$661.9 \mathrm{~g} 0 / 257.200$

$664.700 / 258.200$

$664.910 / 258.10 x$

$664.880 / 259,380$

$665.400 / 258.350$

$665.800 / 258.380$

$669.090 / 260.070$

669.650259 .280

$672.200 / 259.470$

675.870259 .830

$651.850 / 255.640$

$653,810 / 257.310$

$650.230 / 258.120$

$650.960 / 258.620$

$651.390 / 259.530$

$651.560 / 264.080$

$659.740 / 261.980$

$658.100 / 264.000$

$658.040 / 264.230$

$656.650 / 265.880$

$661.280 / 264.070$

$664.800 / 266.610$ 663.200/269.980

$665.500 / 268.500$

$666.250 / 268.140$

668.300268 .620

$6619.280 / 268.700$

$668.450 / 269.840$

$666.500 / 272.750$

$670.600 / 273.010$

$671.560 / 273.400$ 
Eraingen D

Weisweil D

Wikhingen SH

Neunkirch SH

Siblingen SH

Gächlingen SH

Siblingen SH

Schaffhausen

Hemmental SH

Beggingen SH

Bargen $\mathrm{SH}$

Achidorf D

Blumberg D

Furstenberg D

Leipferdingen D

Immendingen D

Möhringen D

Ueken AG

Siblingen SH

Ueken AG

Ueken AG

Gansingen AG

Siblingen SH

Veltheim AG

Gansingen AG

Schaffhausen

Herznach AG

Herznach AG

Hernach AG

Holderbank AG

Blumberg D

Liesberg BL

Nunningen \$O

Leymen $\mathrm{F}$

Villigen AG

Vellerat JU

Vellerat JU

Zullwil SO

Fehren SO

Lieslyerg BL

Péry BE

Pery BE

Souboz BE

Souboz. BE

Soubor. BE

Souboz BE

Souboz BE

Sornctan BE

Sornetan BE

Le Bémont JU

Saulcy JU

Soulce JU

Soulec JU

Undervelief JU

Soulce JU

Soulce JU

Glovelier JU

St-Ursanne JU

St-Brais JU

St-Ursanne JU

St-Brais JU

St-Ursanne JU

St-Ursanne JU

St-Uisanne JU

Boćcourt JU

Boécourt JU

St-Ursanne JUt

St-Ursanne JU

Asuel JU

Courgenay JU

Porrentruy JU

Courgenay JU

Courchavon JU

Courtemaiche JU

Courtemaiche JU
Hornbuck north of Riedern

Ravine southeast of village

Mulitobel south of Osterfingen

Quarry of Tenggibuck

Siblingen, Schlossranden

Rackolterenbuck

Steimürlichopf

Summerhalde

Quarry of township

Im wisse Rise

Morgenhalde

Landslide west of Eichberg

Iron ore pit at Stoberg

Schächer

Quarry northeast of railway station

Hill south of railway bridge

Kreuzhaide

Iron mine of Herznach

Water conduit in Churz Tal

Excavation on Brunnrain

Iron mine of Herznach

Eisengraben

Shooting range in Churz Tal

Quarry of Unteregg and Steibitz road cut

Excavation northwest of Eisengraben

Summerhalde

Iron mine

Iron mine

Iron mine

Quarry of Chalch

Iron ore pit at Stoberg

Clay pit of Ampthil

Gorge south of Lochmatt

Quarry west of Landskronberg

Quarry of Gabechopf

Champs de la Joux

Road to Forét de la Cendre

Quarry at Eichlenberg

Ibach gorge

Clay pit and quarry of Chestel

Quarries of La Charuque-Reuchenette

Sous la Verriere

Le Beugle

Le Beugle

Combe des Raverattes

Montaigu

Noir Bos

Pichoux gorge

Pichoux gorge

Cras du Plainat

Road to Lajoux

Vieilles Vies

Le Golat

Montépoirgeat

Peute Cóte, western slope

Peute Cotc, eastern slope

Foradrai

Haute Cóte

Sous les Errauts

Northwest of La Seigne Dessus

Rock eastnortheast of Les Errauts

West of La Seigne Dessous

Above Plan du Noyer

Road cut west of Montmelon

Mont Russelin

Cantonal road at Ordon

Railway station and lime works

La May

Côte du Frêne

Road to Vacherie Mouillard

Quarry east of Le Banné hill

L'Alombre aux Vaches

Sur le Tunnel

Quarry east of railway station

Ouarry of Sur Montni
$675.650 / 276.100$

$677.430 / 276.860$

$679.125 / 277.450$

$682.470 / 281.100$

$682.000 / 286.160$

$680.980 / 287.240$

$682.130 / 287.060$

$688.080 / 286340$

$686.450 / 287.830$

$684.300 / 291.600$

$685.700 / 294.580$

$6 \times 0.230 / 300.430$

$684.240 / 300.210$

$3.468 .150 / 5.305 .450$

$3.474,360 / 5,303,630$

$3.480 .470 \times 5.310 .840$

$3.483 .070 / 5.313 .560$

ca. $645.250 / 258.550$

$682.130 / 287.060$

$645.480 / 259.180$

$645.150 / 258.700$

$651.710 / 264.070$

$682.100 / 286.870$

$653.950 / 253.000$

$651.500 / 264.130$

$688.070 / 286.340$

$645.053 / 258.345$

$644.930 / 258.370$

$644.940 / 258.335$

$655.900 / 253.500$

$684.450 / 300.290$

$598.700 / 250.020$

$613.630 / 251.000$

$603.400 / 259.850$

$656.550 / 264.900$

$594.680 / 241.500$

$594.730 / 241.600$

$611.320 / 250.000$

$611.180 / 250.010$

$509.500 / 249.600$

$585.750 / 225.500$

$586.990 / 228.590$

$585,600 / 235.150$

$585.600 / 235.270$

$586.420 / 235.380$

$586.230 / 235.450$

$585.480 / 235.400$

$\mathbf{5 8 4 . 1 5 0 / 2 3 7 . 2 3 0}$

$584.070 / 237.170$

$569,020 / 233,730$

$578.400 / 238.800$

$588.650 / 237.860$

$585.980 / 238.290$

$582.600 / 240.120$

$587.380 / 240.120$

587.760239 .680

579.7601242 .0100

$578.290 / 242.470$

$578.050 / 242.310$

$578.490 / 242.110$

$578.240 / 242.050$

$579.200 / 243.320$

579.100243 .470

580.350245 .000

$581.550 / 244.250$

$582.650 / 245.830$

$579.200 / 246.370$

$580.610 / 247.540$

$581.930 / 248.050$

$574.490 / 247.200$

$572.560 / 250.840$

$574.800 / 248.200$

$571.650 / 253.820$

$571.300 / 256.250$

$569.680 / 256.550$

of section

$675.700 / 276.120$

677.440276 .530

$679.230 / 277.36$ )

682.480281 .100

682.000286 .160

$680.980 / 287.240$

$682.210 / 287.300$

$688.080 / 286.340$

$686.430 / 287.850$

$684.340 / 291.620$

$685.530 / 294.650$

$680.300 / 300.460$

$684.230 / 300.220$

$3.468 .500 / 5.305 .560$

$3.474 .370 / 5.303 .670$

$3.480 .430 / 5.310 .730$

$3.483 .060 / 5.313 .576$

$645.250 / 258.550$

$682.130 / 287.060$

$645.480 / 259.180$

$645.150 / 258.700$

$651.710 / 264.070$

$682.100 / 286.870$

$654.000 / 252.420$

$651.500 / 264.130$

$688,070 / 286.340$

$645.075 / 258.335$

$644.930 / 258.370$

$644.940 / 258.335$

$656.030 / 253.450$

$684.400 / 300.310$

$598.690 / 250.140$

$613.650 / 250.920$ $603.370 / 259.930$

656.5007264 .880

$594.670 / 241.510$

$594.800 / 241.680$

$611.410 / 249.850$

$611.070 / 250.160$

$599.720 / 249.620$

$585.900 / 226.330$

$587.040 / 228.450$

$585.580 / 235.180$

$585.580 / 235.320$

$586.230 / 235.450$

$586.3 \times 00 / 235.650$

$585.480 / 235.520$

$584.170 / 237.220$

$584.030 / 236.720$

$568.870 / 233.750$

$578.130 / 238.730$

$588.760 / 238.140$

$585.850 / 238360$

$582.900 / 239.820$

$587.450 / 239.820$

$587.700 / 239.660$

$580.090 / 242.070$

$578.270 / 242200$

$577.920 / 242.300$

$578.350 / 242.070$ 
Co-ordinates beginning of section

$569650 / 259.740$

$566.110 / 254,860$

$573.790 / 247.100$

$580.420 / 241.880$

$580.840 / 241.900$

$586.000 / 241.170$

$599.670 / 234.490$

599640235.200

$593.470 / 234.000$

$569.980 / 248.480$

$593.650 / 251.290$

$593.930 / 249.820$

$\$ 93.990 / 249.490$

$589.930 / 248.570$

$593.760 / 247.740$

$595.040 / 241.690$

$\$ 92.740 / 240.910$

$591.380 / 240.860$

$594.450 / 239.290$

$594.200 / 240.600$

$596.370 / 240.230$

$600.700 / 232.130$

$593.170 / 234.310$

$601.370 / 232.610$

$599.950 / 231.400$

$399.020 / 232.090$

$593.850 / 240.340$

$594.080 / 240.540$

$595.720 / 237.320$

$595.550 / 238.100$

$394.800 / 260.700$

$596,990 / 255.420$

$597.930 / 253,410$

$600.360 / 250.210$

$601.490 / 246.780$

$603.680 / 246.540$

602.130/252.760

$602.180 / 242.100$

$605.430 / 242.880$

$601.280 / 240.480$

$598.980 / 238.300$

$599.570 / 238.370$

$599.320 / 238.180$

$600.890 / 238.380$

$604.680 / 239.450$

$604.160 / 238.000$

$605.570 / 237.510$

$602.060 / 234.920$

$(602.230 / 234.800$

$603.990 / 232.230$

$602.680 / 231.700$

$585.950225,600$

$613.090 / 236.770$

$613,0802236,920$

$619.410 / 241.350$

$618.900 / 239.570$

$612.850 / 236.600$

$581.830 / 244.690$

$580.849 / 246.243$

632.790251 .725

$625.820 / 241.500$

$607.440 / 245.820$

$619.710 / 239.380$

$594.030 / 240.520$

$594.090 / 234.080$

$601.630 / 238.430$

$\mathbf{5 6 7 . 6 4 9 / 2 5 4 . 6 7 0}$

$567.897 / 253.184$

$567.100 / 256.570$

$604.530 / 253.070$

$385.850 / 225,750$
Co-ordinates end of section

$569.630 / 259.800$ $565.960 / 254.940$ $\mathbf{5 7 3 . 9 5 0 / 2 4 7 . 4 3 0}$ $580.500 / 241.830$ $581.150 / 242.120$ $585.950 / 241.220$ $599.750 / 234.370$ $599.620 / 235.240$ $593.530 / 234.030$ $569.980 / 248.480$ $593.980 / 251.230$ $593.990 / 249.620$ $593.520 / 249.470$ $589.950 / 248.810$ 593.890/247.420 $595.070 / 241.800$ $592.740 / 241.060$ $291.420 / 240.980$ $595.140 / 239.540$ $594.170 / 240.640$ $596.430 / 240.380$ $600.760 / 232.150$ $\mathbf{5 9 3 . 3 5 0 / 2 3 4 , 6 9 0}$ $601.370 / 232.600$ $600.020 / 231.210$ $599070 / 232.140$ $593.850 / 240.345$ $594.050 / 240.530$ $595.700 / 237.100$ $595.670 / 238.120$ $594.920 / 260,750$ $597.070 / 255.500$ $597.920 / 253.300$ $600.320 / 250.470$ $601.510 / 246.720$ $603.630 / 246.320$ $602.530 / 252.680$ $602.290 / 242.060$ $605.250 / 242.950$ $601.350 / 240.750$ $599.020 / 238.220$ $599.510 / 238.5000$ $599.390 / 238.130$ $600.490 / 238.200$ $604.620 / 239.330$ $604.200 / 238.300$ $605.570 / 237.320$ $602.170 / 234.880$ 602.320/234.770 $603.950 / 232.040$ 602.880/231.650 $585.970 / 225.800$ $613.130 / 236.850$ $613.080 / 236,980$ $619.331 / 241.230$ $618,900 / 239,590$ 612.840/236.650

$580.849 / 246.243$ $632.790 / 251.725$ $625.800 / 241.430$ $607.500 / 245,750$ 619.710239 .380 $594.030 / 240.530$ $594.090 / 234.080$ $601.710 / 238.500$ $567.649 / 254.670$ $567.897 / 253.184$ $567.100 / 256.570$ $604.510 / 253.080$ $385.860 / 225.900$

Tab. 1: Ccordinates of measured sections. The RG numbers with an asterisk are sections that have been partly or wholly measured on the rope. Sections printed in boldface are published here: Plates $16-44$. 
This proved later to be a grave miscorrelation that is perpetuated by some French authors to the present day. e.g. Cuauve et al. (1985).

GRESSLY (1838-41) carried out extensive mapping in Canton Solothurn and in adjacent areas. He collected fossils in large numbers for the first time in Switzerland. It occurred to him by close observation of the coral bioherms of the St-Ursanne Formation near La Caquerelle and the coeval fine-grained sediments of the basin further east that the vertical and lateral succession of sediments is not random. He introduced the concept of facies into the geologic literature and recognized some common facies patterns (sec Cross \& HoMEwood 1997). In spite of the great effort in mapping, fossil collecting, and practical use of his excellent new stratigraphic method, Gressix, in his own opinion, did not achieve a satisfactory correlation between sediments from shallow water and those of deeper marine origin. Basically, he retained the correlation by MERIAN (1821).

The progress of stratigraphical palaeontology as pioneered by OPPEL led to an important revision of MERLAN's correlation. OPPEL $(1856-58)$ introduced the biostratigraphical zone. He could prove with ammonites that the thick Renggeri Member and part of the Sornetan Member in the northwest thin out to the southeast and grade into what is now called the Schellenbrücke Bed (figs, 3 and 39 ). This is a ferriferous marly limestone with iron ooids which is on the average about $10 \mathrm{~cm}$ thick. OppeL cooperated with MorscH. One result of this was the definition of the Transversarium ammonite zone sensu lato (Oppel 1863, p. 165) that was published in its definitive form posthumously by WaAgen (Orpel \& WaAgen 1866). The Transversarium Zone is the oldest well-documented ammonite zone.

RoL.LeR (1888) mapped a large part of the Swiss Jura range and proposed a new correlation of the Oxfordian deposits. He correlated the Liesberg Member of the central Jura with the Birmenstorf Member of Canton Aargau (RoLLIER 1888. p. 87). He thought that the St-Ursanne Formation was the time equivalent of the Effingen and Geissberg Members (fig. 3). RoLLIER (1888) produced no evidence from ammonites of the shallow water realm to prove his assertion. Nevertheless, he reaffirmed his view in his publication of 1911 (fig. 54), and it remained unchallenged until 1967 when BoLLIGER \& BURRI proposed a new correlation.

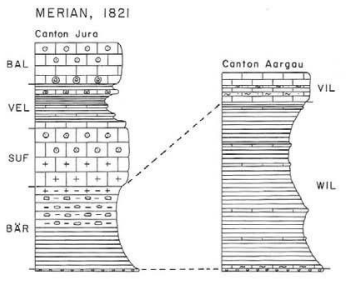

ROLLIER, 1888

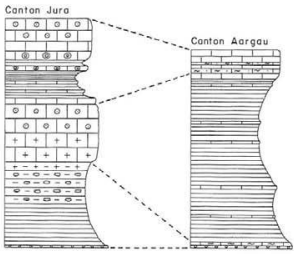

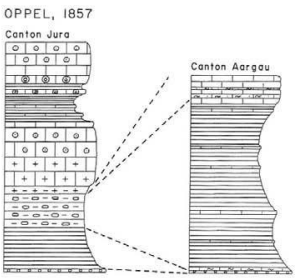

BOLLIGER \& BURRI, 1967

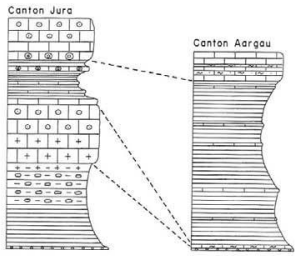

Fig. 3: Historical correlations within the Oxfordian of northern Switzerland.

BA1. Balsthal Formation BAR Bärschwil Formation SUF SI-Ursanne Formation
VEL Vellerat Formation VIL Villigen Formation WIL Wildegg Formation 
The significance of the important palacontological work by DE LoRIot in relation to RoLLIFR's correlation was not recognized by the stratigraphical workers of the time, because the systematics of the perisphinctids were then unresolved. In a short review, ArkeLl (1956, p. 95-96) threw some light on the stratigraphical implications of the ammonites published by $D E$ LoRJOL (1896) from the Sornetan Member of Liesberg by clearly stating that they are conspecific with some of the essential species of the English Plicatilis Zone. In the modern zonation. these ammonites indicate the Antecedens Subzone of the middle Transversarium Zone.

ZIEGLER (1962) studied the platform to basin transition of what are now the St-Ursanne and the Vellerat Formations (fig. 39). He did not question the correlation by ROLLIER (1888) of the St-Ursanne Formation with most of the Wildegg Formation (fig. 40). ZIEOLER (1962) paid special attention to the detrital quartz in the Röschenz Member (olim Natica Member). Some authors of the last century had already noted the oceurrence of beds with a high detrital quartz content in the Röschenz and Effingen Members. RoLlier (1898, p. 58) reported limestone bands in the Röschenz Member with sufficient fine-grained detrital quart/ that they could be worked for grindstones from near Damvant west of Porrentruy. ZIEGLER (1962. p. 26, 42) concluded from the good sorting of this quarts and the fine grain size that it might be of eolian origin.

BOLLIGER \& BURRI (1967) took the acolian origin of the quartz sand for granted and considered the vertical variation of the quartz content to be a reliable means of correlation between the platform and the basin. They arrived at a correlation of the Röschenz Member with the Effingen Member, and they consequently correlated the entire St-Ursanne Formation with only the thin Birmenstorf Member (see this paper, fig, 3).

GyGr (1969) studied the Oxfordian lithostratigraphy and ammonite biostratigraphy from Canton Solothurn in the west to the Danube River in the northeast. He found that the work by Wurtenberger \& Wütengerger (1866) in the Klettgau and Randen and by MoEscH (1867) in Canton Aargau was reljable. He finished his manuscript in June 1967, prior to the compietion and publication of the paper by BOLLiger \& BURE (1967) which was in fact published in January 1968 . These authors did not discuss whether the climate was dry enough to make aeolian transport of detrital quartz at the observed scale possible. The rough surface textures of the quartz grains they figured in 1970 are mainly the result of diagenetic etching (GrG 1969, p. 20), not aeolian frosting. BOLLIGER \& BURRI $(1967,1970)$ apparently did not recognize that the detrital quartz in the lower Effingen Member was concentrated by turbidites (GYGI et al.1998. fig. 10) and in the upper Effingen Member by storms (Grat 1986, fig. 7). Their correlation was plausible from the scdimentological point of view, but there were no ammonites nor other means of correlation to prove it.

A new tool for correlation was introduced to the Swiss Jura by Persoz \& Remane (1976) and by Persoz (1982). They used clay minerals for correlation, because detrital clay minerals have the advantage that they are ubiquitous through the whole succession. Clay minerals are present even in winnowed deposits like carbonate oolite. The authors concluded that the vertical variation in the distribution of clay minerals, particularly the variation in kaolinite, could be used for stratigraphic correlation from terrestrial to deeper marine environments. GYGi \& PERsoz (1986) refined this method by combining it with ammonitc biostratigraphy in the Oxfordian of Canton Aargau and of the central Jura. They first analyzed sections mineralogically in the basin (Canton Aargau) that are well calibrated biostratigraphically by thousands of ammonites. Then they correlated these sections using clay mineral marker horizons with others in the central Jura where few or no ammonites had been found. The few ammonites now known from the central Jura have since corroborated the mineralostratigraphic correlations (Groi, 1995). The papers by GyGi \& PERsoz (1986) and GvGr (1995) showed that the correlations by BOLLIGER \& BURRI (1967) were essentially correct. Other results were that the Hauptmumienbank Member of Ziegler (1956) was indeed a useful marker unit, and that the base of the Reuchenette Formation coincided with the Oxfordian-Kimmeridgian boundary as it was traditionally placed in the ammonite facies of Central Europe (e.g. CAR1ou et al. 1991a). Gra (1995) described and figured ammonites from Oxfordian and Kimmeridgian sediments of the shallow water realm in northwestern Switzerland.

\subsection{Aim and structure of this paper}

The principal aim of this paper is to present the most important Late Jurassic sections in the Central Jura that have been measured by the author since 1978. ZIEGLER (1956). ZIEGLER (1962) and BOLliger \& BurRı (1970) have already published some of these sections, but the thesis by ZIECLER (1962) was not printed in a periodical and is not easy to obtain. In the second main part of this paper the ammonites which are relevant for zonation and international correlation are presented. This work also aims to summarize all of the important results which have been published over the past 25 years in different periodicals by the author and his co-authors.

\subsection{Methods, classifications and terminology}

Much emphasis was placed on detailed measuring of stratigraphical sections in the field. Each measured section was given an individual running number. Every bed more than $5 \mathrm{~cm}$ thick was numbered separately in the sections, sampled and briefly described in the fieldbook. When a bed was thicker than $1 \mathrm{~m}$, several samples were taken at a vertical distance not exceeding $1 \mathrm{~m}$. Samples large enough to prepare thin sections or polished slabs were only taken from representative rocks. Each rock sample, polished slab or thin section has been ascribed a number prefixed by the letters Gy to show that they are part of the author's collection. Additional samples were taken where necessary during the preparation of the interpreted sections. Therefore the Gy-numbers are not always in order in the sections. When the beds are horizontal or only slightly inclined, it is often not possible to measure the complete section from ground level. In these cases, a light steel rope with a comfortable seat attached was used (fig. 4). This made it possible to work with both hands free for a whole day on a quarry face or a natural cliff. 
Only those samples that are kept in the Museum of Natural History Basel are recorded in the presented sections. The majority of the 3882 numbered samples or polished slabs are orientated 2338 of these were processed to thin-sections. One half of the surface of each of the the thin-sections was stained with a mixture of alizarine red and potassium hexacyanoferrate in order to identify the different kinds of carbonate using the method described by Dickson (1966). The several hundred polished slabs served to study stromatolites, oncolites and other large features that are too large to be easily seen in thin section.

One of the aims of this study was to collect and identify a sufficient number of ammonites for the full biostratigraphic calibration of the studied Upper Jurassic sediments. All well-preserved fossils were collected and are kept in the Museum of Natural History Basel. This served to characterize palaeoenvironments and mainly palaeodepth in the deep subtidal zone following Gvat (1986, fig.6). All the well-preserved ammonites have an individual number preceded by a J. Only a limited number of fossils were found in natural outcrops or in quarries. Therefore it was necessary to cxcavate fossils systcmatically (fig.5). After an excavation was opened up, where possible with a bulldozer or a mechanical shovel, the section was carefully measured and the beds were numbered. Then the beds were thoroughly searched for fossils. A jack hammer served to break up the beds before they were worked with the geological hammer. An Atlas Copco "Cobra" machine driven by a combustion engine was preferred for breaking up the beds because it could also be used in places inaccessible to vehicles. This hammer may be switched to a drilling machine to produce boreholes for blasting in order to remove hard overburden above the fossil beds. Blasting was sometimes necessary when excavations had to be done completely by hand as for instance on steep, forested slopes that were inaccessible to a mechanical shovel or a bulldozer.

A new laboratory was installed in the Museum of Natural History Basel for the preparation of fossils. About 5400 well-preserved ammonites had to be worked within a reasonable time span. The first step was to cut off as much rock as possible from the ammonite with a diamond saw. Tools driven by compressed air proved to be the most efficient and also the most precise for further processing. Very large specimens were first worked on an open sand-filled case with a large flat chisel held with both hands, then with a small flat chisel and finally with an engraving pen. Smaller specimens were prepared in a closed chamber (fig. 6) with a little flat chisel that can be held with one hand in order to uncover the ammonite to within about two millimeters from the surface. The final preparation was done with an Atlas Copco engraving pen which performs 450 small strokes per second. The exhaust of the tool aims at the point of the chisel so that dust and rock particles are constantly blown off. This makes precise working possible. Dust is removed from the chamber with vacuum.

The classification by Dunfam (1962) served to deseribe carbonate rocks in the field. The depositional textures according to this author are also recorded in the lithostratigraphical sections presented. The extended classification of depositional textures according to EMBry * KLovas (1971, fig. 2) was used when necessary. Carbonate rocks studied in thin section are named after

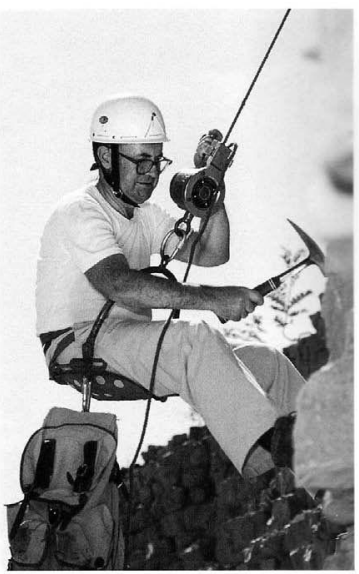

Fig. 4: Measuring a section on a light steel rope lined with nylon fabric. The steel seat is held steady by a clamp with wooden brake-shoes that may be fastened with a serew (lever held by the left hand). When descending, an automatic brake operating with the centrifugal force regulates the sinking speed to $1 \mathrm{ml}$ per second. This safety brake is in the circular casing beside the face. With this device it was possible to work with two free hands for measuring, taking samples and writing. When measuring long sections, a very high frequency (VHF) radio was used to dictate the text to be written into the fieldbook to S. Gygi (my wife).

Folk (1962). Beds dominated by sedentary organisms are called biostrome (CUMINGs, 1932,p. 334). If beds with sedentary organisms swell to dome-like structures that had a primary elevation above the sediment around, they are ealled bioherm (Cumings \& Shrock, 1928). Lowenstam (1950, p.433) recommended that the term reef be used only in cases whete the sedentary organisms build a rigid, wave-resistant frame in a structure that rises above the sediment around it. Other geological terms are used according to the "Glossary of Geology" by BaIES \& JACKSON (1980).

The following abbreviations are used in the lithostratigraphic sections (pls. 16-44):

RS: rock sample

PS: polished slab

TS: thin section 


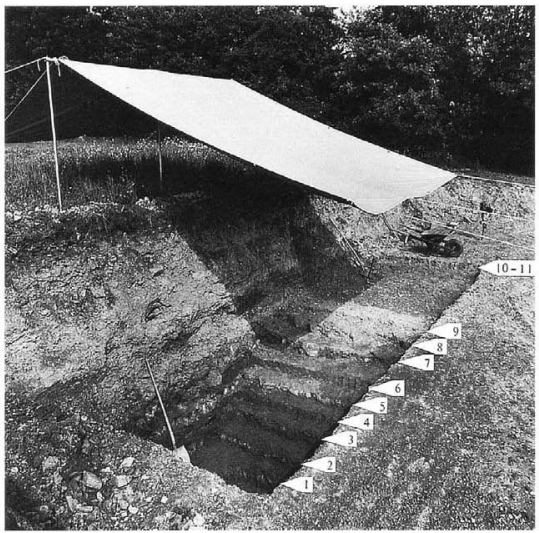

Fig.5: Excavation RG 208 on Brunnrain near Ueken $A G$ north of the Herznach iron mine. Beds no. 1-5 are of Callovian age. whereas beds $6-11$ are of

Oxfordian age. Beds 12-18 (see GyGl 1977. pl.11) were excavated with a bulldozer as overburden. because they contain few fossils Beds 1-11 were worked by hand. The hand-excavated beds had a surface of 120 square meters They were worked in three parallel strips.

The sequence stratigraphical interpretation from Gygi et al. (1998) is shown in the sections of pl. 16-44. O1 to O8 refers to the eight Oxfordian sequence boundaries; $\mathrm{K} 1$ to $\mathrm{K} 4$ to the Kimmeridgian sequence boundaries.

The two letters used after the name of a village or a town are the official abbreviation for the canton that the settlement be longs to

MNHB: Museum of Natural History Basel

Fig. 6: Preparation of a smaller ammonite in a closed chamber with in ternal lighting. The compressed air is fed through an automatic oil lu brication device (on the outside of the chamber) to the engraving pen. Used air and dust are removed from the chamber by vacuum through the thick hose in the center.

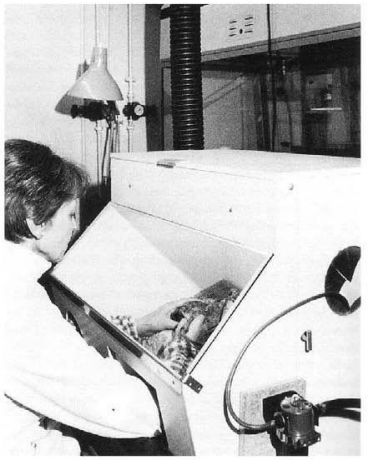




\section{Facies analysis}

The lithostratigraphical units cited in the following text and their time-stratigraphical framework are listed in fig.40. The field relations of the units are represented in fig. 39 .

\section{$2.1 \quad$ Lithofacies}

\subsubsection{Basinal facies}

\section{I.I.I Basinal argillaceous mudstone (marl)}

The best example of basinal argillaceous mudstone in the central Jura is the Renggeri Member. This rock consists mainly of clay minerals and calcium carbonate. According to Pfrunder \& WICKERT $(1970$, tab. 1) the carbonate content of this argillaccous mudstone is between 27 and $33 \%$ near Liesberg BL. It is then, using the classification of PETUuOHN (1957, fig. 99), a clayey marl. The blue-grey colour of the rock is probably caused by very fine-grained pyrite which is indicated by the relatively high iron content (see PrRUNder \& WICKERT 1970, tab. 1). This clayey marl is homogenous because of thorough bioturbation. Burrows filled with iron sulfide are very common (fig. 7). Lamination has never been observed.

The Sornetan Member consists of argillaceous mudstone with bands of limestone concretions and continuous beds of marly limestone. The total carbonate content of the member

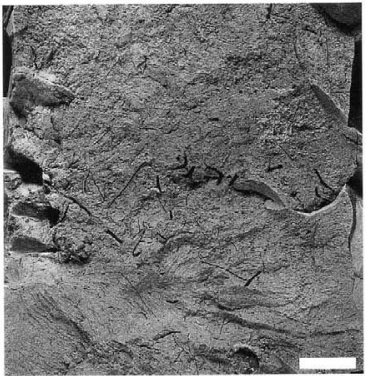

Fig. 7: Clayey marl of the Rengeri Memher with burrows filled with iron sulfide. Section RG 280. Liesberg BL, bed 7.2.3 $\mathrm{m}$ above the base. Sample Gy 3257. Scale bar is $2 \mathrm{~cm}$.

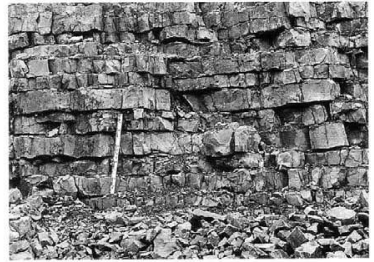

Fig. 8: Basinal lime mudstone of the Gerstenhubel Beds in the lower Effingen Member. Quarry north of Monthal AG. Scale bar is $1 \mathrm{~m}$.

near Liesberg is around $54 \%$ (Prrunder \& Wickert. 1970. tab. 1). The volume of limestone concretions and bands may be estimated to be about $15 \%$ of the whole rock unit (see pl. 31 ). Therefore, the mudstone matrix of the Sornetan Member has a carbonate content of less than $50 \%$ near Liesberg. The average content of detrital quartz of the whole rock unit must be less than $2 \%$ judging from thin sections of carbonate bands and eoncretions.

The Effingen Member is a complicated suceession of argillaceous mudstones interbedded with variably spaced beds with a higher carbonate content (Gxo1 1969, pl.17, section 37). The lowest carbonate content was recorded in the lower part of the member and is less than $40 \%$. The average carbonate content of the argillaceous mudstone in the Effingen Member is more than $50 \%$, mainly in the upper part of the member. Lime mud then predominated in the sediment of the Effingen Member over argillaceous mud.

\subsubsection{Basinal lime mudstone}

All the basinal limestones are mudstones which grade into peloidal wackestones or, in some cases, even to peloidal grainstones Grai (1969, p. 39-42) described some of these rocks in detail and figured them. Coccoliths are rare, if they are present, they are not or only slightly recrystallized. Therefore, there was probably only slight recrystallization of the rock after transformation of the lime mud to low magnesian calcite, and coccolithophorid micellae cannot have been a major constituent. Fossil detritus recognizeable under the petrographic microscope only forms about $10 \%$ of the rock. Study of the grain-size fraction of below 25 microns under the transmission electron microscope revealed that less than $5 \%$ of the particles were definitely fossil detritus. More than $80 \%$ of the rock is then micrite 
of unknown origin. The sediment may be transformed to faecal pellets to the packstone concentration in some places (Grol 1969. pl. 13. fig. 48). Basinal lime mudstones (calcilutites) are always well-bedded (fig 8 ) into layers less than $1 \mathrm{~m}$ thick.

\subsubsection{Basinal iron oolite}

The oldest Oxfordian bed in northwestern Switzerland is a $20 \mathrm{~cm}$ to $30 \mathrm{~cm}$ thick clayey marl with some iron ooids. This bed is always present below the Renggeri Member and although thin, it is laterally continuous. It is the uppermost bed of the Herznach Formation (see definition below). The content of iron ooids deereases from about $5 \%$ at the base to zero at the top of the bed where the facies of the Renggeri Member begins.

The Schellenbrücke Bed is another thin and widespread basinal iron oolite within the Herznach Formation. The mode of formation of this bed has been discussed in detail by Grol (1981). The average content of iron ooids is only about $10 \%$ (GYG1 1981, p. 239). The iron ooids are limonitic, chamositic or they have cortices of chamosite alternating with cortices of limonite. The matrix is a ferriferous lime mudstone (fig. 9). The bed is condensed, sometimes to the extent that only the limonitic/chamositic crust at its top is present (fig. 40). The bed occurs between the toe of the submarine bank of the Bärschwil Formation where the water depth is interpreted to have been about $80 \mathrm{~m}$ and grades in the distal direction into the thin Glaukonitsandmergel Bed where the water depth is calculated to have been around $100 \mathrm{~m}$ (GYar 1981, fig. 4). An orebody of iron colite which was mined until the beginning of this century exists in the uppermost Sornetan Member ncar Chamesol and Montécheroux (France), $25 \mathrm{~km}$ west of St-Ursanne. Near Bure $\mathrm{JU}$ in section RG 456 there is a $50 \mathrm{~cm}$ thick marly limestone that contains $10 \%$ of limonitic iron ooids $3 \mathrm{~m}$ below the top of the Sornetan Member. No iron ooids have ever been found in the more distal part of the Sornetan Member that is coeval with the Schellenbrücke Bed and the overlying condensed bed at the base of the Birmenstorf Member that in some outcrops con-

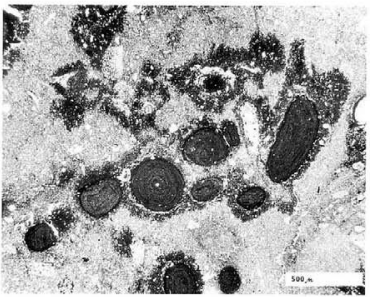

Fig. 9: Goethitic iron ooids in biomicritic matrix. Schellenbracke Bed. early Oxfordian. Cordatum Subchron, Schellenbrücke near Küttigen AG.TS Gy 2712, section RG 32, bed 3 (see GYG1 1969, pl. 17). tains chamositic iron ooids. It is therefore impossible that the iron ocids of the Schellenbrúcke Bed or the condensed bed at the base of the Birmenstorf Member were transported from shallower water to the basin. The Schellenbrücke Bed contains a rich and diverse ammonite fauna indicating a depth of deposition of between 80 and $100 \mathrm{~m}$. Lenses of basinal iron oolite-rich clayey marl exist near Herznach and Gansingen below the Schellenbrucke Bed (section RG 208, bed 6. GyG 1977. pl. 11, fig.2, excavation on Brunnrain, and section RG 60, bed 3, GYGı 1966, fig. 1, Eisengraben, respectively).

\subsection{J.4 Basinal spongolite}

The most widespread basinal spongolite with wholly fossilized siliceous sponges is the Birmenstorf Member. This is deseribed in section 2.2 Biofacies. Siliceous sponges may form as much as $30 \%$ of the rock volume in this member (GrG 1969, pl. 2, fig, 6). The matrix is lime mudstone or marl. Siliceous sponges can also be abundant in the lowermost Effingen Member (GYGl 1969. $\mathrm{pl}$.19) and in the distal part of the Crenularis Member near Mellikon (GyGl 1969, pl.6. fig. 23, GyGl 1992, figs. 23-25). The matrix of the sponge bioherms in the Crenularis Member is lime mudstone. Siliceous sponges are less abundant in the Crenularis Member than in the Birmenstorf Member. The lowermost bed of the Pichoux Formation is, in some sections, a spongolite. At Péry BE it even contains small sponge bioherms with an elevation of $1 \mathrm{~m}$ above the surrounding sediment. Sponge bioherms are also found in the Hornbuck Member of Canton Schaffhausen and in the Knollen Bed near Küssaburg in southern Germany north of Zurzach (GyGr 1969, pl, 19), and at Immendingen and Mohringen in southern Germany. Siliceous sponges are abundant in the uppermost Letzi and Wangental Members and again in the lower Baden Member. The massive part of the upper Wettingen Member is a basinal spongolite, but occasionally giant sponges are found in the well-bedded lower Wettingen Member at Mellikon AG.

\subsubsection{Basinaloncolite}

Late Jurassic oncolites from the upper slope and from the basin in northern Switzerland were described by GYGI (1992). The most remarkable beds with basinal oncoids are the Mumienmergel and the Mumienkalk Beds of the Klettgat and Randen in Canton Schafthausen. The oncoids of the Mumienkalk Bed are well-rounded and have a maximum diameter of $3.5 \mathrm{~cm}$. They contain abundant glauconite and are slightly ferriferous (GyGl et al. 1979, fig. 14a, Grat 1992, fig. 35). The matrix is glauconitic lime mudstone. The depth of deposition of the Mumienkalk Bed was estimated by Gral et al. $(1979$, p. 946) at about $100 \mathrm{~m}$. GyG (1986, fig. 2) rated this depth at well over $100 \mathrm{~m}$, because there are no signs that this bed was above storm wave base, Gygt et al. (1979, p. 942-946) described the Mumienkalk Bed in detail and discussed its mode of formation.

The Mumienmergel Bed below the Mumienkalk Bed has a matrix of glauconitic marl. This marl contains carbonate internal moulds of ammonites with a thick oncolitic crust. The ammonites are up to $25 \mathrm{~cm}$ in diameter. The sediments infilling the ammonite chambers prove that the ammonites have been overturned during fossilization. Some of the ammonite moulds are fractured. It can be excluded that currents overturned and frac- 


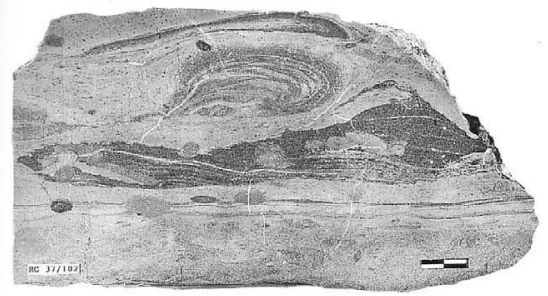

Fig. 10: Submarine debris flow deposit with plastically deformed clasts of pelsparite with detrital quartz, partially burrowed. Polished slab of marl-limestone. bed no 102 of section RG 37 upper Effingen Mcmber. Auenstein AG. Refigured from Gxal \&: Persoz (1986). Scale bar is $2 \mathrm{~cm}$

tured the moulds Currents strong enough to do this would have abraded the surface of the moulds and removed the argillaceous matrix. This is not the case. Gygl $(1969$, p. 105) assumed that animals in the search of food overturned the moulds, as Recent hogfish in the tropical West Atlantic overturn nodules of red algae (BOHLKE \& CHAPLIN 1970).

Oncoids that grew on the upper slope occur in the lime mudstones of the lower Baden Member in the southern quarry of Löchli at Däniken SO and in the section RG 28, bed 47 at Halden east of Schonenwerd SO (Grat 1992, fig. 17). The oncoids have a diameter of up to $15 \mathrm{~mm}$ and contain glauconite. Glauconitic oncoids with a maximum diameter of $7 \mathrm{~mm}$ were found in the upper Crenularis Member which is exposed in the quarry adjacent to the public swimming pool near Auenstein AG. These oncoids occur in a matrix of lime mudstone (section RG 34, bed 25, samples Gy 587 and Gy 588, unpublished). The glauconitic oncoids found elsewhere in the upper Crenularis Member are even smaller (Grol 1969, pl.5, fig. 21).

\subsubsection{Glanconitic rocks}

Distinct glauconite pellets with a glossy surface are found only in sediments interpreted to have been deposited in water depths greater than $100 \mathrm{~m}$ (GYGi 1981, 1986). Abraded glauconite pellets are found in well-sorted, sandy turbidites where they have the same grain size as the detrital quartz. Glauconitic infillings of algal tubes or diffuse glauconitic impregnations in bioclasts occur in sediments interpreted to have been deposited in water depths of less than $100 \mathrm{~m}$. Glauconitic impregnations are relatively easy to see with a hand lens, but they are only visible with difficulty in thin section with the petrographic microscope.

Pellets of glauconite occur within the basinal area for the first time in the Lamberti Subchron. The pellets are found within lenses of ferriferous marl with iron ooids near Gächlingen (section RG 81b, bed 10) and near Siblingen (section RG 212, at the top of bed 4, in GyGl, 1977, pl.11). According to Gror (1981). these lenses must have been deposited at a depth of about $100 \mathrm{~m}$ which is apparently the greatest depth at which iron ooids can be formed by being rolled. The greatest concentration of glau- conite was found in the Glaukonitsandmergel Bed of the Klettgau and Randen (fig. 40). Up to $30 \%$ of the volume of this rock is glauconite pellets. At least part of this glauconite is probably derived from the transformation of biotite, because some fresh biotite grains were found (Grai \& McDoweL. 1970. p.115). Glauconite is also abundant in the Mumienmergel and Mumienkalk Beds as well as in the glauconitic marl above the Mumienkalk Bed (fig. 40). The Knollen Bed sometimescontains abundant glauconite north of the Rhine.

In Canton Aargau clearly delimitcd glauconite pellets are present in the Birmenstorf Member. Glauconitization of biotite was demonstrated in one case in a sample from the condensed bed at the base of the Birmenstorf Member (section RG 73 in the Berchenwald near Dangstetten, southern Germany, bed 5. see Gval 1969, pl.3, fig.9). The glauconite of the Crenularis Member (fig, 40) oocurs mainly as a filling of algal tubes and an impregnation in small oncoids. The mineral is rare in the Knollen Bed (fig, 40). It sometimes occurs in the uppermost Letzi Member. The marly limestone of the lower Baden Member (fig. 40) contains glauconite pellets and glauconitic coatings of fossils.

In the West, glauconite pellets are often abundant in the lowermost bed of the Pichoux Formation (fig. 40). Faint and diffuse green impregnations which are probably glauconite were found in section RG 276 at Mont Chemin near Courrendlin $J$ in bed 15, a biopelmicrite; thin section Gy 6336, of the Vorbourg Member. This is unusual, because the Vorbourg Member was deposited in very shallow water, partially even in the intertidal zone. Authigenic glauconite normally occurs only in sediments from decper water.

\subsubsection{Facies of the carbonate platform slope}

The average slope of the Pichoux Formation can be calculated to be $0.5^{\circ}$, when the decompaction and the differential subsidence of the basement under different sediment loads are taken into acount (see Gygt 1986, fig. 3). 


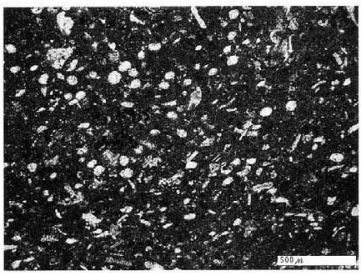

Fig. 11: Spiculite of the lower Pichoux Formation, favine southeast of La Kohlberg farm. Vermes IU. TS Gy 7582, section RG 406. bed 2 (pl.37).

\subsubsection{Debris flows}

Submarine debris flows were found mainly in the Effingen Member (Groi 1969, pl. 4, fig. 13, Grgl \& Persoz 1986, fig. 3, refigured here in fig. 10, GyGi \& Persoz 1987, fig .5), but they also occur in the distal part of the uppermost Effingen Member near Rekingen AG (section RG 68, bed 53, sample Gy 1409, Grai 1969,pl. 19, fig. 1). The debris flows are often associated with in traformational truncation surfaces (GYgl \& Persoz 1986, fig. 2). The flows are small-scale and local. The greatest depositional slope in parts of the Effingen Member must have been on average less than $1^{\circ}$ since the proximal part of the member directly overlies the Pichoux Formation (Gygl \& Pensoz 1986, pl.1). This is thought to be insufficient for the formation of debris flows, so it is postulated that the angle of the slope may have been locally augmented by growth faults (Groi 1986, fig 3D). A synsedimentary fault may be seen in GyG \& PERSOz (1986, fig. 2). However, Muluins \& Neumani (1979, p.181) surmised the presence of debris flows on the slope off the northern margin of the Great Bahama Bank where the average angle of the slope is only $1.5^{\circ}$ and where there are predominantly muddy deposits like pelagic carbonate oozes and muddy slope breccia (p. 182).

\subsubsection{Spiculise}

Spiculite, a lime mudstone with very abundant sponge spicula, is uncommon. Spiculites are present in the Sornetan Member and mainly in the Pichoux Formation. However, spicula may be common even in shallow-water coral biostromes (GYGI 1969. pl. 7. fig. 29). The spiculite figured here (fig. 11) from the section RG 406 near Vermes JU, bed 2 (pl. 37), is from the lower Pichoux Formation. It contains about $10 \%$ sponge spicula in a micritic groundmass.

\subsubsection{Facies of the carbonate platform margin}

\subsubsection{Coral bioherms}

The coral bioherms of the platform margin grew within the distal part of the oolite shoals that rim the platform and also off the platform margin in somewhat deeper water, within the carbonate mud of the uppermost slope. The bioherms are typically mud mounds which had a slight relief above the sediment surrounding them. The coral content may be as low as $10 \%$. The bioherms all appear to be isolated, they were nowhere observed to coalesce into a barrier reef (see BOLLIGER \& BURRI 1970, pL.1, fig. 1). Some of the bioherms weather out and form topographical features with steep sides. The steep clifts are formed by differential erosion between the well-cemented bioherm and the more friable sediment around it. The steep, eroded sides of the bioherms are not to be confused with the original relief which was probably very slight and of low angle. The bioherms that formed at this Jurassic platform margin are very different from Recent platform margin reefs (e.g James \& GinsBurg 1979). The platform slope in the Late Jurassic of northern Switzerland had an angle of only about half a degrec. This greatly reduced water circulation and the supply of food and oxygen to the bioherms. This might be the cause of the relatively weak development of the Jurassic platform margin bioherms.

The typical facies from the lower part of a coral bioherm is figured as a polished slab in fig. 12. The slab is from section RG 21 , bed 35 in the quarry on Mt. Born near Olten SO (GyGl 1969. pl. 18). The corals, which probably belong mainly to the genus Microsolena, are dish-shaped and make up about $10 \%$ of the rock volume. They are bored by the bivalve Lithophaga. The corals are partly dissolved and the cavities are filled with coarse-grained sparite or fragments of the encasing micrite. On top of the corals are faintly visible columnar stromatolites. The micritic groundmass was probably cemented early, or else it would not have fractured when entering the cavities in the partly dissolved corals. A thin-section of the same bed is figured in Gral (1969, pl. 9, fig. 35)

\subsubsection{Oolite bars}

The rim of the platforms of the upper St-Ursanne Formation, the Günsberg Formation and the Balsthal Formation is formed by oolite bars. Part of these bars is cross-bedded, for instance bed 162 in the Günsberg Formation of section RG 307 near Péry or beds 1 to 3 in the lower Balsthal Formation of section RG 20 near Hägendorf SO. Such a cross-bedded oosparite from the Steinebach Member was described ( $p .35$ ) and figured in detail (pl. 8, figs 32 and 33, pl. 9, figs. 34 and 36) by GyGi (1969).

\section{2,1.4 Facies of the lagoon}

\subsubsection{Tidal delas}

The Steinebach Member in section RG 307 near Péry BE is the delta of a tidal channel emptying into the lagoon. The lowest bed number 193 (see pl.22) is $2.4 \mathrm{~m}$ thick and had an internal depositional dip of $20^{\circ}$ towards northnortheast. A thin-section from this bed (Gy 5467) is an oomicrite to oosparite with an average of about $75 \%$ of primary micritic cement. In the mixed zones which contain primary micritic and secondary sparitic ce- 
Fig. 12: Polished slab from the base of a coral bioherm of the platform margin of the Balsthal Formation. Platc-shaped colonies of mainly Microsolena in a micritic groundmase On top of the corals are columnar stromatolites. The eorals are bored by the bivalve Lithophaga. PS Gv 4903 from section RG 21 in the quarry on Mt Born near Oiten SO, bed 35. Olten Member, Gyal (1969, pl. 18). Scale bar is $2 \mathrm{~cm}$.

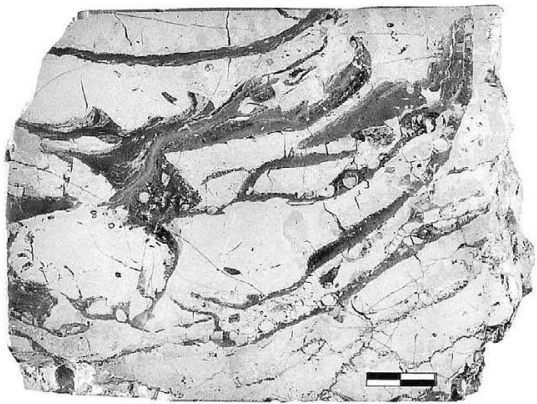

ment the lime mud of the primary cement is found in geopetal cavities (fig. 13). The middle bed, number 194, is an oolitic packstone $1.4 \mathrm{~m}$ thick that had an internal depositional dip of $10^{\circ}$ towards north-northeast. The upper bed, number 195 , is $1.9 \mathrm{~m}$ thick and had a depositional dip of $20^{\circ}$ towards west-northwest. It is an colitic to fine-oncolithic packstone and partly even a wackestone although the intermittent tidal currents during its deposition must have been rather strong. Large burrows with a diameter of 2 to $3 \mathrm{~cm}$ penetrate up to $30 \mathrm{~cm}$ down from the upper bedding plane. The bedding plane is hummocky and covered with a limonitic crust that indicates an early cemented and mineralized hardground.

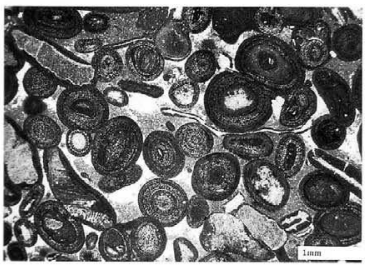

Fie. 13: Oomicrite with geopetal interstices filled with calcite spar, Steinebach Member. Pery BE. TS Gy 5467, section RG 307, bed 193 (pl. 22)

\subsubsection{Oncolite}

Some of the best examples of lagoonal oncolite are to be found in the Hauptmumienbank Member of the Vellerat Formation. The oncoids of the Hauptmumienbank Member grew to a diameter in excess of $4 \mathrm{~cm}$ (fig. 14) and were embedded in lime mud indicating a normally quiet depositional environment. The largest oncoids occur in the central belt of the elongate lagoon as for instance near Soyhières JU (see fig. 7 in GvG 1990c). Towards the platform margin, the micritic matrix between the large oncoids becomes increasingly oolitic, and the size and the abundance of the oncoids diminish. The size and the abundance of the oncoids also decrease in the proximal direction, and there the core of the oncoids often contains calcite pseudomorphs after gypsum (GyG \& Persoz 1987, fig. 2C). Algal filaments of different species of Girvanella and occasional small thalli of an undescribed species of Bacinella Raboicic occur in the crust of the oncoids of the Hauptmumienbank Member. The core of these oncoids is most often a small bioclast. The oncoids were lithified during growth. Evidence for this are common boring bivalves of the genus Lithophaga that are found within the oncoids. GASCHE (1956) described and figured these oncoids for the first time. ZIFGLER (1956, p. 46) discussed their environment of formation and concluded that the oncoids grew in the same place as the lime mud that forms the matrix was deposited. ZIEGLER (1956, p. 43) estimated the minimum areal extent of the algal biostrome of the Hauptmumienbank Member at more than $2000 \mathrm{~km}^{2}$.

The oldest Oxfordian oncolites occur in the lower St-Ursanne Formation. This is the Caquerelle Pisolite of ZIEGLER (1962, p. 18). The typical facies of this unit is a well winnowed rudstone with oncoids of a diameter from about $0.5 \mathrm{~mm}$ to $1 \mathrm{~cm}$. The best examples of this unit were found in the sections RG 338 


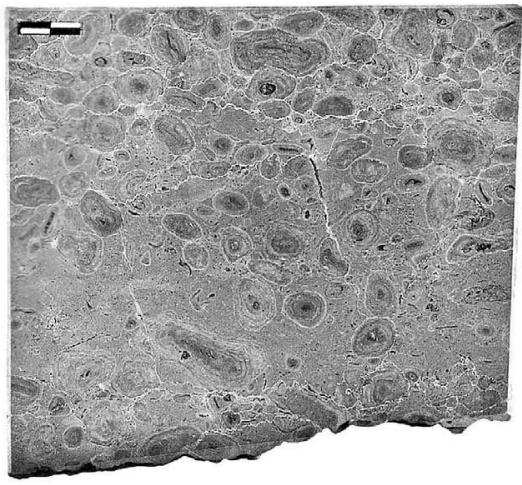

Fig. 14: Oncoids in a biomicritic groundmass. Polished slab cut perpendicularly to the bedding planes, PS Gy 4204, Hauptmumienbank Member, section RG 363 (unpublished), En Goulat near Soyhieres JU, bed 47 . Scale bar is $2 \mathrm{~cm}$.

at Còte du Frêne near Asuel JU, bed 90, PS Gy 3899, TS Gy 5891. and in the section RG 397 in the gorge west of the Schlossfelsen near Klcinlützel SO, bed 27. PS Gy 4536. TS Gy 6492. These oncoids have not been studied by a specialist. PÜMPIN (1965,p. 817) thought he recognized Girvanella pisolithica WETHERED in the crusis as well as encrusting foraminifera of the genus Nubeculinell $a$ and illustrated the unit in two figures (PúMPIN 1965, figs 6 and 7). There are patches with abundant $2 \mathrm{~cm}$ sizc oncoids in the section RG 336, bed 4, along the road from St-Ursanne J to the railway station: these are enclosed in a bioarenitic grainstone with hermatypic corals. Another oncolite with a lime mud matrix occurs locally in the upper St-Ursanne Formation in a quarry at the western end of the Landskron range near Leymen F (section RG 292, bed 12h. PS Gy 3295, TS Gy 5272). This oncolite is also mentioned by FisCHER ( 1965 a, p. 22).

The oncolites of the Günsberg Formation are found mainly near Péry BE in the quarry of La Charuque (section RG 435 . bed 9a, PS Gy 5059. TS Gy 7242). This is the Grüne Mumienbank of ZIEGLER (1956). The oncoids are spherical to lobate and are embedded in lime mudstone. They grew to a diameter of $5 \mathrm{~cm}$ (Gvol 1992, figs. 14 and 15). Other occurrences are at Peute Combe south of Grandval BE, section RG 357, bed 25 a. PS Gy 4140,TS Gy 6101, at Roches du Droit north of Crémines BE, section RG 417, bed 45, PS Gy 4833, TS Gy 6766 , and at Băchlen near Seehof BE, section RG 419 , bed 68, PS Gy 4870 , TS Gy 6802 (all the three sections unpublished). These oncolites were probably all formed at the same time.

The oldest oncolites of the Vellerat Formation are at differ- ent levels of the Vorbourg Member, for instance in section RG 320 at Montépoirgeat near Undervelier JU, bed 18, PS Gy 3674 , TS Gy 5674, or on Mont Chemin near Courrendlin JU, section RG 376, bed 14, PS Gy 4372. TS Gy 6335, above the Durtmattengraben near Wolschwiller F, section RG 394, bed 4. PS Gy 4513. TS Gy 6468, and on the Schutzenebnetchopf near Kleinlützel SO, locality RG 396, PS Gy 4532, TS Gy 6487.

The oncolites of the younger Roschenz Member within the Vellerat Formation are also to be found at various levels, for instance in the beds $17,28,31$ and 53 of section RG 300 at Eichlenberg near Zullwil SO. Particularly remarkable are the oncoids of bed 14 in the neighbouring section RG 304 at Fehren SO which reach a diameter of $6 \mathrm{~cm}$ (PS Gy 3411, TS Gy 5409). Other oncolites within the Röschenz Member are found near Souboz BE (section RG 312, bed 42), Undervelier JU (section RG 320, bed 58), Soulce JU (section RG 321, bed 19) and Chat tillon JU (section RG 368 , bed 80).

The oncolites of the Balsthal Formation are almost all in the Laufen Member. Oncolites are very common in this member. The oncoids can be embedded in lime mud as in bed 201 of section RG 307 near Péry BE (pl.22). This unit is very similar to the Hauptmumienbank Member, but the evidence from mineral stratigraphy (GYGl \& Pensoz 1986) and sequence stratigraphy (GYGt et al. 1998) indicates that it is younger. The oncoids of the Laufen Member can grow large even if they are embedded in packstone like in bed 7b of section RG 436 in Horngraben near Acdermannsdorf SO (PS Gy 5082. TS Gy 7260, unpublished). An undescribed species of the alga Bacinella is abundant in 
Fig. 15: Fine-graincd peloidal. sandy quartz siltstone, Röschenz Member. gorge northeasi of La Providence farm, Corban JU, TS Gy 6578 , section RG 400 , hed 50 (pl. 35)

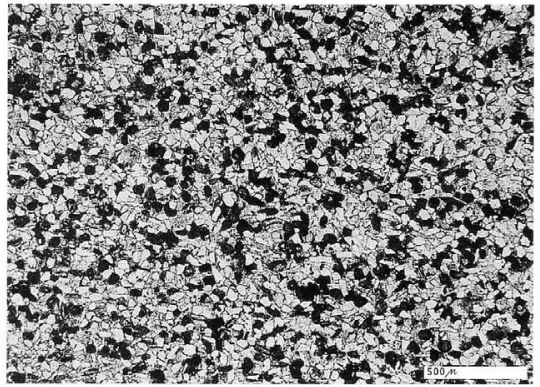

these oncoids. The species was figured under the name Bacinella irregularis RADoIcic by BOLLIGER \& BURRI (1970,pL.9. fig. 3). The Verena Member rarely contains oncolites. One occurs in bed $94 a$ of the section RG 320 at Montépoirgeat near Undervelier JU (PS Gy 3707. TS Gy 5711, unpublished). The other known occurrence was mentioned by Fischer (1965a, p. 22).

In the Courgenay Formation, only a single oncolite was encountered in the La May Member northwest of La Seigne Dessus near St-Ursanne JU in bed 10 of the section RG 326 (PS Gy 3776 , TS Gy 5774).

\section{$2,1.4 .3$ Coral bioherms}

The coral bioherms of the lagoon differ from the ones at the platform margin in that they are much more densely colonized by corals. Massive and thickly branching coral colonies make up as much as $50 \%$ of the volume of a coral bioherm in the quarry of St-Ursanne (bed 18 of section RG 336). The matrix of the reef core is micritic, but nevertheless this may be a true reef. One of these patch reefs near St-Ursanne was figured by Gris (1986, fig. 5). The primary relief of the reefs and the slope of the reef detritus aprons was very subdued (see PüMPiN 1965. fig. 14).

\subsubsection{Sandy quartz siltstones}

As Bol.LIGER * BURRI (1967) have pointed out, detrital quartz and some feldspar are abundant in the Vellerat and in the Wildegg Formations and, more specifically, in the Röschenz and in the Effingen Members. It is interesting to note that there is little detrital quartz in the argillaceous Bure Member of the upper Vellerat Formation. There is obviously no simple relation between the clay mincral content and the detrital quarts content in these sediments. Detrital quartz and feldspar may make up more than $50 \%$ of the rock volume in marls and limestones of the Röschenz Member. The quartzose limestones of this member are partly laminated and partly massive. ZiEGLer (1962, p.26 and 42) considered that acolian sedimentation of this quartz was a possibility because of its good sorting BotLIGER \& BURRI (1970. p. 19) stressed that the detrital quartz and feldspar were transported by the wind. No sedimentary structures indicative of wind transport have ever been observed in supratidal sediments of the Röschenz Member. Evaporites are entirely absent in this member. Instead, limnic ostracods, lignite and gyrogonites of characean algae indicate the presence of fresh water pools or swamps and thus a humid climate (GYGI 1986, p. 486). GYGI (1986. p. 487) concluded that the ample supply of terrigenous sediment that led to the deposition of the Róschenz and Effingen Members was indicative of a relatively wet climate. Water transportation of the bulk of the terrigenous sediment must therefore be assumed, but aeolian transportation of a small quantity of detrital quartz cannot be ruled out. A large amount of clay minerals must have bypassed the site of deposition of the Roschenz Member judging from the much greater thickness of the argillaceous Effingen Member.

Bed 50 of section RG 400 (pl. 35) which is in the small gorge northeast of the farm La Providence near Corban JU is a sandy quartz siltstone. The bed is $0.35 \mathrm{~m}$ thick and is laminated in the lower part. The constituent particles are detrital quartz and feldspar as well as carbonate micritic peloids (fig. 15). The peloids are well rounded and have sizes between 40 and $70 \mathrm{mi}$ crons. They make up about $10 \%$ of the rock volume. The siliciclastic grains are about $50 \%$ of the rock volume. About $90 \%$ of them are angular quartz grains and $10 \%$ angular feldspar grains. Their grain sizes range from 20 to 110 microns with an average around 50 microns. The pore space is filled with sparite 
cement in the lower part of the bed and in the upper part of the bed partly with lime mud and partly with sparite.

The angular shape of the coarsest siliciclastic grains suggests that they have been transported in water. KUENEN (1964, p. 279) stated that grains with a size of less than 250 microns are not rounded during transport in water. It is important to note that a large quantity of clay minerals was in suspension during the transport of the siliciclastic grains. The clay minerals further augmented the minimum size of grains that would be rounded. If the siliciclastic grains were transported by the wind as BoLLIGER \& BURRI (1970) concluded, at least the coarsest grains of the fine sand fraction would be rounded (KUENEN, 1960, p. 51).

\subsubsection{Dolosparite}

Almost pure dolomites are uncommon and are restricted to the Günsberg and the Balsthal Formations. In the Balsthal Formation they occur both in the Laufen Member (for instance section RG 390 Moutier, Gorges de Moutier, southern part, pl. 27. bed 99, TS Gy 7032) and in the Verena Member. The figured dolosparite (fig. 16) is from bed 62, middle Verena Member, in section RG 381 in the Gorges de Court near Moutier BE (pl.28). The anhedral dolomite grains form a panxenotopic mosaic. The average grain size is 80 microns. Some grain interstices and few larger patches are filled with undolomitized micrite that amounts to about $5 \%$ of the rock volume. The bed has a thickness of $1.90 \mathrm{~m}$ and a few pores with a diameter of several millimeters. The rock has a saccharoidal appearance.

\subsubsection{Tidal flat facies}

\subsubsection{Mudstone with prism cracks}

Lime and argillaceous mudstones with prism cracks were found at several localities in the Vorbourg and in the Roschenz Members of the Vellerat Formation and in the Günsberg Formation. Prism cracks are conspicuous in lime mudstone (GyGl 1992, fig. 5), but if they occur in soft argillaceous mudstone, they are not easy to recognize because of the rapid weathering of marl. Prism cracks in marl may be preserved if pure lime mud was sedimented on top of the marl. In this case the imprints of the cracks are visible as positive ridges on the lower bedding plane of the lime mudstone overlying the marl. An example of this is the stromatolitic lowest part of bed 57 of section RG 320 at Montépoirgeat near Undervelier JU. The lime mudstone bed is partly laminated and contains birdseye pores and rootlets (RS Gy 3690). It is in the upper part of the Roschenz Member. The mud-cracked marl below is bed 56 which is $0.50 \mathrm{~m}$ thick and is a soft, grey-green marl with much detrital quartz.

The diameter of the prisms varies from 1 to $50 \mathrm{~cm}$ depending on the thickness of the cracked bed. The thickness of beds that are cracked from the top to the base may be as much as $60 \mathrm{~cm}$ as for instance bed 31 of section RG 417 near Crémines BE (GyGi 1992, p. 807) in the Günsberg Formation.

Recent mud cracks of the intertidal zone were reported from the Persian Gulf (KENDALL. \& SKIPWITH, 1968, fig. 5) and from the Bahamas (GINsBURG etal. 1977,fig. 4). Fossil prism cracks may be taken as evidence of the intertidal zone if the cracked bed contains birdseye pores, rootlets or mud pebbles. A lime mudstone with deep prism cracks was figured by Gral (1992, fig. 6) from bed 21. Gunsberg Formation, of section RG 414 near Grandval BE (RS Gy 4795. see also PS Gy 4794). According to GinsBurG. et al. (1977, fig. 4) this is indicative of the lower intertidal zone.

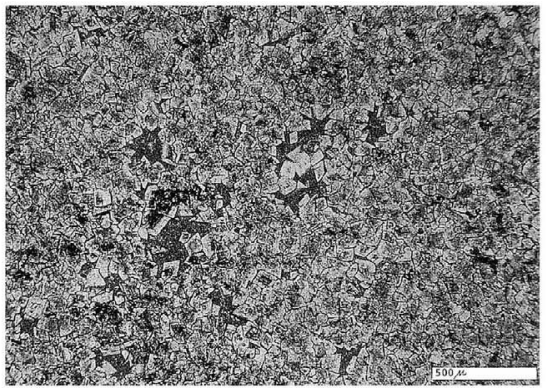

Fig. 16: Dolosparite with micritic. undolomitized patches, Verena Member, Court gorge, Moutier BE. TS Gy 7010 , section RG 381 . bed 62 (pl. 28). 


\subsection{Biofacies}

\subsubsection{Siliceous sponge assemblages}

Siliceous sponge assemblages are typical for the deep neritic realm not only in the Late Jurassic on the northern margin of the Tethys (RETTNer \& NeUweILER, coord. 1995, fig. 2), but also in the Late Triassic of the Sichuan Basin. China (WU 1989). In northern Switzerland the sponge assemblages with wholly fossilized sponges are associated with an abundant and diverse ammonite fauna. In this region part of the sponges were wholly fossilized in water deeper than about $50 \mathrm{~m}$. Only spicula survived in shallower water (see above). But this does not mean that dense growths of siliceous sponges did not exist in shallower water of the Late Jurassic. They are probably just not preserved. Sponge bioherms from shallow water have been found in the Callovian (Koenigi Subzone) near Ladoix in Burgundy. France (Floouet et al. 1991, p. 49, fig. 14, pl. 4E).

Even in their optimal depth range, special conditions were necessary for sponges to become fossilized. One of these conditions was the rate of mud sedimentation. If the rate was too low as for instance in the thin, deep neritic Mumienkalk Bed or in shallow, turbulent water, few or no sponges were wholly fossilized. If the rate of mud sedimentation became too high as in the lower Effingen Member, the sponges apparently became smothered when living and disappeared from the environment.

The richest and most widespread occurrence of siliceous sponges in northern Switzerland is in the Birmenstorf Member which is a very widespread, densely colonized sponge biostrome (fig. 17) that was deposited at a relatively low sedimen.

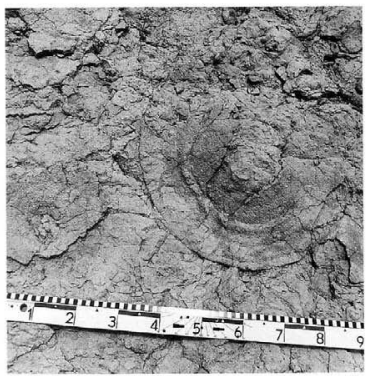

Fig. 17: Siliceous sponges of the genus Discophyma at the upper bedding plane of bed 34. section RG 276. quarry of Chalch, Holderbank AG (sce Gral et al. 1979, fig.3). Upper Birmenstorf Member. The sponge on the left is in life position and the specimen on the right hand side is overturned. Scale is in decimeters tation rate. This facies extends from the Klettgau along depositional strike to the southern Jura in southeastern France (ENA) 1966) and perpendicularly to the depositional strike to the autochthonous and parautochthonous facies realms as well as into the lower Helvetic nappes of the central and eastern Swiss Alps (KUGLER 1987,p. 75). This author gave a short and appropriate description of the Birmenstorf Member in Canton Aargau (KuGLER. 1987, p. 19-21) and figured (fig. B. 1. 7.) the upper bedding plane of bed 34 in the section RG 276 near Holderbank AG (in Grol et al. 1979, fig.3) that is covered with large dish-shaped siliceous sponges. KUGLER noted that the majority of the sponges were overturned. Few specimens are embedded in life position. According to Gyg1 (1986), the depth of deposition of the Birmenstorf Member in Canton Aargau was greater than $100 \mathrm{~m}$ and less than $150 \mathrm{~m}$. No sedimentary features that might be interpreted as tempestites have ever been observed in the Birmenstorf Member. Therefore it is probable that not currents, but animals overturned the sponges in search of prey animals hiding at the underside. In the Recent, rays and hogfish have been observed to overturn rocks and red algal nodules in the tropical western Atlantic (BöHLKE \& CHAPLIN 1970, p.33, and MACINTYRE et al. 1987, fig. 12).

\subsubsection{Ammonite assemblages}

There are faunal assemblages in the Late Jurassic of northern Switzerland in which ammonites are by far the most abundant element as for instance in the Schellenbrucke Bed of the early Oxfordian. This bed was deposited at a depth of $80-100 \mathrm{~m}$ (GYGl 1981, tab. 1, p. 243-244). Ammonites are classical guide fossils and were for a long time regarded to be relatively independent of facies. ZIEGLER (1963b, p. 238) denied this and claimed that ammonites were facies fossils as much as all others. ZIEGLER (1963a, p. 102) stated that most ammonites lived in close relation to distinct facies and therefore close to the sea bottom. The fact that this can be observed in the fossil record of the Late Jurassic in Central Europe implies that no large-scale transport of cmpty shells has taken place. ZIEGLER (1981, fig. 7) showed that ammonite diversity is at its optimum at moderate depths. ZIEGLer (1967, p. 449) established depth ranges for ammonite assemblages and other faunal assemblages of the Late Jurassic in Europe. He augmented and systematized the knowledge of earlier authors as for instance KILIAN (in BuLOT 1993 p. 246). Gra (1986) calculated the depth of deposition of Late Jurassic sediments in northern Switzerland and showed how the composition of ammonite assemblages varied with depth (GvG 1986, fig. 6), thus confirming and substantiating the results of ZIEGLER (1967).

Grol ct al. (1979, tab. 12,p. $942-946)$ analyzed the ammonite assemblage of the Mumienkalk Bed and discussed the palacoecology in detail. The same was done with the Schellenbrücke Bed (R. GYGI, 1981). Other important ammonite assemblages are in the Birmenstorf and in the Baden Members. EGger (1991) made a study of the biota of the Birmenstorf Member near Holderbank AG. Other important ammonite assemblages are in the Crenularis Member in the region of Mellikon AG and in the Hornbuck Member. Siliceous sponges are present in all 
of these stratigraphic units, but they are quantitatively important only in the Birmenstorf and in the Hornbuck Members (see above). Ammonite-dominated assemblages lived in water that was more than $50 \mathrm{~m}$ decp (Gral 1986, p. 480).

\subsubsection{Bivalve assemblages}

There are macrofaunas where bivalves are the dominant clement of the assemblage. The Kimmeridgian Hypselocyclum Zone at Mt. Born near Olten where bivalves comprise $55 \%$ of the macrofauna is such a case (Gygr 1986, fig.6B). The water depth of this assemblage was about $30 \mathrm{~m}$ (Grot 1986, fig. 6B). The next examples in descending stratigraphic order are the Wangen and the Crenularis Members in the region of Mt. Geissberg near Villigen AG and on Bözberg. Bed 30 (lower Crenularis Member) of section RG 63 which is a cliff above a ravine north of the ruin Besserstein near Villigen AG contains a bivalve assemblage that is dominated by very abundant Pholadomya pancicosia Rofmer. The Geissberg Member below includes an abundant and diverse bivalve assemblage that is dominated by Pholodonya and Goniomya (Moesch 1867. p. 147). The abundance of Pholadomya both in the Geissberg and in the Sornetan Members convinced MoEsCH (1867. p. 145) that the two members were of the same age. ETA1.Lon $(1862$, p. 245) even proposed the stage name Pholadomyen based on the Sornetan Member. ROLLIER (1893b, p.56) claimed that this stage name had been introduced by DE TRIBOLET). Bivalves are again very abundant in the Banne Member. Gva (1986, p. 477) assumed that assemblages dominated by bivalves lived in water that was between $20 \mathrm{~m}$ and $50 \mathrm{~m}$ deep.

\subsubsection{Coral assemblages}

Solitary deep-water corals are very rare and are always of small size. One specimen of such ahermatypic corals has been found in the Schellenbrticke Bed and another in the lower Mumienkalk Bed in the section RG 212. bed 8 near Siblingen SH. A specimen from the Crenularis Member is figured in Gral (1969, pl.6, fig. 23) and in GrGI (1992, fig. 24). Two more specimens were colleeted from the lower Baden Member of Mellikon and from the lower Schwarzbach Formation in the section RG 239 at Summerhalde near Schaffhausen. The specimens from the Mumienkalk Bed and from the lower Schwarzbach Formation lived at a water depth of more than $100 \mathrm{~m}$. The specimen from the Crenularis Member is from a depth of about $80 \mathrm{~m}$ (GYol 1986,p. 479). These deep-water corals belong to undescribed species.

Colonial or hermatypic coral growth began at depths of less than $20 \mathrm{~m}$. This can be calculated from section RG 306 at Hinter Chestel near Liesberg BL (GyGl \& Persoz 1986, p.412, see also Insalaco 1996. p. 184). The first hermatypic corals that appear in the Liesberg Member are flat and dish-shaped. They form a thickly colonized biostrome (fig. 32). Thin, dish-shaped colonies continue to a depth of about $10 \mathrm{~m}$. In general, further up the succession the colonies become thicker like a loaf of bread, then dome-shaped to massive or branching and it is at

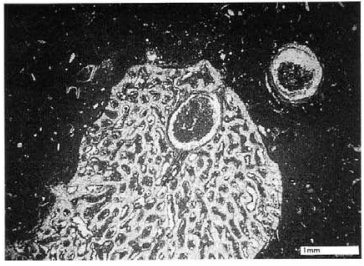

Fig. 18: Cladocoropsis mirabilis FELIx. section RG 431, quarry at Gansbrunnen SO bed 23, lower Reuchenette Formation. TS Gy 7181 (pl. 40).

this level that most coral bioherms begin to develop. No lateral zonation could be recognized in the studied coral bioherms due to insufficient outcrops. PUMPIN $(1965, \mathrm{p}, 843)$ was in a position to make a zonation of the lagoonal coral reefs at St-Ursanne and to deduce a palaeocurrent from the southsouthwest.

The coral bioherms of the Late Jurassic of northern Switzerland are unlike Recent coral reefs. Most of them were much more like sponge bioherms; they had a mud matrix (GyG1 1986. p. 477) and a low relief above the surrounding sediment (Pümpin 1965, fig. 14). Their vertical extent did not exceed $30 \mathrm{~m}$ (Groi \& Persoz 1986, p.413) and they have never been observed to coalesce into a barrier reef.

\subsubsection{Cladocoropsis assemblages}

RENZ (1931) studied Clatocoropsis mirabilis FFuX (fig. 18) from the Swiss Jura Mts, for the first time. He made the observation that these organisms with an uncertain systematic position are often the only mactofossils that can be found in the rock (p.2). They may be so abundant that they form a considerable part of the rock volume (RENZ 1931, pl, 1). This author figured Cladocoropsis from the Solothurn Turtle Limestone (see also Thalmann 1966, p. 104). Cladocoropsis has now been found in sediments as old as the lower St-Ursanne Formation, for instance in the drinking water well RG 359 near Bressaucourt JU, bed 13,TS Gy 6113 (pl. 18). The organisms also occur in the Vorbourg Member as in the quarry Sur Montni. section RG 344 near Courtemaîche JU, bed 25, TS Gy 6022. Another occurrence in the Vorbourg Member is in beds 42 and 53 of section RG 362 at Hasenschell near Movelier JU, TS Gy 6140-6142. Cladocoropsis was also found in the Hauptmumienbank Member of section RG 398 , bed $21 \mathrm{~b}$ in the limestone quarry of the former cement works at Liesberg BL, TS Gy 6524 (pl.32). The last Oxfordian occurrence is in the lower Laufen Member in section RG 307 , bed 203 in the quarry of La Charuque near Péry BE, TS Gy 5471 (pl.22). Cladocoropsis is never abundant in the Oxfordian-age sediments of the Central Jura. 
The first appearence of Cladocoropsis in the Kimmeridgian-age Reuchenette Formation is in section RG 433 in the quarry of Wăberhüsli above the railway station of Gänsbrunnen $\mathrm{SO}$, in the uppermost part of bed 18 (pl. 41 ), about $4 \mathrm{~m}$ above the base of the formation. The first mass occurrence of Cladocoropsis in this formation is on Mt. Chamben near Herbetswil $\mathrm{SO}, 50 \mathrm{~m}$ east-northeast of point 1215.1 . less than $10 \mathrm{~m}$ above the base of the formation (locality RG 432. coordinates $610.290 / 235.950$. TS Gy 7182. PS Gy 4999). Very abundant Cladocoropsis are also found in section RG 433 . bed 20 , in bed 35 below the Solothurn Turtle Limestone and in bed 47 above that unit ( $\mathrm{pl}$. 41). Many Cladocoropsis were found in the quarry RG 434 of Steingrueben near Lommiswil SO, bed 8 (TS Gy 7217. pl. 42).

The habital of Cladocoropsis was in very shallow-marine water and partially in lagoonal environments with possibly hypersaline conditions.

\subsubsection{Microbialitic assemblages}

Stromatolites and oncoids were for a long time believed to have originated only in the intertidal and in the shallow subtidal zones. Consequently, SzULCZEWSKI (1968, p.89) interpreted the Jurassic stromatolites of Poland to have been formed in very shallow water. PLAYTORD \& COCKBaIN (1969) proved that Devonian stromatolites of Australia had grown in the deep subtidal zone. GizeJEWSKa \& WieczoreK (1977, p. 174) concluded that the late Callovian stromatolite of Zalas in southern Poland was a sediment of the deep subtidal zone. Gror (1992) presented evidence that the stromatolites and oncoids from the Late Jurassic of northern Switzerland formed in environments ranging from the tidal flat down to the basin floor at nearly $150 \mathrm{~m}$ depth and figured pertinent examples from different depths.

\subsection{Fossil-dominated sediments}

\subsubsection{Siliceous sponge-dominated biostromes and bioherms}

Siliceous sponges (entirely or partially fossilized sponges and tuberoids) can be an important rock-forming element. As mentioned above, they can amount to as much as $30 \%$ of the rock yolume in the Birmenstorf Member. Siliceous sponges also form an important portion of the rock volume in the sponge bioherms of the Crenularis Member of Mellikon AG. Where partly or wholly fossilized siliceous sponges dominate in the rock, ammonites are always present.

\subsubsection{Coral-dominated biostromes and bioherms}

Coral biostromes are found within the argillaceous mudstones of the Liesberg Member, in the proximal part of the uppermost Effingen Member and in a lime mudstone groundmass of the Günsberg Member (ZIEGLER 1962, fig. 7). The corals in these biostromes are mostly thin and flat, dish-like colonies. They form up to $30 \%$ of the rock volume in the Liesberg Member. This biostrome is much more densely colonized than some coral bioherms at the margin of the St-Ursanne carbonate platform where small, massive coral colonies amount to only about $10 \%$ of the bioherm volume (section RG 315 , bed 34 , in the Pichoux gorge near Sornetan BE. pl.21). It is only in the lagoon of the St-Ursanne carbonate platform that corals form as much as $50 \%$ of the bioherm yolume (see above). The coral bioherms of St-Ursanne are therefore probably true reefs. Ammonites are very rare in coral biostromes. They have never been found within coral bioherms, but some occur in the inter-recf scdiment near St-Ursanne (Gygt 1995, figs, 4 and 6).
Fig. 19: Limestone made up mainly of Cycloserpula socialis (GoLDFUss) with some ostreids in a micritic matrix. Section RG 312 (unpublished). Montaigu near Souboz BE, bed 87. Laufen Member. PS Gy 3544. MNHB E 258/3. Scale har is $1 \mathrm{~cm}$.

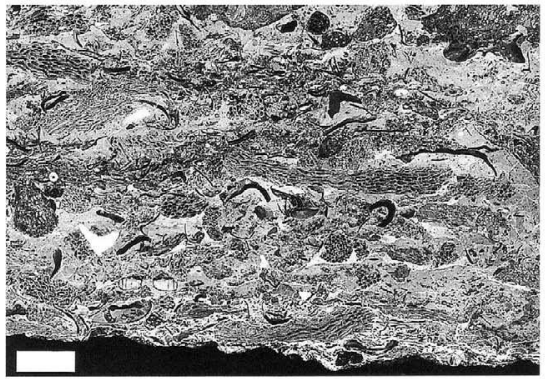




\subsubsection{Lagoonal fossil-dominated sediments}

The proximal part of the Laufen Member and the distal part of the La May Member are in some places extremely fossiliferous. Small ostreid bivalves, the rhynchonellid brachiopod Septaliphoria arduennensis (OPpel) and the worm Cycloserpula socialis (GoLDFuss) may be very abundant. Crinoids are uncommon and nautiloids are rare. Cycloserpula socialis forms more than $50 \%$ of the rock volume in bed 87 of section RG 312 (unpublished) on Montaigu hill near Souboz BE (fig. 19). The serpulids may be an indication of an episodically reduced salinity of the water.

\subsection{Vertical and lateral facies successions}

An idealized vertical facies succession in a shallowing-upward succession of the epicontinental basin of northern Switzerland has a thin bed of iron oolite with an ammonite-dominated macrofauna at the base. This is overlain by argillaceous mudstone which gradually becomes more calcareous upwards At the base the macrofauna is composed of ammonites and siliceous sponges (as for instance in the Birmenstorf Member) or spicula (Sornetan Member), and further up mainly of bivalves In the upper part of the mudstone succession the macrofauna is dominated by hermatypic corals. Coral bioherms can begin to grow without an initial biostrome stage as for instance in the Günsberg Formation. Above the corals there is usually a carbonate oolite. Some coral bioherms continue to grow within oolite banks like in the marginal part of the upper St-Ursanne Formation near Grellingen BL. Above the oolite are lagoonal and littoral facies like oncolite and stromatolites with prism cracks and fenestrae.

A typical lateral facies change from deep to shallow water can be seen in the coeval members of Hornbuck (lower part).
Geissberg, Steinebach and Hauptmumienbank (see GyGI \& Persoz 1986, pl. 1). The Hornbuck Member was sedimented on the basin floor at a depth of more than $100 \mathrm{~m}$. It is a succession of marls and limestones with sponge bioherms and ammonites. The lower part of this member grades laterally into the micritic. bedded limestones of the Geissberg Member which contains a rich bivalve fauna. Near Olten the Geissberg Member is laterally superseded by coral bioherms at the margin of the carbon ate platform of the Balsthal Formation. Behind these bioherms there is a wide belt of carbonate oolite. This oolite of the Steinebach Member grades laterally in the proximal direction into the lagoonal oncolite of the Hauptmumienbank Member.

The lateral facies transition of the lower Günsberg Formation to the lower Effingen Member can be followed in the field on the north slope of Mt. Raimeux west of the farm le petit Rambode. This is also visible on the topographic map Landeskarte der Schweiz 1:25000, northwest corner of sheet 1107 Balsthal. The lateral facies transition of the upper Günsberg Formation with coral bioherms to the Effingen Member can be seen in the landslide of Gschlief near Günsberg (section RG 14, see GyGt 1969, fig. 3). The same facies change has already been observed by MÜhlberg (in AMsLER \& MOHLBerg 1926, p. 687) east of the Chatzensteg gorge south of Ramiswil SO, Landeskarte 1:25000, sheet 1087 Passwang, coordinates 616.750/243,300. This is represented on the Gcological Atlas of Switzerland $1: 25000$, sheet no. 3 Laufen-Bretzwil-Erschwil-Mümliswil (1936).

The basinward thinning of the St-Ursanne and Pichoux Formations can be followed north of Nunningen SO from west to east between the rocks west of Balm, the Langenberg and Dictelloch, or east of Erschwil SO between the rocks west of Titterten and Hohruti west of Meltingerberg (Landeskarte, sheet no. 1087, Passwang). 


\section{Lithostratigraphy}

\subsection{The stratigraphical sections}

The stratigraphical sections published in this paper are grouped into four transects each running from north-northwest to southsoutheast, perpendicular to depositional strike (fig. 1). The sections east of Balsthal have been published by GrGl (1969) and else where (see caption to fig. 1).

\subsubsection{Transect Bure-Biel}

The Bure-Biel transect is in the southwestern part of the study area and incorporates data from 8 sections.

\subsubsection{Section RG 454 Bure.IU, well BUR 2 (pl. 16)}

An exploration well was drilled at the eastern margin of the village of Bure JU, coord.567.649/254.670. At the base of the borehole at a depth of $60 \mathrm{~m}$ there is a peloidal packstone which forms part of the lower Vorbourg Member. The remainder of the overlying Vorbourg Member (beds 1 to 18) is mostly a micritic lime mudstone with marly intercalations. In the upper part of bed 7 and in bed 18 there are stromatolites (pl.16).

The base of the Röschenz Member is marked by bed 19, a soft marl. Bed 22 is a lime mudstone with lithoclasts several centimetres in size. The marl of bed 27 also contains calcareous lithoclasts above a hiatus at the top of bed 26 . The oolitic wacketo grainstone of bed 38 is a regional marker bed. There are mud clasts several centimetres in size in the marl of beds 58 and 64 . Beds 62 and 65 are lumachelles.

The base of the Hauptmumienbank Member is bed 67, a lime mudstone that contains less than $10 \%$ oncoids with a diameter of up to $1 \mathrm{~cm}$. In the upper part of bed 68 is a thin oolitic grainstone with angular micritic lithoclasts that have a diameter of up to $1.5 \mathrm{~cm}$.

The base of the Bure Member is marked by bed 72 in which micritic limestone bands with a thickness of less than $10 \mathrm{~cm}$ alternate with marl bands of similar thickness. The member consists mainly of grey, homogenous marl of which bed 77 is a good example, and has a total thickness of $10.2 \mathrm{~m}$. Bed 86 marks the base of the micritic, bedded limestone typical of the overlying La May Member of the Courgenay Formation. At the top of the borehole the succession is strongly weathered and is capped by soil at the surface.

\subsubsection{Section RG 340 Porrentruy JU, quarry of Le Banné (pl. 17)}

This section is located in the old quarry on the castern slope of Le Banné hill. It was measured using a rope as described in section 1.4, therefore the beds are numbered from the top to the base. At the base of the section on the quarry floor is bed 88 , a white, porous lime mudstone representing the upper part of the Porrentruy Member of the upper Courgenay Formation. $6.4 \mathrm{~m}$ above the base are angular lithoclasts, terebratulid brachiopods and solitary corals with a diameter of $1 \mathrm{~cm}$. The uppermost $0.4 \mathrm{~m}$ of the bed is less porous. The uppermost $20 \mathrm{~cm}$ are thoroughly bioturbated. The upper bedding plane is covered with a thick limonite crust. Above the crust is a marly seam that marks the base of the Reuchenette Formation.

The lowest two beds of the Reuchenettc Formation are micritic limestones with a thickness of only $5 \mathrm{~cm}$ each (not represented in pl. 17). Bed 85 is a peloidal wackestone with burrows. The suceession above comprises lime mudstones up to bed 58 . Within this succession there are two beds with lithoclasts of a diameter of less than $1 \mathrm{~cm}$ (beds 76 and 70). Bed 53 is a micritic limestone with conspicuous burrows with a diameter of $1 \mathrm{~cm}$ that penetrate downwards from the sharp upper bedding plane. There is a great number of corals. Cerionya and nerineid gastropods in the pure white bed 46 . The overlying bed 45 is a pure white, porous peloidal packstone with very fine-grained peloids. Beds 22 to 14 contain an abundant fauna of bivalves with some gastropods. It is at this level that several large nautiloids have been found around Porrentruy. The upper bedding plane of bed 6 is a bored hardground. The marly Banné Member probably begins directly above bed 1 . Abundant bivalves and gastropods are scattered over the fields on the top of Banné hill.

\subsubsection{Section RG 359 Bressaucourt IU, drinking water well (pl. 18)}

A drinking water well was drilled on the bottom of the small valley south of the village of Bressaucourt to a depth of $150.2 \mathrm{~m}$. The lowest beds numbers 1 to 3 represent the uppermost Liesberg Member of the Bärschwil Formation. These beds consist of marl and marly, partly dolomitic limestone with partly silicified fossils. Dish-like coral colonies are only abundant in bed 3 .

Bed 4 marks the base of the St-Ursanne Formation, Grellingen Member (see below). It is a lime mudstone with discoid coral colonies. In bed 6 there are oncoids with a core of partially silicified bioclasts. The terebratulid brachiopods in bed 6 and the bivalves in bed 7 are also partially silicified. Bed 10 is an intercalation of oolitic pack- to grainstone. The lowest massive coral colonies occur in bed 13. Partially silicified serpulids oceur as high up as in bed 14. The surface dividing the lower St-Ursanne Formation (Grellingen Member) from the upper St-Ursanne Formation (Buix Member, see below) is at the top of bed 17. There is no indication of a hiatus. At the base of the Buix Member there is a massive, well-cemented lime mudstone (bed 18). This is the lateral equivalent of the lowermost "chalky limestone of St-Ursanne" of Ziegler (1962) at St-Ursanne. Bed 19 is the lowest typical, almost pure white and porous "chalky limestone of St-Ursanne". Bed 22 is a yellowish white oolitic grainstone with large solitary corals and pectinid bivalves. The upper bedding plane of bed 23 is covered with a 
limonitic crust. This marks the upper boundary of the St-Ursanne Formation.

The base of the Vorbourg Member corresponds to bed 24 and the top to bed 41 . The member consists of micritic, bedded limestone. There is a solitary coral in bed 29 , together with ostreids (PS Gy 4160).

The first bed of the Röschenz. Member is no. 42, a marly peloidal wackestone. This member mainly comprises variable marly limestones The marl intercalations are subordinate. There are beds with much detrital quartz, for instance nos. 47 and 52 . Stromatolites occur in beds 46,56 and 58 . Bed 73 is an oolitic wackestone, and is a regional marker bed that is also present in section RG 454 near Bure (see 3.1.1.1, bed 38). The Jurassic succession ends at the top of the marl of bed 79. Above is a conglomerate of Tertiary age.

\subsubsection{Section RG 350 Courgenay.JU, Chemin Pautin road (pl. 19)}

The base of the section is $500 \mathrm{~m}$ northwest of Vacherie Mouillard farm. The section was measured along a forest road called Chemin Paulin (this name is not indicated on the Landeskarte der Schweiz 1:25000, sheet 1085 St-Ursanne). The road runs through the forest of Montagne d'Alle southwest of Courgenay. The lowest bed shown on pl. 19 is no. 7 which is the tectonically sheared Hauptmumienbank Member. The oncoid content is about $30 \%$ of the rock volume at the base of the bed where the diameter of the oncoids is less than $5 \mathrm{~mm} .3 .4 \mathrm{~m}$ above the base the largest oncoids have a diameter of $1 \mathrm{~cm}$. Some of the oncoids have calcite pseudomorphs after gypsum forming their cores.

The soft, grey marl of the upper Bure Member was discontinuously exposed when the section was measured in 1981. Since then this part of the section has been completely overgrown by vegetation. The lower part of the La May Member is so thinly bedded that not all of the beds could be drawn on pl. 19. The member comprises a monotonous succession of lime mudstone. Bed 43 contains angular and rounded lithoclasts with a diameter of up to $2 \mathrm{~cm}$. There are some calcite pseudomorphs after gypsum in the groundmass. Above bed 43 the thickness of the limestone layers increases. Bed 59 is a tectonically sheared marl with micritic limestone boudins.

Bed 79 forms a ridge around which the road bends. The rock is unbedded, micritic lime mudstone with a yellowish white colour. There are densely spaced, deformed joints. This is the characteristic Porrentruy Member, but here it is not chalk-like and porous as it is near Porrentruy.

The Reuchenette Formation begins with a monotonous succession of slightly darker, yellowish-grey lime mudstones. Bed 95 is a particularly resistant micritic limestone that forms a small ridge. From bed 106 upwards there are peloids. Bed 116 forms a ridge above the road and a small waterfall in the gully below. Angular and rounded lithoclasts with a diameter of up to $2 \mathrm{~cm}$ occur in bed 132 together with partly empty burrows with a diameter of as much as $1 \mathrm{~cm}$. Above there are several beds with large bivalves.

The argillaceous Banné Member begins with bed 156. Bivalves are very abundant in beds 157 and 158 . The soft marl 159 contains only few macrofossils. This is the uppermost bed of the Banné Member.

\section{I.I.S Section RG 443 St-Ursanne.JU,} exploration well near La Coperie farm (pl.20)

The base of the section is at a depth of $162.6 \mathrm{~m}$ above a shear plane. Bed 1 is a soft grey-brown marl with a hight content of detrital quartz and it forms the uppermost bed of the Röschenz Member.

The lowest bed of the Hauptmumienbank Member is no. 2, an oolithic-oncolithic grainstone containing bivalves and small gastropods. Bed 3 is an oosparite. Oncoids up to $2 \mathrm{~cm}$ in size reappear only in bed 4 where they form 10 to $20 \%$ of the rock volume in a lime mud groundmass The top of the Hauptmumienbank Member is bed 7 .

The Oolithe Rousse Member is represented by beds 8 and 9 which are oopelmicrites. The Bure Member is characterized by marly limestones alternating with marls which contain very fine-grained detrital quartz. There are large parts of crinoid stems and brachiopods in this member.

The base of the La May Member is marked by bed 24, a lime mudstone. There are peloids in beds 31,40 and 52 to 59 . Oncoids occur in beds 32,45 and 49 . Most of the member consists of well-bedded lime mudstone. Angular lithoclasts with a size of up to $25 \mathrm{~mm}$ occur in bed 60 .

The Porrentruy Member is bed 65. It is massive, yellowishwhite. slightly porous and relatively soft. Brachiopods. ostreids and nerineids are fairly abundant. Oncoids reach a maximum diameter of $8 \mathrm{~mm}$. The upper boundary of the bed is a horizontal stylolite.

The lower Reuchenette Formation is a monotonous succession of well-bedded, micritic limestones. Peloids are uncommon, but bed 80 is a pelsparite. There is an uneven erosional surface within bed 83 . The Banné Member (bed 126) has a thickness of $3.5 \mathrm{~m}$. Only the lowest $20 \mathrm{~cm}$ are very fossiliferous. The macrofauna is dominated by ostreids and Trichites.

\subsubsection{Sections RG 314,315 Sornetan BE, Pichoux gorge $(p l .21)$}

The lower section, RG 314 , begins on the eastern bank of the Sorne creek northnortheast of the road tunnel. Bed 1 is a continuous band of fossiliferous, marly, blue-grey limestone. This is the regional fossil bed in the middle Sornetan Member (see Gygi \& Marchand 1993, fig. 2). The section goes only to the nodular bed 5 at this location, then it is covered by drift. The section continues in a small landslide at coordinates $584.160 / 237.100$ more than $100 \mathrm{~m}$ to the south, where beds 7 to 15 are exposed. Beds 16 to 18 had to be dug out at this location in order to make the contact between the Sornetan Member and the Pichoux Formation visible. The section continues more than $100 \mathrm{~m}$ to the north in a small gully through the lower escarpment of the Pichoux Formation. This is a succession of well-bedded. light brownish-grey micritic limestone. Above bed 44 the succession weathers back. The sections RG 314 and RG 315 overlap by more than 3 metres.

The base of section RG 315 is at a small shear plane on the roadside west of the Sorne creek. The bedding of the overlapping upper part of section 314 and the basal part of 315 could not be correlated between the opposite sides of the gorge. The link between the sections was therefore made according to the upper edge of the lowermost escarpment of the Pichoux For- 
mation which is well recognizeable on both sides of the gorge. Beds 3 to 15 of section RG 315 are brownish-grey, micritic limestones that weather back. Bed 16 is more resistant, it forms an overhang above a cave. Bed 20 , mainly the lowest $0.5 \mathrm{~m}$ of it, is marly and weathers back. The base of this bed is interpreted to correspond to the transgression surface near St-Ursanne where the coral bioherms of the upper St-Ursanne Formation start above the oolite of the lower St-Ursanne Formation. The northern entrance of the road tunnel is in the marly succession of beds 20 to 22 . The succession is purely micritic up to the particularly resistant bed 28 , the upper edge of which forms the upper waterfall of the Sorne. Bed 29 as well as beds $32 \mathrm{a}$ and b are wackestones with a high content of fine-grained bioclasts. The upper bedding plane of bed $32 \mathrm{~b}$ is uneven. This is the top of the Pichoux Formation.

The Pichoux Formation is overlain by bioherms of the StUrsanne Formation (beds 33 and 34). The bioherms weather out to the east of the road and the Sorne creek. Massive coral colonies are densely packed at the base of the bioherm on the western roadside. The base of the coral bioherms lies directly on the upper surface of bed $32 \mathrm{~b}$. There is no more than mudgrade bioherm-derived detritus between the bioherms. The coral colonies in the upper part of bed 33 and in bed 34 are mostly massive and only occasionally branching. The matrix of the bioherms is lime mudstone which forms about $90 \%$ of the bioherm volume. The bioherms are dissected by numerous tectonic fractures. The upper surface of bed 34 is even and very well-defined.

At the base of the Günsberg Formation is a soft, yellowish marl that is only a few centimeters thick (lower part of bed 35). The bulk of bed 35 is a bluc-grey micritic limestone with finegrained detrital quartz. There are lenses of pelmicrite in the bed with as much as $10 \%$ quartz. Bed 36 is a bioherm with a micritic groundmass at the base of which are thick discs of probably $\mathrm{Mi}$ crosolena. $3 \mathrm{~m}$ above the base of the bioherm the coral colonies become massive. The upper bedding plane is uneven. It is visible in the streambed of the Sorne, because a fault displaces the succession by $17.7 \mathrm{~m}$. Beds 37 to 44 are mostly micritic limestones and resemble the Vorbourg Member. Beds 45 to 49 are calcarenites with inclined bedding. Bed 45 is a fine-grained oolitic pelsparite and bed 47 is very similar, but it is laminated and contains some detrital quartz. Bed 49 is a bioclastic calcarenite (biosparite), the upper $2.8 \mathrm{~m}$ of which are visible along the road.

A soft marl $10 \mathrm{~cm}$ thick forms bed 50 . Beds 51 and 52 are both $10 \mathrm{~cm}$ thick and are stromatolites. The lower part of bed 56 is an oolitic biosparite. In the upper part of the bed there are branching corals and oncoids up to $2 \mathrm{~cm}$ in diameter enclosed in a lime mudstone groundmass. Bed 61 is $30 \mathrm{~cm}$ thick, and the entire thickness of it is dissected by prism cracks The bed is a wavy laminated stromatolite. It's upper surface is an undulating erosion surface that intersects the wavy lamination. Beds 62 to 65 above are stromatolites. The stromatolite of bed 65 is crinkled and has been figured in Gral (1992, fig. 12, Gy 4928). Bed 66 contains about $20 \%$ oncoids with a diameter of up to $5 \mathrm{~mm}$, fine desiccation cracks and birdseyes. The remainder of the Röschenz Member crops out above the road and is partly covered with drift and vegetation.
The succession resumes with the Hauptmumienbank Member whose lower part is exposed above the road. Only the upper part of the member is oncolitic: in bed $106 \mathrm{~b}$ there are about $30 \%$ oncoids with a diameter up to $2 \mathrm{~cm}$, and in bed $107 \mathrm{~b}$ there are about $30 \%$ oncoids the maximum size of which is $25 \mathrm{~mm}$.

The Oolithe Rousse Member goes from bed 108 to 111. Bed 108 is an oosparite with mostly micritized ooids and pseudomorphs of calcitc after dolomite and sulfate within the intergranular cement. Bed 109 is an oomicrite with brown, micritized ooids in an olive-green groundmass. The groundmass was first partly dolomitized, then totally dedolomitized and contains some detrital quartz.

The base of the Laufen Member is marked by bed 112 in which there are very abundant ostreids and some pectinids. Zeillerina astartina (ROLLIER) and Cycloserpula socialis (GOLDFuss) are associated with abundant ostreids in bed 113. Bed 115 is marly, weathers back and contains abundant detrital quartz.

The Verena Member is massive as usual. The lower part forms a high ridge whereas the upper part weathers back to form a hollow. Beds 120 and 121 are oobiomicrite, and no. 121 contains dedolomitized rhombs. Bed 122 is an oomicrite that was extensively dolomitized and then entirely dedolomitized. No. 123 is an oosparite with dedolomitzed rhombs. Oncoids up to $6 \mathrm{~mm}$ in diameter occur in a dedolomitized, oomicritic groundmass in bed 125 . There are grapestones, nerineid gastropods and ostreid bivalves in the pelsparitic to oolitic bed 127 . Bed 129 is an oosparite at the base, then an oolitic wackestone that grades into pure micrite at the top.

The lower Reuchenette Formation consists mainly of micrite with varying amounts of peloids, bioclasts and detrital quartz. Bed 137 is a conspicuous marl that dams up a spring at the eastern side of the gorge. The upper part of bed 153 and the whole of bed 154 are stromatolitic.

\subsubsection{Sections RG 307,458 Péry BE, La Chartique quarry (pl.22)}

The base of the section is exposed on the western side of the lower level of the quarry La Charuque where the uppermost part of the Callovienton Member crops out. The Dalle Nacrée Member (mainly bed 10 ) is a biosparite with inclined bedding. The bioclasts are mostly derived from echinoderms, but fragments of bryozoan colonies are also abundant. The upper surface of bed 10 is a planed and bored hardground with a limonitic crust.

The base of the Herznach Formation is marked by bed 11 which is $15 \mathrm{~cm}$ thick and contains abundant bivalves, bioclasts from echinoderms as well as iron coids. The iron ooids are concentrated in the upper part of the bed. Beds 12 to 18 are a succession of marly limestones with limonitic iron ooids and marl with iron ooids These are the "Anceps-athleta Beds" of previous authors. The upper bedding plane of bed no. 18 is covered with a thin crust of limonite. This is overlain by a clayey marl $15 \mathrm{~cm}$ thick with a brown-violet colour and $25 \%$ limonitic iron ooids (no.19). Characteristic of this rock are yellow-brown spots. Parts of crinoid stems, wood and belemnites are quite common. The ammonites of this bed are Kosmoceras sp., Quenstedtoceras lamberti (J. SowERBY) and Quenstedtoceras paucicostatum LANGE (GyGt 1990a, pl.3,fig.12). The upper surface of 
bed 19 is very well-defined. Bed 20 is a brownish to dark-grey. clayey marl $25 \mathrm{~cm}$ thick. The iron ooid content decreases from $20 \%$ at the base to zero at the top. At the base of the bed there are ammonites indicative of the Callovian Stage like Quenstedtoceras lamberii (GyGl 1990a, pl.3, fig. 13) and Quenstedtocerns leachi (J. Sowerby) (GYGI 1990a, pl. 3, fig. 10). In the upper part of the bed the first Oxfordian ammonites appear, for instance Candioceras (Scarburgiceras) cf. scarburgense (Young \& BIRD) (Gyal 1990a,pl.3, fig. 11). The Callovian/Oxfordian boundary is therefore within bed 20. The upper boundary of this bed is transitional; it is drawn where the iron ooids disappear.

The Bärschwil Formation is represented by bed 21 which is $3.3 \mathrm{~m}$ thick and is a blue-grey. homogenous clayey marl. This is the Renggeri Member in which ammonites are rare (see GrG! $1990 \mathrm{a}$, pl. 6, fig. 3).

The Pichoux Formation begins with bed 22 above a hiatus of four ammonite subzones. The normal thickness of the bed is $0.8 \mathrm{~m}$. It is a biopelmicrite with glauconite and siliceous sponges. Two small sponge bioherms were visible in this bed in the southern part of the quarty in 1980 which doubled the thickness of bed 22. Perisphinctes (Dichotomosphinctes) arlecedens SALFEL was recovered from this bed (Gyor 1990a, pl.5, fig.4). Bed 27 is a glauconitie spiculite. There is a marly intercalation in the lower Pichoux Formation (bed 41) that can be correlated with section RG 315 (Pichoux gorge) and other sections. The upper part of the Pichoux Formation is well-bedded micritic limestone with some very fine-grained bioclasts. The upper bedding plane of the uppermost bed of the formation (no. 77) is hummocky and covered with a crust of limonite or iron sulfide.

At the base of the Wildegg Formation (Effingen Member) is a thin succession of micritic limestones (beds 78 to 83 ) with marly intercalations. This is overlain by a predominantly marly succession. Unit 92 is composed of micritic limestone beds with a maximum thickness of $30 \mathrm{~cm}$ each. Larcheria subschilli (LEE) has been recovered from the upper part of this unit. The thin and often laminated sandy intercalations in the Effingen Member are often dolomitized like bed 94 (thin section Gy 5440). These are probably small turbidites. A Perisphinctes (Ampihilia) quadraurs ENAY has been found in the succession of unit no. 99 (GYol 1990a. pl.7, fig.5) indicating the lower Bifurcatus Zone. Bed 102 is a very thick marl with some thin calcareous intercalations. In one of these intercalations Perisphinctes (Dichotomoceras) bifurcatoides ENAY has been found. Beds 103 to 109 clcarly demonstrate a thickening-upward succession. The uppermost bed of succession no. 112 is conspicuous. This bed forms the base of section RG 458 which was measured in 1995 about $300 \mathrm{~m}$ south of the tunnel in the La Charuque quarry, because a part of section 307 was covered by debris in 1980 . Beds $458 / 9$ and $307 / 14$ are the same. Section RG 307 continues with bed 114 in the upper part of bed 9 of section RG 458 . Bed $307 / 119$ is a hard, bluc-grey limestone with a thickness of $0.9 \mathrm{~m}$. In this bioarenitic wackestone are numerous druses with a diameter of up to $5 \mathrm{~cm}$ with calcite and celestite, BURKHARd (1978, p. 27, 79) reported very pure celestite from Péry, but he thought it was from "fossilrich, grey limestone of the Sequanian" (= Gunsberg Formation?). It is probable that his stratigraphic classification is erroneous and that the celestite bed of section RG 307 , bed 119 and BURKHARD's bed are the same.
The abundance of tempestites in the uppermost part of the Effingen Member is interpreted to be an indication of relatively shallow water. A good example is bed 115 , a laminated quartz arenite $20 \mathrm{~cm}$ thick with microsparitic cement and coarse-grained bioclasts at the base. This bed resembles bed $160 \mathrm{e}$ adjacent to a bioherm further up in the succession (GYGl 1986 , fig. 7). A similar bed is no. 125 with planar lamination. The upper bedding plane is an erosional surface with coarse parallel grooves. The ridges between the grooves resemble ripples, but they are not ripples, because the lamination of the ridges is horizontal and is intersected by the groove casts of the overlying bed. The first hermatypic corals appear in bed 144. Beds 145 and 148 are proximal tempestites. Bed 145 is a marl with a thickness of $0.5 \mathrm{~m}$. Embedded in the marl are nodules with a diameter of $20 \mathrm{~cm}$. The nodules have a matrix of lime mud that was semi-consolidated at the time of the storm. Enclosed in the nodules is a complicated pattern of striated bioruditic floatstone.

The base of the Günsberg Formation is marked by the foot of the bioherms of bed 160 (GYG1 1992, fig. 19). The matrix of the bioherms is lime mudstone. The colonization by corals is in parts so dense that they form framestones. The coral colonics at the base of the bioherms are dish-shaped to massive. Further up. branching forms are intermingled with massive colonies. There are stromatolites adhering to the corals (GyGI 1992, fig. 20). The bioherms include large lenses of soft marl. Some massive coral colonies have been observed to be overturned. The top of the bioherm at the southern entrance of the tunnel is a corroded, rough surface covered with a limonite crust. Above the bioherm is the thick cross-bedded oosparite of bed 162 . The upper boundary of this oolite is a corroded hardground. The hardground is in some places overlain by lenses of lignite with plant fragments (branches?) up to $25 \mathrm{~mm}$ in diameter and characean gyrogonites. Bed 163 is a petroleum-green oncolitic, mud-supported floatstone. The oncoids reach a diameter of as much as $5 \mathrm{~cm}$ (GYGl 1992, fig. 14). Nerinean gastropods sometimes form the oncoid cores. Massive and branching coral colonies are common. This is the "Grüne Mumienbank" (= green oncolite) of ZIEGLER (1956, pl. 2, fig. 1). The upper Gunsberg Formation is a variable, partly oolitic succession with another lignitic intercalation (bed 178). There are three conspicuous layers of marl in the uppermost part of the formation: beds 186,188 and 191.

Bed 192 marks the base of the Balsthal Formation and is a marly limestone with many fossils. The beds 193 to 195 are calcarenites with inclined bedding. The inclination of the internal layers of beds 193 and 194 is to the north-northeast and that of bed 195 to the west-northwest. These beds are interpreted to be part of a tidal delta which prograded into a lagoon. The currents must have been strong. but nevertheless the rock of bed 193 is an oomicrite with only occasional sparitic interstices (fig. 13). The upper bedding plane of bed 195 is a hummocky hardground that is covered with a limonitic crust. Beds 193 to 195 represent the Steinebach Member but are atypical facies.

Bed 196 is the lowermost of the Laufen Member. It is a limey marl with about $20 \%$ dark green peloids and many fossils. Oncoids in a micritic matrix occur in beds 199 to 201. The oncoids in bed 201 are about $20 \%$ of the rock volume and have a diameter of up to $35 \mathrm{~mm}$. The succession from beds 197 to $202 \mathrm{might}$ 
easily be mistaken for the Hauptmumienbank Member. The lower part of bed 212 is a lime mudstone with burrows that penetrate as deep as $70 \mathrm{~cm}$ from the upper part of the bed. Druses lined with calcite with a diameter of up to $10 \mathrm{~cm}$ are dispersed within the bed. Their origin is uncertain, because they are too large to be interpreted as open burrows. Pieces of plants several centimeters in size occur in the upper part of the bed.

The boundary between the bedded Laufen Member and the massive Verena Member is conspicuous. The rocks of the Laufen Member are light blue-grey to greenish-grey, whereas the limestone of the Verena Member is yellowish-white. Bed 227 is an oosparite with micritized ooids. $228 \mathrm{~b}$ is a pure lime mudstone. Oncoids are to be found in bed 231 and mainly in bed 232 . The upper bedding plane of 232 is a hummocky erosion surface. On top of it are $2 \mathrm{~cm}$ of soft, yellow-brown marl. In the lowermost part of bed 233 are blackened lithoclasts up to $8 \mathrm{~cm}$ in diameter. The larger lithoclasts are rounded, whereas the small ones are angular. The uppermost few metres of the Verena Member are pure lime mudstones. The member is nevertheless distinct from the overlying micritic lowermost Reuchenette Formation. At the boundary there is a marly seam about $1 \mathrm{~cm}$ thick. The limestone of the lowermost Reuchenette Formation is much thinner bedded than the massive Verena Member below, and it has a darker colour (light brownish-grey).

Bed 236 of the Reuchenette Formation is a stromatolite. Further up the rock contains varying percentages of peloids.

\subsubsection{Transect Delémont-Grenchen}

\subsubsection{Section RG 366 Delemoni, Vorbourg chapel (pl.23)}

Beds 1 and 2 of the lower St-Ursanne Formation, Delémont Member (see below) are an oomicrite with occasional small oncoids. The amount of micritic cement decreases upwards until the rock is an almost pure oosparite in bed 5. Bed 7 contains coral clasts and oncoids of probably foraminiferal origin with a diameter of up to $1 \mathrm{~cm}$. Ooids are present in beds $1-9$.

Bed 10, the lowest unit of the Buix Member (see below), is a bioarentic packstone to bioruditic floatstone with large, massive coral colonies. There is a small bioherm at this level above the road. A porous, white biomierite forms the massive bed 11 . Bed 12 is also massive, it is very resistant to erosion and forms the ridge on which Vorbourg chapel is built. ZIEGLER (1962, pl. II/15) included this unit into his Vorbourg Member. It is better to interpret it to be the uppermost part of the St-Ursanne Formation, because the well-bedded Vorbourg Member only begins above an even, corroded bedding plane at the top of bed 12 .

The base of the Vorbourg Member is marked by bed 13 and the top by bed 24. Part of the well-bedded succession of mainly lime mudstone has been tectonically sheared (cf. ZIEGL.ER 1962 , pl. IV/15). Some of the partings between the limestone beds are marly. The member weathers back.

ZiEGLer. (1962, pl.11/15) also included the lowermost Robschenz Member in his Vorbourg Member. The base of the Rosschenz Member is marked by $0.5 \mathrm{~m}$ of soft marl (bed 25). Bed 31 is also marl. Such thick marls do not occur in the Vorbourg Member as it is conceived by most authors. Bed 35 is a peloidal sandstonc. Most of the beds until no. 50 contain abun- dant detrital quartz. Bed 50 is a stromatolite. The uppermost thick marl is bed 65 . Bed 66 is a marly limestone that becomes increasingly calcareous upwards.

The Hauptmumienbank Member begins with the peloidal biosparite of bed 67 . The first oncoids with a diameter of up to $2 \mathrm{~cm}$ appear in bed 71 where they form about $20 \%$ of the rock volume. In bed 73 the oncoids form 20 to $30 \%$ of the rock volume and grow to a diameter of $3 \mathrm{~cm}$. They weather out as knolls at the rock surface.

The Oolithe Rousse Member is primarily an oomicrite. The cement was thoroughly dolomitized and then entirely dedolomitized (TS Gy 6206). It has a greenish-grey colour, whereas the ooids are red-brown. The Oolithe Rousse Member encompasses beds 74 to 77 .

The Bure Member begins with yellow-brown marl that alternates with light-grey marly limestone (bed 78). This bed contains brachiopods like Zeillerina astartina (ROLLER) (= "Zeilleria humeralis" auctorum) and the rhynchonellid Septaliphoria ct. semiconstans (EtalloN). The member ends with the biopelmicritic, marly limestone of bed 81 .

The Laufen Member is relatively thin-bedded. Bed 85 is a micrite with some peloids. The groundmass has been intensely dolomitized and then completely dedolomitized. Bed 92 is similar, but it contains bioclasts instead of peloids.

The boundary between the Laufen and the Verena Members is well-defined. It is drawn at the base of the massive bed 103 . The lowermost $40 \mathrm{~cm}$ of this bed are a wackestone with finely arenitic bioclasts. The Verena Member is made up mostly of oosparite, but beds 106 and 107 were primarily a lime mudstone. No.106 was totally dolomitized and then entirely dedolomitized. It is now a calcitic sparite.

The base of the Reuchenette Formation is marked by a succession of relatively thin-bedded, micritic limestones. Further up, the bedding becomes thicker, and the rock contains varying amounts of peloids and fine-grained bioclasts. GREPPIN (1893, p. 16) called this succession with a thickness of about $26 \mathrm{~m}$ "Couches du Vorbourg". This term was not taken up by subsequent stratigraphers and has been forgotten. On the other hand, the Vorbourg Member of ZiEGLER (1962, p. 21) has been adopted in a restricted sense by several authors and is now wellestablished in the geological literature (BOLLIGER \& BURRI 1970, p. 72 or HECKENDORN 1974, p. 11 and GEOLOCISCHER ATLAS DER Schwe1z, Blatt 1085 St-Ursanne 1963, Blatt 1067 Arlesheim 1984).

\subsubsection{Sections $R G 373,389,451$ Vellerat $J U$. \\ Peuse Roche (fig. 20, pl. 24)}

Section RG 373 begins in the larger, eastern of the two landslides ca. $170 \mathrm{~m}$ northeast of point 957.9 , below Peute Roche southwest of the village of Vellerat JU. Beds 1 to 47 belong to the Sornetan Member. The main body of this member is a grey marl. Intercalated in the marl are bands of limestone concretions, the so-called "chailles". The lateral distance between these nodules varies widely, and the nodules may coalesce into continuous beds of limestone. Bed 10 is a massive limestone with a thickness of $0.6 \mathrm{~m}$. This is a local marker bed (GYGi \& Marchand 1993, fig. 2). The vertical distance of the nodule bands is also variable. There is a concentration of nodules 
Fig. 20: Cliff of Peute Roche $1 \mathrm{~km}$ southwest of Vellerat JU as secn from the south. Arrows indicate the location of sections RG 373, RG 389 and RG 451 (pl. 24).

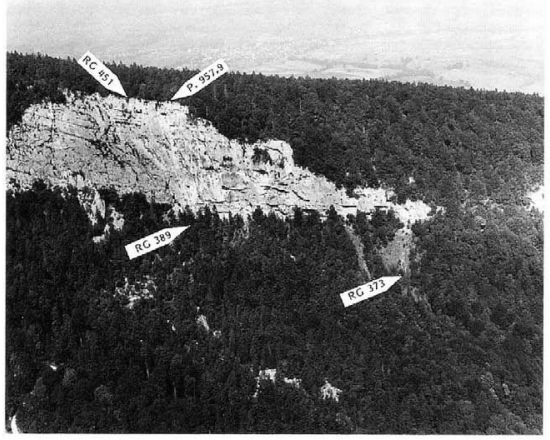

around bed 28 which contains flattened nodules that are more than $1 \mathrm{~m}$ widc.

The base of the Liesberg Member is fixed at the level where the first hermatypic corals and silicified serpulids appear. The corals are mostly plate-like, but small solitary corals are also abundant. Spines of Paracidaris florigemma (PHILLIPS) and calcareous sponges are quite common. In the middle of the member, in bed no. 2 of section RG 389, the coral colonies are cuplike. The uppermost part of the Liesberg Member is accessible at the foot of the cliff directly below point 957.9 .ca. $170 \mathrm{~m}$ to the southwest, where section RG 389 has been measured.

The lower boundary of the overlying St-Ursanne Formation is transitional. It is drawn where the rock becomes calcareous enough to form a cliff. This is at the base of bed 6 of section RG 389.30 to $40 \%$ of the volume of this bed are flat or cup-like coral colonies that are up $1060 \mathrm{~cm}$ wide and $6 \mathrm{~cm}$ thick. The upper end of section RG 389 is at a conspicuous parting that is vis. ible from a greater distance, at the top of bed 11. Bed 11 is the last one with flat coral colonies. The groundmass is a biomicrite. Section RG 451 begins about $45 \mathrm{~m}$ west of point 957.9 (fig. 20). Bed 1 of this section is a massive biomicrite with massive coral colonies. This is the typical facies of the Grellingen Member (see below). Bed 2 is an oosparitic intercalation. Bed 3 is again biomicrite with massive coral colonies and solitary corals. This is the upper part of the Grellingen Member. The Tiergarten
Member of the upper St-Ursanne Formation is an unbedded, almost pure oosparite (bed 4) with peloids at the top (bed 5).

The lowermost part of the Vorbourg Member ( $4.3 \mathrm{~m}$, beds 6 to 9) crops out in the uppermost part of the cliff. These four beds are micrite with some very fine-grained detrital quartz (thin-section Gy 7438, bed 8). The section ends with bed 9 .

\subsubsection{Section RG 377 Rebervelicr IU. \\ La Roche St-Jean (fig. 2l, pl.25)}

The section begins with the St-Ursanne Formation that forms the high ridge of Les Ordons. This formation is sheared along scveral planes and cannot be measured in detail (fig. 21, on the right hand side). It is therefore not represented in pl.25. The detailed section starts north of a $22 \mathrm{~m}$ wide gully that is filled with talus.

Beds 18 and 19 form a narrow, prominent ridge. This is the Hauptmumienbank Member of the Vellerat Formation. The oncoids grow to a diameter of $15 \mathrm{~mm}$ in the upper part of bed 18 . $2.5 \mathrm{~m}$ above the base of bed 19 there are about $40 \%$ oncoids with a diameter of up to $35 \mathrm{~mm}$. To the north of this ridge is a deep, narrow $(3.8 \mathrm{~m})$ groove filled with talus.

The section resumes with a succession of relatively thinlybedded limestone of the Laufen Member (beds 20 to 28). Bed 28 is a floatstone with ca. $30 \%$ oncoids that have a diameter of $8 \mathrm{~min}$ at most. 
Fig. 21: Section RG 377 , La Roche St-Jean southwest of Rebeuvelier JU as seen from the west. On the right hand side (south): sheared ridge of the St-Ursanne Formation. On the left (north): Hauptmumienbank Member (slender, low ridge). Laufen Member (vegetaled notch) and Verena Member (high ridge). Compare with pl 25, For key to ab. breviations see caption to fig. 39 .

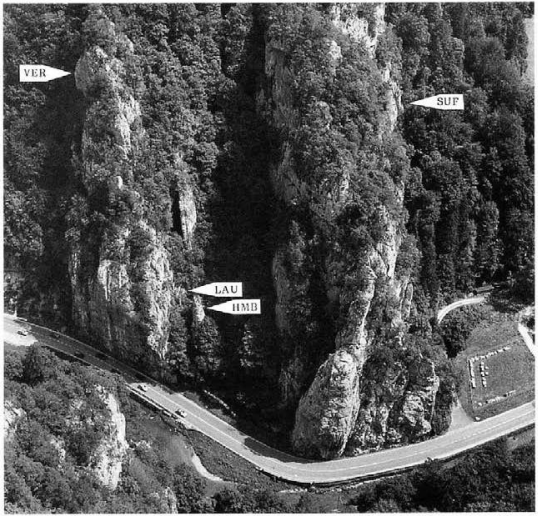

The Verena Member forms a high ridge directly beside the road. $2.8 \mathrm{~m}$ above the base of bed 29 the rock is an oolitic packstone. The ooids are micritized, and the primarily micritic cement was almost totally dolomitized and is now completely dedolomitized. The surface of the ooids has been indented by the dolomitization process and looks blurred under the handlens. This is the typical facies of the Verena Member. $17.4 \mathrm{~m}$ above the base of bed 29 there is a biopelmicrite with some dedolomitized rhombs. 18.3 and $21.1 \mathrm{~m}$ above the base the rock is a pure lime mudstone. At $24.4 \mathrm{~m}$ above the base of the massive bed 29 is a fine-grained pelsparite. At $34.5 \mathrm{~m}$ is a pelmicrite with a few ooids and oncoids $42.7 \mathrm{~m}$ above the base there are abundant foraminifers and some Cladocoropsis in a pelmicrite. The top of the Verena Member is marked by bed 31 which is a pelsparite in the middle. Oncoids with a maximum diameter of $5 \mathrm{~mm}$ are about $30 \%$ of the rock directly above.

The base of the Reuchenette Formation is marked by relatively thin beds of micrite and biomicrite such as bed 33 which contains dedolomitized rhombs and ruditic bioclasts.

\subsubsection{Section RG 392 Moutier BE, Moutier gorge, Arète du Raimelux (pl.26)}

This roadside section begins in the Laufen Member, in the middle of a bend of the road. Bed 1 is an oncolitic floatstone with about $25 \%$ oncoids that grew around ostreid shells and gastropods to a size of $1 \mathrm{~cm}$. The upper part of bed 2 is very similar.

The massive bed 5 is the first of the Verena Member. $2.8 \mathrm{~m}$ above the base there is an oomicrite with an almost totally dolomitized cement. The dolomitc crystals indented the micritized ooids. Then the rock was entirely dedolomitized. Bed 6a forms a notch above the road and is only fully accessible about $18 \mathrm{~m}$ above the road. $3.8 \mathrm{~m}$ above the base there is a porous, fine-grained oosparite with some aggregates of gypsum crystals. The gypsum was dissolved during the early diagenesis when there was still a high porosity, because the vugs are partly filled with early vadose silt (see DunHam 1969, fig. 6B). The remainder of the Verena Member is mostly pelsparite. The upper boundary is hummocky and forms the lowest, very large bedding plane in the quarry above the road.

Above this bedding plane there is an abrupt change in lithology. The massive, light Verena Member is overlain by the darker micrite of bed 10, the lowest bed of the Reuchenette Formation. This formation is mainly micrite with some peloidal intercalations.

\subsubsection{Section RG 390 Moutier BE, southern part of Moutier gorge (fig. 22, pl.27)}

At the base of the section is the Pichoux Formation. The outcrop begins beside the railway near the forward signal to 
Moutier. Bed 1 is a marly bioarenitic wackestone. Bed 2 is a slightly marly spiculitic biomicrite. The marly micrite of bed 29 again contains abundant sponge spicula. Some spicula were also found in the micrite of bed 39.

The first hermatypic coral colonies of the St-Ursanne Formation appear in bed 44 . The groundmass of the primarily biomicritic bed 45 is intensively dolomitized, but the bioclasts are calcitic. The dolomitization persists into the lower part of bed 46. The upper boundary of the St-Ursanne Formation is not visible. Above bed 52 there is a $7.6 \mathrm{~m}$ wide, channel-like hollow filled with talus. It is probable from a comparison with outcrops on the southern slope of Mt. Raimeux to the east that there is marl underneath the debris. If this is so, the succession 53 to 57 has to be assigned to the Günsberg Formation. There are perisphinctid ammonites in this succession, but they cannot be identified to the species level. Detrital quartz is also present, but it is so scarce that this is inconclusive of the presence of the Günsberg Formation.

To the south, above bed 57 there is a depression with a width of $22.2 \mathrm{~m}$. The section continues ca. $20 \mathrm{~m}$ above the road with bed 58 that has a knobby aspect. It is a peloidic packstone with ruditic bioclasts, but it does not contain corals. These are present only in the overlying bed 59 , where there are massive colonies from $1.7 \mathrm{~m}$ above the base. Massive coral colonies may make up $50 \%$ of the volume of bed 60 to form a coral bioherm. Bed 61 with its inclined bedding forms a high ridge ("GUN" on fig. 22). The upper part of bed 62 , an oobiosparite, was exposed in a temporary excavation on the western side of the road which extended up to bed 82 .

Bed 65 is a dolomitic, quartz-sandy microsparite. The foraminifer Alveosepta is very abundant in the sandy pelmicrite of bed 66 . Bed 79 is a layer of calcrete nodules with a diameter between 4 and $10 \mathrm{~cm}$ in greenish-grey marl. The upper boundary of the marl of bed 80 is a lignite seam with a thickness of $1 \mathrm{~mm}$ to $3 \mathrm{~cm}$.

The Hauptmumienbank Member forms a narrow, high ridge ("HMB" in fig. 22). The oncoids form up to $20 \%$ of the rock volume in bed 86 and reach a maximum diameter of $2 \mathrm{~cm}$ at the base of bed 87 . Bed 88 is supported by a masonry half arch above the railway. Bed 89 is a biopelmicrite with about $5 \%$ fined-grained quartz sand. This marly limestone with a brown groundmass is a marginal facies of the Oolithe Rousse Member.

The Laufen Member ("LAU" in fig. 22) is characterized by extensive dolomitization and oncoids. Bed 94 is a partly dolomitized and partly dedolomitized oncolitic floatstone. There is only slight dolomitization, and no dedolomitization in bed 95 .

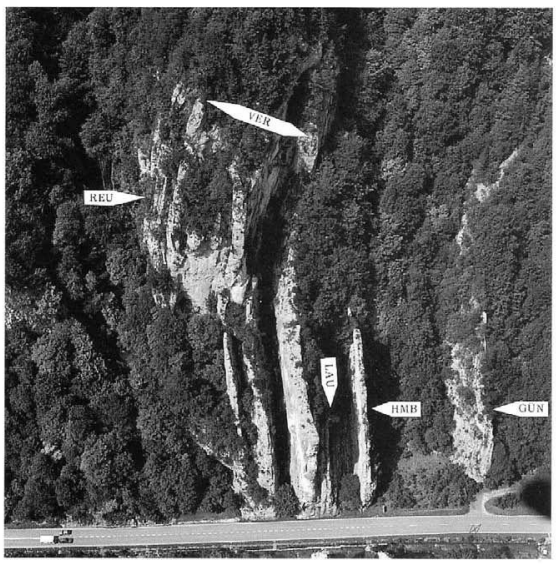

Fig. 22: Section RG 390 Moutier $\mathrm{BE}$, Moutier gorge, southern part as seen from the east. Compare with pl.27. 
There is again almost no dedolomitization in the dolomitic, oncolitic floatstone of bed 97 . The masonry half arch supporting bed 88 rests on the lower bedding plane of the dolomitic bed 98 which is very fossiliferous. $2.3 \mathrm{~m}$ above the base of this bed oncoids up to $3 \mathrm{~cm}$ in diameter make up as much as $40 \%$ of the rock volume. Bed 99 is, $0.8 \mathrm{~m}$ above the base, a dolosparite with calcite spar in the dolomite interstices.

The Verena Member begins with bed 100 , a massive limestone that forms a very high ridge (fig. 22) $3.6 \mathrm{~m}$ above the base it is an oomicrite with micritized ooids. The groundmass is almost wholly dolomitized and completely dedolomitized. The dolomite crystals indented the ooids and thus obscured the oolitic texture of the rock. The beds 101 and 102 form a deep noteh. Bed 102 is an oosparite whose ooids often do not break under the hammer. Beds ns 103 and 104 form high ridges. Above bed 104 the rock is tectonically disturbed and cannot be measured in detail.

\subsubsection{Section RG 381 Moutier BE, Court gorge (pl.28)}

The section begins on the bank of the Birs River $20 \mathrm{~m}$ up river from where a thick pressurized water pipeline crosses the Birs River. In the lower part of bed 2 there are plate-like corals and in the upper part massive coral colonies. Bed 3 is only $15 \mathrm{~cm}$ thick. It contains massive coral colonies that are overgrown with ostreids, and many lignitic bioclasts up to several centimetres in size. There is again plant debris in bed 6 . The upper part of bed 12 crops out beside the cantonal road. In 1958 the first fragment of a perisphinctid ammonite was found by the author in the upper half of bed 13. During a second visit with $P$. Allenbach more specimens were found, among them the Perisphinctes (Dichotomosphincles) sp. indet. aff. falculae RoNCHADZE that has been identified by J. Callomon (see ZIEGLER 1962, p. 42). The upper surface of bed 14 is erosional with a relief of up to $15 \mathrm{~cm}$. The upper parts of bed 15 and bed 17 are stromatolitic. Bed 21 is another stromatolite. There is a planed and bored erosion surface with encrusting ostreids on top of bed 28 (bed 10 of ZIEGLER 1956, p. 92) which in turn are overlain by a limonitic crust. This surface is easily visible south of the road. Beds 37 and 38 are an oosparite. There is some inconspicuous cross-bedding in no. 37 . Bed 38 has an internal inclined bedding with a depositional dip of 15 to $20^{\circ}$ to the north and northnortheast. The upper bedding plane is a hummocky erosion surface that cuts through the ooids (TS Gy 7005). The surface is covered by some ostreids and a brown crust. Bed 39 has a knobby weathering surface. It contains numerous large, mostly massive and some discoidal coral colonies that are bored by Lithophaga and another boring organism. The corals are recrystallized to white calcite spar. Many contain druses or may be entirely preserved as druses (sec ZIEGLER 1956, p. 93 , section 49 , bed 15). The bed is a blue-grey peloidal, bioruditic floatstone with Trichires, rhynchonellids and sea urchin spines. Mainly in the upper part of the bed there are pockets of soft. grey marl. The lower part of the section ends where a retainig wall begins that partly covers bed 40 at coordinates $593,000 / 234.280$.

The section continues to the northeast at coordinates $593.340 / 234.530$ below a commemorative table at the cliff west of the road, about $60 \mathrm{~m}$ south-southwest of the southern end of the new bridge. Bed 42 marks the base of the Hauptmumienbank Member and contains 5 to $50 \%$ oncoids with a diameter of less than $1 \mathrm{~cm}$. The diameter of the few oncoids in bed 43 is up to $3 \mathrm{~cm}$. The groundmass is micrite up to bed 45 . It becomes partly sparite in bed 46 , the last of the Hauptmumienbank Member. Bed 49 is an oomicrite with micritized ooids that are lined with a brown crust. The petroleum-green groundmass is mostly dolomitized and contains much detrital quartz with a grain size of up to 250 microns. This is the typical facies of the Oolithe Rousse Member.

The oldest bed of the Balsthal Formation (Laufen Member) is no. 50. It is an oncolitic floatstone with a dolomitized and dedolomitized micritic groundmass, Oncoids occur up to bed 54 .

The base of the Verena Member is marked by the massive bed 58 , an oolitic grainstone with micritized ooids that often do not break under the hammer. There are druses filled with calcite that are up to several centimeters across. These are calcite pseudomorphs after gypsum. An ill-sorted peloidal packstone with an ochre cement forms bed 61. The cement is probably dedolomite. This is the last bed (29) that ZIEGLER (1956, p. 93) assigned to the Verena Member. Bed 62 is a saccharoidal dolosparite with few, small patches of calcitic micrite that weather out as porcs. Bed 63 has a thickness of ca. $28 \mathrm{~m} .2 \mathrm{~m}$ above the base it is a pelmicrite with foraminifers and Clado. coropsis as well as calcite pseudomorphs after gypsum. $10 \mathrm{~m}$ above the base is a pelmicrite (packstone) with abundant Clado. coropsis, Caycuxia and some Thaunatoporella. The rock $18 \mathrm{~m}$ above the base is a pelmicrite (wackestone). The upper part of the massive bed 28 weathers back. whereas the well-bedded Reuchenette Formation above forms again a cliff.

\subsubsection{Section RG 384 Selzach SO, road through Lochbach gorge (pl.29)}

Ziegler (1956, pl.8) and Burkhatter (1989, fig. 2-12) have previously described and figured this outcrop. The section begins in the streambed east of the northern end of the tunnel. At the base there is $3.5 \mathrm{~m}$ of soft, blue-grey marl (bed 1, Effingen Member). Bed 3 is a blue-grey marl with lenses of limestone that are up to $13 \mathrm{~cm}$ thick and $70 \mathrm{~cm}$ wide. The lenses are made up of biopelmicrite to biopelsparite. Below they contain coral debris with a diameter of up to $1 \mathrm{~cm}$, and in the upper part there are flat colonies of what is probably Microsolena coral colonies. The lenses are therefore mini-bioherms. The stream flows along and over bed 4 that is a greenish-gray marl-lime mudstone with a thickness of $0.6 \mathrm{~m}$.

The hummocky lower bedding plane of bed 5 forms a high cliff above the stream. The hummocks are up to $0.5 \mathrm{~m}$ high and $3 \mathrm{~m}$ apart. This is the base of the Gunsberg Formation. At the base the rock is a bioruditic floatstone with large coral debris that are preserved as druses lined with calcite spar. There are also lenses of marly limestone, a fine-grained pelmicrite with about $5 \%$ fine-grained detrital quartz. $8.3 \mathrm{~m}$ above the base the whole rock is a fine-grained pelmicrite with about $5 \%$ quartz. The northernmost part of the tunnel (a length of $14.5 \mathrm{~m}$ ) is now lined with concrete. This concrete lining was not yet there when ZIECLER (1956, p. 78, section 27) measured the section. Beds 6 and 7 are fine-grained oosparite with large bioclasts of corals, gastropods and bivalves $17 \mathrm{~m}$ above the base of bed 7. Massive 
coral colonies reappear in the uppermost part of bed 8 (bed 6 of ZIEGLER 1956) where they are preserved as druses with a diameter of up to $8 \mathrm{~cm}$. Bed 9 is a saccharoidal and olive-green dolosparite with some rusty-brown peloids. There are abundant flat and massive coral colonies. These are bored by Lithophaga and recrystallized to coarse-grained calcitic sparite with some interspersed dolomite rhombs (bed 7 of ZIEGLER 1956, p. 78) Bed 12 has a thickness of $1.8 \mathrm{~m}$ and is saccharoidal. $1 \mathrm{~m}$ above the base about $80 \%$ of the rock is dolosparite with intermingled calcite spar. The calcite may be concentrated in patches that weather out as pores. The flat to massive coral colonies are intensively bored by Lithophaga and are about $10 \%$ of the rock volume (bed 9 of ZIEGLER 1956). Bed 15 is a saccharoidal oobiomicrite that depositionally dipped $20^{\circ}$ to the southwest. The cement is entirely dolomitized, whereas the ooids and bioclasts are replaced by an intergrowth of dolomite rhombs and xenotopic calcite spar. The last bed of the Gunsberg Formation is no. 18. The fresh grey-green, saccharoidal rock weathers redbrown. It is a bioruditic floatstone with a mostly dolosparitic groundmass and calcitic bioclasts. About $3 \mathrm{~m}$ above the road there is a coral bioherm.

The Steinebach Member has a thickness of only $3,4 \mathrm{~m}$ (beds 19 to 21 ). Bed 21 ( $1.2 \mathrm{~m}$ above the base) is an oopelsparite.

Hermatypic corals reappear in bed 22, the first bed of the Laufen Member, Bed 28 has a dark olive-green colour and is a lime-marl with some detrital quartz. It was completely dolomitized and then entirely dedolomitized (bed 17 of ZIEGLER 1956). Oncoids with a maximum diameter of $2 \mathrm{~cm}$ in bed 30 and $3 \mathrm{~cm}$ in bed 31 form $20 \%$ of the rock volume. These two beds are a local marker bed which also crops out at the upper end of the cliff west of Mt. Hasenmatt (section RG 380, bed 15).

The Verena Member begins with bed 33. An oosparite with inclined bedding forms the lower part of bed 34 . In the upper part of the bed the original texture is obliterated by intense dolomitization followed by complete dedolomitization of the rock. Bed 37 is an oobiopelsparite with cross-bedding in the upper part. There are solitary corals, nerineid gastropods, large bivalve clasts and colonies of Solenopora in life position. Some of these colonies still have part of their original, purple colour. Rounded bioclasts of corals and some nerineids with a diameter of as much as $4 \mathrm{~cm}$ form 30 to $50 \%$ of the oosparitic bed 40 . There are also rounded lithoclasts of oomicrite. In bed 42 the ooid content decreases from grainstone concentration at the base to zero at the top.

The lowest beds of the Reuchenette Formation (43 to 46) are well-bedded micrititic limestone with varying amounts of peloids. Bed 47 is massive lime mudstone.

\subsubsection{Transect Liesberg-Solothurn}

\subsubsection{Section RG 280 Liesberg BL,} clay pit of Ampthil (fig. 23, pl.30)

This section has been described by GrG (1990a, p. 179). It is refigured here in pl.30. The clay pit of Ampthil is also visible in the upper part of fig. 24 .

\subsubsection{Section RG 306 Liesberg BL, clay pis of Hinter Chestel and quarry of Chestel (fig. 24, pl.31)}

The section begins on the floor of the clay pit at a shear plane above the Dalle Nacrée Member of the early Callovian. The first unit is the Renggeri Member which is here only $29.5 \mathrm{~m}$ thick (bed 1). This bed appears in the field to be wholly homogenous and cannot be easily subdivided. No ammonites have been found, It is therefore probable that bed 1 represents the upper part of the Renggeri Member that contains few ammonites (cf. Gro 1990a, fig. 3).

The Sometan Member is a succession of homogenous bluegrey marl with bands of tough, ellipsoidal limestone concretions ("chailles") located at varying lateral distances from each

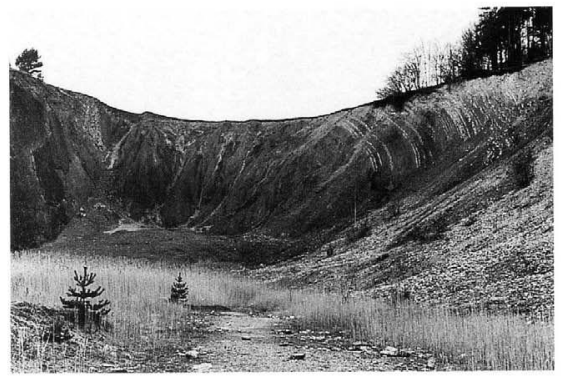

Fig. 23: Scction RG 280, clay pit of Ampthil, Licsberg BL, as seen from the east. Steeply dipping upper surface of Dalle nacrée Formation and thin Herznach Formation to the left (south), Renggeri Member in the center and banded Sornetan Member to the right. Photograph by A. L. Coe. See pl. 30. 
Fig. 24: Section RG 306, clay pit of Hinter Chestel and quarry of Chestel, Liesberg BL as seen from the east. The clay pit of Ampthil and the village of Liesberg are in the background. The ridge of the Hauplrogenstein Formation is to the left (south). The upper surface of the Calcaire roux sableux Mcmber forms the southern boundary of the pit (in the shade). The Dalle nacrée Formation (DN) is visible as a thin ridge within the pit. The Barschwil Formation (BAR) is between the ridge of the Dalle nacree Formation and the high ridge of the Chestel to the right which is formed by the St-Ursanne Formation (SUF). Compare with pl 31.

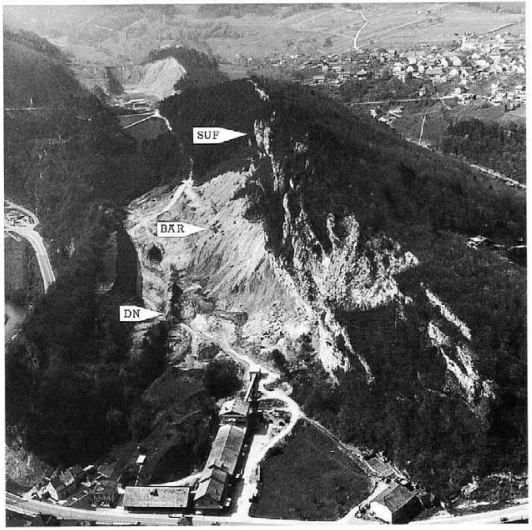

other. There are also continuous layers of marly limestone or limestone of the same colour. The base of the member is clearly defined by the base of the lowest band of limestone concretions (bed 2). The bulk of the nodules in this member ate microsparite that is indicative of diagenetic recrysiallization. The fine-grained bioclasts in the nodules are partly or wholly replaced by iron sulfide. The iron sulfide outside of the bicclasts occurs as flakes with a diameter from 400 microns down to submicroscopic size. The submicroscopic grains probably give the rock its characteristic blue-grey colour. Detrital quartz forms less than $1 \%$ of the nodules, and glauconite is rare. The continuous lavers of marly limestone and limestone are also made up of microsparite with bioclasts and iron sulfide. The bioclasts of bed 85 arc partly replaced by chert. Sponge spicula that are replaced by calcite are so abundant in bed 66 that it is a spiculite.

The Cardioceras (Cardioceras) cf. ashonense Arkell J 31550. found by A. L. Coe and identificd by D. Marchand, is from bed 66. This ammonite is of the Cordatum Subrone. The lower boundary of this subzone probably coincides in northwestern Switzerland with the lower boundary of the Sornetan Member, because no ammonite older than the Cordatum Subchron has ever becn found in sizu in this member. and no ammonite vounger than the Costicardia Subchron has been recorded from in situ in the Renggeri Member below. This means that more than the lower half of the Sornetan Member at Liesherg belongs to the Cordatum Subzone. The thickness of the Densiplicatum Subzone in this section cannot be evaluated exactly. The paucity of ammonites from this subzone in the Sornetan Member indicates that the subzone is here probably thin. The only ammonite of the Densiplicatum Subzone described from this section is the Gregoryceras (G.) tenuisculptum GYGI $\mathrm{S} 1874$ in the Muséc Jurassicn des scicnces naturelles at Porrentruy JU (see GYGi 1995, p. 8). The thickness of the lower part of the Antecedens Subzone in the upper Sornetan Member is greater judging of the number of ammonites known from this part of the section. ARKELL (1956, p.96) identified three Arisphinctes that had been figured by DE LoRIoL (1896, pl.6. fig. 2, pl. 7, fig. 1 and $\mathrm{pl} .8$, fig. 1) as being from the Antecedens Subzone (ARKELL 1925-27, Arkell 1935-48).

The sudden and massive advent of hermatypic corals at the base of bed 99 marks the beginning of the Liesberg Member. The corals of this bed are either thin. platy colonies or large soliIary specimens with a diameter of up to $3 \mathrm{~cm}$. The matrix is bluegrey marl like in the Sornetan Member, but it has a purple tinge. The limestone nodules in this marl have an irregular shape unlike in the Sornetan Member. There are serpulids that are partially white from silicification. A.L. Coe found a large Perisphinctes (Arisphinctes) sp. in the lower part of bed 101 
whilst completing fieldwork with the author. This is the only ammonite that has ever been recorded from in situ in the Liesberg Member. The most abundant fossils of the Liesberg Member apart from corals are large pectinid bivalves, serpulids, small calcareous sponges as well as the echinoids Glypticus hieroglyphicus (GoLDruss) and Paracidaris florigemma (PHILlups) (mostly spines). Crinoids are mainly represented by Liliocrinus munsterianus (D'ORBIGNY) and these can be as much as $1 \mathrm{~m}$ tall. In the majority of these specimens only the rootstock is preserved in which very often the original purple dye of the animal is preserved (so-called fringelite, Blumer 1951, p. 1052). The corals are by far the most abundant fossils of the member. In bed 106 the platy colonies become thicker, and massive colonies appear.

The base of the St-Ursanne Formation is marked by bed 107 , a limestone with indistinct inclined bedding. It is a bioarenitic oncomicrite (packstone) with a partially dolomitized and entirely dedolomitized matrix. The diameter of the oncoids is less than $5 \mathrm{~mm}$. There are massive coral colonies with a diameter of up to $30 \mathrm{~cm}$. The abundance of the oncoids diminishes in bed 108 whereas ruditic coral clasts increase in abundance. In bed 109 the rock becomes an oosparite with only a few, small oncoids and solitary corals. Bed 110 is a pure oosparite. Beds 107 to 110 represent the Delémont Member. Bed 111 is a micrite that is mostly porous and white, but it can be locally well-cemented and then has a beige colour. The micrite contains up to $10 \%$ arenitic bioclasts. To the west and to the east of the quarry there are coral bioherms in this level. Bed 111 is $35.5 \mathrm{~m}$ thick. In bed 112 the micrite is well-cemented and yellowish white. There is again a coral bioherm in bed 113 with branching and massive coral colonies as well as nodules of Solenopora with a pale violet colour. The section ends with bed 120 , just short of the upper boundary of the St-Ursanne Formation.

The Vorbourg Member forms a distinct ridge of well-bedded limestone northwest of the quarry in the forest. This ridge becomes very subdued north of the quarry, still in the forest. Here it contains a conspicuous stromatolite with dewatcring cracks and birdseye pores that was figured by GYGl $(1992$, fig. 10, PS Gy 4558).

\subsubsection{Section RG 398 Liesberg BL. limestone quarry (pl.32)}

The section begins north of the cantonal road at point 382 . Bed 2 is a $0.8 \mathrm{~m}$ thick pelmicrite with detrital quartz of the Roschenz Member. The upper bedding plane is a hummocky crosion surface with a relief of up to $15 \mathrm{~cm}$. Bed $3 \mathrm{a}$ is a micrite with detrital quartz and rootlets (fig. 25, PS Gy 4561). The rootlets are replaced by calcite spar and lined with limonite (TS Gy 6514). In bed $3 \mathrm{~b}$ there is a tidal channel that is at least $0.5 \mathrm{~m}$ deep. The upper bedding plane of bed 16 is a hummocky erosion surface. Bed 17 is a pelsparite with parallel lamination. This seems to be a sediment from the lower beach. Bed 18 is a cross-bedded pelsparite. Behind the crusher building the upper $0.9 \mathrm{~m}$ of the bed is a beige limey marl with wine-red patches.

The base of the Hauptmumienbank Member is marked by bed 19. The lower bedding plane is a planed erosion surface. The rock is an oncolitic wacke-to grainstone. The oncoids that have a diameter of up to $12 \mathrm{~mm}$ make up $5 \%$ of the rock. At the base

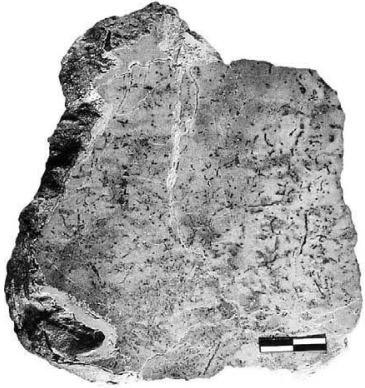

Fig. 25: Micrite with some detrital quartz and rootlets. Section RG 398. Liesberg BL. cantonal rosd near former cement works, bed $3 \mathrm{a}$, Rdachenz Member. PS Gy 4561. sec pl. 32 . Scale bar is $2 \mathrm{~cm}$.

of bed 21 about $30 \%$ of the rock are oncoids with a maximum diameter of as much as $5 \mathrm{~cm}$. Nerinean gastropods, Cladocoropsis and coral debris are in the core and some Bacinella in the crust of the oncoids (PS Gy 4572). The matrix is biomicrite. Cladocoropsis form rods with a diameter of 4 to $5 \mathrm{~mm}$ and a length of more than $3 \mathrm{~cm}$ in the upper part of the bed where large burrows form about $10 \%$ of the rock volume (TS Gy 6524). The upper bedding plane is a hummocky erosion surface with adhering ostreids.

The beds 24 and 25 are equivalents of the Oolithe Rousse Member. Bed 24 is a marly oomicrite with micritized and partly dolomitized, then dedolomitized, rusty-brown ooids in a dedolomitic, microsparitic matrix.

The first bed of the Laufen Member is no. 26, a marl-limestone (wackestone) with peloids and ostreids that have oncolitic crusts. Bed 28 is very fossiliferous: there are rhynchonellids (Septaliphoria), ostreids, Cycloserpula and nerineid gastropods with an oncolitic crust (PS Gy 4576). The rest of the member is mostly micrite that was partly dolomitized and then entirely dedolomitized. It is in the upper part of this member that W. Hugli found the large Paracenoceras ef giganteum (D'OragnY) J 31651 on the roadside south of Cholplatz to the east of the quarry.

Bed 49, a peloidal packstone, is at the base of the Verena Member. $1 \mathrm{~m}$ below the top of the oosparitic bed 50 there is a $0.2 \mathrm{~m}$ thick layer where nerineid gastropods form up to $40 \%$ of the rock volume. The oosparitic texture of bed 51 is hardly visible on a freshly broken rock surface where the interstices of the micritized ooids are filled with fine-grained peloids. Bed 53 was originally an oomicrite with micritized ooids. Then the matrix was completely dolomitized and then dedolomitized. There are 


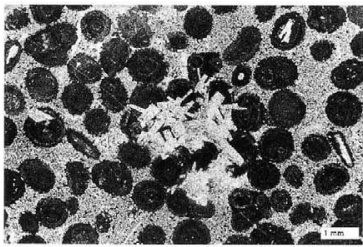

Fig. 26: Oolite with dolomitized and dedolomitized cement. Calcite pseudomorphs after sulfate in the center. Section RG 398, Licsberg BL limestone quarry of the former cement works, bed 53, Verena Member. Thin section Gy $6532, \mathrm{pl} .32$.

pseudomorphs of calcite after sulfate (fig. 26) like in the oosparite of bed 55 . Bed 57 is a conspicuous white band in the quarry wall. It is a porous, chalk-like biomicrite. The lower part of bed 58 is a pelsparite with Trichites and Diceras as well as with nodules of Solenopora with a diameter of up to $15 \mathrm{~cm}$.

The Reuchenette Formation forms the uppermost quarry wall above the sccond terrace. Bed 60 is a beige micrite that breaks along smooth planes. Bed 66 is an oosparite with micritized ooids. The micrite of bed 70 was partly dolomitized by tiny rhombs, then dedolomitized. Bed 79 is a biosparite with a corroded upper bedding planc. The lower part of bed 80 is a fine-grained pelsparite. The section ends with this bed at the upper edge of the quarry.

\subsubsection{Section RG 402 Röschenz BL, road to Miali ( $p$ !. 33)}

Bed 1 is a pelsparite and bed 2 is a biopelsparite of the upper StUrsanne Formation. The lower part of bed 3 is oosparitic and the upper part a pelsparite. $4 \mathrm{~m}$ above the base of the bed are massive coral colonies with a diameter of up to $20 \mathrm{~cm}$. The upper bedding plane is a hummocky hardground which is covered with a limonitic crust. Below the crust the rock has a rustybrown colour to a depth of at least $5 \mathrm{~cm}$. The uppermost $5 \mathrm{~mm}$ are an overcompacted peloidal packstone. The pore volume is reduced to almost zero by intergranular solution.

The base of the Vellerat Formation is marked by a pale winered, soft marl that has a thickness of only $5 \mathrm{~cm}$ (bed 4). Bed 7 is a peloidal packstone (pelmicrite) with about $5 \%$ fine-grained detrital quartz, this is the facies of the Vorbourg Member. Bed 13 is a limey marl with biopelmicrite concretions that contain about $10 \%$ detrital quartz. The top of the bed is micritic limestone that is covered with a limonitic crust. Bed 21 is composed of a well-laminated stromatolite with birdseye pores. Bed 23 contains stromatolites, the lamination of which is mostly oblitcrated by bioturbation. Angular lithoclasts occur with a diameter of up to $25 \mathrm{~mm}$. Some of them are blackened.

The Röschenz Member is a very varied succession of limestones and marls. This is the only surface section where this member was completely visible during a few days in August 1983. The content of fine-grained detrital quartz may be as much as $30 \%$ as in bed 36 or 52 . The mean grain size of detrital quartz and feldspar in these beds is only 50 microns. Bed 57 has a thickness of $0.7 \mathrm{~m}$ and is entirely made up of stromatolites (PS Gy 4668 , TS Gy 6612). Bed 67 is a quartz biopelsparite. A very fine-grained, partly cross-bedded oosparite occurs in bed 68 . Bed 71 is a soft, yellow-brown marl with little detrital quart?. It top is the top of the Röschenz Member.

The base of the Hauptmumienbank Member is marked by the oosparite with micritized ooids of bed 72. The lower part of bed 75 is an oolitic grainstone. At the top the bed is an oncolite with a biopelmicritic matrix. The oncoids form about $30 \%$ of the rock and have a diameter of up to $25 \mathrm{~mm}$.

Beds 77 and 78 of the lower Laufen Member contain a few percent of fine-grained detrital quartz. Bed 80 includes about $25 \%$ oncoids with a diameter of up to $3 \mathrm{~cm}$. The oncoids are intensively bored by the bivalve Lithophaga. The primarily micritic matrix is partly dolomitized and completely dedolomitized.

\subsubsection{Section RG 399 Barschwil SO. landslide west of Vögeli farm (fig. 27, pl.34)}

The lower part of the section (Sornetan and Liesberg Members) has been measured in the westernmost gully of the landslide and the St-Ursanne Formation using a rope in the central part (fig. 27).

The Sornetan Member is a homogenous, blue-grey marl with bands of limestone concretions. These nodule bands may pass laterally into continuous limestone beds. The nodules of bed 4 are made up of microsparite with flakes of iron sulfide that may be as large as 400 microns. The limestone bed 10 is also microsparite with flakes of iron sulfide and about $1 \%$ of detrital quartz with a mean grain size of 40 microns. There are a few percent of sponge spicula in bed 46 , together with Thumannella oburita (Defrance) (= thurmanni Voliz), pectinids, Pleuromya and Pholadomya exaltata AGASSIZ as well as cardioceratid and perisphinctid ammonites (see GyGl \& Marchand 1993, pl. 1, fig, 6, pl. 2, fig. 2 and pl.3, fig. 5). In the nodules of bed 113 there are small chert concretions with a diameter of up to several centimetres and colonies of Serpula (Cycloserpula) sociolis GoldFuss which are infilled with chert.

Bed 115 marks the base of the Liesberg Member. This bed is a microsparitic marly limestone with millimeter-size chert nodules, partly silicified bioclasts and Serpula (Cycloserpula) socialis Goldruss. Bed 116 is a grey marl with limestone concretions that have a knobby surface, The nodules are distributed irregularly, and not in distinct bands as in the Sornetan Member. Some of the fossils in the nodules are partly silicified. There are calcareous sponges, Cycloserpula. Glypticus hieroglyphicus (Got.dfuss), spines of Paracidaris florigemma (PHILIPS) and a profusion of hermatypic corals that often have the shape of a flat bread loaf.

Beds 118 to 136 are a succession of marls and limestones The limestones gradually become thinner and argillaceous from west to east or grade laterally into marl within the outcrop. This is a locality where the lower St-Ursanne Formation grades laterally into the Liesberg Member. It is noteworthy that 


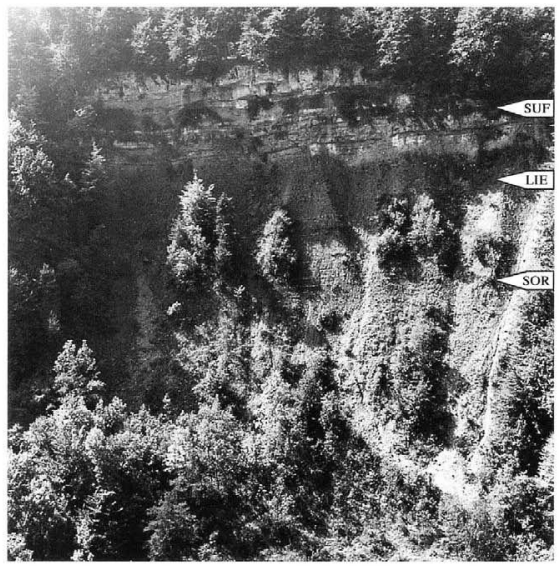

Fig. 27: Upper part of the landslide west of Vögeli farm, Bärschwil SO as seen from the north. The section RG 399 begins with the Sornetan Member of the Barschwil Formation and ends with the lower St-Ursanne Formation. Eastsoutheast is to the left and westnorthwest is to the right. Compare with pl. 34 .

the majority of the flat colonies of what is probably lsastraea at the base of bed 118 are overturned. On the other hand, a rootstock with its original purple colour of Liliocrinus munsterianus (D'ORBigny) has been found in life position in bed 121. This and other observations are an indication that no appreciable amount of sediment has been eroded and redeposited by currents during storms. It is most probable that the coral colonies have been overturned by animals in search of food. The base of the typical massive, pure limestone of the St-Ursanne Formation is marked by bed 137.30 to $50 \%$ of this rock are coral colonies with the shape of bread loafs. This is a coral bioherm. Bed 138, the uppermost of the outcrop, is an oncolitic biopelsparite.

\subsubsection{Section RG 400 Corban JU, gorge northeast of La Providence farm (pl.35)}

The section begins at the end of the road with the Grellingen Member of the St-Ursanne Formation. Bed 1 is a biomicrite with coral colonies that have the form of small bread loafs. The bed forms a cliff facing north. The coral colonies in beds 2 and 3 are platy, branching and massive. Bed 4 is again a biomicrite. The massive bed 5 is probably a bioherm that contains massive and coarsely branching coral colonies,

The base of the Tiergarten Member is transitional and is in the lower part of bed 6. Most of this member is an oolitic grain- stone which is often cross-laminated. The upper surface of bed 10 is a planar hardground with a brown limonitic crust. Bed 11 is a bioherm with platy, massive and branching coral colonies. The upper surface of bed 17 is covered with ostreids and other bivalves, this forms another hardground.

Beds 18 to 24 are peloidal and bioarenitic grainstones and are assigned to the Günsberg Formation. Bed 25 marks the base of the Vorbourg Member of the Vellerat Formation. This is a lime mudstone with birdseyes that is probably a thrombolite. The stromatolitic limestone with rootlets of bed 26 is figured in GyGi (1992. fig. 13, PS Gy 4621).

The lower part of the Röschenz Member is sparsely exposed along the creek. The member is as always a very varied succes. sion of mainly arenitic limestones with some thin intercalations of marl. Fine-grained detrital quartz and feldspar are common, mainly in beds 41,48 and 50. Bed 50 is a quartzpelsparite that is depicted in fig. 15. Oncoids occur in beds $43,44,81$ and 88 . Beds 55 and 60 are stromatolites. The upper bedding plane of bed 60 is covered with a carbonate-rich, pale wine-red crust. The hummocky crust is a hardground.

The Hauptmumienbank Member begins with bed 92, a peloidal bioarenitic wackestone. There are numerous clongate druses with calcite in this bed which were probably originally large nerineid gastropods. The oncoids of bed 93 have a diameter of up to $12 \mathrm{~mm}$. They are embedded in a pelsparitic matrix. 


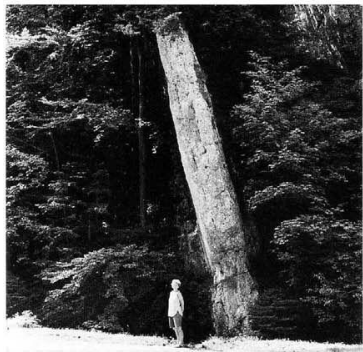

Fig. 28: Steeply dipping Hauptmumienbank Member (bed 32) in section RG 404. Mervelier JU, gorge of the Scheulte river, western flank. Sce pl. 36 .

In the upper part of bed 94 the oncoids grew to a diameter of $3 \mathrm{~cm}$ and form 10 to $20 \%$ of the pelsparitic rock. The upper bedding plane of no. 94 is corroded and bored. It is covered by abundant ostreids that are sometimes also perforated. The rock. surface and the ostreids are covered by a limonitic crust with a thickness of $1 \mathrm{~mm}$.

Oncoids have also been found in the beds 95 to 97 of the lower Laufen Member. Some coids in bed 95 indicate that it is the equivalent of the Oolithe Rousse Member. The oncoids in bed 96 reach a size of $25 \mathrm{~mm}$ and comprise about $30 \%$ of the rock. Bed 101 is a partly dolomitized and then completely dedolomitized oomicrite with ostreids and Cycloserpula. Bed 106 , an oosparite, has also been partly dolomitized and then entirely dedolomitized.

Bed 109 is massive and forms the base of the Verena Member. It is an oosparite that is partly reerystallized (dedolomite). The oosparite of bed 111 was thoroughly dolomitized and has then been completely dedolomitized. Part of bed 112 is oosparite ( $2.2 \mathrm{~m}$ above the base). $3 \mathrm{~m}$ above the base of bed 113 there is gypsum with a high carbonate content. The gypsum crystals have a diameter of 50 to 500 microns and make up at least $50 \%$ of the rock. The section ends with this bed.

\subsubsection{Secrion RG 404 Mervelier JU, gorge of the Scheulte river, western flank ( $p l .36$ )}

The section begins with the lower St-Ursanne Formation about $40 \mathrm{~m}$ north of the road at the base of the high cliff that is formed by bed 1 . This is a biomicrite with platy coral colonies and spines of sea urchins. Beds 1 to 3 can be subdivided into thinner beds. Bed 4 is massive. It is probably a bioherm with a biomicritic matrix that in some places becomes biosparitic (TS Gy 6634). The coral colonies are platy, massive or branching. No zonation can be recognized. The upper boundary of the unit is a conspicuous parting. Bed 5 is again massive and probably a bioherm. $3.5 \mathrm{~m}$ above the base there is an oobiosparite to -micrite. Solitary corals are abundant at the base and $4.5 \mathrm{~m}$ above the base of the unit. The matrix of the bioherm is mostly biomicrite (TS Gy 6636).

The Gunsberg Formation is characterized by two successions of coral limestone to arenitic limestone. The base of the formation is marked by a distinct boundary between the pure limestone of bed 7 and a marly seam at the base of bed 8 . Bed 9 is a biomicrite with ruditic bioclasts of corals and ostreids that has been partly dolomitized and then completely dedolomitized. Bed 15 is an oosparite. The coral growth resumed in bed 16 which is a biosparite with ruditic bioclasts of corals Beds 18 and 19 are formed by a coral bioherm with a biomicritic matrix. $4.5 \mathrm{~m}$ above the base of bed 18 more than $50 \%$ of the rock is composed of platy coral colonies each with a thickness of about $1 \mathrm{~cm}$. Bed 19 weathers with a knobby surface. About $50 \%$ of this unit are massive coral colonies. Bed 21 is a coarsely-grained arenitic to ruditic biosparite. There are relatively few oncoids with a diameter of up to $8 \mathrm{~mm}$ in the oobiomicritic bed 24 . The uppermost Gunsberg Formation is a sandy calcarenite with inclined bedding (bed $31 \mathrm{~b}$ ).

The Hauptmumienbank Member is represented only by the bed 32 . This projects subvertically like a plank south of the creek (fig. 28). In the lowermost $40 \mathrm{~cm}$ of the bed there are oncoids with a maximum diameter of $1 \mathrm{~cm}$ that do not form more than $10 \%$ of the rock. Small nerineid gastropods are often in the core of the oncoids. Ostreids occur in the biopelmicritic matrix. There are hermatypic corals in the middle of the bed. The uppermost part of the bed is a fine-grained oolitic grainstone with rounded lithoclasts of lime mudstone.

The Laufen Member begins with a quartz-bearing pelmicrite (bed 33). Bed 44 contains about $10 \%$ oncoids up to $6 \mathrm{~mm}$ in diameter. Bed 50 is a peloidal-oncolitic rudstone. In bed 53 the pale yellow oncoids with Bacinella form 20 to $30 \%$ of the rock and have a maximum diameter of $5 \mathrm{~cm}$. The matrix is a rusty brown bjosparite with a dedolomitized cement. The upper boundary of the Laufen Member is an even, very conspicuous bedding plane on both sides of the Scheulte river.

The lowest unit of the Verena Member is the massive bed 66 that forms a high ridge which overhangs above the southern bank of the Scheulte River. Most of the rock was apparently originally an oomicrite (packstone). The matrix has been almost totally dolomitized, then entirely dedolomitized. The result of the process is that the micritized ooids are only clearly visible on weathered surfaces. Bed 68 is $12 \mathrm{~m}$ above the base a pelsparite with Cayeuxia and calcite pseudomorphs after sulfate. Bed 69 is a massive micrite and must therefore be assigned to the upper Verena Member.

A good outcrop of the lowermost Reuchenette Formation is to the south of the Scheulte River. Bed 70 is micrite with patches of pelmicrite. Flat-laminated stromatolites are in bed 72 . Bed 75 is an apparently dedolomitized microsparite with some percent of fine-grained detrital quartz. Above the massive bed 76 the outcrop becomes poor. The following thickness of about $15 \mathrm{~m}$ of thickly-bedded limestone is partly covered by soil and vegetation. 


\subsubsection{Section RG 406 Vermes U.}

ravine southeast of La Kohlberg farm (pl. 37)

The section has not been measured in full detail, because it is incompletely exposed, cliffs under waterfalls are inaccessible and a part of it is repeated by a folded overthrust that has already been noted by PFIRTER (1982, p. 91, section 601,p. 92). The thrust plane is not visible. Therefore, the section has been measured and the beds have been numbered as if there was no tectonic complication (pl.37)

The section begins north of the road from Vermes to Raymontpierre castle in the western branch of the ravine of the Bie des rues creek. Ca. $15 \mathrm{~m}$ from the road there is a patchy outerop of the Renggeri Member in the creek, this is followed by two outcrops of the Sornetan Member. The section drawn in pl.37 begins with the hummocky base of the Pichoux Formation that is encrusted with limonite.

The lower half of the Pichoux Formation (bed groups 1 to 4) is relatively thin-bedded. The individual, mostly biomicritic beds have a thickness of between 10 and $80 \mathrm{~cm}$. In the middle of the bed group 2 there is the spiculite which is represented in fig. 11 (TS Gy 7582). Sponge spicula and peloids are abundant in bed 3. The bedding of beds 5 and 6 of the upper Pichoux Formation is thicker. The rock is biopelmicrite with sponge spicula in TS Gy 7585. High ridges are formed by bed 5 on both sides of the ravine. The top of the Pichoux Formation is not easily recognizeable.

The base of the Guinsberg Formation is assumed to be where detrital quartz begins to form more than a few percent of the rock (TS Gy 7588, pl.37), this is when it can be detected in the field by scratching a hammer. Bed 7 is a pelmicrite with much detrital quartz. There are two marly intercalations in the pelmicrite with some detrital quartz of bed 8 . Silicified bioclasts and the first hermatypic corals occur in bed 9 which forms the second waterfall (as counted from the top) of the creek. Bed 10 crops out along the old road and contains small chert nodules with a diameter of up to $5 \mathrm{~cm}$. A triple waterfall is formed by bed 11 that is an oosparite $8.5 \mathrm{~m}$ above the base. At the base of the waterfall, the third from the top. a thickness of $6.2 \mathrm{~m}$ of strata is covered by pebbles and debris. Then there is a forth, small waterfall and another break in the section because of debris in the creek. Downstream follow an oolite and the oncolite of the Hauptmumienbank Member. The Laufen Member forms a high. perpendicular waterfall. At the base of this fifth waterfall there is a thrust plane that repeats the section.

The section of the middle Gunsberg Member resumes at the foot of the fifth waterfall after a short break of $1.5 \mathrm{~m}$ that is covered with limestone debris. Bed 32 is a bioclastic rudstone with massive coral colonies in life position. Above is a coral bioherm (bed 33) that forms the sixth waterfall. It is a boundstone with a quartzose micritic matrix in the lower half (TS Gy 7596) and contains biopelsparitic grainstone in the upper half (TS Gy 7597). The beds 34 to 38 in the creek are laterally replaced by another bioherm with massive coral colonies that is intersected by the road. The wavy laminated stromatolite of bed 47 is conspicuous on the right bank of the creek where it forms a projection. Bed 48 is another stromatolite with mostly even lamination. The base of bed 49 is very uneven. Bed 49 is a conglomerate with blackened lithoclasts in a pelmicritic, slightly quartzose matrix
(TS Gy 6677). Many of the clasts are laminated bits of a stromatolite. Blackening of the clasts and abundant nerineid gastropods are evidence that the deposit is marginal marine (GYG \& Persoz 1986, fig. 5, PS Gy 4735, see also Strasser \& Davaud 1983). The upper bedding plane is a planed erosion surface that intersects the clasts. This surface is encrusted with large, thickshelled ostreids (D in fig. 5 by Gygi \& Persoz, 1986). The bedding planc and some of the ostreids are bored. Above this eharacteristic bedding plane are $8.5 \mathrm{~m}$ of marl that is mostly covered with talus.

The Hauptmumienbank Member begins with the peloidal wackestonc of bed 51 in which massive coral colonies form a densely colonized biostrome. The lowermost two beds of unit 52 , both $0.25 \mathrm{~m}$ thick, are a bioclastic rudstone. Above, the rock is a cross-bedded calcarenite (oosparite, TS Gy 7599). Unit 53 is indistinctly and thickly bedded. At the base it is a peloidal/ooidal wackestone. In the middle are about $10 \%$ oncoids with a diameter of up to $25 \mathrm{~mm}$. Some of the oncoids have a drusy cavity in the core and one includes a Cladocoropsis colony. Paratrgonina occur in the micritic matrix as well as calcite pseudomorphs after gypsum.

At the base of the Laufen Member there is a soft, yellowishbrown marl with detrital quartz and a thickness of $0.5 \mathrm{~m}$. It is only visible beside the old road. Bed 55 above is a limestone with a micritic matrix that includes oncoids and some massive coral colonies. Bed 56 is massive and forms the upper part of waterfall no. 7. The upper Laufen Member is oolitic and has been measured along a footpath that ends beside the upper edge of waterfall 7. The top of the member is marked by the uppermost distinct parting at the top of bed 74 .

The Verena Member crops out mostly in the creek. Bed 75 is an oolite with micritized ooids in a dedolomitized matrix that is partly micritic and partly sparitic. The upper part of bed 76 is an oomicrite with micritized ooids that has been partly dolomitized and then entirely dedolomitized. The upper part of bed 77 is a pelsparite with a few dedolomite rhombs. The middle part of bed 78 is an oncomicrite. In the middle of bed 79 there is a pelsparite. $2 \mathrm{~m}$ below the top of this bed the rock is a dedolomitized pelmicrite. The top of the Verena Member is indicated by a distinct parting that is best seen in the eastern branch of the creek about $70 \mathrm{~m}$ to the east.

At the base of the Reuchenette Formation there is pure micrite (TS Gy 6685). Further up the content of peloids and bioclasts increases. The measuring of the section ends at the top of waterfall 11 which is the lowermost in the ravine.

\subsubsection{Section RG 356 Grandval BE. landslide of La Morte Roche (fig.29, pl.38)}

The measurement of the section began ca. $80 \mathrm{~m}$ to the west of the gully below the western part of the landslide, at the foot of the cliff of the Pichoux Formation (fig. 29). The contact with the underlying Sornetan Member is not exposed. Bed 2 is a spiculitic biomicrite with about $1 \%$ fine-grained glauconite. Above is relatively thinly-bedded micrite of the lower Pichoux Formation. The section, beginning with bed 17 , continues in the western gully. Beds 24 to 34 are more or less marly. The upper part of the Pichoux Formation has a much thicker bedding than the lower part and it is mostly pure micrite (TS Gy 6324, $\mathrm{pl} .38$ ). 
The top of the Pichoux Formation is a distinet bedding plane.

The Wildegg Formation (Eftingen Member) is about $100 \mathrm{~m}$ thick. The middle part is covered by a small landslide and the upper part by talus from the Gunsberg Formation above. The Wildegg Formation is a succession of blue-grey marl with intercalations of marly limestone and limestone. Some of the micritic limestone beds (126. TS Gy 6325) and probably also the marl contain several percent of very fine-grained detrital quarty. In the upper part of the formation there are bands of carbonate nodules in marl that resemble the Sornetan Member. The fossils of the Effingen Member are also similar: mainly ammonites and bivalves. Bed 224 is a laminated quartz siltstone (TS Gy 6328). A lumachelle of mainly small ostreids in a dedolomitized micritic matrix forms bed 226 (TS Gy 6329).

The Gunsberg Formation begins with greenish-grey, slightly marly biopelmicrite with some detrital quartz (TS Gy 6331). Embedded in this sediment are small coral bioherms with platy and massive coral colonies (bed 228). The small bioherms are superimposed (bed 230). At the base of a vertical cliff formed by the Günsberg Formation there is a slightly quartzose biopelsparite (bed 231). The cliff is about $35 \mathrm{~m}$ high and inaccessible. It has not becn measured, because this unit is casily accessible $2.5 \mathrm{~km}$ to the east at Gansbrunnen (section RG 430,pl.40).

\subsubsection{Section RG 429 Welschenrohr SO. gorge south of Harzergraben (pl.39)}

The section begins $50 \mathrm{~m}$ west of the bridge north of the streambed. The Effingen Member is represented by the bluegrey marls and limestones of beds 1 to 7 .

The Gunsberg Formation begins with a thin bed $(5 \mathrm{~cm}$, no. 10) of marly, bioruditic floatstone with abundant branching corals, ostreid bivalves, serpulids and a few percent of finegrained, angular detrital quartz. Bed 12 contains about $10 \%$ detrital quartz and is a biopelmicrite with rhombs of ferroan dolomite and nodules of iron sulfide up to $5 \mathrm{~mm}$ in diameter. There are massive coral colonies in beds 15 and 18, but no bioherm was found. The bulk of the Günsberg Formation is biopelsparite (bed 22) and oobiopelsparite (bed 23). In the upper part of bed 23 there are coral bioclasts up to several centimetres in diameter. Bed 24 contains grapestones and some small oncoids.

The first bed of the Steinebach Member is a massive, yel lowish-white oosparite which is very well-sorted. It weathers back as a hollow. Bed 29 is an oosparite that has been partly dolomitized and then totally dedolomitized. The surface of the micritized ooids is indented by primarily dolomite rhombs There is some detrital quartz with the unusually large grain size

Fie. 29: Section RG 356 Grandval $B E$, landslide of Morle Roche as seen from the north. The cliff below is the upper part of the Pichoux Formation. The Wildegg Formation (Effingen Member) is in the center. Above is the cliff of the lower Günsberg Formation. See pl. 38 .

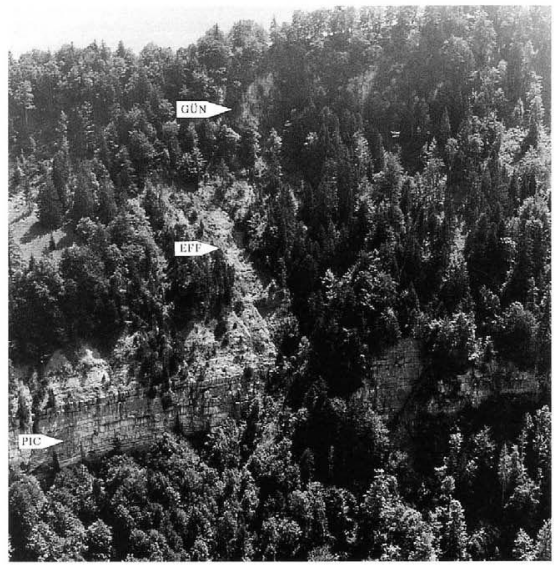


of up to 250 microns within the ooids. The upper bedding plane of bed 30 is corroded. The bed itself has a knobby weathered surface. The ooids as well as the groundmass have recrystallized as microsparite. The rock was apparently totally dolomitized and then dedolomitized. The upper bedding plane is probably an emersion surface.

The Laufen Member forms a high ridge, and bed 34 forms the principal waterfall in the gorge. Bed 32 is a characteristic, very tough limestone. Its groundmass and some of the peloids have partly been dolomitized and were then entirely dedolomitized. About $25 \%$ of the rock are oncoids with a diameter of up to $25 \mathrm{~mm}$ (PS Gy 4945). Bed 35 is an oosparite with some large oncoids of Bacinella, the cores of which are composed of pseudomorphs of calcite after calcium sulfatc. It has been partly dolomitized and then completely dedolomitized. The upper bedding plane is a palcokarst surface from which pockets with a filling of clay reach as tar as $1 \mathrm{~m}$ down to the base of the bed.

The Verena Member begins with the oosparite of bed 36 . The rock is oosparite to the top of bed $38.1 \mathrm{~m}$ above the base of the massive bed 39 there is microsparitic dedolomite with patches of up to $1 \mathrm{~cm}$ in diameter of coarse calcite spar that are probably calcite pseudomorphs after sulfate. A sample from $1.8 \mathrm{~m}$ above the base of bed 39 is micrite that has been replaced by about $50 \%$ of coarse-grained dolomite rhombs, it then has been completely dedolomitized (fig. 30). The upper part of bed 39 is pure micrite. The upper boundary of the member is an even, well-defined parting.

The lowest bed (no. 40) of the Reuchenette Formation is $0.8 \mathrm{~m}$ thick. It is a succession of plates and laminae of micrite that contains birdseyes $0.15 \mathrm{~m}$ above the base of the bed. The base of bed 41 is a stromatolite with dewatering cracks (PS Gy 4957). The lamination is fine and indistinct and can only be seen in the upper part of the thin section Gy 7139. Bed 50 is also indistinctly laminated and contains birdseye pores that are filled with calcite spar. The upper bedding plane is rough and is covered with a yellowish limonite crust. The lowermost $20 \mathrm{~cm}$ of bed 52 are a pelsparite with lithoclasts of micrite with a diameter of as much as $2 \mathrm{~cm}$. Smaller lithoclasts are grey to black. The

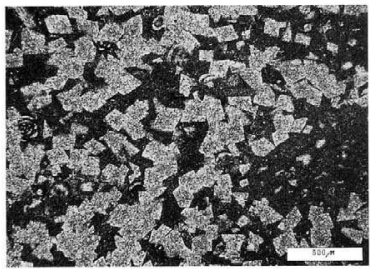

Fig. 30: Mierite with dedolomitized rhombs. Section RG 429, bed 39b, middle Verena Member. gorge south of Harzergraben, Welschenrohr SO. Thin section Gy 7136, pl.39. upper part of what is preserved of the Reuchenette Formation is mostly pel-and oosparite.

\subsubsection{Secions RG 430 and 431 Gänsbrunnen SO. cantonal road and quarry ( $p l .40$ )}

The section RG 430 begins at the southern end of a retaining wall along the cantonal road about $80 \mathrm{~m}$ south of the main building of the railway station of Gänsbrunnen. In bed 2 of the lower Günsberg Formation there is a coral bioherm above the road. Another small coral bioherm has been found in bed 10 west of the Raus brook directly north of the exit of the deviation tunnel. Most of the limestone beds in the succession 1 to 10 are more or less dolomitic. Bed 11 is a coral bioherm that is intersected by the road. Beds 1 to 11 are the "Crenularis-Schichten" of Buxtorf (1907, p. 54). Neither the facies nor the agc of these beds have anything to do with the Crenularis Member of Canton Aargau which is of Bimammatum Age. Above is a thick succession of peloidal and oolitic grainstone (beds 12 to 16). The uppermost part $(0.5 \mathrm{~m})$ of bed 16 is an oomicrite (packstone) with subangular lithoclasts of the same material as the matrix that may have a diameter of more than $10 \mathrm{~cm}$. The clasts are darker than the beige matrix and some are black. The upper bedding plane of no. 16 is a limonitic crust which is covered with a $5 \mathrm{~mm}$ thick layer of marl. The sandy marl of bed 25 is locally as black as coal and contains lignite. At the top of the stromatolitic bed 29 are rounded black pebbles with a diameter of up to $2 \mathrm{~cm}$.

The lowermost unit of the Balsthal Formation is the massive bed 35 which is now recognized as being the Steinebach Member. This is a yellowish-white oosparite which resembles the Verena Member (TS Gy 7170). ZregLer (1956, p. 96) assigned the unit to the Verena Member, and GvGI (1969,pl. 19. fig. 2, section 5) followed him. This error goes back to BUXToRF (1907, p. 54).

The Laufen Member is incomplete. The first bed, no. 36, contains about $20 \%$ of intensely bored oncoids with a diameter of up to $3 \mathrm{~cm}$ in a biomicritic matrix. There are also some hermatypic corals that are partly dissolved. Oncoids of the same size are about $15 \%$ of bed 37 . They have often a druse filled with calcite in the interior. The matrix of this bed is biopelmicrite. Dedolomitized rhombs occur in bed 40 . Beds 41 to 43 are pure micrite. The upper part of the Laufen Member is cut off by an overthrust plane that dips steeply to the south. Above is a sheared rone that is more than $4 \mathrm{~m}$ thick. A thickness of $2.9 \mathrm{~m}$ of greenish-grey dedolomitized limestone of the uppermost Laufen Member crops out south of the sheared zone. This is overlain by fractured limestone of the Verena Member that forms the principal ridge above the quarry.

Buxronf (1907, p. 58) assigned the whole of the Verena Member to the Kimmeridgian (in the sense of a formation) and stated that the total thickness of the Kimmeridgian limestones was $130 \mathrm{~m}$. The Reuchenette Formation has been measured to be less than $13 \mathrm{~m}$ thick in the section RG 431 ( $\mathrm{pl}$. 40). The thickness of the fractured Verena Member between the top of the Laufen Member and the shear plane at the foot of section RG 431 cannot be measured, but it is of the order of $35 \mathrm{~m}$. The thickness of the Verena Member measured in the neighbouring section RG 429 (Welschenrohr) is $32.3 \mathrm{~m}$. The minimum primary thickness of this member in section RG 431 must then be about $35 \mathrm{~m}$. The maximum is less than $60 \mathrm{~m}$, because $57.2 \mathrm{~m}$ is the 
greatest thickness (section RG 404, Mervelier JU, pl.36) that has been measured anywhere in a tectonically undisturbed section of the Verena Member. The lithology of the Verena Member is the usual biopelmicrite (TS Gy 7171), biopelsparite (TS Gy 7172) and pelsparite (TS Gy 7175). Dedolomitized calcite rhombs occur in beds 1 and 4. The upper boundary of the Verena Member is a smooth, conspicuous parting with an undulating relief of about $20 \mathrm{~cm}$.

The Reuchenette Formation begins with relatively thin-bedded calcilutite (micrite, TS Gy 7176). Bed 13 includes grey to almost black, rounded lithoclasts with a diameter of up to $25 \mathrm{~mm}$. A stromatolite with unusually large birdseye pores forms bed 22. The uppermost bed of the section, no. 23 , is again a calcilutite (micrite) $0.8 \mathrm{~m}$ above the base of the bed there are abundant Cladocoropsis (TS Gy 7181, fig. 18). The same bed with very abundant Cladocoropsis reappears on Mt. Chamben $3 \mathrm{~km}$ southwest of Herbetswil $\mathrm{SO}$ ca. $50 \mathrm{~m}$ castnortheast of point 1251.1, about $8 \mathrm{~m}$ north of the footpath. This is locality RG 432 with PS Gy 4999.

\subsubsection{Section RG 433 Oberdorf $S O$, gorge and quarn north of Waberhilisli (pl.4l)}

The continuous part of the section begins about $40 \mathrm{~m}$ south of the northern end of the gorge on the right (western) side of the creek, at the southern margin of a slope covered with talus. Pelsparite with dedolomite rhombs forms bed 2. Beds 1 to 3 are assigned to the uppermost Günsberg Formation.

Bed 4 forms the bulk of the Steinebach Member. $9 \mathrm{~m}$ above the base this is a fine-grained pelsparite with a high content of arenitic echinoderm bioclasts.

The Laufen Member begins with the thin bed 6 that weathers with a knobby surface. Bed 7 is a bioruditic floatstone that contains oncoids the size of a few millimeters and rhombs of dedolomitc. Corals are only represented as ruditic bioclasts. $\mathrm{Bi}$ valves are very abundant in the middle part of the Laufen Member (bed 11). The upper boundary of bed 13, a pelsparite, is an even, conspicuous parting. This parting is interpreted to be the sequence boundary O8 (GyGl el al. 1998) and the upper boundary of the Laufen Member.

The massive lower half of the Verena Member forms the ridge north of the quarry. The upper bedding plane of bed 14 formed a vast surface at the northern margin of the quarry in 1986. The upper half of the Verena Member, bed 15, crops out within the quarry. In the lowermost $3 \mathrm{~m}$ it is an oosparite. The bivalve Diceras and coarse-grained debris of corals were found in the middle part of the bed. The upper part of bed 15 is pure micrite (TS Gy 7191). There is a marked contrast between the thicknesses of the Verena Member north and south of the Weis senstein range: less than $28 \mathrm{~m}$ near Oberdorf and an estimated minimum of $35 \mathrm{~m}$ near Gänsbrunnen. The upper bedding plane of bed no. 15 is hummocky. Above is a $2 \mathrm{~cm}$ thick marly seam that forms a conspicuous parting. This is the boundary with the Reuchenette Formation.

The sedimentation of the Reuchenette Formation began with pure lime mud of a markedly darker colour than the Verena Member below. Bed 16 is micrite with some rhombs of dedolomite (TS Gy 7192). Bed 17 is micrite which was intensively dolomitized and then entirely dedolomitized. The upper boundary of bed 19 is even and bored. This is interpreted to be sequence boundary K1 (GyGi et al. 1998). Above are $5 \mathrm{~mm}$ of marl. Bed 20 is a dedolomitized micrite with up to $10 \%$ of oncoids with a maximum diameter of $1 \mathrm{~cm}$ and many Cladocoropsis (PS Gy 5014). Clypeina and other calcareous algae occur in the thick bed 32 . The very resistant beds 27 to 32 form the crest of Mt. Geissflue west of the quarry. There is a mass occurrence of Cladocoropsis in the middle of bed 35 (TS Gy 7201, PS Gy 5019). Above bed 43 there is a layer of soft marl with a thiekness of $3 \mathrm{~cm}$. This conspicuous parting is sequenoc boundary $\mathrm{K} 3$ (GYGl ct al. 1998).

The equivalent of the Solothurn Turtle Limestone is represented by the beds 46 to 49 . The mud matrix of the pelmicritic beds 46 and 47 is dolomicrite.

The thin-bedded micrite of beds 52 to 54 is what BuxtorF (1907, p. 58) called Frogyra virgula Beds. The characteristic ostreid that is now called Nanogyra striata (SMTH, 1815) (see ENaY \& Boullier 1981, p. 742) could not be found. Buxtorf assigned these micrites and the remainder of Jurassic limestone above to the Portlandian. AllenBach (1994, p. 118) thought that the thin-bedded micrite in the upper Chuchigraben to the northwest of Rüttenen SO belonged to the Twannbach Formation that is of Tithonian age. The ammonite Aulacostephanus (Aulacostephanoceras) autissiodorensis (COTTEAU) no. 10842 in the Museum of Natural History Solothurn (see Gra 1995. fig. 24) proves however that the "Virgula Beds" near Solothurn are of late Kimmeridgian age. There is a thickness of about $15 \mathrm{~m}$ of well-bedded limestones above bed 59. These could not be measured in detail, because the southern quarry wall is too steep.

\subsubsection{Section RG 434 Lommiswil SO/Oberdorf SO, Steingrueben quarries ( $p l .42$ )}

The lower part of the section was measured in the western quarry near Lommiswil, and the upper part in the adjacent eastern quarry that is in the township of Oberdorf. The base of the thick, massive bed 1 of the Reuchenette Formation is not exposed. $2 \mathrm{~m}$ above the base of the quarry the rock is a yellowishwhite biomicrite with Clypeina and Cladocoropsis as well as some dedolomitized rhombs of calcite. $5.7 \mathrm{~m}$ above the base is fine-grained pelsparite. The upper bedding plane of bed 5 is covered with a limonitic crust with about $1 \mathrm{~cm}$ of soft marl above. Some of the grains in the upper part of bed 6 and in the stromatolite at the base of bed 7 are blackened.

The numerous mostly horizontal branchlets of Cladocoropsis at the upper boundary of bed 12 weather out. This bedding plane is hummocky and covered with a limonitic crust. The crust forms a major surface in the eastern quarry. Beds 17 to 19 were quarried here as building stone at the time of measuring the section. The upper surface of bed 17 is covered with limonite. The uppermost decimeter of the sediment is thoroughly bioturbated. At the surface are few circular, very distinct imprints of sauropods with a diameter of 0.5 to $0.7 \mathrm{~m}$. Around the margin of the imprints are rings of sausage-like mud bulges with a diameter of 6 to $8 \mathrm{~cm}$. This sauropod track was removed some time after it was observed on July 24,1986 . Beds 16 and 17 we re quarried away exposing further tracks on the upper surface of bed no. 15. This bedding plane is now by far the vastest in the quarry. The tracks on 
the bedding plane of no. 15 were discovered by MEYER in February 1987 and published by him in 1990 (p. 391). Traces of cloudy glauconite impregnations have been found in the uppermost part of bed 18. The glauconite is best visible with a hand lens. Under the microscope it takes a magnification of at least 300 to see it well. Bed 18 might be the equivalent of the glauconitic marker bed at the base of the Eudoxus Zone in southern Germany at the boundary between the White Jurassic $\delta 3$ and $\delta 4$.

Beds 23 to 29 are thin-bedded ( 0.05 to $0.25 \mathrm{~m})$ micrite with burrows. This is the "Portlandian" of Buxtorr (1907). The "Exogyra virgula", now Nanogyra striata (SMITH), that LANG (1863. p. 22) mentioned from this locality could not be found. The mud pebbles in bed 31 are argillaceous and weather out as centimeter-sized pockets. Bed 42 is a wavy laminated stromatolite. The peloidal wackestone of no 46 is the uppermost bed that is visible along the road south of the quarry.

\subsubsection{Region of Balsthal}

\subsubsection{Section RG 440 Rumisberg BE, Rittelhorn, gully east of summit ( $p l .43$ )}

The section begins at the lower end of a steep gully about $100 \mathrm{~m}$ to the east of the summit of Mt. Rüttelhorn. It is the middle one of three gullies that best exposes the Balsthal and the lower Reuchenette Formations. It is not clear in which member of the Balsthal Formation the section begins. To judge from the thickness of the exposed part of the formation, one would expect that the Steinebach Member is represented in the lowermost part of the section. But this is uncertain, because the Steinebach Member can be easily recognized in the section RG 436 near Aedermannsdorf in the Horngraben gorge below Eggli cliff which is only about $350 \mathrm{~m}$ to the northeast. The upper boundary of the Steinebach Member is there a characteristic palcosol with micritic nodules covered with acicular calcite "raggioni" of MUTT 1994, fig. 8B). In the section RG 436 the upper Balsthal Formation is dissected by a major fault and therefore the total thickness of the formation cannot be measured exactly.

The base of bed 1 of the section RG 440 is covered by talus. The bed contains oncoids with a diameter of up to $2 \mathrm{~cm}$, small gastropods, echinoderm bioclasts and coral clasts the size of several centimeters in a dedolomitized lime mud matrix. The large oncoids and the corals are an indication that this bed is at the base of the Holzflue Member. The dedolomitized calcite in the matrix is ferroan similar to bed 2 . Oncoids have been found as high up as bed 7 indicating that the beds 1 to 7 are lateral equivalents of the Laufen Member. Bed 8 is a massive oolite that has been almost totally recrystallized by dolomitization and subsequent dedolomitization $5.8 \mathrm{~m}$ above the base. This is the facies of the Verena Member with its hidden oolitic texture. The ooids can often only be seen on weathered surfaces. The oolitic texture with partly recrystallized rock (dedolomitc. pseudomorphs of calcite after sulfate) continues to the upper boundary of bed 12 . Bed 13 is a micrite with recrystallized ooids (sparite and micrite) at the base and rhombs of dedolomitized calcite in the middle. Near the upper boundary of the bed there are nodules of limonite with a diameter of up to $1 \mathrm{~cm}$. The typieal facies of the Verena Member reappears in bed 14 that was originally an oolitic grainstone (TS Gy 7330) with most ooids now being micritized. In the middle part the rock has been dolomitized and then dedolomitized. The lower boundary of the bed forms an overhang in the cliff south of the summit of Mt. Ruttelhorn. In the upper part of the bed there are small limonite nodules within the ooids and in between them. The nodules may be as large as $12 \mathrm{~mm}$ in the uppermost $10 \mathrm{~cm}$ of the bed. The upper boundary is an even, conspicuous parting.

The lowermost few meters of the Reuchenette Formation are well-bedded micrite. There are tiny bivalves with a length of about $0.5 \mathrm{~mm}$, probably of the genus Bositra, in bed 15 . A stromatolite with a thickness of $0.6 \mathrm{~m}$ forms bed 20 which weathers back. The wavy layers are between 5 and $30 \mathrm{~mm}$ thick. There are thin dewatering cracks being parallel and perpendicular to the layers as well as birdseyes. The upper boundary of the bed has a relief of up to $15 \mathrm{~cm}$. The layers are intersected by this erosion surface at the top of the stromatolite that is interpreted to be sequence boundary K1 (Grat et al. 1998). Bed 30 is a pelmicrite with foraminifera. The lower part of bed 33 is oncolitic, whereas the upper part is a saccharoidal, microsparitic dedolomite. Strongly dolomitized and entirely dedolomitized pelmicrite occurs in bed 34 (TS Gy 7335). The section ends with the massive, bioclastic-oolitic bed 37 .

\subsubsection{Section RG 438 Balsthat SO, road through Steinebach gorge ( $\mathrm{pl}$.44)}

The section begins at the northern margin of a small quarry above the road at the northern entrance to the Steinebach gorge north of the old church of Balsthal. The base of bed 1 is covered by talus. The bed is a slightly marly, laminated biopelmicrite with about $10 \%$ of fine-grained, angular detrital quartz. Glauconite, of the same grain size as the quartz, forms less than $1 \%$ of the rock, but it is not rare. This led GyG (1969, pl. 18, section 9) to interpret the sandy succession at the base of the Steinebach Member as a time equivalent of the Crenularis Member. However, the mineralostratigraphic analysis of the sediments (GyG \& Persoz, 1986) revealed that this was an error and that the Steinebach Member was the time equivalent of the Geissberg Member. The saccharoidal bed 7 is a partly dedolomitized dolomite (microsparite). Part of the dedolomitized calcite is ferroan (TS Gy 7284). The slightly marly beds 1 to 11 are transitional between the Effingen Mcmber below and the Steinebach Member above. The predominantly calcarcous facies and the high peloid and ooid content indicate that beds 1 to 11 are rather to compare with the grainstones of the Steinebach Member than with the argillaceous mudstones of the Effingen Member below.

The Steinebach Member proper is an oosparite with some cross-bedding and a total thickness of $13 \mathrm{~m}$. Small oncoids with a diameter of up to $6 \mathrm{~mm}$ appear in bed 14 . In bed 23 the oncoid content may be up to $30 \%$ and the diameter of the oncoids up to $20 \mathrm{~mm}$ (PS Gy 5112). Oncoids up to $20 \mathrm{~mm}$ in size form as much as $20 \%$ of the rock in the upper part of bed 24 . This bed grades upward into a porous, yellowish-white oosparite with thin cross-bedding. The ooids do not break under the hammer. and the rock weathers back in a hollow. This unit has already been noted by GerTH (DELHAEs \& GERTH 1912,p. 18) and forms a local marker bed between Mt. Holzflue north of Balsthal and 
the cliff of Chluser Roggen (section RG 450, bed 2). The upper boundary of the bed is transitional.

The first bed of the Holzflue Member (no. 26) is in its upper half a saccharoidal oncolite that has been strongly dolomitized and then almost entirely dedolomitized. The diameter of the oncoids is as much as $12 \mathrm{~mm}$. Fine-grained detrital quartz forms about $1 \%$ of the rock. Oncoids with abundant Bacinella up to $10 \mathrm{~mm}$ in size form about $20 \%$ of bed 27 which has been partly dolomitized and then mostly dedolomitized (PS Gy 5116). There is also some detrital quartz in TS Gy 7293. Some dolomitization and partial dedolomitization has occurred in the oncolitic bed 29. Above bed 29 there are no more oncoids except in bed 37 . Bed 32 is primarily an oosparite which has been strongly dolomitized and then completely dedolomitized. The dedolomitized calcite in the interior of ooids is partially ferroan. The dedolomitized oosparite facies continues upward to bed 41 . There are pseudomorphs of calcite after sulfate in bed 40. Above bed 42 the sediment beeomes more and more muddy. TS Gy 7301 in the lowermost part of bed 44 is primarily an oomicrite. The saccharoidal matrix has a finely-grained pseudopelsparitic texture. The ooids are replaced by calcitic sparite. This characteristic unit has been figured by Тsсним (1983. fig. 21). The major part of bed 44 is micrite. Above is a hollow filled with talus that corresponds to a concealed thickness of $6.9 \mathrm{~m}$. The succession continues with mostly oosparite to the upper boundary of bed 49 which is an indistinct parting. This is now assumed to be the upper boundary of the Balsthal Formation (but for a different view see GyG1 1969, pl. 18, section 9).

As GyGl (1995, p. 15) remarked, the boundary between the Balsthal and the Reuchenette Formations cannot be defined satisfactorily near Balsthal. An ammonite that B. Martin and P. Tschumi found in situ in 1980 at Innere Chlus near Balsthal gives a biostratigraphic point of reference (see MARTIN 1984. section 18). The specimen was recently described and figured by GYGI (1995, p. 42 and fig, 19). F. Atrops (Lyon) has identified it as Lithacosphinctes evolutus (QUENSTEDT) and stated that it was from the lowermost Platynota Zone. The ammonite was collected about $2.5 \mathrm{~m}$ below a palacosol in the lowermost Reuchenette Formation that forms a local marker bed. This marker bed occurs in section RG 438, bed 52 (pl.44) in the Steinebach gorge, in section RG 439 , bed 9 at Innere Chlus (unpublished) and in section RG 450 , bed 7 at the cliff of Chluser Roggen (unpublished). The palaeosol is probably time-equivalent with the stromatolite in section RG 440 , bed 20 at Mt. Rüttelhorn (pl. 43). Another local marker bed is the mostly micritic bed 44 in section RG 438, Steinebach gorge ( $\mathrm{pl}$. 44). This micritic bed is also present in section RG 450 at Chluser Roggen (bed 4) and in section RG 440 at Mt. Rüttelhorn (bed 13). At Mt. Ruttelhorn the boundary between the Balsthal and the Reuchenette Formations can be drawn with confidence between the oosparitic bed 14 and the micritic bed 15 (pl. 43). $3.5 \mathrm{~m}$ below the stromatolite. In the Steinebach gorge, the base of the formation as proposed above is $1.9 \mathrm{~m}$ below the palacosol and is possibly coeval with the boundary at Mt. Ruttelhorn. But it must be noted that the boundary between the oosparite of bed 49 and the micrite of bed 50 in section RG 438 of the Steinebach gorge cannot be correlated with the sections 439 and 450 near Balsthal. Moreover, the formation boundary as defined above may be one or two meters too high. The Lithacosphinctes $\mathbf{J} 30530$ from Innere Chlus that is from the lowermost Platynota Zone, has been found $2.5 \mathrm{~m}$ below the palacosol, and the distinct lower boundary of the Reuchenette Formation at Mt. Ruttelhorn is $3.5 \mathrm{~m}$ below the stromatolite (section RG 440, bed 20).

The palaeosol in the Steinebach section RG 438 (bed 52) is exposed in the middle of a tunnel. The matrix is a pale-green, soft marl with decimeter-size, saecharoidal calcareous nodules. The upper boundary of bed 55 is a wavy, distinct parting that might be sequence boundary $\mathrm{K} 2$. Clasts of hermatypic corals with a diameter of up to several centimeters appear in bed 58 . They are in a matrix of oolitic grainstone. Bored coral colonies occur in a matrix of bioarenitic wackestone in bed 59. Corals form small bioherms at about this level below Alt Falkenstein castle at Innere Chlus not far to the south. $0.65 \mathrm{~m}$ above the base of bed 63 there is a small amount of glauconite which has a maximum grain size of 70 microns. In thin section Gy 7311 the glauconite is only clearly visible under high magnification. Massive coral colonies form a densely colonized biostrome $3.5 \mathrm{~m}$ above the base of bed 67 . The section ends with bed 71 that is a bioarenitic wackestone near the base and an almost pure lime mudstone above.

\subsection{Formations and members}

The formations and members of the Oxfordian in Canton Aargau and Canton Schaffhausen have been described by Gval (1969) and again by Gygt \& Persoz (1986). Only the formations and members of northwestern Switzerland will be described here.

The synonymy lists are not complete. Old names that are no longer used are only mentioned if they are relevant.

\subsubsection{Herznach Formation (new)}

\section{Synonymy:}

Couches de Clucy RoLLIER (1888, p. 31, 1893a, p. 64)

Fer sous-Oxfordien Launscher $(1948, p .7)$ and by other authors, name adopted from MARCoU $(1848$, p. 84)

Eisenoolithische Schichten des Mittel- und Ober-Callovian STZ̈UBLe (1959,p. 64)

Anceps-Athleta-Schichten Fischer (1965a, p. 11)

A thin, but apparently continuous unit of iron oolitic marl and limestone occurs in northwestern Switzerland between the underlying Dalle nacrée Formation and its lateral equivalents and the overlying Renggeri Member of the Bärschwil Formation. SräUBLE (1959, p. 64) named these strata rather neutrally "Eisenoolithische Schichten des Mittel- und Ober-Callovian". Other authors have named the beds differently (see above). The only previously proposed name that is acceptable after the modern rules of stratigraphic nomenclature (AMERICAN Commission on Stratigraphic Nomenclature, 1961) is the "Couches de Clucy" of Rothier (1888, p. 31). But it is impossible to use this name, because ROLUER neither stated where the 
type locality was nor gave a definition of his new member. It appears to be advisable to give a new name to the widespread unit in the sense of STÄUBLE (1959) that has been mined for iron at many localities in the Jura in the past and has even given rise to local names like "Erzberg" east of Schelten Pass. The bestknown iron mine in this unit is the one near Herznach AG that has been worked mainly during the second world war. It is therefore proposed that the unit is named Herznach Formation.

The Herznach Formation includes the whole of the iron oolitic succession that was exposed in the disused Herznach iron mine. The small thickness of the unit (ca. $1 \mathrm{~m}$ in northwestern Switzerland, $3.4 \mathrm{~m}$ near Herznach) is rather at the scale of a member. Nevertheless, it is recommended to classify the unit as a formation because of its great temporal and regional extent. The type section is the one figured by JEANNET (1951, fig. 2) in the iron mine of Herznach. The mine has not been accessible since 1976. This disadvantage is outweighed by the detailed lithologic and palacontologic work that has been published by JeANNEt (1951) (see also Grgi \& Marchand, 1982). The lower boundary of the new formation in the type section is at the top of bed $\mathrm{A} 4$ and the upper boundary at the top of bed F 3 in fig. 2 by JEANNET (1951). In northwestern Switzerland. in section RG 280 in the clay pit of Ampthil near Liesberg BL as figured by GYol (1990a, fig. 2), the formation begins at the base of bed 4 and continues to the top of bed 6 . The eastern boundary of the formation is beyond the border of Canton Schaffhausen with Germany. The western boundary is beyond the border of northwestern Switzerland with France.

Ammonites are the dominant element of the macrofauna in this unit, an these are taken as evidence that the formation has been laid down in relatively deep water (according to GrGl, 1986, fig. 6).

\subsubsection{Bärschwil Formation}

Synonymy:

Marnes oxfordiennes proprement dites MARcou (1848,p. 84)

Lower Rauracien of older Swiss authors pro parte

Oxfordien of older authors (see for instance LAUBSCHER 1948. p.8)

Barschwil Formation GYGI \& MARCHAND (1993, p, 998)

The Barschwil Formation is a succession of clayey marl and marl with bands of calcareous nodules and limestone beds in its upper part. It includes the Renggeri Member at the base, the Sornetan Member in the middle and the Liesberg Member at the top. It occurs in a vast area in eastern France (CoNIIN 1976 , fig. 3) and in northwestern Switzerland (GYot 1990c, figs. 2 and 3). The only locality where the formation actually is completely exposed is section RG 280 in the clay pit of Ampthil near Liesberg BL. However, the formation cannot be named after Liesberg, because this name has already been given to its uppermost member. Another good outcrop is the section RG 399 in the upper part of the landslide west of Vögeli farm near Bärschwil SO although the Renggeri Member is covered by mud and debris at this locality. This natural outcrop will probably remain relatively fresh for a long time and is proposed here to be designated as the type section of the Bärschwil Formation (pl. 34)
The lower boundary of the formation can actually best be studied in the section RG 280 near Liesberg (pl.30). The base is taken at the contact between beds 6 and 7 , that is at the point where the iron ooid content of bed 6 has decreased upwards to zero (see Gygr 1990a, fig. 2). The age of the lower boundary is the early Scarburgense Subchron (fig. 40), because Cardioceras (Scarburgiceras) cf. scarburgense J 30717 has been found in the upper part of the iron oolitic bed 20 in section RG 307 in the quarry of La Charuque near Péry BE (GYG 1990a, p. 183). This is the uppermost bed of the Herznach Formation at that locality. The term chron (and the term subchron derived from it) is used here according to HedBerg (1976, p.68). The upper boundary of the Barschwil Formation is transitional in the type section RG 399 (pl.34). It is drawn at the base of the first thick limestone bed of the St-Ursanne Formation (no, 118) which grades laterally into marl. Generally the upper boundary can be drawn at the base of the cliff formed by the limestone of the St-Ursanne Formation above. Where the Bärschwil Formation intersects the surface in the folded Jura it is characterized by extensive natural depressions in the landscape (combes oxfordiennes of GREPPIN 1870, p. 61).

\subsubsection{Renggeri Member}

Synonymy:

Marnes oxfordiennes Thurmann (1830, p. 26)

Couches a Ammonites renggeri CHOFAT (1878, p. 115)

Renggeriton FISCHER (1965b, fig. 5)

Renggeri Member GyGl \& Persoz (1986, p. 394)

The Renggeri Member is named after the ammonite Creniceras renggeri (OPPEL) that occurs in the lower part of the member (GYGi 1990a, fig. 3, pl.4, figs, 19, 20,23,24). The member is a homogenous, blue-grey clayey marl without calcareous or sandy intercalations. It lies between the iron colite of the Herznach Formation below and the lowermost nodule band or limestone bed of the Sornetan Member above. The Renggeri Member cannot be subdivided lithologically. The only subdivision that has been made so far is biostratigraphic (GrGi 1990a fig. 3). The age of the member ranges from the beginning of the Scarburgense Subchron to the end of the Costicardia Subchron. There is only one section where the member is actually completely $\mathrm{ex}$. posed at its normal thickness; this is the clay pit of Ampthil (RC 280, pl.30) near Liesberg BL. Bed 7 of the section RG 280 is therefore designated as the type section of the Renggeri Mem. ber. The member thins and wedges out completely towards the south and east (GrGr 1990a, fig. 4, 1990b, fig. 2 and this paper fig. 39). The facies of the member is very uniform throughout it range. Slopes on top of the Renggeri Member give rise to land slides. The macrofauna of the member is dominated by am monites. There is some benthos, but it is rare. This and the bio turbation of the sediment (sec fig. 7) are evidence that th Renggeri Member was not deposited in anoxic, but rather i dysaerobic conditions. The ammonite fossils are almost invari ably small and preserved as iron sulfide. 


\subsubsection{Sornetan Member (new)}

Synonymy:

Terrain à chailles THURMANn $(1830, \mathrm{p} .23)$

Argovien Marcou (1848, p, 88)

Pholadomyen DE Tribolet in Etallon (1862.p. 245)

Terrain à chailles marno-calcaire GrepPIN $(1867$, p. 64)

Terrain à chailles LiNICER (1925, p. 2)

Terrain à chailles Fischer (1965b, fig.5)

This member is a succession of bluc-grcy marl with a maximum thickness of more than $50 \mathrm{~m}$ (GYGr 1990b, fig. 4). Intercalated in the marl are bands of tough, ellipsoidal, carbonate concretions ("chailles") at varying lateral distances (fig. 31). There are also some continuous beds of more or less marly limestonc. Both the concretions and the continuous limestone beds are microsparitic. The concretions of a distinct horizon in the distal part of the member contain abundant macrofossils as recorded by GYGI \& MARChAND (1993, p.999), Liniger (1925, p. 2) thought he could subdivide the member into a lower part with "Rhynchonella thurmanni VoLtz", now: Thurmannella obirita (Defrance), sce Botulter (1993), and an upper part with Pholadomya exaltata AGAssiz. This is impracticable, because Thurmannella oburita occurs also in the upper part of the member. The member has about the same geographic extent as the Renggeri Member.

The name Terrain à chailles by Thurmann (1830) is misleading, because he cited Thirria (1830) to be the author. The pertinent paragraph by ThIRRIa (1830, p. 19) is about an "argile a madréporaires avec chailles", a clay with corals and cherı nodules. Throria stated that this clay was below the "calcaire compacte avec Nerinea". If this were the case, the "calcaire avec

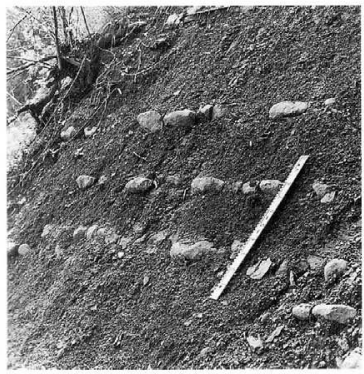

Fig 31: Marl of the middle Sometan Member with ellipsoidal carbon. ate concretions Section RG 399. beds 85-91, landslide west of Yögel farm. Barschwil SO. Scale is $1 \mathrm{~m}$. See pl. 34.
Nerinea" might be the equivalent of the St-Ursanne Formation and the "argile à madreporaires avec chailles" the equivalent of the Liesberg Member. But on p.21, THIRrIA claims that the "argile à madréporaires avec chailles" was above the "calcaire à Nerinea", and on p. 25 that the "argile avec chailles" was immediately below the "calcaire à Astarie". The "argile à madreporaires avec chailles" by THIRRL might therefore be the equivalent of the Humeralis marl of the Swiss authors as for instance of ZiegLer (1956, fig. 14) or of GYGl \& PERSOZ (1986, pl. 1) and would then be much younger that the "Terrain a chailles" by Thurmann. To judge from the section described by Chorfat (1878, p. 121) it is probable that the "argile à madréporaires avec chailles" of THIRRIA is the equivalent of the Liesberg Member of Rollier (1888).

THIRRIA (1830, p. 21) wrote that his "chailles" were "boules de calcaire siliceux", nodules of siliceous limestone. The microsparitic limestone concretions of the Terrain à chailles of modern Swiss authors are however not siliceous. Neither are the limestone concretions of the Liesberg Member, but these contain partly silicified fossils. Modern French authors use the term "chailles" for chert nodules. Tough carbonate nodules like those found in the unit that is described and proposed as the Sornetan Member are referred to as "sphérites" by EnAY (1966, p. 210). Thurvans (1830,p. 23) himself called the nodules of his Terrain à chailles "sphérites".

A further source of confusion is the fact that GrEPrin (1867. p. 64) introduced the name "Terrain à chailles siliceux" for what Rollier (1888, p. 71) later called "Couches de Liesberg" and even wrote of a "terrain à chailles oolithique" (Grepriv 1870. p. 79) that he did not define. Fortunately, both names are not used any more by modern authors and may be rated to be forgotten. Modern Swiss authors are unanimous about what is to be understood by "Terrain à chailles", as for instance GYGI \& PERsoz (1986, p. 395). Nevertheless, it is proposed here to abandon this name because of its ambiguity. In the French speaking part of Switzerland, it should at least be replaced by "Terrain à sphérites". A better solution is probably to replace it by a formal new name based on it's geographical occurrence as has been proposed above.

There is only one section where the Sornetan Member was ever exposed cleanly and completely. This is RG 306 in the clay pit of Hinter Chestel near Liesberg BL (pl.31). Another good outerop is section RG 399 in the landslide west of Vögeli farm near Barschwil SO (pl.34), but there, the boundary with the Renggeri Member is covered by talus. More exposures occur below the cliff of the St-Ursanne Formation at Sous la Peute Roche west of Vellerat (section RG 373, pl.24). However. Vellerat is a formation name that has been introduced by $\mathrm{BoL}$ LIGER \& BURRI (1970,p.71). Another fairly good section is the lower part of RG 314 in the Pichoux gorge near Sornetan BE. Bed 1 of this section is the fossil bed of the middle Sornetan Member (see Grai \& Marchand 1993, p. 999). It is therefore proposed here to call beds 1 to 15 in section RG 314 Sornetan Member (pl. 21) and to designate section RG 306 near Liesberg (beds 2 to 98 ) as the reference section (pl.31). The lower boundary of the member is taken where the first band of lime stone concretions or the first limestone bed appears above the Renggeri Member. The upper boundary is fixed where her- 
matypic corals appear in great numbers and the limestone concretions begin to have an irregular, non-ellipsoidal shape.

The macrofaunal assemblage of the Sornetan Member comprises brachiopods, bivalves and ammonites. Ammonites dominate in the lower half of the member and brachiopods and bivalves in the upper half. This is interpreted as an overall shallowing of the water during the sedimentation of the member. The age of the member ranges from the beginning of the Cordatum Subchron to the early Antecedens Subchron.

\subsubsection{Liesberg Member}

Synonymy:

?Argile à madréporaires avec chailles THIRRıA (1830, p. 19)

Glypticien ETALLON (1862, p.63)

Tcrrain à chailles siliceux GREPPIN (1867,p. 64)

Couches de Liesberg RoLler (1888, p. 71)

Liesberg-Schichten ZIEGLER (1962, p. 29)

Liesberg-Schichten Bot.tiger \& Burki (1970, p. 69)

Liesberg Member GyGt \& PERsoz (1986, p. 395)

The Liesberg Member is typically a grey marl with bands of limestone concretions or beds of marly limestone. The nodules have an irregular shape unlike the ellipsoidal concretions in the Sornetan Member. Up to $30 \%$ of the rock volume may be hermatypic corals (fig. 32) that are dish-shaped in the lower part of the member and mostly ellipsoidal in the upper part. The corals and the other, abundant macrofossils may be partly silicified. The carbonate content of the rock increases upward, so that the upper boundary of the member can be transitional.

The most proximal occurrence of the member has been recorded near Bure $J U$ (section RG 456, beds 13 to 15 , unpub-

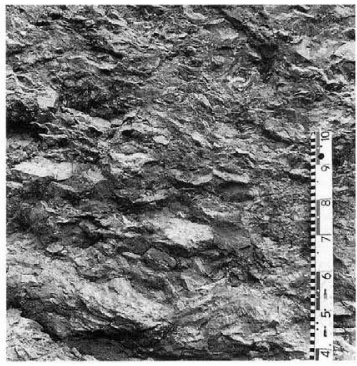

Fig. 32: Marl of the upper Lieshere Member with abundant dish-like coral colonies. Section RG 306 , clay pit of Hinter Chestel, bed 105, Liesherg BI. Scale is decimeters See pl. 31 . lished). The greatest thickness of $25 \mathrm{~m}$ was measured in section RG 306 near Liesberg BL (pl.31). The position of the distal boundary of the member is not exactly known. The unit probably wedges out below the marginal coral bioherms of the St-Ursanne Formation (Gygr \& PERsoz 1986, pl.1).

A complete, easily accessible section of the member is RG 306 in the clay pit of Hinter Chestel near Liesberg BL. It is therefore proposed to designate the beds 99 through 106 of RG 306 as the type section of the Liesberg Member (pl.31).

The lower boundary is drawn where hermatypic corals appear suddenly in great numbers above the Sornetan Member. The upper boundary is where the carbonate content of the rock becomes sufficient to form an uninterrupted clift.

By far the most abundant fossils in the Liesberg Member are hermatypic corals. There are also cchinoids like Paracidaris florigemma (PHiLLIPs), thus the old name Florigemma Beds. large crinoids like Liliocrinus munsterianus (D'ORBIGNY) that have often the original purple colour in their rootstocks (fringelite, see BLUMER 1951), bivalves (mainly pectinids) and brachiopods.

Ammonites from the Antecedens Subchchron of the Transversarium Chron have been found below and above the Liesberg Member (Gyol 1995, fig. 2,14 and 25). Thus, the Liesberg Member represents only a part of the Antecedens Subzone.

\subsubsection{St-Ursanne Formation}

\section{Synonymy:}

Oolite corallienne and calcaire à nérinées THurmanN (1830)

Terrain corallien ou rauracien Gressiy (1864,p. 96)

Mittleres und oberes Rauracien KocH $(1923$, p. 2)

St-Ursanne-Formation Bol.uger \& BLRRI (1970.p. 69)

St-Ursanne-Formation HECKENDORN (1974, p. 11)

St-Ursanne Formation GYGI \& Persoz (1986, p. 395)

The St-Ursanne Formation is a succession of shallow-marine limestones that are underlain by the Bärschwil Formation and overlain by the Vellerat Formation. The St-Ursanne Formation can be subdivided into the Grellingen, Delémont, Buix and Tiergarten Members (see below). The geographic range of the formation is northwestern Switzerland, where the shallowing-upward Bärschwil Formation below has a thickness of $100 \mathrm{~m}$ or more (GvGl 1990c, figs 2,4 and 5). The only section where the StUrsanne Formation is completely exposed is at the cliff of Peute Roche near Vellerat JU (sections RG 389 and 451, fig. 20, pl. 24). It is proposed here to designate the cliff of Peute Roche below P. $957.9,900 \mathrm{~m}$ west-southwest of Vellerat JU as the reference section of the St-Ursanne Formation. In section RG 389 the base of the formation is marked by the base of bed 6. The top of the formation is defined in section RG 451 as the top of bed 4 . The lower part of the Formation (Grellingen Member) and the upper part (Tiergarten Member) are easily accessible along the forest road to the Foret de la Cendre $700 \mathrm{~m}$ to the north of Vellerat JU (section RG 296, unpublished). The best-known section of the St-Ursanne Formation is along the road near the railway station of St-Ursanne and in the quarry of the former lime works close by (PÜMPIN 1965, pl.1. section 2, section RG 336 in 
Fig. 33: The St-Ursanne Formation near SI-Ursanne JU. On the left: eliff of the older Delemont Member below. coral reef of the younger Buix Member above. The tunnel entrances of the lime works are in the middle Buix Member. The section ends with the wellbedded Vorbourg Member of the lower Vellerat Formation.

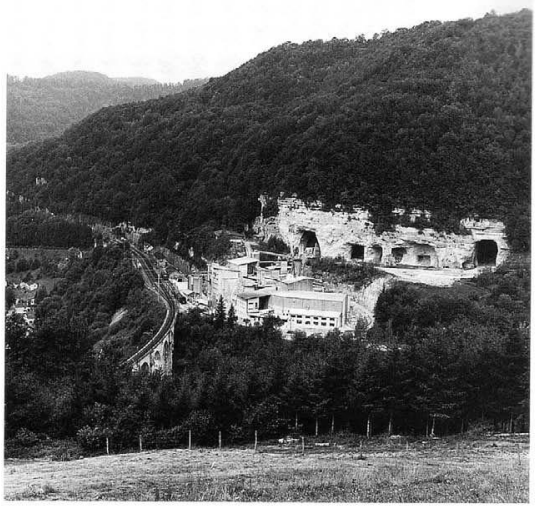

Gra 1982. fig. 4 and this paper, fig. 33). BolLLIGER \& Burri (1970, p. 69) have designated this as the type section.

The lower boundary of the St-Ursanne Formation is transitional (see above). The thickness of the formation varies greatly over short distances:35 m near Kleinlützel SO (section RG 397) and $95 \mathrm{~m}$ near Liesherg (section RG 306, pl.31). The upper boundary is where the massive, often porous lime mudstone of the Buix Member or the oolite of the Tiergarten Member becomes a well-bedded lime mudstone with a low porosity (Vorbourg Member). This boundary can again be a transition. The distal edge of the formation is the belt of coral bioherms at the margin of the carbonate platform as it may be seen in the $\mathrm{P}_{1}$ choux gorge near Sornetan BE (section RG 315, pl. 21). The Delémont and the Grellingen Members are erosion-resistant and form cliffs, whereas the Tiergarten and especially the Buix Members weather back. The fossils of the St-Ursanne Formation are predominantely hermatypic corals. The corals form mainly biostromes in the Grellingen Member and bioherms at the platform margin and in the lagoonal Buix Member. Regular echinoids can be abundant adjacent to lagoon reefs. The nerinean gastropods that gave rise to the name "calcairc à nérinées" are uncommon. The age of the St-Ursanne Formation is from the late Antecedens Subchron to the Luciaeformis Subchron (Grot 1995, fig. 2)

\subsubsection{Grellingen Member (new)}

It is proposed here to call the lower part of the St-Ursanne Formation in the proximal and in the distal areas Grellingen Member. The member is chiefly a coral biostrome with a micritic or bioarenitic matrix. Coral bioherms are uncommon; they occur at Sous les Cantons northwest of Buix JU (sce LiNiger 1970, p. 7). below (south of) point 1030 at the southern tip of Forêt de la Cendre west of Vellerat JU and at the foot of the cliff of Montchemin south of Courrendlin JU.The Grellingen Member forms the cliffs in the lower part of the St-Ursanne Formation near Grellingen BL, mainly at Falkenflue, Eigenhollen and Chastelberg west of the Chastelbach. A complete, easily accessible section is RG 296 north of Vellerat along the road to Forêt de la Cendre.

\subsubsection{Delëmont Member (new)}

Synonymy:

Oolite corallienne ThurmanN (1830,p. 17)

Blauenschichten TOBLER (1905, tab.5a)

Blauen-Schichten Косн (1923, p. 2)

pars Caquerelle Pisolite ZIEGLER (1962,p. 18)

The Delémont Member is mainly a carbonate oolite. It makes up the lower half of the St-Ursanne Formation in a narrow belt. Hermatypic corals are fairly common, chiefly in the lower part of the member. Oncoids are abundant and range in size from 
less than $2 \mathrm{~mm}$ to $2 \mathrm{~cm}$. PüMPIN (1965,p. 816) concluded that the oncoids had been formed by cyanobacteria and foraminifera. They are unlike the larger oncoids in the Röschenz. Hauptmumienbank and Laufen Members. The oncoids of the Delémont Member can be concentrated enough to form truc oncolite near St-Ursanne. This is the local facies of the "Caquerelle-Pisolith" of ZIEGLER (1962, p. 18) which is named after the farm La Caquerelle in the township of Asuel JU.

The Delémont Member forms a belt with a width of 4 to $8 \mathrm{~km}$. This belt runs from Ocourt JU on the Doubs river to StUrsanne. Delémont, Liesberg. Dittingen and Blauen BL. The member is completely exposed in section RG 306 , beds no, 107 to 110 (pl.31), in the quarry of Chestel. Liesberg BL. This quarry can be considered as the reference section of the member. The name of the member refers to section RG 366, Vorbourg chapel, beds 1 to 9 (pl.23) near Delémont. The synonym Blauen-Schichten ToBLEx (1905, tab.5a) is forgotten and should not be revived, because there is no good section of the unit near Blauen BL. The best outcrop of the Caquerelle oncolite is in the unpublished section RG 338, Cote du Frène, bed 90 (PS Gy 3899) near Asuel JU (see ZIEGLER, 1962, fig. 1, POMPIN, 1965 , figs 6 and 7). The Caquerelle oncolite of ZIEGLER (1962) in the lower St-Ursanne Formation should not be confused with the Couches de la Caquerelle of Rot Lier (1892, p. 282) in the upper St-Ursanne Formation that are mentioned by WAIBEL. in the LexiQue StratigraphiQue International (1960).

The delineation of the Delemont Member is neither vertically nor laterally clear-cut. The lower boundary with the Liesberg Member is transitional. Oncoids are locally also present in the Liesberg Member. The Delémont Member interfingers laterally with the Grellingen Member.

\subsubsection{Tiergarten Member}

Synonymy:

Tiergarten-Oolith Bolliger \& BURRI (1970, p. 71)

Bolliger \& Burri (1970) introduced the term Tiergarten oolite for all the oolites in the St-Ursanne Formation, consequently also for what is called here Delemont Member. Their term is therefore too loose. Nevertheless, it is proposed here to retain the name and to give it the following, new definition: The Tiergarten Member includes the oolite of the upper St-Ursanne Formation between the distal Grellingen Member below and the Vorbourg Member or the Günsberg Formation, respectively, above. The Tiergarten Member (named after a poor outcrop in the Tiergarten gorge west of Vermes JU) is the distal time equivalent of the Buix Member (see below).

The Tiergarten Member forms a belt 6 to $9 \mathrm{~km}$ wide between the Buix Member and the string of coral bioherms at the platform margin of the St-Ursanne Formation. Coral patch reefs are quite common in the distal part of the Tiergarten Member. mainly near Grellingen. A particularly good example is to the west of the creek at Eigenhollen, coordinates 612.950/253.600, National Map 1:25000, sheet 1087 Passwang.

The name Tiergarten Member refers to the Tiergarten Gorge of the Gabiaire Creek between Vermes JU and Vicques JU, but the exposure of the member is very incomplete at that location (see section 9 by BoLl.tger \& Burrt 1970, pl. 16). It is therefore proposed to designate bed no. 4 in the section RG 451 at the cliff of Peute Roche near Vellerat (pl. 24) as the type section of the Ticrgarten Member. A good, easily accessible section close by is RG 367 along the road from Vellerat to Courrendlin at Les Esserteux (sec section no. 8 by BoLLIGER \& BURRI 1970,pl.16).

\subsubsection{Buix Member (new)}

Synonymy:

Calcaire à nérinécs Thirria in Thurmann (1830,p. 16)

Calcaire à nérinées Gkeppin (1870, p. 85)

Couches de la Caquerelle RoLLIER (1892, p. 282)

Caquerelleschichten ToвцE (1905, tab. 5a)

Rauracien crayeux LiNiger $(1925$, p. 2)

Caquerelleschichten Warbet (1960, p. 39 and 49) in Lexiove StratigraphiQUe INTERNATIONAL

Kreide von St. Ursanne Zieglek (1962, fig. 1)

Caquerelle-Schichten Hess (1975, tab. 2)

The Buix Member is a massive, yellowish-white to pure white. more or less porous limestone. It can be so friable in some places that it can be pulverized by rubbing a piece of the rock between the fingers. Coral bioherms occur in this unit near Leymen F, Fluh BL, Delémont, St-Ursanne JU and Buix JU. Locally, the limestone was originally slightly dolomitic, but the euhedral dolomite crystals have been dissolved and left empty pores (unpublished section RG 344 , beds 3 and 8 , Courtemaiche JU). In this case, the rock weathers in perpendicular rods as Liniger $(1970, p .7)$ has observed. Chert nodules occur in the upper Buix Member near Courtemaîche (sections RG 343,344). The uppermost part of the member is oolitic near Liesberg (section RG 306, pl.31) and near Blauen BL (KoBY 1892, p. 404).

The Buix Member is a lagoonal sediment that was deposited in the proximal area behind the oolite bar of the Tiergarten Member which rimmed the carbonate platform of the upper StUrsanne Formation. Typical outcrops are found in Canton Jura near St-Ursanne and north of Porrentruy. The best, complete outcrops of the member are in the quarry and the tunnels of the former lime works near the railway station of St-Ursanne. Another good outcrop with a coral bioherm is in the quarry of Les Creppes near Buix JU (section RG 347, unpublished) which is easily accessible. Section RG 336 at St-Ursanne is proposed as the reference section of the member (see POMPIN 1965, pl.1, section 2, beds 8 to 10 and Grat 1982, fig 4).

Caquerelle Member would be a suitable name for the unit although RoLLIER (1892) gave neither a type locality nor a definition of the member. Neither the mapping geologists nor the stratigraphers like Zieglek (1962) and Groi \& Persoz (1986) have adopted the name. It is therefore rated as an obsolete term even though Hess $(1975$, tab. 2) has mentioned it again. Rcnewed use of the name might lead to confusion with the Caquerelle oncolite of ZifGLER (1962, p. 18). It is therefore proposed here to retain the Caquerelle oncolite of ZIEGLER and to give the Caquerelle Member of Roluer (1892) a new name. The best section after which the nember can be named is the quarry of Les Creppes (scction RG 347) near Buix JU. 


\subsubsection{Pichoux Formation}

Synonymy:

Calcaires du Pichoux Greprin (1870, p. 80)

Ubergangskalke and Birmenstorfer-Kalke ZIEGLER (1962.p. 34 and 35)

Pichoux-Kalke Bolliger \& Burri (1970,p. 71)

Öbergangskalke GYGI (1982, figs. 5 and 6)

Pichoux limestone Gyar \& Persoz (1986, p. 398)

Pichoux Formation GYGI (1995, p. 10)

The Pichoux Formation is a succession of biomicritic and micritic, bedded limestones that lie between the older, argillaceous Barrschwil Formation and the younger, marly Wildegg Formation (fig. 34). The Pichoux Formation is at its thickest adjacent to the coeval St-Ursanne Formation. The Pichoux Formation thins out towards the basin and has a minimum thickness where it grades laterally into the Birmenstorf Member of the lower Wildegg Formation (fig, 39). Gressix (1864, p. 103) already noted this facies transition.

Good outcrops of the Pichoux Formation are found in the Pichoux gorge (sections RG 314 and 315, pl.21) near Sornetan BE.in the Combe des Geais (unpublished section RG 410) near Grandval BE (GyGI \& PERsoz, 1986, fig.6), in a ravine near Ver- mes JU (section RG 406, pl.37) and in the Court gorge near Mouticr BE. A good and complete section of the formation is the one on the eastern slope of the Court gorge (fig. 34). ZIEGLER (1962,section 23) has given a schematic drawing of this outcrop which can only be measured using a rope. An exploration well for the Transjurane highway (section RG 452) provided a complete section of the Pichoux Formation in the Court gorge. So it was unnecessary to measure the outcrop depicted in fig 34 on the rope. The thickness of the Pichoux Formation in the well is $60 \mathrm{~m}$, not $41.5 \mathrm{~m}$ as indicated by ZIEGLER (1962). A large part of the formation is accessible close by in a road tunnel at coordinates $592.870 / 233.500$.

The type section of the Pichoux Formation has been designated by Bolliger a Burrt (1970) to be in the Pichoux gorge. This is unfavorable, because the upper St-Ursanne Formation progrades in that section (RG 315, pl.21) over the Pichoux Formation. The Pichoux Formation is thus incomplete at that locality. A complete outcrop of the formation is in section RG 406 in a ravine near Vermes JU (pl.37) on the north slope of Mt. Raimeux. The beds 1 to 6 of section RG 406 are a good reference section of the Pichoux Formation, although the upper boundary of the formation cannot be easily defined. The boundary is drawn where detrital quartz appears in the limestone of the lower Günsberg Formation.
Fig. 34: The Pichoux Formation on the eastern slope of Court gorge near Moutier BE. The Sornetan Member at the base is covered by talus The argillaceous Effingen Member is visible above the clear-cut upper boundary of the Pichoux Formation. Above in the forest are limestones of the lower Gunsbera Formation.

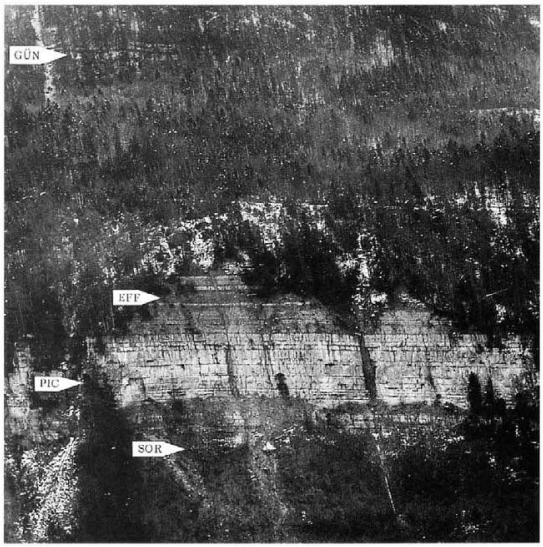




\subsubsection{Vellerat Formation}

Synonymy:

Couches d'Angolat Rollier (1888, p. 60)

Couches de l'Angolat GrePPIN (1893,p.8)

Vellerat-Formation BoLLIGER \& BURRI (1970,p. 71)

Vellerat Formation Gygl \& Persoz (1986, p. 398)

Vellerat Formation GyGı (1995, p. 10)

RoLLier (1888, p. 60) was the first author who recognized that the sediments that form a depression between the underlying St-Ursanne Formation and the overlying Courgenay Formation are a mappable unit and need a name. He proposed "Couches d'Angolat" and referred to a small gorge called "En Goulat" by the inhabitants of Soyhières JU which is the type locality. GrEpPIN (1870.p.92) gave a section of the locality that is $1 \mathrm{~km}$ to the northwest of Soyhières. Neither the mapping geologists of the University of Basel as for instance LiNiger (1925) nor ZIEGLER (1956) used Roluer's term, and it must therefore be considcred to be forgotten.

More than 80 years later. Bolliger \& BURRI (1970,p. 71) renamed these sediments Vellerat Formation without reference to ROLLIER. This would be a useful term if it had been limited to the deposits above the St-Ursanne Formation. But the authors included the more distal Günsbcrg and the Steinebach Members in their new formation which consequently overlaps with the Balsthal Formation of Gygi (1969). GYGi \& Persoz (1986, p. 398) retained the Vellerat Formation in spite of this ambiguity, but restricted it to the sediments above the St-Ursanne Formation (sce Grat 1990b, fig, 5), this is to say the Vorbourg Member, the Natica (now: Röschenz) Member. the Hauptmumienbank Member and the Humeralis Marl (now: Bure Member).

Complete sections of the Vellerat Formation are always temporary. A major problem is where to place the lower boundary of the formation. Grepris $(1870)$ included what is now the Vorbourg Member in the St-Ursanne Formation. Liniger (1925, p. 2) did the same with the argument that the Vorbourg Member forms an escarpment or cliffs together with the St-Ursanne Formation. Gral \& Persoz (1986, pl.1) assigned the Vorbourg Member to the Vellerat Formation, because the Vorbourg Member could be correlated with the lower Effingen Member. The upper boundary of the Vellerat Formation is where cliff-forming limestones appear above the Bure Member. The correlation and the age of the Vellerat Formation are indicated in fig. 40.

\subsubsection{Vorbourg Member}

Synonymy:

non Couches du Vorbourg GrepPIN (1893,p. 16, pl. 8, fig. 2)

Plattige Kalke Launscher (1948, p. 9)

Plattenkalke ZIEGLER (1956, p. 51)

pars Vorbourg-Kalke ZIEGLER (1962, p. 21)

Vorbourg-Kalke LiniGer $(1970$, p. 9$)$

Vorbourg-Kalke BoLLiger \& BURRI (1970, p. 72)

Vorbourg-Kalke HECKENDORN (1974, p. 11)

Vorbourg Member Grgi \& Persoz (1986, p. 399)

Vorbourg-Kalke BITTERL \& Fischer (1988, p. 18)

Vorbourg-Schichten GYGr (1995,p. 10)
The Vorbourg Member as renamed by ZIEGLER (1962) is interpreted here in the restricted sense of LiniGer (1970). It is a succession of thick-bedded, micritic limestones $10-15 \mathrm{~m}$ thick that lies above the Buix Member and partly above the Tiergarten Member of the upper St-Ursanne Formation below. The Vorbourg Member is overlain by the limestones and marls of the Röschenz Member. The type section is RG 366, Vorbourg chapel near Delémont (pl.23).

It can be read from the above synonymy list that the term Couches du Vorbourg by GreppIN (1893) is forgotten. It was proposed for a succession of bedded limestones in the lowermost Reuchenette Formation between the massive limestone of the Verena Member below and the argillaceous Banné Member above. This was ignored by subsequent authors Today only the Vorbourg Member of ZiEgler (1962) is used. Fischer (1965a, p. 17) has remarked that the Vorbourg Member of M. ZIEGLER (1962) overlapped with the lower Roschenz Member. Gral \& Persoz (1986, p. 399) have stated that the Vorbourg Member of ZiEGLER (1962) at the type section also includes the uppermost massive part of the St-Ursanne Formation (bed 12 of section RG 366 in this paper, pl.23). Modern authors agree that the Vorbourg Member should be used in a revised sense (beds 13 to 24 in the type section, pl.23, see also fig. 33).

\subsubsection{Röschenz Member}

Synonymy:

Calcaires a Natices Thurmann \& Etallon (1864, pl.C)

Naticaschichten LiNIGER (1925, p. 2)

Natica-Mergel ZiEGLER (1956, p. 52, fig. 14)

Naticamergel ZiEGLER (1962, p. 26, fig. 1)

Naticaschichten Fischer (1965a, p. 17)

Natica-Schichten BOLLLIGER \& BURRI (1970, p. 72)

Natica Member Groi \& Pensoz (1986, p. 410)

Röschenz-Schichten GYGi (1995, p. 11)

The Rosschenz Member is a very variable succession of limestones and marls that is underlain by the Vorbourg Member and overlain by the Hauptmumienbank Member. The lower boundary of the Röschenz Member is often transitional and is drawn where the first marl intercalation more than $5 \mathrm{~cm}$ thick or marly limestone appears above the Vorbourg Member. The Röschent Member is most argillaceous in the proximal realm (Ajoic. Canton Jura) and grades in the distal direction into the limestone of the Gunsberg Formation. The mean thickness of the Röschenz Member is about $35 \mathrm{~m}$.

The Roschenz Member can be subdivided near St-Ursanne and in the Ajoic into a lower and an upper part. The intervening bed is an erosion-resistant oolite with light ooids in a blue-grey or rusty-brown matrix that has already been noticed by LAUBSCHER (1948, p. 9). This is bed 73 in section RG 359 near Bressaucourt JU (pl. 18) and bed 38 in section RG 454 near Bure JU (pl.16). This might be the equivalent of the Grüne Mumienbank of ZiEGLER (1956) and of the Gerstenhubel Beds in the Effingen Member of the basin (see Gro1 s. Persoz 1986. pl.1).

Complete sections of the Roschenz Member are RG 402 near Röschenz BL (pl. 33) and RG 454 near Bure JU (pl. 16). Section RG 402 was a clean outcrop in the summer of 1983 during a renovation of the road from Röschenz to the Muli. It is 
therefore designated as the type section of the Röschenz Member. The member begins with bed 24 and ends with bed 71 in the type section. Grat (1995, p.11) gave the reason why the unit cannot be called Natica Member any more.

\subsubsection{Hauptmumienbank Member}

Synonymy:

Oolite grossière GressLy (1864,p. 99)

Calcaires blanchâtres à grosses oolithes RoLLIER (1888, p. 61)

Mumienbank RothPLETZ (1933,p. 25)

Hauptmumienbank ZIEGLER (1956, p. 63, figs. 12 and 14)

Hauptmumienbank ZiEGLER (1962, p. 27)

Hauptmumien bank HECKENDORN (1974,p.11)

Hauptmumienbank Member Grar \& Persoz (1986, p. 400)

Hauptmumienbank GYGI (1995, p. 11)

This member is an excellent marker unit between the partially argillaceous Röschenz Member below and the marl of the Bure Member above. It has been described by Zifgler (1956, p. 57) and again in detail by Grgl \& Persoz (1986, p. 400). This limestone succession weathers out in the platform interior as an escarpment (fig. 35) when the beds are flat or forms a prominent ridge where the succession is tectonically tilted (fig. 28).

ZIEGLER (1956, fig. 12) gave a paleogeographic map of the areal extent of the Hauptmumienbank Member. In fact the unit extends further north and northeast than this author indicated (cf. Grat, 1990c, fig. 7). ZiEGLer (1956) has not designated a type section. This ought to be in the Franches Montagnes in Canton Jura where the member grows to its greatest thickness. A good reference section is RG 366 at Vorbourg chapel near Delêmont (beds 67 to 73 in pl. 23).

GyGl \& Persoz (1986, pl.1) proved with clay minerals that the Hauptmumienbank Member grades distally into the Steinebach Member and that this member passes laterally into the Geissberg Member. The age of the Geissberg Member could be fixed with an ammonite to be of the late Hypselum Subchron by Gral (1995, figs. 2 and 23 ).

\subsubsection{Bure Member}

Synonymy:

Humeralis-Schichten (Mergel) ZIEGLER (1950, fig. 14)

pars Humeralisschichten Fischer (1965, p. 19)

pars Humeralis-Schichten BOLLIGER \& BURRI (1970, p. 72)

pars Humeralis-Schichten HeCKENDORN $(1974$, p. 12)

Humeralis marl GYG1 \& PERsoz (1986, p. 401)

Bure-Schichten Grar (1995, p. 11)

ZIEGLER (1956. fig. 14) is the first author who stated unequivocally what he meant by Humeralis-Schichten: first the marl above the Hauptmumienbank Member (now Bure Member) and, second, the limestones between the Bure Member below and the Verena Member above (now La May Member, see below). The lower, argillaceous part of ZIEGLER's Humeralis Beds are therefore part of the upper Vellerat Formation. The upper, carbonate-rich part belongs to the lower Courgenay Formation and forms steep cliffs. The name of ZiegLeR's unit is derived from the smooth brachiopod "Zeilleria humeralis (ROEMER)" that is at present called Zeillerina astarina (ROLLER) as indi- cated by ENAY et al. (1988, p. 314) and figured by Bouluer (1993, pl.1, fig. 5). Zeillerina astartina (ROLLIER) is a poor guide fossil, because it has also been found in the upper Röschenz Member, as in bed 59 of section RG 312 near Souboz BE, bed 38a of section RG 363 near Soyhières JU and in bed 93 of section RG 368 near Chatillon JU. The name Humeralis Beds is also ambiguous, because it has been used by several authors both for the argillaceous succession above the Hauptmumienbank Member and for the limestones below the Verena Member. It was therefore necessary to find new geographical names for these two members.

The predominantly marly unit between the Hauptmumicnbank Member below and the carbonate La May Member above is called Bure Member after section RG 454 (pl. 16) in the exploration well BUR 2 for the Transjurane highway near Bure JU. This inaccessible type section is selected, because the outcrops of the Bure Member are always artificial and never exposed for long. The member begins in section RG 454 with bed 72 and ends with bed 85 .

The base of the Bure Member in the type section is transitional. In effect it is a paraconformity that cannot be recognized in many sections. Fischer (1965a, p. 20) mentioned a quarry near Raedersdorf $F$ where the upper surface of the Hauptmumienbank Member is encrusted by large ostreid bivalves. The top of the Bure Member may also be transitional. It is where the rock becomes calcareous enough to form cliffs. In the distal direction the Bure Member grades into the Oolithe Rousse Member. First red-brown oolite appears at the base of the Bure Member. The thickness of the marl diminishes in the distal direction while the oolite replaces ever higher parts of the marl until the Oolithe Rousse Member replaces the whole Bure Member (see Gygi \& Persoz 1986, pl.1).

\subsubsection{Oolithe Rousse Member}

Synonymy:

Oolithe rousse ROLLIER (1888, p. 61)

Oolithe rousse ZIECLER (1956, p. 8 and fig 12)

Oolithe rousse Grgt \& Persoz (1986, p. 401 and 413)

Oolithe rousse GyGr $(1995, \mathrm{p} .11)$

Rollier (1888, p.61) and Ziegler (1956, p.8) gave a good macroscopic description of this characteristic member. Grol a Persoz (1986, p. 413) provided a microscopic description. ZIEGLER (1956, p.8) gave a reference section for the member and figured its geographical range (fig. 12). The Oolithe Rousse Member is the lateral equivalent of the Bure Member.

\subsubsection{Günsberg Formation}

(new in the rank of a formation)

Synonymy:

Couches de Chátelu Rollier (1888,p.61)

pars Günsberger Schichten GyGl (1969, p.83)

Günsberg-Schichten BoLLIGER \& BuRkI (1970,p. 73)

Günsberg Member Gygl \& Persoz (1986, p. 401)

Günsberg-Schichten GYG (1995, p. 13) 
The Gunsberg Formation was deposited in a narrow belt along the carbonate platform that grades in the proximal direction into the Vorbourg and Röschenz Members and in the distal direction into the basinal Effingen Member (GyGi \& PERsoz 1986, pl. 1). The main body of the Günsberg Formation is oolitic and rimmed the platform deposits of the adjacent Vorbourg and Röschenz Members. In the distal direction the oolite bars contain coral bioherms that grew in somewhat deeper water. Because of the progradational geometry of the formation the coral bioherms cover almost the whole width of the platform at the base of the formation, and the oolite overlies them (fig. 39). Due to the fact that the Gunsberg and laterally equivalent Vorbourg and Röschenz members all prograded basinward their relationship to each other and the underlying formations is complex (fig. 39). The proximal part of the lower Günsberg Formation rests on the distal St-Ursanne Formation. The Gunsberg Formation then prograded over the Effingen Member so that the distal part of the lower Günsberg Formation rests on top of the Effingen Member. In addition, the Röschenz Member prograded over the proximal Gunsberg Formation. Consequently, the upper boundary of the proximal Günsberg Formation is overlain by the upper Roschenz Member and the Hauptmumienbank Member and further in the distal direction by the Stcinebach Member (fig. 39).

Gygr (1969) classified the Günsberg Formation as a member of the Balsthal Formation. The reason was that the Gunsberg Formation is difficult to delineate from the Balsthal Formation in the southernmost Jura range between Mt. Hasenmatt and Mt. Weissenstein (cf. section RG $384, \mathrm{pl} .29$, see also Burkhalter 1989, p. 148 and fig.2-12). Bolliger \& Burri (1970, p. 73) separated the Steinebach Beds of Grot (1969) from the Gunsberg Member and included the Gunsberg Member in the Vellerat Formation. It is probably better to interpret the Günsberg unit as a separate formation between the lagoonal Vellerat Formation and the basinal Wildegg Formation (sce fig. 39). The composition of the Gunsberg Formation is so complex that a subdivision into members is not recommended. The name "Moutier-Korallenkalke" (Moutier corallimestone) of Bolliger \& Burk! (1970, p. 72) for part of the Günsberg Formation is therefore rejected. Hermatypic corals occur both at the base, at the distal margin and within the Günsberg Formation (section RG 381, Court gorge near Moutier BE, pl. 28).

RolLier (1888, p. 62) paid special attention to the coral bioherms in the Rondchâtel cluse near Péry BE (section RG 307 , bed no.160. pl.22) and compared them with a unit containing hermatypic corals that lies above the Effingen Member and had been described by DE TRIBOLET (1872) from Mt. Châteleu in France near the Swiss border (sec Swiss National Map, sheet 1163, Travers, $2.5 \mathrm{~km}$ westnorthwest of La Brévine NE). RoLLER's name Couches de Châtelu, a senior synonym of Günsberg Formation, has never been used again by either French or Swiss authors and is therefore forgotten.

The type section of the Gunsberg Formation is section RG 14 in the Gschlief landslide above Günsberg SO. This is at the distal margin of a narrow carbonate platform where the Gunsberg Formation grades laterally into the Effingen Member. The facies of the formation is therefore atypical at that locality. A good reference section is in the quarry of La Charuque near Péry BE (section RG 307, pl. 22).

The age of the Gunsberg Formation varies from the proximal to the distal realm (fig. 40). This can be secn in fig. 39 and in Gyor \& Persoz (1986, pl.1). In the distal realm, the age ranges from the late Bifurcatus Chron (Gvol, 1995, fig. 17/2) to the Hypselum Subchron (GxGi, 1995, fig. 18).

\subsubsection{Courgenay Formation}

\section{Synonymy:}

Oberste Zone des Sequans Hummel (1914, p. 216)

Courgenay Formation GyGl (1995, p. 12)

The Courgenay Formation is a succession of bedded and massive limestones that is underlain by the argillaceous Bure Member and overlain by the well-bedded limestones of the Reuchenctte Formation.

The lower boundary of the formation is taken where the carbonate content of the succession increases sufficiently so that the limestone forms cliffs or an escarpment. The distal boundary is where the micritic limestone grades into oolite. The upper boundary is less evident. Hummel (1914, p. 12) distinguished a bed of white limestone with a thickness of 3 to $4 \mathrm{~m}$ with abundant fossils. This probably corresponds to the beds 45 and 46 of section RG 340 in the quarry east of Le Banné hill at Porrentruy JU (pl. 17). Hummel regarded this to be the uppermost bed of his "Sequan" (Upper Oxfordian). Tschopp (1960, p.9) called that bed "Bank B". It is uncertain what Tschopp meant by his "Bank A" that he states also to be a white limestone with a thickness of 3 to $5 \mathrm{~m}$. He thinks this is 40 to $45 \mathrm{~m}$ above the Bure Member. Gyat found a porous white limestone with a thickness of $12.7 \mathrm{~m}$ about $30 \mathrm{~m}$ above the Bure Member in his section RG 350 , bed 79, along the Chemin Paulin road near Courgenay JU (pl.19). GyG \& Persoz (1986) proved by clay mineral correlations that the upper boundary of bed 79 in section RG 350 was coeval with the upper boundary of the Verena Member and thus with the upper boundary of the Oxfordian Stage as it was conventionally conceived in Central Europe. Bed 79 of section RG 350 at Courgenay JU (pl. 19) corresponds to bed 88 of seetion RG 340 at Porrentruy JU at the base of the quarry (pl.17). In section RG 340 at Porrentruy, the base of bed 88 is not exposed, but there is a conspicuous limonite crust at its top. It is this bed $(340 / 88,350 / 79)$ of white, chalk-like limestone that can be followed through the whole of the Ajoie as far as Montbeliard in adjacent France where it is called "Calcaire crayeux à Cardium" (GYGI 1995,p.12).

LAuBSCHER (1948, p. 10). SCHNeIder (1960, p. 8) and TsChopp $(1960, p .9)$ were of the opinion that it was impossible to distinguish what GrG (1995. p. 12) called Courgenay Formation from the lower Reuchenette Formation. They consequently mapped the two formations together. It is true that it is impossible to distinguish the limestones of the La May Member (Grat 1995) from most limestones of the lowermost Reuchenette Formation below the Banné Member in the Ajoie at small outcrops. But it is necessary to have a name for the limestone succession between the Vellerat Formation below and the Reuchenette Formation above that both can be easily distinguished in the Ajoie region of 
northwestern Switzerland. This is why GyG (1995, p. 12) proposed the name Courgenay Formation for beds 14 to 79 in section RG 350 ( $\mathrm{pl} .19$ ) along Chemin Paulin road near Courgenay JU. The Chemin Paulin is the type section of the formation. The formation can be followed from St-Ursanne into adjacent France. Gror (1995, p. 12) distinguished two members. The age of the formation ranges from the late Oxfordian Hauffianum Subchiron to the Planula Chron of the carly Kimmeridgian (fig, 40),

\subsubsection{La May Member}

Synonymy:

Humeralis-Schichten (Kalke) ZIEGLER (1956, fig. 14)

Calcaire a Térébratules CHAUVE et al. (1985, p.14)

Humeralis limestone Groi \& Persoz (1986, p. 401)

La May-Schichten GYGl (1995, p. 12)

The La May Member is a succession of well-bedded, micritic limestones that are underlain by the argillaceous Bure Member and overlain by the massive white limestone of the Porrentruy Member. Peloids, oncoids, bio- and small lithoclasts may oceur in the micrite.

The La May Member is found in the whole of the Ajoie region and near St-Ursanne. Southeast of St-Ursanne it interfingers with the Laufen and Verena Members (fig. 39).

GyG1 $(1995$, p. 12) named the member after a section along a forest road south of La May $2.5 \mathrm{~km}$ eastnortheast of St-Ursanne (section RG 337, unpublished) and proposed that the exploration well RG 443 near the farm La Coperie $2.25 \mathrm{~km}$ east of StUrsanne be the type section (beds 24 to $64, \mathrm{pl} .20$ ). because there is no complete natural outcrop of the member. A good reference section is the outcrop along Chemin Paulin road (section RG 350, pl. 19) near Courgenay JU.

\subsubsection{Porrentray Member}

\section{Synonymy:}

pars "Bank A" Тschopp (1960, p. 9)

Calcaires à Cardium Chauve et al. (1985, p. 14)

Chalk-like limestone Gygl \& Persoz (1986, tab. 2)

Porrentruy-Schichten GYol (1995,p. 12)

The Porrentruy Member is a massive, yellowish-white to pure white limestone that is often porous and chalk-like. It is underlain by the bedded, mostly micritic limestones of the La May Member and overlain by the bedded limestones of the lower Reuchenette Formation.

The Porrentruy Member has a mean thickness of about $15 \mathrm{~m}$. It can be followed from St-Ursanne through the Ajoie to at least as far as Montbeliard in France. The best section is RG 350 near Courgenay JU (pl. 19). The Porrentruy Member is bed 79 of section RG 350 that is designated here as the type section. The name of the member is derived from bed 88 in the section RG 340 (pl.17) near Porrentruy where the uppermost $7.8 \mathrm{~m}$ of the member crop out.

\subsubsection{Balsthal Formation}

Synonymy:

Balsthaler Formation GYGJ (1969, p. 83)

Court-Formation Bolliger \& BURRI (1970, p. 73)

pars Vellerat-Formation BoLLIGER \& BURR (1970, p. 71)

Balsthal-Formation Tschum (1983, p. 43)

Balsthal-Formation MARTIN (1984, p. 192)

Balsthal Formation GyGr \& Persoz (1986, p. 401)

Court Formation Gygl \& Persoz (1986,p. 401)

Obere Balsthaler Formation BURKHALter (1989, p. 145)

Balsthal-Formation BALMER (1989,p. 88)

Balsthal Formation ALLENBACH (1994, p. 85)

The Balsthal Formation comprises the limestones that are underlain by the Günsberg Formation and the Effingen Member and overlain by the Reuchenette Formation. Proximally it grades into the upper Vellerat Formation and the Courgenay Formation. The basinal time-equivalent is the Villigen Formation (fig. 39).

The proximal part of the Balsthal Formation can be subdivided into the Steinebach Member below, the Laufen Member in the middle and the Verena Member above. The Steinebach, Olten and Holzflue Members can be distinguished in the distal part of the Balsthal Formation.

The Balsthal Formation extends from a line Glovelier JU Delémont to Olten SO. Bolliger \& Burri (1970, p. 73) proposed the term Court Formation for the sediments between their Vellerat Formation and the Reuchenette Formation. The Court Formation of thesc authors includes the Balmberg oolite, the Hautes-Roches-Algenkalke and the Verena oolite. There are three main types of facies in the late Oxfordian sediments of northern Switzerland: the proximal, lagoonal lime mudstones, the oolite bars of the carbonate platform margin and the basinal lime mudstones (fig. 39, sec also Gyal \& Persoz. 1986. $\mathrm{pl}$. 1). The Courgenay, the Balsthal and the Villigen Formations have been introduced for these facies belts. The Court Formation is mostly oolitic like the Balsthal Formation. It is therefore to be regarded as a junior synonym of the Balsthal Formation and is rejected as being superfluous.

\subsubsection{Steinebach Member}

Synonymy:

Steinibach-Schicht GVGI (1969,p.85)

Steinibach-Schicht BOLLIGER \& BURR $(1970$, p. 73$)$

non Steinibach-Schichten Pfirter (1982, p. 28)

Steinibach Beds Gyal \& Persoz (1986, p. 402)

Steinibach Beds Altenkach $(1994$, p. 91$)$

Steinebach-Schichten GyGi (1995, p. 11)

non Couches de Steinibach Prtret (1996, fig. 19b)

The Steinebach Member is an oolite (mostly oosparite) with a thickness from $4.5 \mathrm{~m}$ to $21.3 \mathrm{~m}$. It was only possible using clay mineralogy to correlate this unit with the proximal Hauptmumienbank Member and the distal Geissberg Member. No ammonites have as yet been found in the Steinebach Member. The upper part of the member may contain oncoids as for instance in the type section RG 438 (pl. 44) in the Steincbach gorge near Balsthal SO. Near Gänsbrunnen SO there are corals and abun- 
dant nerineid gastropods in this unit. The Steinebach Member occurs in the sections RG 430, Gansbrunnen SO (pl.40), RG 429. Welschenrohr SO (pl.39), RG 384.Selzach SO (pl.29), RG 14. Gunsberg SO (GvG1, 1969, pl.18). RG 438, Balsthal SO (pl. 44) and RG 448, Egerkingen SO (unpublished, see fig. 1). The unit has been sedimented during the late Hypselum Subchron (Gyor, 1995, fig. 23).

\subsubsection{Laufen Member}

Synonymy:

Humeralis-Schichten (Kalke) ZIEGLER (1956, fig, 14)

pars Hautes-Roches-Algenkalke Bolliger \& Bukri (1970. p. 74)

Humeralis limestone Grgi \& Persoz. (1986, p.401)

Laufen-Schichten Grgi (1995,p. 13)

No satisfactory name has been proposed by the earlier stratigraphers for this transitional, very variable member that is underlain by the Oolithe Rousse Member and the Steinebach Member and overlain by the Verena Member. In the proximal direction it grades into the Oolithe Rousse Member and the micritic La May Member. The distal time equivalent is the oolitic lower Holztlue Member (fig. 39). The Laufen Member can contain micrite, pelmicrite, oncolite, oolite, oolitic oncolite, dolomitic oncolite or coral limestone. GyGi (1995, p. 13) pre- ferred to introduce a new name, because the Hautes-RochesAlgenkalke of BoLLiger \& BURRI is ambiguous. These authors included at their type locality the well-defined Hauptmumienbank Member in the unit. Moreover, oncoids are by no means ubiquitous in the Hautes-Roches-Algenkalke (HeCKENDORN, 1974. p. 12). Gyol (1995) has based his new name on the town of Laufen BL, where the upper part of this unit has heen worked for a long time and is a well-known building stone in a widespread area. Good reference sections are in the Schachlete valley near Dittingen BL, but only the upper Laufen Member crops out in the quarries in that valley. Therefore, the limestone quarry of the former cement works of Liesberg BL is proposed as type section of the Laufen Member (RG 398, beds 27 to 48 . fig. 35 and pl. 32 ).

\subsubsection{Verena Member}

Synonymy:

Calcaire blane de Ste-Vérène Deson \& Giessly (1859,p. 75)

Hohlenkalk LANG (1863, p. 22)

Calcaire oolithique de Ste-Vérène Greppin (1870, p. 96)

non Verena-Schichten BuxTorf (1907, p. 54)

Couches de St-Vérène JuILLERAT (1907,p. 72)

Verena-Oolith ZiEgLer (1956, p. 56)

Verena-Schicht Groi (1969, p. 86)

Verena-Oolith Bolı.ıGer \& BuRrı (1970, p. 74)

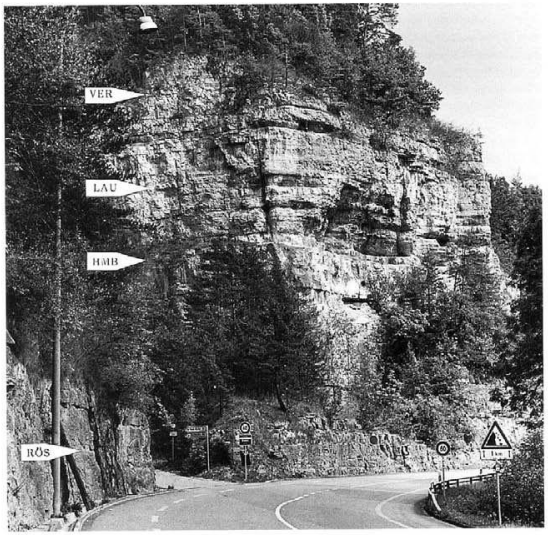

Fig. 35: Entrance to the limestone quarry of the former cement works of Liesberg as seen from the cantonal road. RÖ: Róschenz Member, HMB: Hauptmumienhank Mcmber. LAU:Laufen Member, VER: Verena Member. Section RG 398, compare with pl. 32 . 
Verena-Oolith HeCKendonn (1974, p. 12)

Verena Member Grgl \& Persoz (1986, p.402)

Verena-Schichten GYGI (1995, p. 14)

The Verena Member is a massive, yellowish-whitc oolite with a mean thickness of about $45 \mathrm{~m}$. It is above the Laufen Member and below the Reuchenette Formation. The Verena Member grades proximally into the upper La May and the Porrentruy Members and distally into the upper Holzflue Member. Its lithology is distinctive; the ooids are mostly micritized (GyGi, 1969,pl.13, fig. 47) and oncoids are quite common. The rock has a complicated diagenetic history of partial dolomitization, replacement by calcium sulfate in small patches, and dedolomitization of the whole rock except for occasional small relicts of anhedral dolomite (GYGI, 1969, p. 78). The primary oolitic texture was partially destroyed in the process. The micritized ooids are casily visible on clean. weathered surfaces, but they are difficult to discern on a freshly broken surface. Large pockets of the rock as much as 10 or $20 \mathrm{~m}$ across may be porous and weather out as hollows and caves as for instance behind the Verena chapel near Solothurn, the type locality of the Verena Member (fig. 36). Such pockets occur in any level of the member. Unaltered, eross-bedded oolite is uncommon.

There is considerable disagreement between authors about how to interpret the Verena Member at different localities. BUXTORF (1907, p. 54) and with him ZIEGLFR $(1956$, p.96) and GYG1 (1969, pl.19, section 2) have mistaken the Steinebach Member in section RG 430 at Gänsbrunnen (bed 35, pl.40) as the Verena Member. Therefore, BuxtoRf (1907, p. 58) greatly overestimated the thickness of the Reuchenette Formation at that locality $(130 \mathrm{~m}$ instead of $13 \mathrm{~m}$. see this paper, pl. 40$)$. WiedenMayer $(1923$, p. 4$)$ and STAEHELIN $(1924$, p. 4$)$ assumed that the thickness of the Verena Member was only $15 \mathrm{~m}$, and Gral (1969, p. 87) followed them in this interpretation. BotLIGER \& BURRI (1970,p. 74) pointed out that the thickness of the member could be up to $50 \mathrm{~m}$. The new measurements of sections confirmed this: in section RG 404 near Mervelier JU the thickness of the Verena Member is as much as $57 \mathrm{~m}$ (pl.36). Only the upper part of the member crops out at the type locality of St. Verena north of Solothurn (fig. 36). Complete sections are near Moutier BE (RG 392, pl.26), Rebévelier JU (RG 377 , pl. 25). Delémont (RG 366, pl.23) and Sornetan BE. Pichoux gorge (RG 315,pl. 21). An easily accessible reference section of the Verena Member is RG 392 in the northern part of Moutier gorge north of Moutier BE.

Fossils are uncommon in the Verena Member. There are occasionally abundant nerinean gastropods or coral clasts. Coral bioherms have been found near Lommiswil SO (RG 383, PS Gy $4408-4410$, ca. 110 m east of point 1299 on the crest of the ridge east of Mt. Hasenmatt, about $10 \mathrm{~m}$ above the base of the Verena Member) and near Seehof BE (section RG 419 , in the middle of the Verena Member). There is no record of ammonites in this member. It is only through clay mineral correlations that it could be established that the Verena Member is the time equivalent of the Letxi Member and thus belongs to the Planula Chron (Gyal \& Persoz, 1986, tab. 2).

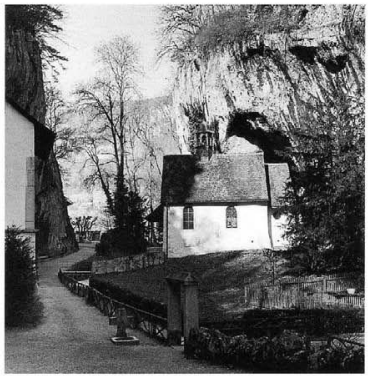

Fig. 36: Hermitage of St. Verena. Rüttenen SO. $2 \mathrm{~km}$ north of Solothurn. Massive oolitic limestone of Verena Member. type locality of the member. The distinct bedding plane above the chapel is the upper boundary of the Verena Member and therefore the boundary between the Balsthal Formation and the Reuchenette Formation.

\subsubsection{Holzflue Member}

Synonymy:

Holzflue-Schichten Grol (1969, p. 86)

pars Holzflue-Schichten Tschumi (1983, p. 54)

pars Holzflue-Schichten Martin (1984, p. 192)

Holzflue-Schichten GyG1 \& PERSOz (1986, p. 402)

Holzflue-Schichten BALMER (1989.p. 100)

Holzflue Member ALLENBACH (1994,p. 94)

Holzflue-Schichten Gror (1995, p. 14)

The Holzflue Member is a succession of yellowish-white, massive oolitic or micritic limestone that lies between the older Steinebach Member and the younger Reuchenette Formation. The upper part of the Holzflue Member has the same facies as the Verena Member. The lower part is very similar. but it can contain oncolitic intercalations. Near Günsberg there are hermatypic corals at the base of the member.

Near Delémont (section RG 366, pl.23) and Moutier BE (section RG 390, pl.27), the Laufen and the Verena Members can be easily distinguished. When one looks north from point 845.1 on the eastern slope of Moutier gorge, a cliff of the Balsthal Formation is visible on the northern limb of the fold. It can be seen from a distance of about $600 \mathrm{~m}$ that the Laufen Member is indistinctly bedded and weathers with a light brownish tinge, whereas the Verena Member above is massive and almost white. In the Weissenstein range east of Solothurn the two members cannot be distinguished any more. A particular name is therefore needed for the region where the two units have to be lumped together. Gvol $(1969, \mathrm{p} .86)$ has proposed the name 


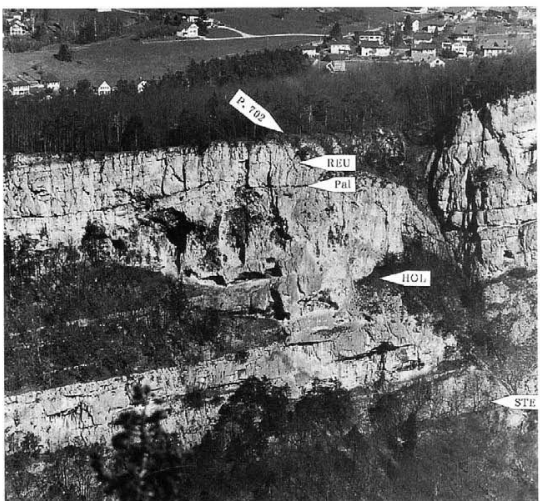

Fig.37: Cliff of Chluser Roggen near Balsthal $\mathrm{SO}$ telow point 702 as seen from Wannenflue at coordinates $618.900237 .810,100 \mathrm{k}$ ing north. STE: Steinebact Member, HOL-Holzflue Member. REU: Reuchenette Formation. Pal: Palacosol in the lowermost Reuchenette Formation, Section RG 450, unpublished.
Holzflue Member after the rocky mountain directly north of Balsthal.

The lower Holzflue Member includes oncoids at varying levels. The oncoid content may attain $20 \%$ of the rock or more in several sections. The lower Holzflue Member thus cannot be clearly delineated from the Laufen Member nor from the upper part of the Steinebach Member.

Wiedenmayer (1923, p.4), Staehelin $(1924$, p. 4), Gyol (1969, p. 86) and ALLENBACH $(1994$, p. 96) distinguished a VCrena Member about $15 \mathrm{~m}$ thick east of Solothurn at the top of the Holzflue Member that weathers back to form a hollow when the strata are steeply dipping. It is advocated here to discard this member of the eastern Weissenstein range, because its lower boundary cannot be satisfactorily defined. Near Balsthal also the upper boundary is indistinct (see below).

The lower boundary of the Holzflue Member in the Steinebach gorge, which is the type locality, is best placed at the top of bed 25 of section RG 438 at Balsthal (pl. 44, this is the same section as RG 9 in GXG1, 1969. pl. 18). The pure white bed RG $438 / 25$ weathers back to form a hollow and separates the low ridge of the Steinebach Member from the high ridge of the Holzflue Member. The upper boundary of the Holzflue Member cannot be clearly defined near Balsthal, because the lower Reuchenette Formation is also oolitic in that region. According to an ammonite figured by GyG $(1995$, fig. 19), the boundary must be a few meters below a palacosol in the lowermost Reu- chenette Formation (bed 52 in section RG 438 at Balsthal, pl. 44. see also fig. 37 and discussion of the boundary in GyGi, 1995 . p. 15). East of Mt. Roggen the micrite content of the Holzflue Member increascs. The unit is mostly mierite where it is in contact with the Olten Member in the east (Grol \& Persoz. 1986, pl. 1).

\subsubsection{Olten Member}

Synonymy:

Crenularisschichten KeHRER (1922, p. 14)

Oltener Korallenkalk Grot $(1969$, p. 94)

Olten coral limestone Gyot \& Persoz (1986, tab, 2)

Olten-Schichten Grai (1995, fig 2)

The Olten Member is a massive limestone with hermatypic corals and a mostly micritic matrix. The coral colonies are typically dish-like and are most often preserved as fine-grained sparite. The most common corals are Siylina, Dimorphoseris and microsolenids. The corals formed small bioherms north of Wangen SO. Near Olten they apparently grew in a vast biostrome.

The Olten Member begins in the distal Steinebach Member and rises diachronously to the upper Holzflue Member in the distal direction (GyGl 1969, pl. 19 and this paper, fig. 39).

The best section of the member is in the quarry of the Olten cement works on the north slope of Mt. Born (section RG 21. beds 29 to 38 in GYGL 1969, pl, 18). 
Fig. 38: Rock of Rouge Pertuis north of Undervelier $J$ as seen from the west. Massive oolitic Verena Member (left) and bedded. mostly micritic lower Reuchenette Formation (right). The strata are vertical.

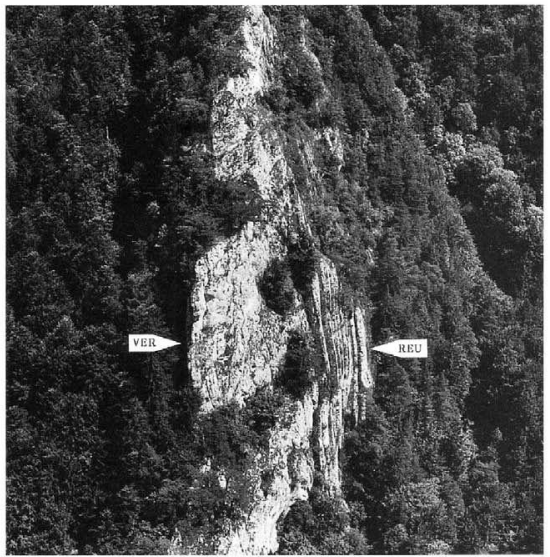

\subsubsection{Reuchenette Formation}

Synonymy:

Reuchenette-Formation ThALMANN (1966, p. 32)

Reuchenette-Formation ScHÄr (1967,p. 11)

Reuchenette-Formation PFIRIER (1982, p. 32)

Reuchenette-Formation Tschum (1983,p.61)

Reuchenette-Formation Martin (1984, p. 194)

Reuchenette Formation GyGl \& PERsoz (1986, p. 403)

Reuchenette-Formation BALMER (1989, p. 111)

Reuchenette-Formation BURKHALTER (1989, p. 177)

Reuchenette Formation AlLENBACH (1994, p. 108)

Reuchenette-Formation HAUSER (1994, p. 46)

Reuchenette-Formation GyGl (1995, p. 14)

Kimméridgien Movchet (1995)

The Reuchenette Formation is a thick succession of carbonate platform sediments ranging from pure micrite to oosparite. Coral bioherms are few and of a small size, and they mainly occur at the platform margin near Balsthal SO (GyGr \& Pcnsoz, 1986. pl. 1B). No complete section of the formation is presented in this paper.

The boundary between the massive Verena Member and the well-bedded Reuchenette Formation may be conspicuous at some localities (fig. 38). Several authors have distinguished members in the Reuchenette Formation (fig.40). However, these members cannot be correlated over greater distances. The type section of the Reuchenette Formation is near La Reuchenette at Péry BE (ThaLmann 1966, fig. 5). The ramp facies with ammonites between Balsthal $\mathrm{SO}$ and Schonnenwerd $\mathrm{SO}$ in the east is included in the Reuchenette Formation in order to avoid having to give a new name to this erosion relict.

The age of the base of the Reuchenette Formation corre sponds to the base of the Baden Member in Canton Aargau. This coincides with the beginning of the Platynota Chron (fig. 40). The correlation is based on clay minerals (GYGi \& PERsoz 1986) and is corroborated by ammonites (GYGl 1969, pl. 17. section RG 70, GrG1 1995, fig. 19). The boundary between the Oxfordian and the Kimmeridgian Stages was conventionally assumed to be between the Planula Zone, Galar Subzone, and the Platynota Zone in Central Europe (MouTERDE et al.., 1971). This boundary had the advantage that it was mappable throughout northern Switzerland. But following a paper by Schweigert \& CALLOMON (1997) the boundary has now to be drawn deeper down (see paragraph 5.6 below). 

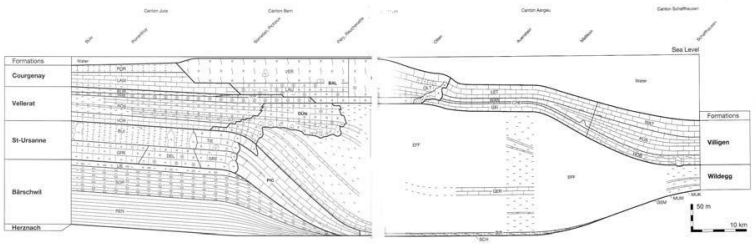

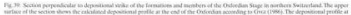

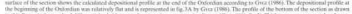

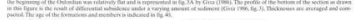
alt Bdowifineretion

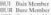
taE Cresulans Sink
iw trivemserter
ois conste Mielve

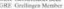

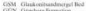

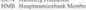

fon homel Nered

Kos. Kimetors Minter

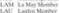

IT Irivinater
\end{abstract}

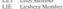

Ming Memiabs Hod

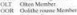

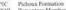

Nos Domening Mede

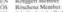

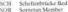

SII Sienched Mraies

VER Linestemter.

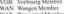

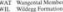




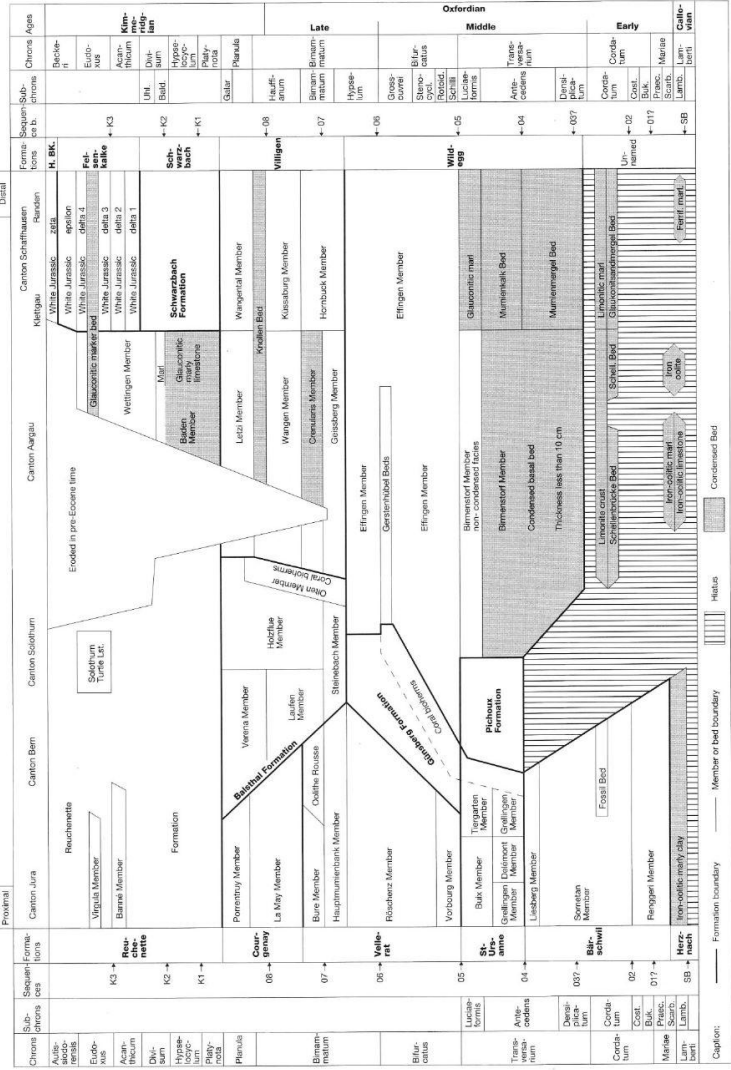




\section{Biostratigraphy}

\subsection{Stratigraphically significant ammonite taxa}

The following ammonite descriptions are short, because most of the taxa are well-known. There are no revisions of species. The descriptions relate exclusively to the figured specimens. The synonymy lists include only the principal ammonite figures in the literature. If a modern revision of an ammonite group is available, the synonymy list only goes back to that publication.

Suborder Ammonitina Hratr 1889

Superfamily Haplocerataceae ZITTEL 1884

Family Oppeliidae Bonarelu 1894

Subfamily Glochiceratinae HYaTt 1900

Genus Ochetoceras Haug 1885

Type species: Ammonites canaliculatus voN Buch 1833, designated by MUNIER-CHALMAS (1892,p. CLXXI).

Gygi \& von Hillebrandt (1991,p. 148) stated that the holotype of voN BuCH is from Erlinsbach, Canton Aargau. It is from the non-condensed, normal facies of the Birmenstorf Member and therefore from the Luciaeformis Subzone. It has, as indicated by OPpel (1862, p. 158), three keels. A plastic cast (J 31177) of the lost holotype is kept at the Museum of Natural History, Basel (MNHB).

\section{Subgenus Ochetoceras Haug 1885}

Subgeneric type species: Ochetoceras (Ochetoceras) canaliculatum (VoN BuCH 1831).

\subsubsection{Ochetoceras (Ochetoceras) hispidum (OPPEL 1863) \\ Pl. 3, fig. 3}

\section{Synonymy}

1964 Ocheroceras (Ochetocenas) hispidum (OPPEL) - HöвoL DT, p. 55. pl. 3. fig. 3,4 with synonymy

1974 Ochetoceras hispidum (OPPEL) - BArsulnscu, pl. 36, figg.5, 10

1977 Ochefoceras hispidim (OPPEL) - ZiEGIER, pl.1, fig. 2

1991 Ochetoceras (Ochetocenas) hispidum (OPPEL) - ScHLampe, pl. 33. fig. 2

1994 Ochetoceras (Ochetoceras) hispidum (OPPEL) - SCHLEGELMILCH. p. 47, pl. 14, fig. 8

\section{Material: MNHB J 25901}

Locality: section RG 81b, GyG (1977, pl.11, fig. 6), excavation below Räckolterenbuck, Gächlingen SH, bed 14b, upper Mumienkalk Bed.
Description: Diameter

Whorl height

Whorl thickness

Umbilicus

D $\quad 58 \mathrm{~mm}$

Wh $33 \mathrm{~mm} \quad 57 \%$

Wt $18 \mathrm{~mm} \quad 31 \%$

U - $14 \%$

The glauconitic, carbonate internal mould (steinkern) is wholly septate. The lateral groove is first conspicuous and then fades away in the course of ontogeny. There is a single median keel on the siphuncular side that is minutely serrated. The strong, slightly arcuate primary ribs are completely interrupted where the lateral groove is deep. The secondary ribs are somewhat broader than the primaries. The greatest whorl thickness is near the umbilical margin.

Age: late Antecedens Subchron of the Transversarium Chron.

Genus Neoprionoccras SPATH 1928

Type species: Oppelia girardoti DE LORIoL 1902

\subsubsection{Neoprionoceras delmontanum (OPPEL 1863) Pl.2, fig. 9}

Synonymy

1961 Campvlites (Campylites) delmontanus delmontanus (OPPEL) - CHRIST, p. 293, pl.17. fig 2, with synonymy

1963 Canpylites delmontanus (OPPEL)-MaLrvowski, p.37.pl.8. fig. 54 , pl. 9 , figs $56-57$

1977 Campylites (Campylites) delmonionus delmontanus (OPPEL) - Bourseau. p.96.pl.9. fig. 5

non 1991 Ocheroceras (Campylites) delmontanum (OPPEL) PAGE,p. 94, pl. 13, figs 5,6

1991 Campylites (Campylites) delmontanurs (OPPEL) - Scutasmr, pl. 33, fig. 10

Material: MNHB J 25052

Locality: section RG 208, GYG (1977, pl. 11, fig, 2), excavation on Brunnrain, Uken AG, bed 9, upper Schellenbrücke Bed.

Description: Dimensions D $42 \mathrm{~mm}$

$\begin{array}{ccc}\text { Wh } & 20 \mathrm{~mm} & 48 \% \\ \text { Wt } & 11 \mathrm{~mm} & 26 \% \\ \text { U } & 11 \mathrm{~mm} & 26 \%\end{array}$

The iron oolitic, carbonate internal mould is wholly septate. The greatest thickness of the whorl is near the rounded umbilical margin. The strong, almost straight primary ribs are prorsiradiate and fade out completely along a narrow smooth band slightly below the middle of the whorl sides. There are two slightly arcuate secondary ribs per primary. The secondaries be- 
come stronger and broader towards the siphonal side and touch the well-developed marginal keels. The median keel is only a little higher than the marginal ones.

Age: Iate Cordatum Subchron of the Cordatum Chron.

\section{Genus Trimarginites ROLuer 1909}

Type species: Ammoniles trimarginatus OPPEL 1863, designated by Rollier (1911, p. 309), see also discussion by CHRIST (1961, p. 283).

\subsubsection{Trimarginites trimarginatus (OPPEL 1863)}

Pl. 7, fig. 4

Synonymy
1963 Trimarginites trimarginatus (Opp.) - MaLinowska, p. 39, pl. 10. fig 60

1973 Trimarginites trimarginatus (OPPEL) - SAFUnov, p. 108, pl. 1, fig. 6

1974 Trimarginites trimarginatum (OPPEL) - BARBULESCU, pl,36. fig. 1

1977 Trimarginites arolicus (OPPE.) - ZIEGLER, pl. 1, fig. 5

1991 Trimarginites cf. trünarginatus (OPPEL) - SCHLAstPP, pl.34, fig. 2

1994 Trimarginites trimarginalus (OMPI) - SCHLEGi rML.CH, p. 47. pl. 14 , fig. 5

Material: MNHB J 25924

Locality: section RG 81b, Gror (1977, pl.11, fig.6), cxcayation below Răckolterenbuck, Gächlingen $\mathrm{SH}$, bed $14 \mathrm{~b}$, upper Mumienkalk Bed.

$\begin{array}{llrl}\text { Description: Dimensions } & \text { D } & 62 \mathrm{~mm} & \\ \text { Wh } & 33 \mathrm{~mm} & 53 \% \\ \text { Wt } & 15 \mathrm{~mm} & 24 \% \\ \text { U } & 8 \mathrm{~mm} & 13 \%\end{array}$

1961 Trimarginites trimarginatus (OPPEL)- CHRısт, p. 286, pl. 16, fig. 1. with synonymy

\begin{tabular}{|c|c|c|c|c|}
\hline Superfamily & Family & Subfamily & Genus & Subgenus \\
\hline Haplocerataceae & Oppeliidae & $\begin{array}{l}\text { Glochiceratinae } \\
\text { Taramelliceratinae } \\
\text { Streblitinac }\end{array}$ & $\begin{array}{l}\text { Ochetoceras } \\
\text { Neoprionoceras } \\
\text { Trimarginites } \\
\text { Taramelliceras } \\
\text { Creniceras } \\
\text { Streblites }\end{array}$ & $\begin{array}{l}\text { Ochetoceras } \\
\text { Proscaphites } \\
\text { Metahaploceras }\end{array}$ \\
\hline Stephanocerataceae & Cardioceratidae & Cardioceratinae & $\begin{array}{l}\text { Quenstedtoceras } \\
\text { Cardioceras } \\
\text { Amoeboceras }\end{array}$ & $\begin{array}{l}\text { Scarbirgicenas } \\
\text { Pavloviceras } \\
\text { Cardioceras } \\
\text { Subvertebriceras } \\
\text { Maltoniceras } \\
\text { Miricardioceras }\end{array}$ \\
\hline Perisphinctaceae & $\begin{array}{l}\text { Perisphinctidae } \\
\text { Ataxioceratidac } \\
\text { Aulacostephanidae } \\
\text { Pachyceratidae } \\
\text { Aspidoccratidac }\end{array}$ & $\begin{array}{l}\text { Perisphinctinae } \\
\text { Idoceratinae } \\
\text { Ataxioceratinae } \\
\text { Pictoninae } \\
\text { Aulacostephaninae } \\
\text { Peltoceratinac } \\
\text { Euaspidoceratinae } \\
\text { Aspidoceratinae }\end{array}$ & $\begin{array}{l}\text { Perisphinctes } \\
\text { Stibdiscosphinctes } \\
\text { Larcheria } \\
\text { Passendorferia } \\
\text { Wegelea n: } \\
\text { Idoceras } \\
\text { Subnebrodites } \\
\text { Oritosphincres } \\
\text { Ataxioceras } \\
\text { Ringsteadia } \\
\text { Rasenia } \\
\text { Sutneria } \\
\text { Protophites } \\
\text { Gregoryceras } \\
\text { Euaspidoceras } \\
\text { Epipeltoceras } \\
\text { Orthaspidoceras }\end{array}$ & $\begin{array}{l}\text { Neomorphoceras } \\
\text { Otosphinctes } \\
\text { Arisphinctes } \\
\text { Dichotomosphinctes } \\
\text { Dichoramoceras } \\
\text { Subdiscosphincies } \\
\text { Aureinonfanites } \\
\text { Passendorferia } \\
\text { Enayites } \\
\\
\text { Oritosphincies } \\
\text { Praeataxioceras } \\
\text { Parataxioceras } \\
\text { Eurasenia } \\
\text { Sutheria } \\
\text { Pseudogregoryceras } \\
\text { Gregoryceras }\end{array}$ \\
\hline
\end{tabular}

Tab. 2: Systematic overview of the figured ammonite genera and subgenera. Mainly after ARkELL el al. (1957) and DoNovAN et al. (1981). 
The glauconitic, carbonate internal mould is wholly septate. The slightly convex whorl sides have a hardly perceptible lateral canal. The delicate, almost invisible primary ribs end this canal. These faint features can only be discerned on particularly well-preserved specimens and have not been described by earlier authors. The secondary ribs are low and broad. There are eight secondaries on the last half whorl. The greatest whorl thickness is between the umbilical margin and the lateral canal. The umbilical margin is a conspicuous edge. The median keel is only slightly higher than the marginal keels.

Age: late Antecedens Subchron of the Transversarium Chron.

\subsubsection{Trimarginites stenorhynchus (OPPEL 1863) pl. 7 , fig. 3}

\section{Synonymy}

1961 Trimarginites stenorhynchus (OPpet) - CHR1ST, p. 288, pl. 16. figs $4-5$, with synonymy

1991 Trimarginites sienorflynchas (OPPEL) - SCALAMrP. pl. 34. fig. 1

1994 Trimarginites stenorfiynchus (OPPEL) - SCHIEgEL.MIICH. P. 46. pl. 14. fig. 4

Material: MNHB J 27372

Locality: section RG 276, Grat et al (1979, fig. 3), Chalch quarry, Holderbank AG, bed 34, upper Birmenstorf Member.

$\begin{array}{llrl}\text { Description: Dimensions } & \text { D } & 44 \mathrm{~mm} & \\ & \text { Wh } & 20 \mathrm{~mm} & 45 \% \\ \text { Wt } & 9 \mathrm{~mm} & 20 \% \\ & \text { U } & 9 \mathrm{~mm} & 20 \%\end{array}$

The carbonate internal mould is septate to the diameter of ca $28 \mathrm{~mm}$. The body chamber is complete and occupies two thirds of the last whorl. The peristome is falcate. The lappets are not preserved. The compressed inner whorls are smooth. Four low, swollen secondary ribs are visible on the body chamber near the peristome. The median keel is only slightly higher than the lateral ones. There is a pronounced egression of the umbilical suture line on the last half whorl.

Age: Luciaeformis Subchron of the Transversarium Chron.
Subfamily Taramelliceratinae SPATH 1928

Genus Taramelliceras DEL CAMPANA 1904

Subgenus Proscaphites RoLlier 1909

Subgeneric type species: Ammonires anar (OPPEL 1863)

\subsubsection{Taramelliceras (Proscaphites) anar} (OPPEL 1863)

Pl. 7,fig.2

\section{Synonymy}

1955 Taranelliceras (Proscaphiles) amar (OPPEL) - HöLDER.p. 81. pl. 16, fig. 3, with synonymy

v 1966 Taramellicaras (Proscapitites) anar (OPPEt) - GvGi, p. 938. pl.4. fig. 2

1967 Proscaphites anar (OPPEL) - MALINowsKa. p. 78.pl.2, fig. 6

v 1977 Taramellicerias anar (OPPEL) - MAtrIs, tab, 2, pl.3. fig, 10

1991 Taramelliceras (Proscaphites) anar (OPPE.)-SCHLAMPp, p. 81. pl. 27 , fig. 6

1994 Taraneliceras (Proscophiles) anar (OPPEL) - SCH EGELMLCH, p. 32 , pl. 7 , fig. 13

Material: MNHB J 25960

Locality: section RG 81b, Gve (1977, pl. 11, fig. 6), excavation below Räckolterenbuck, Gachlingen SH, bed 14b, upper Mumienkalk Bed.

$\begin{array}{llrl}\text { Description: Dimensions } & \text { D } & 34.0 \mathrm{~mm} & \\ & \text { Wh } & 16.0 \mathrm{~mm} & 47 \% \\ \text { Wt } & 10.6 \mathrm{~mm} & 31 \% \\ & \text { U } & 5.4 \mathrm{~mm} & 16 \%\end{array}$

The glauconitic, carbonate internal mould is septate to the diameter of $24 \mathrm{~mm}$. The body chamber occupies one half of the last whorl. The ribs are fine and nearly radial on the phragmocone. On the body chamber they become falcate. There the primary ribs oceur at irregular intervals. At balf the whorl height they split into two to six secondary ribs. The secondaries first bend slightly backward, then forward on the siphonal margin. They form a proconvex are on the siphonal side. On the siphonal margin of the body chamber there are four pairs of elongate elavi. The elongation is along the spiral line. The siphonal side is rounded except at the end of the body chamber. There the siphonal side is somewhat flattened and bears a low, rounded keel. The secondary ribs pass uninterrupted over the keel. An irregularity of the coiling is characteristic for the species: near the aperture the siphonal line bends inward whereas there is a pronounced egression of the umbilical suture line. Therefore the whorl height of the body chamber increases only little from the end of the phragmocone to the aperture.

Remark: The photograph of Taramellicers (Proscaphites) anar (OPPEL) in Hölder (1955, pl. 16. fig. 3) is at the seale of 2:1. The author did not state this fact in the caption to the plate on p. 146 nor in the description on p. 81 where no dimensions are given. But after the description of the taxon he draws attention to fig. 29 in Beilage 1 and states that this figure is at the scale of 
$\times 2$. The size of the drawing corresponds to the size of fig. 3 in pl. 16 .

Age: late Antecedens to Luciaeformis Subchron.

\section{Subgenus Metahaploceras SPATH 1925}

Subgeneric type species: Ammoniter strombecki OpPel. 1857. designated by Hóder (1955, p. 70).

\subsubsection{Taramelliceras (Metahaploceras) wenzeli}

(OPPEL 1863)

Pl. 11, figs. 2-3

Synonymy

1983 Taramelliceras (Metahaploceras) wertzeli (OPPEL) - Schatrer. p. 39, pl.1. figs, $12-15$, with synonvmy.

1994 Taramelliceras (Merahaploceras) wenzeli (OppL) Schlegiemich, p. 37, pl. 10, fig. 6

Material: MNHB J 32276

Locality: section RG 78, Gygl (1969, pl. 16), Mülitobel, Wilchingen SH, bed 60, Wangental Member.

Description: Dimensions D $32.0 \mathrm{~mm}$

\begin{tabular}{|c|c|}
\hline Wh & $18.0 \mathrm{~mm}$ \\
\hline$W_{t}$ & - \\
\hline $\mathrm{U}$ & $3.5 \mathrm{~mm}$ \\
\hline
\end{tabular}

The carbonate internal mould is septate to the diameter of ca $15 \mathrm{~mm}$. The last half whorl is formed by the body chamber. The original description by OPPEL (1863, p.206) agrees very well with the specimen $\mathrm{J} 32276$. The falcate ribs begin at the umbilical suture line. The ribs are first strong, but from the middle of the whorl sides they are attenuated. At the siphonal margin they fade away completely. The rounded siphonal side of the last whorl is smooth. Faint intercalated ribs appear in the middle of the whotl sides. The strong ribs are somewhat approximated near the aperture. This is an indication that the specimen is adult. The Taramelliceras (Metahaploceras) wenzeli J 32277 (pl. 11, fig. 3) from the Knollen Bed of Mellikon is more densely ribbed and there are no intercalated ribs.

Age: Latest Bimammatum Chron to carly Planula Chron.
Genus Creniceras Munier-Chalmas 1892

Type species: Ammonites renggeri OppeL 1863

\subsubsection{Creniceras renggeri (OPPEL 1863) \\ Pl. 1.fig. 6.7}

Synonymy

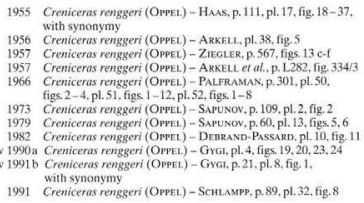

Material: MNHB J 31089, J 31117

Locality: section RG 280. Gral (1990a, fig. 2), clay pit of Ampthil, Liesberg BL, lower part of bed 7, Renggeri Member.

$\begin{array}{ll}\text { Description of J 31089: Dimensions } & \text { D } 26.5 \mathrm{~mm} \\ & \text { Wh } 9.0 \mathrm{~mm} 34 \% \\ & \text { Wt } 7.0 \mathrm{~mm} 26 \% \\ & \text { U } 8.6 \mathrm{~mm} 32 \%\end{array}$

The internal mould of iron sulfide is septate to the diameter of $18 \mathrm{~mm}$. The body chamber occupies more than half of the last whorl. A constriction before the peristome is visible at the end of the body chamber. The specimen is a complete adult to judge of the strong egression of the umbilical suture line on the last whorl. There are some very fine radial, hardly perceptible ribs at the diameter of $10 \mathrm{~mm}$. These ribs are only visible on the siphonal half of the whorl side. The siphonal teeth begin at the diameter of $14 \mathrm{~mm}$ and are prominent from the diameter of $18 \mathrm{~mm}$. The last two tecth before the peristome are attenuated.

Discussion: see Gror (1991b,p. 14). The nomenclatorial and taxonomic problems relating to this taxon have been dealt with by GYG (1991a).

Age: The figured, typical specimens are from the Scarburgense Subchron of the Mariae Chron. The vertical range of closely related forms continues into the Cordatum Zone. 
Subfamily Streblitinae SРАпH 1925

Genus Streblites Hratt 1900

Type species: Ammonites tenuilobatus OpPeL 1858

\subsubsection{Streblites tenuilobatus (OPpel 1858)}

Pl. 14, fig. 4

\section{Synonymy}

1964 Streblites tenuilobatus tenutilobatus (OPPEL) - HöroLdr, p. 23, pl. 1 . figs. 1-3, with synonymy

1977 Streblites tentrilobautus (OPPEL) - ZieGLER, pl. 3. fig. 6

1991 Streblites tonuilobatus (OFFIL) - ScHLAmpr, pl. 31, fig. 2

1994 Sireblites tenuilobartus (OPPEL) - SCHLEGELMLLCH, p. 43, pl. 12 , fig. 13

\section{Material: MNHB J 32269}

Locality: section RG 70, GrGI (1969, pL.17), large quarry, Mellikon AG, bed 124, lower Baden Member.

$\begin{array}{llr}\text { Description: Dimensions D } & 42 \mathrm{~mm} & \\ \text { Wh } & 25 \mathrm{~mm} & 60 \% \\ \text { Wt } & 12 \mathrm{~mm} & 29 \% \\ & \text { U ca. } 3 \mathrm{~mm} & \text { ca. } 7 \%\end{array}$

The glauconitic, carbonate internal mould is wholly septate. There are ten fine, low, slightly prorsiradiate primary ribs on the last half whorl that fade out near the middle of the whorl sides where there is a spiral row of delicate tubercles. One tubercle is associated with every primary rib. The faint secondary ribs begin close to the siphonal margin. There are about seven secondaries per primary rib. The secondary ribs fade away on the siphonal side and do not touch the keel. Only traces of the hollow, sharp keel are preserved.

Age: Hypselocyclum Chron.

Superfamily Stephanocerataceae NEUMAYr 1875

Family Cardioceratidae SIEMIRADZKI 1891

Subfamily Cardioceratinac SIEMIRADZKI 1891

Genus Quenstedtoceras HyatT 1877

Type species: Ammonites leachi SowERBY 1819

\subsubsection{Quenstedtoceras lamberti lamberti (SOWERBY 1819) \\ Pl. 1, fig. 1}

\section{Synonymy}

1970 Quenstedtoceras (1..) lamberi lamberti, morphotype lamberit (SOWERRY) - MaRChaND, p. 63,pl.7. fig, 1-4,pl.8. fig. 1-14. with synonymy

V 1982 Quenstedroceras lamberti lamberti (SowERBY) - MARCHAND, in Gygi \& Marchand, pl. 1, fig. 1-3

1986 Quenstedoceras Lamberti (Sowerny) - MArchAnd, p. 247.pl. 4. fig, 1-2,5-6,pl.5. fig. 1-2,6,10, with synonymy
1991 Quenstedtoceras lamberti (SOWERBY)-PAGE, p. 113, pl. 17, fig. 7,8 , non $\mathrm{pl}$. 18 , fig. 8,9 .

\section{Material: MNHB J 31715}

Locality: section RG 60, Grat (1969, pl.17), Eisengraben, Gansingen AG, bed 3, Schellenbrücke Bed.

Description: Dimensions D $95 \mathrm{~mm}$

$$
\begin{array}{ccc}
\text { Wh } & 38 \mathrm{~mm} & 40 \% \\
\text { Wt } & 26 \mathrm{~mm} & 27 \% \\
\text { U } & 28 \mathrm{~mm} & 29 \%
\end{array}
$$

The iron oolitic, carbonate internal mould is septate to the diameter of about $73 \mathrm{~mm}$. It is a complete adult macroconch with the peristome. The inner whorls are compressed. At the beginning of the body chamber the whorl thickness increases more than proportionally and so does the height of the steep umbilical wall. At the peristome the umbilical wall becomes rounded. The aperture has thus an oval cross-section. The ribbing fades already on the last half whorl of the phragmocone and disappears on the body chamber.

Age: Lamberti Subchron of the Lamberti Chron.

Genus Cardioceras NeUMaYR \& UHLIG 1881

Subgenus Scarburgiceras Buckman 1924

Subgeneric type species: Ammonites scarburgensis YouNG \& BIRD 1828

\subsubsection{Cardioceras (Scarburgiceras) paucicostatum LANGE 1973} Pl. 1, fig. 2

\section{Synonymy}

1973 Cardiaceras (Scarburgiceras) paucicostatum sp. n, - LavaE, p. 90 , pl. 20, figs $3,4,6,9$

1983 Cardioceras (Scarburgiceras) paucicostatum LANGEWriGHI, pl. 18, figs 2-3

1986 Cardioceras paucicostatum LANGe-MArchand, p. 287, pl.7. figs, $1-5,7,9$, with synonymy

v 1990a Cardioceras (Scarburgiceras) paucicostaum Livak-GyG1, p. 179 , fig. 2, pl.3, figs 12,14

1991 ? Quenstedtoceras paucicosiatum (LANGE) - PAGE, p. 114. pl. 17, fig 9

Material: MNHB J 31219

Locality:section RG 280, Grar (1990a, fig. 2), clay pit of Ampthil, Liesberg BL, lower part of bed 6, upper Herznach Formation.

Description: The marly, iron oolitic internal mould of this specimen is so incompletely preserved that it cannot be measured. The inner whorls are flattened. At least a part of the body chamber is preserved. There are ca. 21 primary ribs on the last whorl. The secondary ribs begin in the middle of the whorl sides between the primary ribs. There are less than two sccondary ribs per primary rib. No keel is visible. 
Age: The specimen has been found in the lowermost part of bed 6 in section RG $280(\mathrm{pl}, 30)$ together with Quenstedtoceras lamberii lamberti. The vertical range of Cardioceras pancicostatum straddles on the Middle/Late Jurassic boundary, the boundary between the Lamberti and Scarburgense Subzones (MARCHAND \& ForTwENGLeR (1994,p. 79, fig. 21)).

\subsubsection{Cardioceras (Scarburgiceras) scarburgense (Young \& BIRD 1828) Pl. 1, figs. 3-5}

Synonymy

1986 Cardioceres scarturgense (Young \& BIRD) - Marchand. p. 303. pl.8. fig. 2. with synonymy

y 1990 a Cardioceras (Scarburgiceras) scarburgense Young \& BIRD Grol, pl.3, figs, 1, 2, 4, pl. 4 , figs 21,22

v 1990a Cardioceres (Scarburgiceras) woodhamense ARKELL - GyGI. pl.3. fiz. 5

1991 Cardioceras (Scarburziceras) scarburgense (Young \& BuRD) Schlampr.p. 94 , pl. 34, fig. 6

1994 Cardioceras (Scarburgiceras) scarburgense scarburgense (Young \& BIRD) - SCHLEGELMILCH, p. 23, pl.3, fig.2

Material: MNHB J 31103, J 31104, J 31229

Locality of J 31103 : section RG 280, GrGI (1990a, fig. 2), clay pit of Ampthil, Liesberg BL, bed 7, Renggeri Member. $1.2 \mathrm{~m}$ above the base

Description of J 31103: Dimensions

D $29.0 \mathrm{~mm}$
Wh $13.5 \mathrm{~mm} 47 \%$
Wt $9.5 \mathrm{~mm} 33 \%$
U $\quad 7.0 \mathrm{~mm} 24 \%$

The internal mould of iron sulfide of J 31103 is wholly septate. The primary ribs are radial. There are 11 of them on the last half whorl. The primary ribs either split into two secondaries just below half the whorl height, or they continue undivided and bend forward towards the siphonal side. In the second case there is an intercalated secondary rib, so that there are two secondary ribs per primary rib in all. There is no keel on this specimen, but on the larger specimen J 31229 (pl. 1, fig. 5) the beginning of an indistinct keel can be discerned on the last half whorl.

Age: Scarburgense Subchron of the Mariae Chron.

\subsubsection{Cardioceras (Scarburgiceras) praecordatum DOUVILLE 1912 Pl. 1, figs. $8-9$}

Synonymy

1986 Cardioceras praecondatum DOLVHLE - MARCHAND. p. 323 , pl.9, figs. 7-9, 13, pl. 10. figs 5, 10-15, with synonymy y 1990a Cardioceras (Scarbargiceras) praecordatum DouviLE Grgı, pl.4. fig, 8, pl.5, fie, 3, pl.6, fig, 4
1994 Cardiocenas (Scarburgiceres) praccordatum DouvILLE SCHLFEELMILCH. p. 24, pl.3.fig, 4

\section{Material: MNHB J 30949. J 31114}

Locality: section RG 280, Grgi (1990a, fig. 2), clay pit of Ampthil, Liesberg BL, bed 7, Renggeri Member, J $311143.5 \mathrm{~m}$ above the base, J $3094927 \mathrm{~m}$ above the base.

$\begin{array}{llrl}\text { Description of J 31114: Dimensions D } & 34 \mathrm{~mm} & \\ \text { Wh } & 14 \mathrm{~mm} & 41 \% \\ \text { Wt } & 8 \mathrm{~mm} & 24 \% \\ \text { U } & 10 \mathrm{~mm} & 29 \%\end{array}$

The internal mould of iron sulfide is septate to the diameter of $30 \mathrm{~mm}$. The radial primary ribs are numerous and fine. There are 35 of them on the last whorl. The majority of the primary ribs split at half the whorl height into two secondary ribs that bend forward. There is a distinct keel.

Age: Praecordatum Subchron of the Mariae Chron.

\subsubsection{Cardioceras (Scarburgiceras) bukowskii MAIRE 1938}

Pi. 1,fig. 11

Synonymy

1986 Cardiocetas bukowsku Matre-Marchand, p. 339, pl. 11. fig. 1,pl. 12. fig. 2

v 1990a Cardioceras (Scarburgiceras) bukowshii MAIRE - GyGi,pl.7. figs: 1,3

1994 Cardioceras (Scarburgiceras) bukowskii Marke SCHLEGELMILCH. p. 24.pl. 3, fig. 5

\section{Material: MNHB J 30948}

Locality: Creekbed northwest of La Comée, Rebévelier JU. Renggeri Member, not in situ. An ill-preserved representative of this species collected from in situ has been figured by Grot (1990a, pl. 6. fig. 1).

$\begin{array}{llll}\text { Description: Dimensions of J } 30948 \text { D } & 32 \mathrm{~mm} & \\ \text { Wh } & 15 \mathrm{~mm} & 47 \% \\ \text { Wt } & 9 \mathrm{~mm} & 28 \% \\ \text { U } & 7 \mathrm{~mm} & 22 \%\end{array}$

The internal mould of iron sulfide is wholly septate. There are 38 primary ribs on the last whorl. These ribs are radial. Some of them are unsplit, but the majority splits somewhat below half the whorl height into two secondary ribs. The whorl thickness is greatest where the primary ribs split. The keel is well-developed.

Discussion: Cardioceras bukowskii is similar to its ancestor $\mathrm{Car}$ dioceres praecordatum. The principal difference between the two forms is that Cardioceras bukowskii has a narrower umbilicus than Cardioceras praecordatum.

Age: Bukowskii Subchron of the Cordatum Chron. 
Subgeneric type species: Quenstedtoceras pavlowi DouvLLE 1912

\subsubsection{Cardioceras (Pavloviceras) cf. mariae (D'ORBIGNY 1848) \\ PL. 1, fig. 10}

Synonymy

v 1982 Cardioceras (Pavloviceras) cf. mariae (D'Oratasy) GYGI \& MARCHAND, pl. 2, fig. 7

\section{Material:MNHB J 25206}

Locality: Section RG 209, GrGI (1977, pl.11, fig. 1), Herznach iron mine. Herznach $\mathrm{AG}$, not in situ.

Description: Dimensions D $46 \mathrm{~mm}$

$\begin{array}{lll}\text { Wh } & 21 \mathrm{~mm} & 46 \% \\ \text { Wt } & 24 \mathrm{~mm} & 52 \% \\ \text { U } & 13 \mathrm{~mm} & 28 \%\end{array}$

The iron oolitic, carbonate internal mould is septate to the diameter of $32 \mathrm{~mm}$. The body chamber occupies the last half whorl. The whorls are thicker than high, and the siphonal side is rounded. There are 18 primary ribs on the last whorl. Most of them do not bifurcate, because the majority of the secondary ribs is intercalated. The primary ribs are high and sharp. They have their highest elevation in the middle of the whorl sides and become attenuated at the siphonal side.

Discussion: The specimen cannot be assigned to Cardioceras (Pavloviceris) mariae (D'Orbigin), because the whorls are too thick and the siphonal side is rounded. The ribs form a more distinct chevron on the siphonal side than is indicated by DOORBIGNY (1847, pl. 179, fig. 6) for his marice.

Age: Scarburgense Subchron of the Mariae Chron.

Subgenus Cardioceras Neumayr \& Uhlig 1881

Subgeneric type species: Ammonites cordatus SOWERBY 1813

\subsubsection{Cardioceras (Cardioceras) costicardia vulgare ARKELL 1946 PI. 2, fig.1}

Synonymy

v 1995 Cardioceras (Cardioceras) costicardia valgare ArKell. - Grat. fig. 3/2, with synonymy

Matcrial: MNHB J 31646

Locality: Creek bed northwest of La Cornée, Rebévelier JU, Renggeri Member.
Description: Dimensions D $49 \mathrm{~mm}$

Wh $21 \mathrm{~mm} \quad 42 \%$

Wt $17 \mathrm{~mm} \quad 34 \%$

U $14 \mathrm{~mm} \quad 29 \%$

The internal mould of iron sulfide is wholly septate. There are 26 primary ribs on the last whorl. The ribs end in a tubercle and split there into two secondary ribs that bend strongly forward on the siphonal margin. Some additional secondary ribs are in tercalated.

Discussion: The figured specimen has more primary ribs than the type of the subspecies of ArkeLt that has 22 primaries at the corresponding ontogenetic stage. The shoulders have a stronger inclination than those of the holotype of costicardia that has been refigured by ARKELL (1945, pl.69, fig. 17)

Age: Costicardia Subchron of the Cordatum Chron.

\subsubsection{Cardioceras (Cardioceras) cordatum (Sowerby 1813) \\ Pl. 2, fig. 3}

\section{Synonymy}

1986 Cardioceras cordatum (Sowrnny) - MArCHAND, p. 381, pl. 15. figs. 27,31, pl.16, figs, 8,9, pl. 17, fig.6, with synonymy

y 1989 Cardioceras (Cardioceras) cordaum (SONERBY) - FіsCHER \& Gral. Figs. $4 \mathrm{H} \cdot \mathrm{I}$

non 1991 Cardioceras (Cardioceras) cordatum (SowERBy) Schl_AMPp, pl. 34, figs 3.4

1994 Curdiocerus (Cardioceras) cordatum (SOWERIY) SCHLeGeimalch. p. 25, pl, 3, fig. 11

Material: MNHB J 23027

Locality: section RG 207, Gygl \& MARCHANd (1982, fig.2), excavation beside water conduit in Churz Tal. Siblingen $\mathrm{SH}$, bed $14 \mathrm{a}$, Glaukonitsandmergel Bed.

$\begin{array}{llll}\text { Description: Dimensions } & \text { D } & 47 \mathrm{~mm} & \\ & \text { Wh } & 19 \mathrm{~mm} & 40 \% \\ & \text { Wt } & 16 \mathrm{~mm} & 34 \% \\ & \mathrm{U} & 15 \mathrm{~mm} & 32 \%\end{array}$

The glauconitic and ferruginous carbonate internal mould is wholly septate. There are 13 primary ribs on the last whorl. These ribs end in a tuberele in the middle of the whorl sides. Two secondary ribs issue from the tubercles and bend abruptly forward on the siphonal margin, together with a third, intercalated secondary rib. The secondary ribs are attenuated to neardisappearance on the siphonal shoulders and there run almost tangentially. Where they are weakest, they bifurcate into fine tertiary ribs. The tertiaries rise in an angle of about $45^{\circ}$ towards the keel and form fine denticles where they cross the keel.

Age: Cordatum Subchron of the Cordatum Chron. 


\subsubsection{Cardioceras (Cardioceras) persecans}

(BuCKMan 1925)

Pl. 2, fig. 4

\section{Synonymy}

1986 Cardioceras cordatum (Sоwеввy), morphe tnince, variant persecans - MarchaND, p.397. pl. 15, figs. 10, 22, pl. 16, figs. 2, 3, 11 , pl.17, fig. 7, pl. 18, figs. 3, ?10, with synonymy

v 1993 Cardioceras (Cardioceras) persecans (Buckinav) - Gror \& Marchanis, pl.2. figs 2, 3,4

Matcrial: MNHB J 24982

Locality: section RG 208, GyG (1977, pl. 11, fig. 2), excavation on Brunnrain, Üken AG, bed 9, upper Schellenbrücke Bed.

$\begin{array}{llll}\text { Description: Dimensions } & \text { D } & 50 \mathrm{~mm} & \\ & \text { Wh } & 23 \mathrm{~mm} & 46 \% \\ & \text { Wt } & 15 \mathrm{~mm} & 30 \% \\ \text { U } & 14 \mathrm{~mm} & 28 \%\end{array}$

The iron oolitic, carbonate internal mould is septate to the diameter of $44 \mathrm{~mm}$. There are 26 primary ribs on the last whorl. The primaries end in a low tubercle on half the whorl height. One secondary rib may originate from a tubercle, but in most cases the secondaries are intercalated between the primary ribs. There are two and in one case three secondary ribs per primary, The secondary ribs form a tubercle on the siphonal margin. There they bend sharply forward and become weak towards the keel. Some of the secondary ribs bifurcate near the base of the kecl to form fine tertiaries. These grow stronger on the keel and form denticles where they cross it.

Age: Cordatum Subchron of the Cordatum Chron.

\subsubsection{Cardioceras (Cardioceras) cf. stella ARKELL 1947 \\ Pl. 2, fig. 5}

Synonymy

v 1982 Cardioceras (Cardioceras) ef. stello ARKEt. Gral \& MARChand, pl. 8, fig. 1

Material: MNHB J 25184

Locality: section RG 209, Grot (1977, pl.11, fig.1), Herznach iron mine. Herznach AG, bed 7. lower Schellenbrücke Bed.

$\begin{array}{llll}\text { Description: Dimensions } & \text { D } & 61 \mathrm{~mm} & \\ & \text { Wh } & 29 \mathrm{~mm} & 48 \% \\ & \text { Wt } & 21 \mathrm{~mm} & 34 \% \\ & \text { U } & 17 \mathrm{~mm} & 27 \%\end{array}$

The iron oolitic, carbonate internal mould is septate to the diameter of $46 \mathrm{~mm}$. The last whorl has 21 sharp primary ribs. These ribs end in tubercles somewhat below half the whorl height. One secondary rib continues from the tubercles and one or two additional secondary ribs are intercalated. The tubercles of the secondary ribs form the siphonal margin where the secondaries bend abruptly forward. A few secondary ribs vanish on the inclined shoulders. Most secondaries continue over the shoulders to the base of the keel where they are attenuated. Some of them split there and form tertiary ribs. The ribs crossing the keel are enhanced in denticles.

Discussion: The specimen $\mathbf{J} 25184$ cannot be assigned to Cardioceras (Cardioceras) stella Arkelt, because it is too small. It is septate only to the diameter of $46 \mathrm{~mm}$, whereas the holotype must have been septate, according to ArKelL (1946, p. 333), to a diameter of at least $125 \mathrm{~mm}$. The umbilicus of the holotype is $24 \%$ as compared with $27 \%$ of J 25184 . The specimen from Herznach is also more densely ribbed than the holotype: at a diameter of $61 \mathrm{~mm}$ it has 21 primary ribs, yet the holotype has only 16 primary ribs at the diameter $65 \mathrm{~mm}$.

Age: Cordatum Subchron of the Cordatum Chron.

Subgenus Subveriebriceras ARKELL 1941

Subgeneric type species: Cardioceras densiplicatum BODEN 1911.

\subsubsection{Cardioceras (Subvertebriceras) costellatum BUCKMAN 1925 Pl. 2, fig. 2}

\section{Synonymy}

v 1995 Cardioceras (Sidvertebriceras) costellatum BUCKMAN - GyGt, p. 19, fig, $3 / 3$, with synonymy

Material: MNHB J 31648

Locality: Bollement, St-Brais JU, Renggeri Member.

$\begin{array}{llll}\text { Description: Dimensions } & \text { D } & 35 \mathrm{~mm} & \\ & \text { Wh } & 15 \mathrm{~mm} & 43 \% \\ & \text { Wt } & 13 \mathrm{~mm} & 37 \% \\ & \text { U } & 10 \mathrm{~mm} & 29 \%\end{array}$

The internal mould of iron sulfide is wholly septate. 32 primary ribs have been counted on the last whorl. Some of the primary ribs end in an elongated. low tubercle in the middle of the whorl sides. There they split up into two secondary ribs. Some of the primaries are undivided. The ribs are enhanced on the siphonal margin and then are attenuated on the shoulders. They grow stronger again on the keel where they form denticles.

Age: Costicardia Subchron of the Cordatum Chron. 


\subsubsection{Cardioceras (Subvertebriceras) densiplicatum BODEN 1911 \\ Pl. 2, fig. 7}

\section{Synonymy}

1911 Cardioceras vertebrale SOW. sp. var. densiplicara nov. var. BODEN, p. 159 , pl. 1. fig. 14

1942 Cardioceras (Subvertebriceras) densiplicufum BODEN ARkEL., p. 240 , pl. 52, figs. $3-5$, pl. 53 , figs. 1. 4. 7-12, with synonymy

1977 Cardiaccras (Subvertebriceras) densiplicatum Bodes BOURSEAU, p. 92, pl.8, figs, 5, 10, with synoymy

1979 Cardioceras (Subvertebriceras) densiplicatum BODEN - SYKEs \& Culomon, pl. 112, fig. 4

v 1982 Cardioceras (Vertebricenas) densiplicattum BODEN - GyGl \& Marchand, pl. 11, fige 5-6

1984 Cardinceras (Stibveriebriceras) densiplicatum BODEN TARкowski, pl. 11, figs $1.6,7$, pl. 12, fig. 6

$\checkmark 1989$ Cardioceras (Vertebriceras) densiplicatum Bones - Fiscuer \& GyGi, figs 4 B-C

1994 Cardinceras (Subvertebriceras) densiplicatum BoDex SCHLEgelMtLCH, p. 27, pl. 5, fig. 1

Material: MNHB J 23045

Locality: section RG 212, GYG1 (1977. pl.11, fig. 7), excavation above the shooting range in Churz Tal, Siblingen $\mathrm{SH}$, bed 7. Mumienmergel Bed.

$\begin{array}{llll}\text { Description: Dimensions } & \text { D } & 46 \mathrm{~mm} & \\ & \text { Wh } & 20 \mathrm{~mm} & 43 \% \\ & \text { Wt } & 19 \mathrm{~mm} & 41 \% \\ & \text { U } & 13 \mathrm{~mm} & 28 \%\end{array}$

The glauconitic, carbonate internal mould is wholly septate. There are 20 primary ribs on the last whorl. The ribs end in a high tubercle at half the whorl height. Two and occasionally three secondary ribs may be counted per primary rib. The secondary ribs form tubercles at the siphonal margin. Some of the secondaries split on the almost horizontal shoulders and form fine tertiary ribs. The strong keel is denticulated.

Age: Densiplicatum Subchron of the Transversarium Chron.

\section{Subgenus Maltoniceras ARKELL. 194]}

Subgeneric type species: Ammonites mallonensis Young \& BIRD 1822

\section{4,1.21 Cardioceras (Maltoniceras) schellwieni BODEN 1911 \\ Pl. 2, fig. 12}

\section{Synonymy}

1911 Cardioceras Schellwieni nov. sp. - BODEN, p. 158, pl. 2, fig, 3

1941 Cardioceras (Malroniceras) schellwieni BODEN - ARKEL.L. p. 234, pl.51, fig. 11

v 1982 Cardioceras (Malinniceras) schellwieni BoDEv - Gral \& MaRCHAND, pl. 13, figs, 3,6,7

1994 Cardioceras (Maltoniceras?) schellwieni BoDEx SCHLEGLMiLCH, p. 28, pl.6, fig.1
Material: MNHB J 23029

Locality: section RG 207. GYGI \& MARCHAND (1982, fig. 2), excavation beside water conduit in Churz Tal, Siblingen SH, bed 16a, lower Mumienkalk Bed.

$\begin{array}{llll}\text { Description: Dimensions } & \text { D } & 85 \mathrm{~mm} & \\ \text { Wh } & 37 \mathrm{~mm} & 44 \% \\ \text { Wt } & 27 \mathrm{~mm} & 32 \% \\ \text { U } & 22 \mathrm{~mm} & 26 \%\end{array}$

The glauconitic, carbonate internal mould with parts of the shell is septate to the diameter of $58 \mathrm{~mm}$. More than half of the last whorl is occupied by the body chamber. The specimen appears to be a nearly complete adult. The inner whorls have been well described by BoDEN (1911, p. 158). On the last whorl of specimen J 23029, at the end of the phragmocone, there are 9 widely-spaced primary ribs. The ribs are straight and radial. They end in a tubercle at half the whorl height. There are two secondaries per primary rib. One secondary begins near a median tubercle, whereas the second is intercalated. The secondary ribs form a tubercle on the siphonal margin. The keel is high and finely denticulated. There are three to four denticles per sccondary rib. No tertiary ribs are visible on the inclined shoulders. The ribbing fades away almost completely on the body chamber.

Age: Antecedens Subchron of the Transversarium Chron.

Subgenus Miticardioceras BUCKMAN 1923

Subgeneric type species: Miticardioceras mite BuckMaN 1923. pl. 375 .

\subsubsection{Cardioceras (Miticardioceras) tenuiserratum (OPPEL 1863) \\ Pl. 2, fig. 10}

\section{Synonymy}

1986 Cardioceras temuiserratum (OPFEL) - MARCHAND, p. 425.pl. 22. figs. $11-12$, with synonymy

1991 Cardioceras (Miticardioceras) temuiserratun (OPPEL) SCHLAMPr, p. 95 , pl. 34, fig. 8

1994 Cardioceres (Cawmenicras) tentiserratun (OPFEL) Sehlegetmichi, p. 27, pl.5, fig. 3

Material: MNHB J 25158

Locality: section RG 208, Gral (1977, pl. 11. fig, 2), excavation on Brunnrain, Üken AG, bed 12 or higher up, lower Birmenstorf Member.

$\begin{array}{llrl}\text { Description: Dimensions } & \text { D } & 24 \mathrm{~mm} & \\ & \text { Wh } & 10 \mathrm{~mm} & 42 \% \\ \text { Wt } & 7 \mathrm{~mm} & 29 \% \\ \text { U } & 7 \mathrm{~mm} & 29 \%\end{array}$


The carbonate internal mould is scptate to the diameter of $16 \mathrm{~mm}$. The last two septa are approximated and indicate that the specimen is adult. The body chamber oceupies two thirds of the last whorl. The first primary ribs appear at the diameter of $6 \mathrm{~mm}$. They begin on the rounded umbilical margin and are radial. The ribs end in a low tubercle in the middle of the whor sides. There are 12 primary ribs per whorl at the diameter of $19 \mathrm{~mm}$. The secondary ribs are reduced to small tubercles on the siphonal margin. Two such tubercles can be counted per primary rib. The strongly inclined shoulders are smooth. The finely denticulated keel is low. There are four denticles per secondary tubercle. The ornamentation fades towards the end of the body chamber.

Age: Late Antecedens to early Luciaeformis Subchron of the Transversarium Chron.

\section{Genus Amoeboceras HyatT 1900}

Type species: Ammonites alternans von BUCH 1832

\subsubsection{Amoeboceras glosense}

(BIGOT \& BRASIL 1904)

$$
\text { Pl.5, fig. } 3
$$

\section{Synonymy}

1904 Candiocems altemans var glosensis - Bigor \& BRAsiL, p. 17. pl.1. fig. 17

1916 Cardioceras alternoides (NIkITIN) - NikITIN, p. 6, pl. 1, fig. 1

1976 Ameebocemas glosense (Bigut a Brasil) - Srkes \& Strirk, fig. $5 \mathrm{D}$

1979 Anoeboceras glosense (Bugot \& BRASHL) - SYKES \& CALlomov, p. 872, pl. 113, fige 5-7.9. pl. 115, figs, 1,9. pl. 116. figs, $1-3,6-9$

v 1993 Amochocenas glosense (Brour \& Brasic) - Atgops et al.,pl,1, figs. $2-4$

Material: MNHB J 27679 .

Locality: section RG 276, Grgl et al. (1979, fig. 3), Chalch quarry. Holderbank AG, probably bed 32, Birmenstorf Member.

Description: Dimensions D $50 \mathrm{~mm}$

Wh $21 \mathrm{~mm} \quad 42 \%$

Wt $15 \mathrm{~mm} \quad 30 \%$

U $16 \mathrm{~mm} \quad 32 \%$

The carbonate internal mould is septate to the diameter of $39 \mathrm{~mm}$. One fourth of the last whorl is occupied by the body chamber, 25 primary ribs can be counted on the last whorl. They are radial and straight on the phragmocone. Many of them are undivided. On the body chamber the ribbing is modified: the primary ribs end in a tubercle slightly above half the whorl height. There they split up into two secondary ribs. The secondaries are enhanced at the siphonal margin and continue to near the base of the keel where they vanish. The sharp keel is well-preserved only on the phragmocone. It has few and indistinct denticles.
Discussion: The holotype of $A$ mocboceras glosense as refigured by SYKes \& CALLOMON (1979, pl 155, fig. 9) has a diameter of $86 \mathrm{~mm}$ and is wholly septate. The specimen MNHB J 27679 from Holderbank is septate to a diameter of only $39 \mathrm{~mm}$ and is therefore much smaller. The modified ribbing on the body chamber of $J 27679$ suggests that the specimen cannot be assigned without doubt to the taxon glosense. However, Sykes \& CaLlomon (1979) assume a certain variability within this taxon: in the specimens 5 and 6 of their pl.113 there are apparently weak tubercles on the whorl sides. The specimen J 27679 from Holderbank is therefore assigned with reservation to Amoeboceras glosense.

Age: Late Luciaeformis Subchron of the Transwersarium Chron.

\subsubsection{Amoeboceras ef. serratum (SowERBY 1813)} Pl. 8, fig. 4

Synonymy

v 1993 Amoeloccras serratum (SowERBY)-Amodboceras ovale (QUENSTEI) intermediate form-ATrops et al, pl. 1, fig. 6

Material: MNHB J 31456

Locality: Quarry $500 \mathrm{~m}$ north of Mönthal $\mathrm{AG}$, Gerstenhübel Beds, Effingen Member.

Description: Dimensions

$\begin{array}{lll}\mathrm{D} & 18.4 \mathrm{~mm} & \\ \mathrm{Wh} & 7.8 \mathrm{~mm} & 42 \% \\ \mathrm{Wt} & - & - \\ \mathrm{U} & 5.0 \mathrm{~mm} & 27 \%\end{array}$

This tiny specimen is only an imprint in lime mudstone. There are 30 primary ribs on the last whorl. They begin on the rounded umbilical wall and swing slightly back until the umbilical margin. Then they bend somewhat forward. In the middle of the whorl sides they swing very little back again and end at the siphonal margin in an elongate tubercle. Short secondary ribs are intercalated between the majority of the primaries. There is a prominent keel with smooth sides and regular, fine denticles.

Discussion: The ribbing of $\mathbf{J} 31456$ compares well with the inner whorls of the neotype of Amoeboceras serratum (SOWERBY) as figured by SYKES \& CALLOMON (1979, pl. 117, fig. 1c). The neotype has somewhat more primary ribs. It is so much larger than the specimen from Monthal that $\mathrm{J} 31456$ cannot be assigned to A. serratum. ATrops et al. (1993, pl. 1, fig .6) classified the specimen from Mönthal as an intermediate form between Amoeboceras serranum (J. SowERBY) and Amoeboceras ovule (QUEN. STEDT).

Age: It is difficult to cstablish the age of the Gerstenhubel Beds for lack of diagnostic ammonites. According to the mineralostratigraphic correlations by GYGi \& PERSOz (1986, pl. 1), this prominent limestone unit is somewhat younger than the latest 
Perisphinctes (Dichotomoceras) bifurcanus (QUenstedT) and considerably older than Euaspidoceras hypseium (OPPEL). The age of Amoeboceras cf. serratum J 31456 is therefore probably the late Bifurcatus Chron.

\subsubsection{Amoeboceras ovale (Quenstedt 1849) \\ Pl. 10, fig.2}

\section{Synonymy}

1915 Cardioceras avale QueNSIEDI. emend SALFELD - SALFELD. p. $166, \mathrm{pl} .16$, figs $1-2,5,8-10$, with synonymy

1988 Amoeboceres ovale (QUINSTEDT) - MATIAA \& WIERBZBOWSKI. pl. 1

v 1993 Amoeboceras ovale (Ouenstemt) - Atrofs er al.pl. 1, fig. 9

1994 Amoeboceras ovale (OUENSIEDT) - MaTYA \& WIERZBOWSKI. pl. 1, figs, 4-7, $11-12$

1994 Amoeboceras (Amoeboceras) ovale (QUENSTEDT) Schlegelmilch. p. 30. pl. 7, fig. 3

Material: MNHB J 25608

Locality: section RG 70, Grgi (1969, pl. 17). large quarry. Mellikon AG, bed 6, lower Crenularis Member.

Description: Dimensions D $35 \mathrm{~mm}$

$\begin{array}{lll}\mathrm{Wh} & 13 \mathrm{~mm} & 37 \% \\ \mathrm{Wt} & - & - \\ \mathrm{U} & 11 \mathrm{~mm} & 31 \%\end{array}$

The carbonate internal mould is septate to the diameter of $20 \mathrm{~mm}$. Three quarters of the last whorl are occupied by the body chamber. There are 33 primary ribs on the last whorl. The ribs begin on the rounded umbilical wall and first swing strongly backward. On the internal part of the whorl sides the primary ribs lean forward. In the middle of the whorl sides they bend again slightly backward. The primary ribs end on the body chamber somewhat above half the whorl height. Secondary ribs appear in their place that are intercalated between the primaries. There are 19 primary ribs and 24 secondaries on the last half whorl. The high and narrow keel has smooth walls and fine, sharp denticles.

Age: Grossouvrei Subchron of the Bifurcatus Chron to the Hypselum Subchron of the Bimammatum Chron.

\subsubsection{Amoeboceras tuberculatoalternans (NikITIN 1878) \\ Pl. 10, fig. 3}

Synonymy

1915 Cardioceras iuberculato-allemans NIKITIN - SuIJUD. p. 162. pl. 17, fig 4 , with synonymy

v 1993 Amoeboceras tuberculatoalternans (NıкІтІ ) - Aтrors et al. pl. 1, fig. 14

Material: MNHB J 31462
Locality: section RG 76, Gyar (1969. fig. 2). Hornbuck, Erzingen D. bed 11. Hornbuck Member.

\begin{tabular}{|c|c|c|}
\hline Description: Dimensions & & $18 \mathrm{~mm}$ \\
\hline & $\mathrm{Wh}$ & $8 \mathrm{~mm}$ \\
\hline & Wt & $7 \mathrm{~mm}$ \\
\hline & $\mathrm{U}$ & $5 \mathrm{~mm}$ \\
\hline
\end{tabular}

The carbonate internal mould is septate to the diameter of $11 \mathrm{~mm}$. The last two septa are approximated and indicate that this small specimen is adult. The primary ribs begin at the rounded umbilical margin and lean slightly forward. In the middle of the whorl sides they become radial and form a distinct tubercle. Beyond this tubercle the primary ribs are strongly attenuated. They are again enhanced forming a tubercle at the siphuncular margin. There the ribs turn sharply forward and vanish completcly on the shoulders which are horizontal in cross-section. The secondary ribs are intercalated at irregular intervals. The keel is low and has smooth sides. It bears sharp denticles.

Age: Bimammatum Subchron of the Bimammatum Chron.

Superfamily Perisphinctaceae STEINMANN 1890

Family Perisphinctidae Sternmann 1890

Subfamily Perisphinctinae SteInMAnN 1890

Genus Perisphinctes WaAgen 1869

Type species: Ammonites variocostaltus BUCKLAND 1836

Subgenus Neomorphoceras ARKELL 1953

Subgeneric type species: Ammonites Chapuisi OPPEL 1857

\subsubsection{Perisphinctes (Neomorphoceras) chapuisi (OPPEL 1857) \\ Pl. 8, fig. 6}

Synonymy

1966 Perisphinctes (Neomorphoceras) chapuasi (OPPEL) - ENay, p. 443, with synonymy

1994 Neomorphoceres chapuisi (OppeL) - SchLEgelмiLch, p.62. pl.21. fig 4

Material: MNHB J 26129

Locality: section RG 207. Gygt \& MARCHAND (1982, fig. 2), excavation beside water conduit in Churz Tal, Siblingen $\mathrm{SH}$, bed 16b, upper Mumienkalk Bed.

$\begin{array}{llrl}\text { Description: Dimensions } & \text { D } & 18 \mathrm{~mm} & \\ & \text { Wh } & 5 \mathrm{~mm} & 28 \% \\ & \text { Wt } & 5 \mathrm{~mm} & 28 \% \\ \text { U } & 8 \mathrm{~mm} & 44 \%\end{array}$

The glauconitic, carbonate internal mould is septate to the diameter of $12 \mathrm{~mm}$. The last two septa are somewhat approximated. The body chamber is complete to the peristome and oc- 
cupies two thirds of the last whorl. There is a conspicuous constriction before the peristome. A siphuncular furrow is visible on the last quarter whorl of the phragmocone. On the last half whorl of the phragmocone there are distinct, straight primary ribs that are slightly prorsiradiate (inclined forward). They split into two secondary ribs at two thirds the whorl height. The seeondaries are interrupted at the siphonal furrow. The umbilicus of the inner whorls is narrow, but it rapidly increases on the last half whorl of the phragmocone. The last whorl covers the preceding one only slightly. The whorl thickness cven decreases a little from the end of the phragmocone to the aperture.

Age: late Antecedens Subchron to Luciaeformis Subchron of the Transversarium Chron.

\subsubsection{Perisphinctes (Neomorphoceras) collinii (Oppel 1863) Pl. 8. fig. 7}

Synonymy

1966 Perisphincles (Neomorphoceras) collinü (OPPEL) - ENAY, p. 444. with synonymy

1991 Neomorphoceras collinii (Oppes) - Schlamp, pl. 1, figs. 1-2

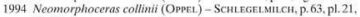
fig. 10

Material: MNHB J 24170

Locality: section RG 230, GyGl (1977, pl. 11, fig -3), excavation north of Eisengraben, Gansingen AG, upper Birmenstorf Member.

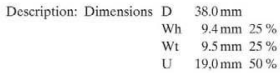

The carbonate internal mould is septate to the diameter of $22 \mathrm{~mm}$. The body chamber occupies almost the en tire last whorl. It ends at a constriction near the aperture, but the peristome itself is not preserved. At the end of the phragmocone there is a faint siphonal furrow. The delicate primary ribs are straight and radial. Somewhat above half the whorl height they split into two secondary ribs that continue in the same direction. The secondaries are attenuated along a narrow siphonal band. The innermost whorl has a narrow umbilicus, but on the last whorl of the phragmocone the umbilicus becomes disproportionately wider. The thickness of the last whorl does not vary.

Age: Luciaeformis Subchron of the Transversarium Chron.
Subgenus Otosphinctes Buckman 1926

Subgeneric type species: Otosphinctes ouatius BuCKMAN 1926

\subsubsection{Perisphinctes (Otosphinctes) paturattensis DE LORIOL 1901 \\ Pl. 2, fig. 6}

Synonymy

1989 Perisphinctes (Olosphinctes) paturattensis DE LORIOL - MELENDEZ, p. 270, pl. 36, figs. 2-7, with synonymy

Material: MNHB J 23277

Locality: section RG 208, Gral (1977, pl.11, fig. 2), excavation on Brunnrain, Üken AG, bed 9, upper Schellenbrucke Bed.

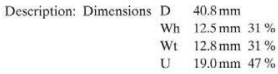

The iron oolitic, carbonate internal mould is septate to the diameter of $27 \mathrm{~mm}$. The last two septa are approximated. Two thirds of the last whorl are occupied by the body chamber. The specimen is a complete adult with the peristome and on one side with part of a lappet. The primary ribs are straight and radial. They begin at the umbilical suture line and bifurcate at about two thirds the whorl height. The secondary ribs are faint. They have the same direction as the primaries and are not attenuated at the siphonal side. There are deep and narrow constrictions every half or two thirds a whorl. The last constriction is directly before the peristome. A pair of parabolic nodes is on the body chamber at the diameter of $34 \mathrm{~mm}$. The inner whorls have a depressed section.

Age: Cordatum Subchron of the Cordatum Chron.

\subsubsection{Perisphinctes (Otosphinctes) siemiradzkii ENAY 1966 \\ P1. 8, fig. 1 - text-fig. 41}

Synonymy

1966 Perisphinetes (Olosphinctes) siemiradzkii n.sp.-ENax. p.458, pl. 26. figs: $1-3$

1982 Perisphinctes (Orosphinctes) sierniradzkii ENAY - DEBRANDPas5ard,pl. 14, fig. 4

v 1989 Perisphincies (Olosphinctes) sieniradzkii ENAY - FIschen \& Groi, fig 6 B

\section{Material: MNHB J 23656}

Locality: section RG 230, Gyor (1977, pl. 11, fig, 3), excavation north of Eisengraben, Gansingen AG, upper Birmenstorf Member. 
Description: Dimensions D $102 \mathrm{~mm}$

$\begin{array}{lll}\text { Wh } & 28 \mathrm{~mm} & 27 \% \\ \mathrm{Wt} & - & - \\ \mathrm{U} & 52 \mathrm{~mm} & 51 \%\end{array}$

The carbonate internal mould is septate to the diameter of $69 \mathrm{~mm}$. The body chamber occupies seven eights of the last whorl. It is probably complete, because the two last ribs arc approximated and lean abnormally forward. The maximum diameter of the specimen must have been $112 \mathrm{~mm}$. The primary ribs are sharp and straight. They begin at the umbilical suture line and are inclined $9-14^{\circ}$ forward. Many of them are undivided, but most split into two secondary ribs at two thirds the whorl height. The secondary ribs are not attenuated on the siphonal side. They have the same direction as the primary ribs. The section of the inner whorls is almost circular, but slightly depressed. At the end of the body chamber the whorl height approaches the whorl thickness. The rib curve of the specimen from Gansingen (text-fig.41) closely resembles the curve of the holotype in ENAY (1966, fig, 131).

Age: Luciaeformis Subchron of the Transversarium Chron.

\section{Subgenus Arisphinctes BucKMaN 1924}

Subgeneric type species: Arisphinctes ariprepes BuckMaN 1925

\subsubsection{Perisphinctes (Arisphinctes) plicatilis} (SOWERBY 1817)

PL. 3, fig. 1 - text-fig. 42

Synonymy

v 1966 Perisphinctes (Arisphinctes) plicatilis (SowerBX) ENAY, p. 416. pl 19. fig. 2, with synonymy

v 1972a Perisphinctes (Arisphinctes) plicatilis (SOWERBY) Maunowska, p. 184, text-fig. 8, pl. 4, figs, 1-2

$\mathrm{v}$ non $1972 \mathrm{~b}$ Perisphinctes (Arisphinctes) plicarilis (Sow E rav) Malinowsika, p. 18, pl.5, fig. 1

1973 Perisphinctes (Arisphinctes) plicatilis (SOWERBy) SAPUNON, p. 111, pl.2, fig. 4

non 1974 Perisphinctes (Arisphinctes) plicalilis (SowERBY) SEqueiros, p. 160, pl.17, fig.2, pl.18, fig.2

1979 Perisphinctes (Arisphincies) plicatilis (SoWrerv) SAPUNON, p. 76, pl. 17. fig. 3

?1984 Perisphinctes (Arisphinctes) plicatilis (SowERHY) MFleNdez, p. 445, pl 23, fig. 2

non 1984 Perisphinctes (Arisphinctes) plicatilis (SowErgy) Melendez,pl.23, fig. 1

v 1989 Perisphincles (Arisphincles) plicutilis (SowERBY) Fischer \& Gras. lig. 4 D

71989 Perisphinctes (Arisphinctes) plicatilis (Sonwerky) Metendiz, p.229,pl.23, fig.2

non 1989 Perisphincles (Arisphinctes) plicatilis (Sowerny) Melendez, pl.23, fig. 1

1994 Perisphincles (Kranaosphincles) plicatilis (SOWER日y) -

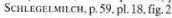

\section{Material: MNHB J 24633}

Locality: section RG 81b, GYGI (1977, pl. 11, fig.6), excavation
Ribs per whorl

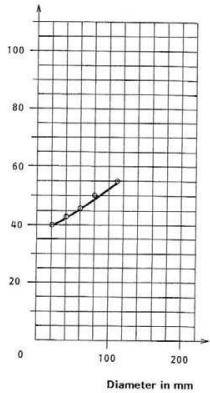

Fig. 41: Rib curve of Perisphinctes (Olosphinctes) siemiradzkit ENAy MNHB . 23656.

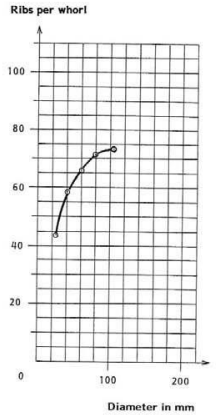

Fig. 42: Rib curve of Perisphinctes (Arisphincies) plicarilis (Sowrzay) MNHB J 24633. 
below Räckolterenbuck, Gächlingen $\mathrm{SH}$, bed 13, Mumienmergel Bed.

\begin{tabular}{|c|c|c|}
\hline Description: Dimensions & $\mathrm{D}$ & $105 \mathrm{~mm}$ \\
\hline & $\mathrm{Wh}$ & $35 \mathrm{~mm}$ \\
\hline & Wt & $29 \mathrm{~mm}$ \\
\hline & $\mathrm{U}$ & $44 \mathrm{~mm}$ \\
\hline
\end{tabular}

The glauconitic, carbonate internal mould is wholly septate. The primary ribs are fine, low and blunt. They begin at the umbilical margin. The ribs are straight on the flat, convergent whorl sides and lean about $8^{\circ}$ forward. They split on the siphonal margin into two. feeble secondary ribs. Unsplit primaries are not uncommon. The secondary ribs continue in the same direction as the primaries. They almost vanish along a narrow siphonal band. The siphonal side is rounded.

Age: Densiplicatum or early Antecedens Subchron of the Transversarium Chron.

\subsubsection{Perisphinctes (Arisphinctes) helenae DE RIAZ 1898}

Pl. 3,fig. 2-text-fig. 43

Synonymy

y 1989 Perisphinctes (Arisphinctes) helenae DE RIAZ - FISCHER \& GYGi. Fig. 5 A

? 1989 Perisphincies (Arisphincies) helende DE RIAZ - MEIENDEZ, p. 233, pl. 24, fig, 1 , with svnonymy

\section{Material: MNHB I 24575}

Locality: section RG 81b. GyGt (1977, pl. 11, fig.6), excavation below Räckolterenbuck, Gächlingen $\mathrm{SH}$, bed 14a, lower Mumienkalk Bed.

$\begin{array}{llll}\text { Description: Dimensions } & \text { D } & 92 \mathrm{~mm} & \\ \text { Wh } & 27 \mathrm{~mm} & 29 \% \\ \text { Wt } & 20 \mathrm{~mm} & 22 \% \\ \text { U } & 46 \mathrm{~mm} & 50 \%\end{array}$

The glauconitic, carbonate internal mould is wholly septate. The section of the last whorl is trapezoidal with flat, slightly convergent whorl sides. There is a pronounced siphonal margin, and the siphonal side is only moderately rounded. The primary ribs are straight, low, but sharp. They lean about $10^{\circ}$ forward. The primaries begin on the inner whorls at the umbilical suture line. but on the last whorl there is a smooth band at the base of the rounded umbilical wall. The primary ribs are somewhat drawn backward on the umbilical wall. A few of them are simple. Most of them split into two secondary ribs that have a stronger forward inclination than the primaries. The point of bifurcation is high on the whorl sides, at $83 \%$ of the whorl height. The secondary ribs are strong. They are not attenuated at the siphonal side where they form a forward leaning arc.

Age: Antecedens Subchron of the Transversarium Chron.
Subgenus Dichoomosphinctes Buckmax 1926

Subgeneric type species: Perisphinctes $\mathrm{cf}$. Wartae BUkowskı mutatio aniecedens SALFELD 1914.

\subsubsection{Perisphinctes (Dichotomosphinctes) antecedens SALFELD 1914 \\ Pl. 3, fig. 4 - text-fig, 44}

Synonymy

1982 Perisphincres (Dichotomosphinctes) antecedens SALFLD Debrand-Passard.pl.13, fig. 2

1989 Perisphinctes (Dicholomosphinctes) antecedens SALFELD MEt.ENDE2, p. 292, pl.41, figs. 1-3, with synonymy

$v 1989$ Perisphincres (Dichotomosphincres) anrecedens SALFELD Fischer \& Gral, fig, 5 D

\section{Material: MNHB J 24701}

Locality: section RG 207. GyGi \& MARCHAND (1982, fig. 2), excavation beside water conduit in Churz Tal, Siblingen SH, lower Mumienkalk Bed 16 a.

$\begin{array}{llrl}\text { Description: Dimensions } & \text { D } & 120.0 \mathrm{~mm} & \\ \text { Wh } & 32.0 \mathrm{~mm} & 27 \% \\ \text { Wt } & 32.5 \mathrm{~mm} & 27 \% \\ \text { U } & 62.0 \mathrm{~mm} & 52 \%\end{array}$

The glauconitic, carbonate internal mould is septate to the diameter of $107 \mathrm{~mm}$. The body chamber forms one fourth of the

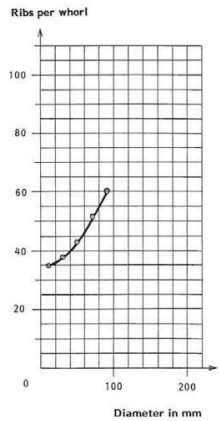

Fig. 43: Rib eurve of Perispinctes (Arisphincles) helence DE RIAZ. MNHB 324575 . 
last whorl. The strong primary ribs are straight and sharp. They begin on the umbilical wall and bifurcate regularly at $80 \%$ of the whorl height. They have a mean inclination of $9^{\circ}$ forward. The secondary ribs are strong. They bend a little more forward than the primaries and form a forward leaning arc at the siphonal side. There are deep constrictions. The whorl sides are slightly convex and convergent. The siphonal side is rounded.

Age: Antecedens Subchron of the Transversarium Chron.

\subsubsection{Perisphinctes (Dichotomosphinctes) elisabethae DE RIAZ 1898 \\ Pl. 3, fig. 5-text-fig. 45}

\section{Synonymy}

1966 Parisphinctes (Dichotomosphinctes) elisabethae DE RIAZ Evar, p. 490, pl. 30, figs, 4, 5, pl. 31, figs. $2-6$, with synonymy non 1977 Perisphinctes (Arisphinctes) elisaberhae (DE RIaz) ZiEGLER, pl. 1, fig 1

1980 Perisphinctes (Dichoromosphinctes) elsabethae DE RIAZBROCHWICZ-LEWINSKi, p. 210, pl.1, fig 1

1981 Perisphinctes (Dicholomasphinctes) elisubethae DE R1Az Enay a Boullitr, pl. 2, fig. 3

non 1987. Perisphincters (Arisphincles) elisabcthae (It RiA2) ZIEGLER, pl. 1. Fig. 4

v 1989 Perisphincles (Dichotomosplincies) etisabethae DE RLAZ. Fischer \& Grol, fig. 5 E

mon 1994 Perisphmetes (Krancosphinctes) eliseberhat DF RIsz SCHLEGELMILCH, p. 60. pl. 18 , fig. 3

\section{Material: MNHB J 24528}

Locality: section RG 816, GYG (1977. pl. 11, fig 6), excavation below Räckolterenbuck, Gächlingen SH, bed $14 \mathrm{a}$. lower Mumienkalk Bed.

Description: Dimensions D $77 \mathrm{~mm}$

Wh $24 \mathrm{~mm} 31 \%$

Wt $21 \mathrm{~mm} \quad 27 \%$

U $\quad 34 \mathrm{~mm} \quad 44 \%$

The glauconitic, carbonate internal mould is septate to the diameter of $80 \mathrm{~mm}$. One eighth of the last whorl is occupied by the oody chamber. The fine, but sharp primary ribs are slightly proconvex. On the inner whorls they begin at the umbilical suture ine. On the last whorl the base of the umbilical wall is smooth. There the primary ribs begin on the rounded umbilical margin where they first swing somewhat backward. On the whorl sides he ribs have a mean forward inclination of $11^{\circ}$. Some of them are imple, but most of them split on the siphonal margin into two econdary ribs. The secondaries have a stronger forward inclinafon than the primary ribs and form a proconvex are at the iphonal side. They may locally be attenuated at a shallow iphonal furrow on the phragmocone. The point of bifurcation is $180 \%$ of the whorl height. The whort sides are flat and slightly onvergent. The siphonal side is rounded except where there is a arrow. Two shallow constrictions are visible on the last two horls.

ge: late Antecedens Subchron of the Transversarium Chron.

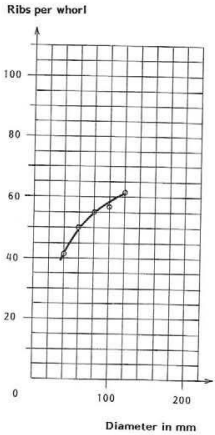

Fig 44: Rib curve of Perisphinctes (Dichoromosphinctes) antecedents SALFEID MNHB J 24701.

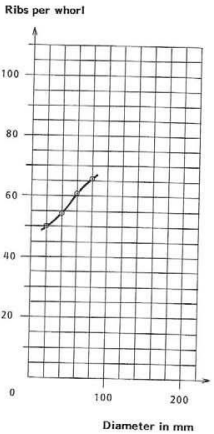

Fig.45: Rib curve of Perisphinctes (Dichotomosphinctes) elisabethae DE Rinz MNHB J 24528 . 


\subsubsection{Perisphinctes (Dichotomosphinctes) luciaeformis ENAY 1966 \\ Pl. 5, fig. 4-text-fig. 46}

\section{Synonymy}

1966 Perisphincles (Dichotonosphinctes) luciaeformis n.sp. - ENAY. p. 496 , pl. 32, figs. $1-3$

1984 Perisphinctes (Dicholomosphincres) huciacformis ENAY Melendez p. 602 . pl. 45, figs, 1-2, pl. 46, figs. 1-4,? pl. 47 , figs. $2-4$

1989 Perisphinctes (Dichotomosphinctes) luciasformis Evar - MEIFNDEZ. p. 301 , pl . 45, figs. 1-2, pl. 46, figs. 1-4, ? pl. 47 , figs. $2-4$

v 1989 Perisphinctes (Dichotomosphinctes) luciaeformis ENAY - FisCHER \& Gvat, fig. 6 D

1990 Perispininctes (Dichotomosphinctes) Luciaeformis Evar FONTANA, p. 75 , pl. 2, figs $1-4$

Material: MNHB J 23652

Locality: section RG 212, GrGi (1977, pl.11, fig. 7), excavation above the shooting range in Churz Tal, Siblingen $\mathrm{SH}$, bed 10 , glauconitic bed of the lowermost Effingen Member.

Description: Dimensions D $117 \mathrm{~mm}$

$\begin{array}{lll}\text { Wh } & 36 \mathrm{~mm} & 31 \% \\ \text { Wt } & 28 \mathrm{~mm} & 24 \% \\ \mathrm{U} & 55 \mathrm{~mm} & 47 \%\end{array}$

The glauconitic, carbonate internal mould is septate to the diameter of $77 \mathrm{~mm}$. The body chamber occupies two thirds of the last whorl. The primary ribs are low, but sharp. They begin on the lower part of the rounded umbilical wall and are straight or almost imperceptibly proconcave. On the last whorl there are eleven unsplit primary ribs. They lean $8^{\circ}$ forward. Most of the primaries split at about $72 \%$ of the whorl height into two secondary ribs. The secondaries have a slightly greater forward inclination than the primary ribs. They form a proconvex arc on the siphonal side. At the end of the phragmocone and at the beginning of the body chamber there is a narrow and shallow siphonal furrow that is not deep enough to interrupt the secondary ribs. The last whorl covers the preceding one by only $16 \%$. The sides of the last whorl are slightly convex and converge very little. The siphonal side is rounded. The constrictions are narrow and not decp. They are commonest on the innermost whorls.

Agc: Luciaeformis Subchron of the Transversarium Chron.

Subgenus Dichotomoceras Buckmar 1919

Subgeneric type species: Dicholomoceras dichotomum. BuckMAN 1919

\subsubsection{Perisphinctes (Dichotomoceras) rotoides RONCHADZE 1917 \\ Pl. 9, fig. 1 - text-fig. 47}

\section{Synonymy}

v 1917 Perisphinctes roloides n. sp- - RonchaD2E, p. 11. pl.1, fig, 8

\section{Ribs per whorl}

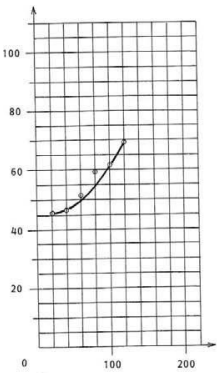

Diameter in $\mathrm{mm}$

Fig. 46: Rib curve of Perisphinctes (Dichotomosphinctes) luciatormis ENAY MNHB J 23652 .

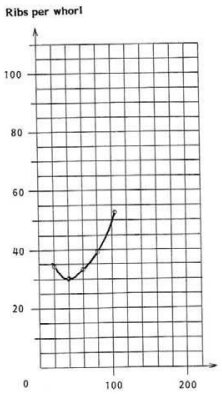

Diameter in $\mathrm{mm}$

Fig. 47: Rib curve of Perisphinctes (Dichotomoceras) rotoides RoN CHADZE MNHB I 27971. 
uon 1937 Perisplünctes (Dichotamosphinctes) rotoides RoNCHADZE - AnKEL.1. p. 90, pl. 16, figs. 1-7

non 1952 Perisphinctes (Dichotomosphinctes) rotoides RoNChaDZE - Siegfried, p. 309, pl.F, fig. 2

1959 Dichoiomosphinctes rotoides RonchaDzE - CoLLignov, pl.64, fic. 287

pars 1966 Perispininctes (Dichotomosphinctes) rototdes RoNCHADZH - Evar,p. 467, figs. 138/1-2.pl.27. figx.9.11, non fig. 10

non 1975b Perisphinctes (Dichotomosphinctes) rotoides RonChadze - BROCHWICZ-LEWINSKI. pl. 3, lig. 2

non 1976 Perisphinctes (Dichotomosphincles) rotoides RoNCHADZF - SAPUNov, pl. 2, fig. 1

non 1977 Perisphinctes (Dichotomosphincles) rotoides RONCHALZE - Bourseal, p.31, pl. 1, fig. 6, pl. 4, figs 3,8

non 1979 Perisphincies (Dichoromosphincies) motodes RonchaDze - Sipunov, p. 82. pl.19. fig. 1

non 1984 Perisphinctes (Dichotomosphincles) rotoides RONCHADZI - TARKowski,pl. 14, fig. 6

Material: MNHB J 27971

Locality: section RG 276, Gygt et al. (1979, fig. 3), Chalch quarry, Holderbank AG, bed 46. Jower Effingen Member.

\begin{tabular}{|c|c|c|c|}
\hline Description: Dimensions & & $104 \mathrm{~mm}$ & \\
\hline & Wh & $32 \mathrm{~mm}$ & 31 \\
\hline & Wt & - & - \\
\hline & $\mathrm{U}$ & $49 \mathrm{~mm}$ & 47 \\
\hline
\end{tabular}

The carbonate internal mould is septate to the diameter of ca $68 \mathrm{~mm}$. The exact figure cannot be established, because the inncr whorls are compressed in the plane of the spiral axis. Three quarters of the last whorl are occupied by the body chamber. The primary ribs are strong and sharp. They begin at the umbilical suture line and swing somewhat back on the rounded umbilical wall. The primaries are straight on the whorl sides except near the aperture where they are slightly proconvex. They have a forward inclination of about $10^{\circ}$. The primary ribs split up into secondary ribs at $73 \%$ of the whorl height. On the body chamber there are mostly two and sometimes three secondaries per primary rib. The secondary ribs are a little more inclined forward than the primaries. The secondary ribs are interrupted along a short siphonal furrow at the beginning of the body chamber. The specimen seems to be a complete adult, because the last primary ribs are slightly proconvex and approximated.

Discussion: AkKELL (1937,p.90) assigned the name rotoides to small Dichotomosphinctes of the Antecedens Subchron in England. He did not measure the innermost whorls of the cast of RONCHADZE's holotype exactly enough to recognize that the rib curve first falls to the diameter of $40 \mathrm{~mm}$ and only then begins to ascend (ARKELL, 1937, text-fig. 23, compare with text-fig. 47 of this paper). ENAY (1966, fig. 137) has measured the inner whorls of the holotype in more detail, but the subtle morphological difference in the ribbing as well as the considerable age difference between the French and the English material apparently did not occur to him.

On September 3 in 1980 the upper part of the section RG 276 at Holderbank AG has been re-excavated. Four specimens of Perisphinctes roloides RONCHADZE could be collected from bed 46 (GyGi \& PERsoz 1986, p. 422), this is to say from ahove bed 42 with Larcheria schilli (OPPEL). It became apparent from the rib curves that these specimens were early representatives of Dichotomoceras MNHB J 27971 as described above agrees very well with the holotype of roioides RONCHADZE 1917.

R. Gygi explained this to E. Cariou when he inspected his collection at Basel in 1987. This lead CARTOU of MeIExdez (1990, p. 144) and CAriou et al. (1991, p. 704) to introduce a new Rotoides Subzone based on section RG 276 at Holderbank. Switzerland, (see GyGı 1990b), a section near Pamproux, France, and another section at Moscardon, Spain. Therefore Perisphinctes (Dichotomosphinctes) rotoides ARKELL, non RONCHADZE has to be given a new name. During the preparation of this manuscript, GLownLAK (1997, p.45) named it arkelli n.sp.

Age of MNHB J 27971: Rotoides Subchron of the Bifurcatus Chron.

\subsubsection{Perisphinctes (Dichotomoceras) stenocycloides SIEMIRADZKI 1898 P1. 9, fig. 3}

Synonymy

1989 Perisshinctes (Dichotomoceras) stenocycloides SiemiradDZK1 - Melendez. p. 311.pl.51, figs 1-5, with synoymy

Material: MNHB J 23728

Locality: section RG 276, GyGi et al. (1979, fig. 3), Chalch quarry, Holderbank AG, bed 50, lower Effingen Member. The specimen has been excavated in 1975 , at a time, when the section of the Birmenstorf and the lower Effingen Member was only partially visible. The complete section RG 276 became accessible in 1978 and was then measured. The fossil horizons excavated in 1975 could then be casily identified, because the outcrop runs very obliquely through the section.

Description: The specimen is compressed in an axial plane of the spiral. The diameter, the whorl height and the umbilicus have therefore been measured in the axial plane which is at an angle of $45^{\circ}$ against the plane of maximum compression.

$\begin{array}{llll}\text { Dimensions: } & \text { D } & 92 \mathrm{~mm} & \\ \text { Wh } & 28 \mathrm{~mm} & 30 \% \\ \text { Wt } & 26 \mathrm{~mm} & 28 \% \\ \text { U } & 44 \mathrm{~mm} & 48 \%\end{array}$

The carbonate internal mould is septate to the diameter of ca $75 \mathrm{~mm}$. Two thirds of the last whorl are occupied by the body chamber. The primary ribs are strong, sharp and straight on the whorl sides. They begin on the lower part of the rounded umbilical wall. On the wall they are either straight or swing a little backward. At the whorl sides the primary ribs have a forward inclination of $0-5^{\circ}$. They split into two secondary ribs at $75 \%$ of the whort height. The forward inclination of the secondaries is greater than that of the primaries. The secondary ribs form a proconvex arc on the siphonal side. They are strong and sharp as 
the primaries At the end of the phragmocone and at the beginning of the body chamber there is a shallow siphonal furrow that reduces the height of the secondary ribs. The last whorl covers the preceding one by $25 \%$, so that the point of bifurcation of the primary ribs lies just beneath the umbilical suture line.

Discussion: On the last but one whorl of SIEMIRADzki's holotype the point of bifurcation of the primary ribs is visible. This is also the case with the specimens figured by Duong (1974, pl. 7, figs. 1 and 5). This seems to be a minor difference between MNHB J 23728 and the holotype. All other measurable characters agree well with the type.

Age: Stenncycloides Subchron of the Bifurcatus Chron.

\subsubsection{Perisphinctes (Dichotomoceras) bifurcatoides ENAY 1966 \\ Pl. 9, fig. 2 - text-fig. 48}

\section{Synonymy}

1989 Perisphinctes (Dichotomoceras) bifurcaloides ENAY-Melendez,p.315, pl.52, fies 1-3,pl.53. figs.1-3, pl. 54. figs. $1-4$, with synonymy

\section{Material: MNHB J 23704}

Locality: section RG 276, Grat et al. (1979, fig. 3), Chalch quarry, Holderbank AG, bed 50, lower Effingen Member.

$\begin{array}{llll}\text { Description: Dimensions } & \text { D } & 101.6 \mathrm{~mm} & \\ \text { Wh } & 33.0 \mathrm{~mm} & 32 \% \\ \text { Wt } & - & - \\ \text { U } & 45.0 \mathrm{~mm} & 44 \%\end{array}$

The carbonate internal mould is septate to the diameter of $58 \mathrm{~mm}$. Three fourths of the last whorl are occupied by the body chamber. The primary ribs begin on the rounded umbilical wall. There they swing backward. On the sides of the inner whorls the primary ribs are straight and have a forward inclination of about $10^{\circ}$. They are strong and sharp, On the body chamber the inclination of the primaries decreases to zero. On the rear part of the body chamber they are proconcave, but they become proconvex near the aperture. At about $75 \%$ of the whorl height the primary ribs split into two secondary ribs. On the body chamber are two unsplit primaries and one intercalated secondary rib. The secondary ribs are strong and high. Their forward inclination is greater than that of the primaries. The last whorl covers the preceding one by ca $25 \%$.

Age: Stenocycloides Subchron of the Bifurcatus Chron.

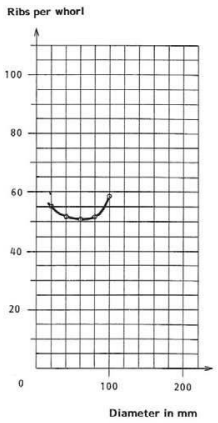

Fig. 48: Rib curve of Perisphinctes (Dichotomoceras) bifurcatoides Enay MNHB J 23704.

\subsubsection{Perisphinctes (Dichotomoceras) duongae Melendez 1984, emend. GygI Pl. 9. fig. 4-text-fig. 49}

Synonymy

1984 Perisphinctes (Dichotomoceras) duongi sp. nov. - MELENDEZ. p. 643 , pl. 56 , figs. $1-6$

1989 Perisphinctes (Dichotomoceras) duongi sp, nov. - MELENDEZ. p. 325 , pl. 56 , figs. $1-6$

Emendation: MELENDEZ (1984, p.643) introduced the name duongi in order to honour the late Miss Dara-Moni Duong of Cambodia, author of Duong (1974). According to the articles 31 and $32 \mathrm{c}$ of the INTERNATIONAL. CODE OF ZOOLOGICAL Nomenclature (1985), the name must be changed into duongae because of the female sex of the person the name relates to.

\section{Material: MNHB J 23533}

Locality: section RG 226, R. GYG (1973, fig. 3), road cut north of Jakobsberg quarry, Auenstein AG, not in situ, lower Effingen Member.

$\begin{array}{llll}\text { Description: Dimensions } & \text { D } & 90 \mathrm{~mm} & \\ \text { Wh } & 29 \mathrm{~mm} & 32 \% \\ \text { Wt } & 25 \mathrm{~mm} & 28 \% \\ \text { U } & 38 \mathrm{~mm} & 42 \%\end{array}$




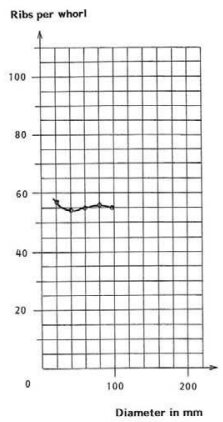

Fig. 49: Rib curve of Perisphinctes (Dichotomoceras) dnongae MELENDEZ MNHB J 23533.

The carbonate internal mould is septate to the diameter of $62 \mathrm{~mm}$. Three quarters of the last whorl are occupied by the body chamber. The primary ribs begin on the perpendicular umbilical wall where they are inclined backward. The primary ribs are straight on the subparallel, slightly convex whorl sides. They are strong and sharp. Their forward inclination is about $30^{\circ}$ on the innermost preserved whorl and decreases to $8^{\circ}$ on the body chamber. The primary ribs split at $69 \%$ of the whorl height into two secondaries. The secondary ribs are also strong and sharp. Their forward inclination is only a little greater than that of the primaries. They form a proconvex arc on the siphonal side. There is a short, very shallow siphonal furrow at the end of the phragmocone and at the beginning of the body chamber. The last whorl covers the preceding one by $32 \%$, so that the points of bifurcation of the primary ribs are only occesionally visible on the inner whorls.

Age: According to MELENDEZ (1989,p. 330), the taxon oceurs in the late Stenocycloides Subchron of the Bifurcatus Chron.

\subsubsection{Perisphinctes (Dichotomoceras) cf. bifurcatus (OUENSTEDT 1847) P1. 8 , fig. 3}

\section{Material: MNHB J 23543}

Locality: section RG 226, GyGt (1973, fig. 3), road cut north of Jakobsberg quarry, bed $55,2.3 \mathrm{~m}$ above the base, lower Effingen Member.
Description: The specimen is compressed in the equatorial plane as well as slightly in an axial plane. The dimensions of the specimen have therefore been measured in the axial plane which is inclined $45^{\circ}$ to the axial plane of maximum compression. The measured dimensions are then only approximate:

$\begin{array}{lll}\text { D } & 55 \mathrm{~mm} & \\ \text { Wh } & 18 \mathrm{~mm} & 33 \% \\ \text { Wt } & - & - \\ \text { U } & 23 \mathrm{~mm} & 42 \%\end{array}$

The marly internal mould is septate to the diameter of probably $52 \mathrm{~mm}$. Somewhat less than a fourth of the last whorl is occupied by the body chamber. The primary ribs begin at the umbilical suture line. They swing back very little on the rounded umbilical wall. On the whorl sides the primary ribs are straight. Their forward inclination is $0-5^{\circ}$. The primaries split into two secondary ribs relatively low, this is to say at $63 \%$ of the whorl height. The secondaries are slightly bent forward. The last whorl covers the preceding one by only $17 \%$, so that the point of division of the primary ribs is well visible on the inner whorls. In a letter dated at 9 December 1996. R. Enay remarked that the ribbing in this specimen is too dense for a typical bifurcatus.

Age: later part of Bifurcatus Chron.

Genus Subdiscospltinctes MALINowsKA 1972 a

Subgenus Subdiscosphinctes MaL.nowska 1972 a

Subgeneric type species: Perisphincles kreutzi SifmiradzKI 1891

\subsubsection{Subdiscosphinctes (Subdiscosphinctes) lucingae (FAVRE 1875) \\ Pl. 5, fig. 1 - text-fig. 50}

\section{Synonymy}

1966 Lithacoceras (Discospininctes) lucingae (FAVRE) - ENAV, p. 540, figs. $166,169 / 10-12$, pl 37 , fig. 10, with synonymy

v 1989 Subdiscospininctes (Subdiscosphinctes) lucingae FAvREFischer \& Grol, fig. 6A

\section{Material: MNHB J 23755}

Locality: section RG 60, GyGi (1969, pl.17), Eisengraben, Gansingen AG, not in situ, collected from the upper Birmenstorf Member.

$\begin{array}{llll}\text { Description: Dimensions } & \text { D } & 99 \mathrm{~mm} & \\ \text { Wh } & 36 \mathrm{~mm} & 36 \% \\ & \text { Wt ca } & 27 \mathrm{~mm} & 27 \% \\ \text { U } & 37 \mathrm{~mm} & 37 \%\end{array}$

The carbonate internal mould is septate to the diameter of $58 \mathrm{~mm}$. The body chamber occupies three quarters of the last whorl. The primary ribs begin in the upper part of the rounded 


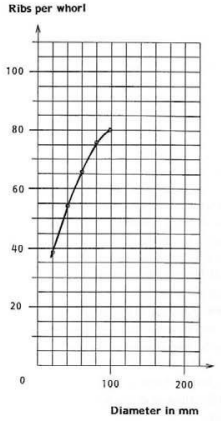

Fig. 50: Rib curve of Subdiscosphinctes (Subdiscrsphinctes) lucingae (FAVEE) MNHB J 23755.

umbilical wall. They swing somewhat back on the umbilical margin. On the slightly convex whorl sides of the phragmocone the primary ribs are straight and lean $12^{\circ}$ forward. On the body chamber the primaries become increasingly proconcave. Some of them are undivided, but most of them split into two secondary ribs at $67 \%$ of the whorl height. The undivided primary and the sccondary ribs bend very little forward on the siphonal margin and so form a proconvex arc on the siphonal side. Constrictions are common on the inner whorls. There are four constrictions on the last whorl.

Age: Luciaeformis Subchron of the Transversarium Chron.

Subgenus Aureimontanites Brochwicz-LEWINSKI 1975a

Subgeneric type species: Lithacoceras (Subdiscosphincres) boreale MALINowsKa 1972 a

\subsubsection{Subdiscosphinctes (Aureimontanites) wojciechi n. sp. \\ Pl. 8 , fig. 5 - text-fig. 51}

Synonymy

\footnotetext{
1972a Lithacoceras (Subdiscosphinctes) kreutzi (SiEMIRADzKI) MA_.nowska, p. 221, pl. 27, fies, 1, 2, pl. 28

1972 Lirhacoceras (Lithacoceras) kreuizi (SIEMIRADZK1) Brochwicz-LEWixski, pls 1, 2,3,4
}

1975a Lithacoceras (Lithacoceras) kreutzi (SIEMIRADZKI) BroCHWICZ-LEWINSKI, pl. 21.fig 2

1975a Perisphinctes kreutzi SIEMIRADZKI - Brocuwicz-LewINSKI, pl. 22, fig. 1

1975a Lithacoceras (Lithacoceras) kreutzi sensu BRochwicz-LeWTVSKI, 1972 - BROCHWICZ-LEWINSKI, pl. 22, fig. 2

? 1975a Lithacoceras (Snbdiscosphinctes) kreutzi sensu MaLıNowska. 1972 - Brochwicz-Lewinski, pl. 22, fig. 3

Holotype: Original to BrochwICz-LEWINSKI, 1972, pl.1, Warsaw University. Institute of Geology, Br 02/204.

Type locality: Zawodzie, Poland

Type horizon: Platy limestones.

Derivation of the name: In honour of Wojciech Brochwicz. Lewinski, author of many papers on Oxfordian perisphinctids in Poland.

Diagnosis: Species of the subgenus Aureimontanites with fine biplicate ribbing on the inner whorls and swollen, distant primary ribs on the body chamber. The diameter of the complete adult can be as much as $300 \mathrm{~mm}$.

Material: MNHB J 23659

Locality: section RG 230, GYGI (1977, pl.11, fig. 3), excavation north of Eisengraben. Gansingen AG, upper Birmenstorf Member.

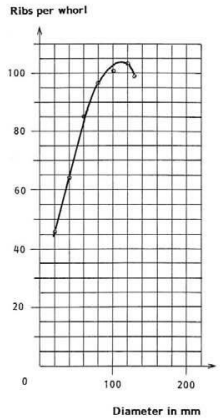

Fig.51: Rib curve of Subdiscosphinctes (Aureimontanites) wojciechi ก. sp. MNHB J 23659. 
Description: Dimensions D $119 \mathrm{~mm}$

Wh $43 \mathrm{~mm} 36 \%$

Wt $29 \mathrm{~mm} 24 \%$

U $\quad 44 \mathrm{~mm} \quad 37 \%$

The carbonate internal mould is septate to the diameter of $123 \mathrm{~mm}$. One eighth of the last whorl is occupied by the body chamber. The fine primary ribs begin above the smooth umbilical wall, on the rounded umbilical margin where they swing backward. On the slightly convex whorl sides the primary ribs are either straight or somewhat proconcave. There they have a forward inclination of $12-15^{\circ}$. At $79 \%$ of the whorl height the primary ribs generally split into two secondary ribs, but many primaries ate undivided. The simple primary ribs and the secondaries bend forward on the siphonal margin and form a proconvex arc on the rounded siphonal side. The ribs are not attenuated near the siphuncle. The rib curve (fig. 51) rises in a straight line from the diameter of $20 \mathrm{~mm}$ to $60 \mathrm{~mm}$. The curve reaches a peak before the diameter of $120 \mathrm{~mm}$ with 103 ribs per whorl and then begins to descend. The specimen is therefore a macroconch and belongs to the subgenus Aureimontanites.

Affinities: The inner whorls of Subdiscosphinctes (Aureimontanites) wojciechi n. sp. resemble Subdiscosphinctes (Subdiscosphinctes) kreutzi (SIEMIRADZK1) so much that there can be no doubt that the new taxon is the macroconch of Subdiscosphinctes (Subdiscosphinctes) kreutzi, as has been assumed by BRoCHWICZ-LEWINSKI (1972,p. 478). BROCHWICZ-LEWINSK1 \& RozaK (1976a, p. 115) have drawn attention to difficulties in recognizing the dimorphism of certain perisphinctids. It is therefore unadvisable to give the same specific name to the macroconch and the microconch of a dimorphic pair as has been suggested by Makowski (1963,p. 18). A new specific name is therefore needed as is proposed here.

Agc: Luciacformis Subchron of the Transversarium Chron.

\subsubsection{Subdiscosphinctes (Aureimontanites) cracoviensis (SIEMIRADZKI 1891) \\ Pl. 7, fig. 1 - text-fig. 52}

Synonymy

1891 Perisphinctes Cracoviensis n.sp.-SIEMIradzKI, p. 48. pl.3. figs 1.4

non 1898 Perisphinctes cracoviensis SiEMIRADZKI - DE RIAZ, p. 35, pl. 15, fig. 1

1972 Lithacoceras (Discosphincres) cracoviense (Stesurapzki) BrochWTcz-LewiNski, p. 484, pl. 10, 11, 12, fig. 2

1976a Subdiscosphinctes cracoviensis (Siemikadzki) Brochwicz-LeWINsKl \& RozAK, pl. 30

\section{Material: MNHB J 23655}

Locality: section RG 230, GYG1 (1977, pl. 11, fig. 3), excavation north of Eisengraben, Gansingen AG, upper Birmenstorf Member:

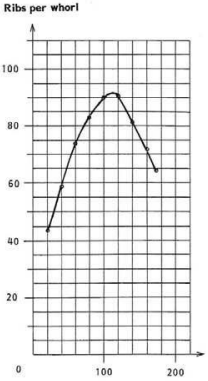

Diameter in $\mathrm{mm}$

Fig. 52: Rib curve of Subdiscosphincies (Aureimontanites) cracoviensis (SiemiradZKI) MNHB J 23655.

$\begin{array}{llll}\text { Description: Dimensions } & \text { D } & 163 \mathrm{~mm} & \\ & \text { Wh } & 56 \mathrm{~mm} & 34 \% \\ & \text { Wt } & - & - \\ \text { U } & 64 \mathrm{~mm} & 39 \%\end{array}$

The carbonate internal mould is septate to the diameter of $101 \mathrm{~mm}$. More than $80 \%$ of the last whorl are occupied by the body chamber. On the inner whorls the primary ribs begin at the umbilical suture line. From there to the rounded umbilical margin the primaries bend slightly back. On the somewhat convex whorl sides the primary ribs are straight and lean $8-15^{\circ}$ forward. The whorl section is oval. The low ribs are fine and blunt. On the body chamber the primaries become proconcave. There they start on the umbilical margin and leave the umbilical wall smooth. Many of the primary ribs are undivided on the phragmocone. The majority of them splits into two secondary ribs at about $60 \%$ of the whorl height. On the body chamber the number of secondary ribs per primary rib increases from two to four towards the aperture, and the point of division becomes more and more diffuse. The forward inclination of the secondary ribs with respect to the primaries is slight on the phragmocone and diminishes to zero at the end of the body chamber. The last whorl covers the preceding one by $42 \%$. No constrictions are visible on the inner whorls, but on the body chamber there are two of them. The rib curve (fig. 52) rises steeply to the diameter of $115 \mathrm{~mm}$ and then descends just as steeply.

Age: Luciaeformis Subchron of the Transversarium Chron. 
Genus Larcheria Tintant 1961

Type species: Larcheria larcheri TinTANT 1961

\subsubsection{Larcheria schilli (OPPEL 1863)}

Pl. 8, fig. 2-text-fig. 53

\section{Synonymy}

? 1966 Lithacoceras (Larcheria) schilli (OPPEL) - ENAY. p. 529, pl. 36 , fig 3 , with synonymy

1982 Larcheria aff. schilli (OPPEL.) - Marchand el al.,p. 104, pl.1, fig. 1

1984 Larcheria schilli (OPPEL) - MELENDEZ et al.,pl.4, fig. 2,pl.5, iig. 2

1990 Larcheriu schilli (OpPEL) - Fontana, pl. 4. fig. 1

Material: MNHB J 23534

Locality: section RG 226, GYG1 (1973, fig. 3), road cut north of Jakobsberg quarty, Auenstein AG, bed 46? not in situ, lower Effingen Member.

Description: Dimensions D $80.6 \mathrm{~mm}$

Wh $30.0 \mathrm{~mm} \quad 37 \%$

Wt $\quad 22.0 \mathrm{~mm} \quad 27 \%$

U $\quad 30.0 \mathrm{~mm} \quad 37 \%$

The carbonate internal mould is septate to the diameter of $62 \mathrm{~mm}$. The body chamber occupies the last half whorl. The primary ribs begin on the rounded umbilical margin. The lower part of the umbilical wall is smooth. The ribs first bend a little backward. On the converging whorl sides the primary ribs lean $8-10^{\circ}$ forward. The primaries are straight or slightly proconvex. At half the whorl height the primary ribs are attenuated, so that the point of division into secondary ribs becomes indistinct. The primary ribs split into two or three secondaries at about $60 \%$ of the whorl height. The secondary ribs bend forward. They form a proconvex arc on the rounded siphonal side. The last whorl covers the preceding one by $36 \%$.

Age: Schilli Subchron of the Bifurcatus Chron.

Genus Passendorferia Brochwicz-Lewinski 1973

Subgenus Passendorferia BRochwicz-LEWINski 1973

Subgeneric type species: Passendorferia teresiformis BrochWICZ-LEWINSKI 1973

\subsubsection{Passendorferia (Passendorferia) ziegleri \\ (BROCHWICZ-LEWINSKI 1973) \\ Pl, 6. fig. 1 - text-fig. 54}

\section{Synonymy}

y 1973 Nebroditer (Passendorferia) ziegleri n. sp.Bnochwicz-Lewinski, p.311, pls. 15-18, pl. 22, fig. 2

c.. 1974 Perisphinctes (Arisphinctes) plicatilis (SOWERBY)SEqueIros, p. 160, pl.18, fig. 2
Ribs per whorl

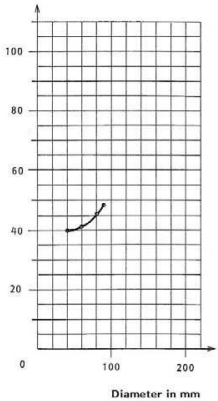

Fig.53: Rib curve of Larcheria schilli (OPPLL) MNHB .I 23534.

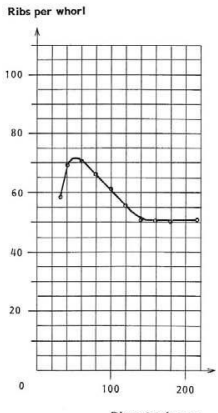

Diameter in $\mathrm{mm}$

Fig.54. Rib curve of Passendorferia (Pussendorferia) zitegleri (BrochWICZ-LEWINSKI) MNHB J 24079. 
1976 Passendarferia ziegleri (Brochwicz-Lewinski) SAPUNOY, pl. 6. fig. 2

cl. 1977 Passendorferia ziegleri BRocuwicz-LEwinski SEqueIros, p. $360, \mathrm{pl} .2$

non 1977 Passendorferia ziegleri Brocarwicz-LEWINski SequHizos, pl.3, fig. 3

cf. 1984 Passendorferia (Passendorferia) of ziegleri Brocinwicz-Lewinski) - Melendez. p. 255.pl.2, fig. 2

cf. 1989 Passendorferia (Passendorforia) of ziegleri (Brochwicz-LewINSKI) - MELENDEZ. p. 138, pl.2, fig. 2

Material: MNHB J 24079

Locality: section RG 230, GyG (1977, pl.11, fig. 3), excavation north of Eisengraben, Gansingen AG, upper Birmenstorf Member.

$\begin{array}{rlll}\text { Description: Dimensions } & \text { D } & 269 \mathrm{~mm} & \\ \text { Wh } & 57 \mathrm{~mm} & 21 \% \\ & \text { Wt } & - & - \\ \text { U } & 168 \mathrm{~mm} & 62 \%\end{array}$

The carbonate internal mould is septate to the diameter of $212 \mathrm{~mm}$. The body chamber of the undamaged specimen occupied at least two thirds of the last whorl. The primary ribs are fine and blunt on the inner whorls. On the outer whorls they become stronger and disproportionally widely spaced. The primary ribs are straight and radial. They begin close to the umbilical suture line. At the diameter of $150 \mathrm{~mm}$ many primary ribs split into two low, blunt secondary ribs at about $80 \%$ of the whorl height. The last split rib is at the diameter of $180 \mathrm{~mm}$. From there on the ribs are simple and become stronger towards the aperture. They are not attenuated at the siphonal side. The whorl section is nearly circular on the inner whork. The outer whorls are trapezoidal with rounded umbilical and siphonal margins. The siphonal side is rounded. The coiling is extremely evolute, serpenticone. The last whorl covers the preceding one by only $10 \%$. Constrictions oceur cvery three fourth of a whorl at small diameters and every two third of a whorl at great diameters.

Age: Luciaeformis Subchron of the Transversarium Chron.

Subgenus Enayites BrochwiCZ-LEwINSKI \& ROZAK 1976

Subgencric type species: Ammonites birmensdorfensis MOESCH 1867

\subsubsection{Passendorferia (Enayites) birmensdorfensis (MoEsCH 1867) \\ Pl. 5, fig. 2-texL-fig. 55}

\section{Synonymy}

1989 Passendorferia (Enayites) birmensdorfensis (MOEscH) MrieNDEZ, p. 157, pl.11, figs 5-12, with synonymy

? 1990 Passendarferia (Enayites) birmensdorfensis (MOESCH) Clak1 el al., pl. 1, fig 1

Material: MNHB J 31607

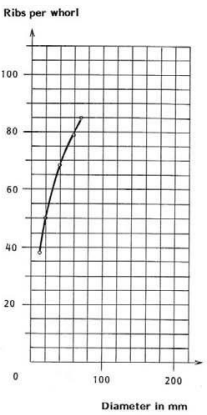

Fig.55: Rib curve of Passendorferia (Enayites) birmensdorfeasis (MоEsch) MNHB J 31607.

Locality: section RG 32, GYor (1969, pl.17), Schellenbrücke. Küttigen AG, bed 7, lower Birmenstorf Member.

$\begin{array}{lll}\text { Description: Dimensions } & \text { D } & 69.0 \mathrm{~mm} \\ & & \\ \text { Wh } & 18.3 \mathrm{~mm} & 27 \% \\ \text { Wt } & - & - \\ \text { U } & 37.0 \mathrm{~mm} & 54 \%\end{array}$

The carbonate internal mould is septate to the diameter of $38 \mathrm{~mm}$. The entire last whorl is occupied by the body chamber. The last two septa are approximated. The specimen then is an adult microconch. The peristome is broken off. The fine primary ribs begin just above the umbilical suture line and are straight and radial. About half of them are undivided. The others split into two secondary ribs at about $75 \%$ of the whorl height. The last whorl covers the preceding one by only about $10 \%$. Nevertheless, the points of division of primary ribs are not visible on the inner whorls. The secondary ribs are radial just like the primaries. At the beginning of the body chamber they fade away almost completely along a narrow and shallow furrow along the siphonal line. The whorl section is almost circular to thick-oval. Constrictions appear about every three quarters of a whorl.

Age: Luciaeformis Subchron of the Transversarium Chron. 
Genus Wegelea nov. gen.

Type species: Perisphinctes gredingensis WeGELE 1929, p.49. pl.1. fig. 7 (holotype by monotypy).

Diagnosis: Large perisphinctid with a relatively narrow umbilicus. The ribbing is weaker and blunter than in Larcheria. The whorls are much higher than thick. The peristome is simple, without lappets.

Derivation of the name: The name refers to L. Wegele, the author of Perisphinctes gredingensis.

Temporal range: Late Bimammatum Chron.

\subsubsection{Wegelea gredingensis (WEGELE 1929)}

Pl. 13, fig. 1 - text-fig. 56

Synonymy

1929 Perisphinctes gredingensis n. sp - WEGKL.E, p. 49, pl. 1, fig. 7

Material: MNHB J 31720

Locality: section RG 85 (detailed section unpublished, for condensed version see GyGt, 1969, pl.19, upper section), Wisse Rise, Beggingen $\mathrm{SH}$, bed 55, upper Küssaburg Member.

Description: Dimensions D $145 \mathrm{~mm}$

$\begin{array}{lll}\text { Wh } & 50 \mathrm{~mm} & 34 \% \\ \mathrm{Wt} & 23 \mathrm{~mm} & 16 \% \\ \mathrm{U} & 55 \mathrm{~mm} & 38 \%\end{array}$

The carbonate internal mould is septate to the diameter of about $71 \mathrm{~mm}$. Only traces of septal sutures can be seen. Probably the entire last whorl is occupied by the body chamber. The primary ribs begin on the rounded umbilical margin where they swing back. The primary ribs are straight on the whorl sides. Their forward inclination may be as much as $18^{\circ}$ on the inner whorls and diminishes to zero near the aperture. The primary ribs are weak and blunt. They split at about half the whorl height into two or three secondary ribs at the beginning of the body chamber. Further towards the aperture there are regularly three secondaries per primary rib. The primary ribs become so faint in the middle of the whorl height of the body chamber that the point of division into secondaries is indistinct. The secondaries bend slightly forward at the siphonal margin, but they become radial near the aperture. The strength of the secondary ribs increases from the point of division to the siphonal line where the ribs are relatively strong, but blunt. The last whorl covers the preceding one by $33 \%$. The whorl section is highoval with the greatest thickness not far above the umbilical margin. A premature peristome is visible close to the end of the last whorl (pl.13, fig.1).

Discussion: It is difficult to assign this characteristic perisphinctid with a relatively narrow umbilicus, weak and blunt ribs and an attenuation of the ribbing on the whorl sides to an existing

\section{Ribs per whorl}

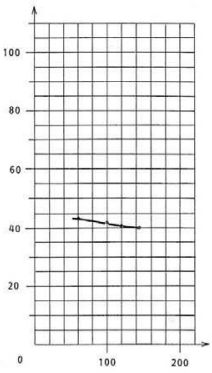

Diameter in mm

Fig. 56: Rib curve of Wegelea gredingersis (WegetE) MNHB J 31720.

genus. Tintant (1959, p. 129) thought it was a Larcheria and ENAY $(1964, p .493)$ followed him in this. Indeed, Wegelea n. $g$ is morphologically very close to Larcheria, but there is a time gap of three subzones between the two genera without intermediate forms. ENAY (1966, p. 518) classed Wegelea gredingerisis with Orthosphinctes and assumed it was a microconch. This cannot be done, because the umbilicus of Wegelea gredingensis is too narrow for Orthosphinctes. Moreover, the ribbing of Wegelea gredingensis cannot be compared with the ribbing of Orthosphincles. The peristome of Wegelea is simple, without lappets. These are the reasons why the new genus has been introduced above.

Age: Hauffianum Subchron of the Bimammatum Chron.

Subfamily Idoceratinae SPATH 1924

Genus Idoceras BURCKHARDT 1906

Type species: Ammonites planula HEHL in ZIETEN 1830.

\subsubsection{Idoceras balderum (OPPEL 1863) PI. 14, fig. 3}

Synonymy

1863 Ammonites Balderus Opp,--Oppel, p. 242, pl.67, fig. 2

1878 Ammanites balderis OPPEI.- DE LOLRIOL, p. 94, pl. 15, fig 7 . non fig. 8

1929 leloceras Balderis OpPEL - WeGELE, p. 78,pl.9, fig.7 
1959 Idoceras balderum (OPPEL) - ZiEgLer, p. 25, pl. 1, figs. 3.4

1977 Idoceras (Idoceras) baldenum (OPPEL) - ZIEGLER, pl.3, fig. 5

1980 Idnceras halderum (OPPEI) - BNRTHEL. \& Schatrer, pl. 1. figs, 1.3. 4

1987 Idoceras balderum (OPPEL) - ZIEGL.ER, pl. 2, fig. 2

\section{Material: MNHB J 31719}

Locality: section RG 62, Grat $(1969, \mathrm{pl} .17)$, cliff west of Besserstein ruin, Villigen AG, bed 124, lower Wettingen Member.

Description: Dimensions D $48.0 \mathrm{~mm}$

\begin{tabular}{|c|c|}
\hline Wh & $18.0 \mathrm{~mm}$ \\
\hline $\mathrm{Wt}$ & - \\
\hline U & $18.0 \mathrm{~mm}$ \\
\hline
\end{tabular}

The carbonate internal mould was found lying flat at the upper surface of a limestone bed. It is diagenetically compressed. The inner whorls are totally flattened. The last septum of the phragmocone can be seen only indistinctly on one side. The entire last whorl is occupied by the body chamber. The primary ribs on the rcar part of the body chamber either split into two secondary ribs or remain simple. On the last half of the body chamber the primary ribs fade away completely at half the whorl height. Only close to the siphonal margin appear low, blunt secondary ribs that are interrupted along the siphonal line. The secondaries bend strongly forward near the aperturc. This and their "flattened" appearance (see ZIEGLER, 1959, p.26) indicate that the specimen is adult in spite of its small size.

Age: Divisum Chron.

Genus Subnebrodiles SPATH 1925

Type species: According to a letter by F. Atrops dated 16 September, 1996: Ammonires planula Quenstedr (1888, pl.108. fig. 2).

\subsubsection{Subnebrodites planula (QUENSTEDT 1888) Pl. 11, fig. 5}

Synonymy

1888 Anmonites planula gigas - QUENSTEDT, p. 978, pl. 108, fig. 2 pars 1989 Idoceras (Subrebrodites) planula (HeHz in 71ETEN. 1830) SCHARER, p. 99, pl.1, figs $1-5$, pl. 2, figs. 1-2, pl.3, figs.1-2, ? pl.4. tig, 1, with synonymy

Material: MNHB J 31723

Locality: section RG 84 (detailed section unpublished, for condensed version see Grai, 1969, pl. 19, upper section), township quarry. Hemmenthal SH, lower Wangental Member.

Description: Dimensions D $77 \mathrm{~mm}$

\begin{tabular}{|c|c|}
\hline Wh & $25 \mathrm{~mm}$ \\
\hline $\mathrm{Vt}$ & - \\
\hline & $35 \mathrm{~m}$ \\
\hline
\end{tabular}

The carbonate internal mould is septate to the diameter of about $84 \mathrm{~mm}$. The body chamber occupied at least three quarters of the last whorl. The complete specimen must have had a diameter of about $100 \mathrm{~mm}$. The inner whorls are finely ribbed. but on the body chamber the primary ribs are coarse and widely spaced. The secondary ribs bend strongly forward and fade entirely along the siphonal line. The whorl section is elliptic.

Age: early Planula Chron.

\subsubsection{Subnebrodites laxevolutus (Fontannes 1879) Pl. 11, fig. 4}

Synonymy

1959 Idoceras laxevolutum (FoNTANNES) - ZIEGLER, p. 28, pl.1. fig. 6 , with synonymy

71974 lidoceras larevolita (FonTANNes) - BARBULESCU.pl, 41 figs. $5-6$

pars 1989 Idoceras (Subnebrodites) laxenohutum (FonTaNines) sensu ZifGL.F. 1959 - SchatRer. p. 101. pl.4, figs. 2-7.pl. 5. figs. $1-4$, with synonymy

\section{Material: MNHB J 32275}

Locality: section RG 70 , GyGI $(1969, \mathrm{pl} .17)$, large quarry, Mellikon AG, bed 108, upper Letzi Member.

Description: Dimensions D 87 mit

$\begin{array}{lll}\text { Wh } & 28 \mathrm{~mm} & 32 \% \\ \text { Wt } & - & - \\ \mathrm{U} & 41 \mathrm{~mm} & 47 \%\end{array}$

The carbonate internal mould is septate to the diameter of $55 \mathrm{~mm}$. The body chamber occupies seven eighths of the last whorl. The body chamber is diagenetically compressed, whereas the phragmocone is almost completely flattened. The primary ribs begin at the umbilical suture line and lean a little forward on the whorl sides. The majority of them splits into two secondary ribs. The secondary ribs bend forward and are strongly attenuated along the siphonal line. There are 43 primary ribs on the last whorl.

Age: Planula Chron.

\subsubsection{Subnebrodites schroederi (WEGELE 1929) Pl. 13. fig. 4}

Synonymy

pars 1989 ldoceras (Subnebrodites) schroederi WEGEL.E - SCHAIRER. p.104. pl.7, figs 1-8, with synonymy

Material: MNHB J 31714

Locality: section RG 82, GYG (1969, pl. 16), quarry below Steimürlichopf in Churz Tal, Siblingen SH, bed 134, lowermost Wangental Member. 
Description: Dimensions D $78 \mathrm{~mm}$

$$
\begin{array}{lll}
\text { Wh } & 26 \mathrm{~mm} & 33 \% \\
\text { Wt } & 17 \mathrm{~mm} & 22 \% \\
\text { U } & 33 \mathrm{~mm} & 42 \%
\end{array}
$$

The carbonate internal mould is septate to the diameter of $47 \mathrm{~mm}$. Threc quarters of the last whorl are occupied by the body chamber. The primary ribs swing somewhat back on the umbilical margin. On the whorl sides the ribs are straight or slightly proconcave and lean about $5^{\circ}$ forward. The great majority of them splits into two secondary ribs. Only one primary rib is unsplit on the last whorl. The secondary ribs are interrupted along a relatively wide band along the siphonal side. The last whorl covers the preceding one by $34 \%$. There are 35 primary ribs on the last whorl.

Age: early Planula Chron.

Family Ataxioceratidae BUCKMAN 1921

Subfamily Ataxioceratinae BUCKMAN 1921

Genus Orthosphinctes SCHINDEWOLF 1925

Subgenus Orthosphinctes SCHINDEWOL F 1925

Subgeneric type species: Ammonites tiziani OPPEL 1863.

\subsubsection{Orthosphinctes (Orthosphinctes) colubrinus (REINECKE 1818) \\ Pl. 11, fig.6, pl.13, fig. 5-text-fig. 57}

\section{Synonymy}

1966 Orthosphinctes (Orthosphinctes) colubrinus (REINECKE) ENAY,p.515, with synonymy

non 1966 Perisphinctes (Orthosplingtes) colubrinus ReINecke - ANDH.KOVIC, p. 45 , fig 39 , pl. 9 , fig. 1

1972 Nautilus colubrinus RerNecke in HeLler \& Zetss, p.27, pl.4. fig. 72

Material: MNHB J 31712, J 32267

Locality of J 31712: section RG 82, GyG (1969, pl.16), quarry below Steimürlichopf in Churz Tal, Siblingen SH, bed 134, lowermost Wangental Member.

$\begin{array}{llll}\text { Description of J 31712: Dimensions D } & 68.6 \mathrm{~mm} & \\ \text { Wh } & 20.0 \mathrm{~mm} & 29 \% \\ \text { Wt } & 18.0 \mathrm{~mm} & 26 \% \\ \text { U } & 31.0 \mathrm{~mm} & 45 \%\end{array}$

The carbonate internal mould is septate to the diameter of $35 \mathrm{~mm}$. The body chamber occupies somewhat more than the last whorl. The last constriction before the peristome is preserved at the end of the body chamber, but the peristome is broken off. The primary ribs begin just above the umbilical suture line and are mostly straight and radial. They are high, but blunt. The primaries split at two thirds of the whorl height into two secondary ribs. Three primary ribs are unsplit on the last whorl. The secondary ribs bend a little forward and form a pro-
Ribs per wher 1

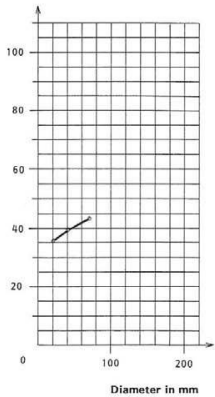

Fig.57: Rib curve of Orthosphinctes (Orthosphinctes) colubrinus (REINECKE) MNHB J 31712.

convex are at the siphonal side. They are slightly attenuated along the siphonal line. The whorl section is oval with the greatest thickness at about one third of the whorl height.

Discussion: The first tens of ammonites listed in the catalog by Schauroth in the Naturkunde-Museum Coburg, Germany, belong probably all to the collection of J.M.C. Reinecke. The largest of the three specimens from Staffelstein listed under the catalog number 42 compares well with the drawing by RE1NECKE (1818, pl.12, fig. 72). Exactly the entire last whorl of the specimen is occupied by the body chamber. In the copy of RE]NECKE's booklet kept at Coburg the broken surface at the aperture is drawn as being smooth. This may be an indication that the type had at least a part of the body chamber. Nevertheless, in the REINECKE copy kept at Bantz castle near Staffelstein, the corresponding drawing no. 72 indicates that the last whorl of the type ends with a septum. The type would then be a phragmocone and be larger than the largest ammonite no. 42 in the Coburg museum. Judging from the Bantz copy, the type would be lost. Under the circumstances, the matter cannot be decided, and the neotype designated by GEYER (1961, p 22, pl.2, fig 3) without knowledge of Reinecke's collection must be further retained.

Age: Earliest Planula Subchron of the Planula Chron. 
Subgeneric type species: Perisphinctes Laufenensis STEMTRADZKI (1898, p. 188, pl. 26, fig. 46), designated by Arnops (1982, p. 50).

\subsubsection{Orthosphinctes (Praeataxioceras) sp.gr. laufenensis (SIEMIRADZKI 1898) \\ Pl. 11, fig. 1-text-fig. 58}

Material: MNHB J 31722

Locality: section RG 76, GYGI (1969, fig, 2), Hornbuck. Erzingen D, bed 12. Hornbuck Member.

$\begin{array}{llll}\text { Description: Dimensions } & \text { D } & 82 \mathrm{~mm} & \\ \text { Wh } & 26 \mathrm{~mm} & 32 \% \\ \text { Wt } & 16 \mathrm{~mm} & 20 \% \\ \text { U } & 39 \mathrm{~mm} & 48 \%\end{array}$

The carbonate internal mould is septate to the diameter of $52 \mathrm{~mm}$. Three fourths of the last whorl are occupied by the body chamber. The specimen is a complete adult with the peristome and a lappet preserved on one side (pl.11. fig. 1b). The primary ribs begin close to the umbilical suture line and are straight and radial. They are low but sharp. At about $60 \%$ of the whorl height they split into two secondary ribs. A third, intercalated secondary rib is added to the majority of the primary ribs. The secondary ribs are radial. The whorl section is elliptic. The last whorl covers the preceding one by less than $20 \%$. Therefore the points of division of the primary ribs are visible on the last but one whorl. There is a straight and deep constriction before the peristome.

Discussion: The described specimen $J 31722$ differs from the description and the figures by SIEmıradzkı in several respects. The whorl sides of the Basel specimen are convex, not flat and converging like in StEmiraKzKi's type. The peristome is straight and radial. Orthosphinctes (Orthosphinctes) polygyratus (QUENSTEDT, 1849, p. 161, pl. 12, fig.3) is similar, but it has a narrower umbilicus and prorsiradiate ribs. The type of Nautilus polygyrafus REINECKE (1818, p. 73, pl.5, figs, 45-46) could not be found in the Naturkunde-Museum Coburg (Germany) where the Reinecke collection is kept. ReINECKE (loc. cit.) stated that his specimens of $N$. polygyratus came from Tremersdorf and Staffelstein. Tremersdorf must be an error, because, according to $E$. Mönnig, curator at the Naturkunde-Museum Coburg, the village of Tremersdorf is situated on Muschelkalk (late Triassic). A large part of the specimens from the Late Jurassic in the Reinecke collection is from Mt. Staffelberg above the town of Staffelstein. The title of REINECKE's booklet says that these ammonites have been collected from a ploughed field. Marly, fossiliferous strata of the earliest Kimmeridgian form a nearly flat surface on the top of Mt. Staffelberg. The type of Nauilus poly. gyratus REINECKE must then be of early Kimmeridgian age, as GEYER (1961, p. 21) concluded when he designated a neotype.

Age: Bimammatum Subchron of the Bimammatum Chron.

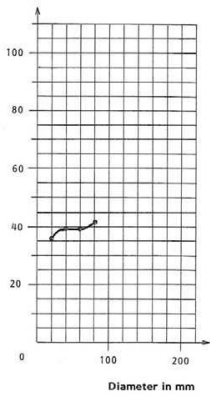

Fig.58: Rib curve of Orthosphinctes (Praearaxioceras) sp, gr. Laufenensis (StemiradZKI) MNHB J 31722.

Genus Ataxioceras FontanNes 1879

Subgenus Parataxioceras SchINDEWoLf 1925

Subgeneric type species: Ammonites lothari Oppet 1863.

\subsubsection{Ataxioceras (Parataxioceras) lothari huguenini Atrops 1982 PI. 14, fig. 2}

Synonymy

1982 Alaxioceras (m. Paralaxioceras) lothari huguenini n. ssp. ATrons, p. 206, pl. 7, figs. 3-4, pl.9, fig. 4, pl. 44, figs. 3-5, pl. 45 . fig. 3

Material: MNHB J 26388

Locality: section RG 70, GyGt (1969, pl.17), large quarry, Mellikon AG, bed 124, lower Baden Member.

Description: Dimensions D $72.5 \mathrm{~mm}$

$\begin{array}{ccc}\text { Wh } & 27.0 \mathrm{~mm} & 37 \% \\ \text { Wt } & 18.0 \mathrm{~mm} & 25 \% \\ \text { U } & 25.0 \mathrm{~mm} & 34 \%\end{array}$

The carbonate internal mould is septate to the diameter of $47 \mathrm{~mm}$. More than one half of the last whorl is occupied by the body chamber. The primary ribs begin at the umbilical suture line. On the last whorl they first swing back. They become very 
strong and sharp at the umbilical margin, then weaker in the middle of the whorl sides. The primary ribs lean about $7^{\circ}$ forward on the sides of the last whorl. On the inner whoris the forward inclination of the primaries is stronger. There the primaries split into secondary ribs above the middle of the whorl height. On the body chamber the lowest points of division are below half the whorl height. At the end of the body chamber there are five secondary ribs per primary. The secondary ribs bend forward and form a proconvex are at the rounded siphonal side. The whorl sides are slightly convex. The umbilical wall is high and vertical on the inner whorls and becomes rounded on the last whorl.

Age: Lothari Subchron of the Hypselocyclum Chron.

\subsubsection{Ataxioceras (Parataxioceras) cf. pseudoeffrenatum WEGELE 1929 Pl. 14, fig. 1 - text-fig. 59}

\section{Synonymy}

1961 Araxioceras (Paratnxioceras) pseudoeffrenatum WeGel.E - GEYER, p. 69, pl. 16, fig. 1, with synonymy 1992 Ataxioceras (Parataxioceras) pseudoeffrenatum WEGELE - FINKEL, p. 240, non fig. 9, figs. 17, 20

Material: MNHB J 31721

Locality: section RG 70, GYGI (1969, pl. 17). large quarry, Mellikon AG, bed 124, lower Baden Member.

$\begin{array}{llrl}\text { Description: Dimensions } & \mathrm{D} & 111 \mathrm{~mm} & \\ & \mathrm{Wh} & 37 \mathrm{~mm} & 33 \% \\ \mathrm{Wt} & 24 \mathrm{~mm} & 22 \% \\ \mathrm{U} & 46 \mathrm{~mm} & 41 \%\end{array}$

The carbonate internal mould is septate to a diameter of at least $78 \mathrm{~mm}$. The last half whorl is occupied by the body chamber. The primary ribs of the inner whorls begin at the umbilical suture line. They swing slightly back on the low and rounded umbilical wall. They are strongest at the umbilical margin. Their height and forward inclination varies already on the inner whorls. The forward inclination of the primary ribs is between $5^{\circ}$ and $15^{\circ}$. On the inner whorls the primaries split above half the whorl height into secondary ribs. On the last whorl the primary ribs begin to broaden already at the base of the convex whorl sides. The ribs there split irregularly into $6-8$ secondary ribs. On the phragmocone the secondaries bend slightly forward, but on the body chamber they are radial. The last whorl covers the preceding one by $36 \%$. The whorl section is high-oval.

Discussion: The figured specimen J 31721 is classed with reservation with the taxon pseudoeffrenatum WEGELE, because both the holotype of WEGELE (1929,pl.8, fig.5) and the specimen figured by GEYER (1961, pl. 16, fig. 1) are less densely ribbed and have a slightly narrower umbilicus.

Age: Hypselocyclum Chron.

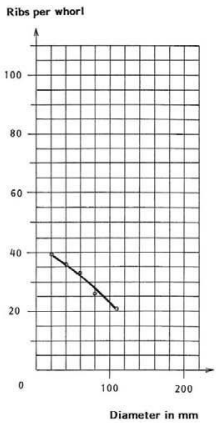

Fig. 59: Rib curve of Afaxioceras (Pararaxioceras) ef. pseudoeffrenatum WeGLLE MNHB I 31721.

Family Aulacostephanidae SPATH 1924

Subfamily Pictoniinae SPAтH 1924

Genus Ringsteadia SALFEL 1913

Type species: Ammonites pseudocordatus BLAKE \& HUDLESTON 1877

\subsubsection{Ringsteadia suebica n. sp.}

Pl. 12, fig. 1 - text-fig, 60

Holotype: MNHB J 31724, ex collection L. Rollier in the Geological Institute of the Eidgenössische Technische Hochschule (ETH) Zürich (see Gygi, 1969, p. 101). Original to pl. 12.fig.1.

Type locality: Dreifaltigkeitsberg above Gosheim near Spaichingen, southern Germany (Rollier's handwriting on the specimen).

Type horizon: To judge from the slightly glauconitic material of the internal mold, the specimen is from the Knollen Bed marker bed in the Villigen Formation.

Derivation of the name: from the Latin Suebia, a region in southern Germany.

Diagnosis: Large species of the genus Ringsteadia with a maximum diameter of the shell of about $400 \mathrm{~mm}$ and around $280 \mathrm{~mm}$ of the phragmocone. The primary ribs are strong and blunt. The secondary ribs fade away at the diameter of $220 \mathrm{~mm}$. 


\section{Ribs per whorl}

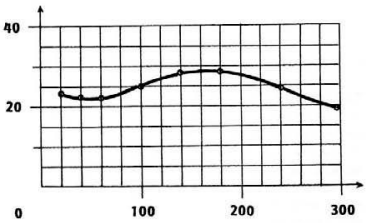

Diameter in $\mathrm{mm}$

Fig. 60: Rib curve of Ringsteadia suebica n.sp. MNHB J 31724. the northwest-european faunal province (see 5.6, the Oxfordian-Kimmeridgian boundary, below).

Subfamily Aulacostephaninae SPATH 1924

Genus Rasenia SALFELD 1913

Subgenus Eurasenia GEYER 1961

Subgeneric type species: Ammonites rolandi OPPEL 1863

\subsubsection{Rasenia (Eurasenia) trifurcata (REINECKE 1818) P1. 14, fig. 5}

Synonymy

1961 Rasenia (Eurasenia) trifurcata (REINECKE) - GEVER, p. 93, pl 1. fig. 7. pl.19. fig. 3, pl.22, fig, 4, with synonymy

Material: MNHB J 26452

Locality: section RG 70, Gral (1969, pl. 17), large quarry. Mellikon AG, bed 124, lower Baden Member.

$\begin{array}{llrl}\text { Description: Dimensions } & \text { D } & 120 \mathrm{~mm} & \\ & \text { Wh } & 43 \mathrm{~mm} & 36 \% \\ & \text { Wt } & 44 \mathrm{~mm} & 37 \% \\ & \text { U } & 46 \mathrm{~mm} & 38 \%\end{array}$

The slightly glauconitic, carbonate internal mould is septate to the body chamber. The strong, but blunt primary ribs begin at the umbilical suture line. The ribs are straight and have a forward inclination of $15^{\circ}$ at the diameter of $110 \mathrm{~mm}$. There are apparently three secondary ribs per primary rib. The secondary ribs disappear at the diameter of $220 \mathrm{~mm}$, from where the siphonal side becomes smooth. The whorl section is oval. The primary ribs are reduced to broad, low waves with striae on the body chamber.

Discussion: It is concluded from the whorl section, the slight inclination of the umbilical wall and the type of ribbing that the specimen J 31724 belongs to the genus Ringsteadia. The holotype of the new species may be compared with Ringsteadia anglica SALFELD no. 25502 that is kept in the collection of the Geological Survey of Great Britain at Keyworth, Nottingham, England (see SALFELD, 1917, pl.13). This English specimen is designated here as the lectotype of Ringsteadia anglica. The specimen MNHB J 31724 from Gosheim is not conspecific with R. anglica for the following reasons: It is somewhat larger, its phragmocone has a diameter of $282 \mathrm{~mm}$ as compared with $244 \mathrm{~mm}$ in the lectotype of $R$. anglica. Ringsteadia suebica has considerably thicker whorls than $R$. anglica. The siphonal side of $R$. suebica is rounded, not angular. The rib curves of the two taxa are similar (fig.60). Ringsteadia anglica SALFELD is the closest relative of Ringsteadia stiebica n.sp. in northwest-european Ringsieadiae,

Age: Latest Hauffianum Subchron of the Bimammatum Chron. This means that the genus Ringsteadia probably survived somewhat longer in the submediterranean faunal province than in
The glauconitic, carbonate internal mould is probably wholly septate. The primary ribs begin on the umbilical margin. There fore a horizontal straight line. The primary ribs are radial, high and sharp. Their maximum elevation is at one third of the whorl height. There they split into two strong secondary ribs. One. and in one casc, two secondaries are intercalated, so that there are generally three secondaries per primary rib. The secondary ribs are somewhat attenuated along the siphonal line. They lean a little forward. The whorl section is thick-oval (see GEYER, 1961, fig. 123 d).

Age: Hypselocyclum Chron.

Genus Sutneria ZITrEL 1884

Subgenus Sumeria ZITTEL 1884

\subsubsection{Sutneria (Sutneria) galar galar}

(OPPEL 1863)

Pl. 13, fig. 3

\section{Synonymy}

1961 Sutneria (Sumeria) galar (OPPEL) - GEYER, p. 132, pl.4, fig. 7, with synonymy

1977 Sutneria galar (OPPLL) - ZiEGLER, pl. 2, fig.3 are 16 primary ribs at all visible stages. The rib curve is there-

Subgeneric type species: Nautilus platynotus REINECKE 1818

1974 Sutneria gaiar (OPpEL) - BAnnuLescu, pl, 40, figs. 5 - 8 
1987 Sutneria galar (OPPEL) - ZiEgLER, pl.1, fig.2

1991 Sutneria (Sutneria) galar (Oppel) - Schl A Mpp, pl. 19, fig_1

1994 Sumeria (Sumeria) galar galar (OPPEL) - SchlEGEL.MIL CH, p. 112, pl.59, fig. 3

\section{Material: MNHB J 23622}

Locality: section RG 239, Grai (1990b, p. 69), excavation at Summerhalde, Schaffhausen, bed 18, base of Schwarzbach Formation.

$\begin{array}{llrl}\text { Description: Dimensions } & \text { D } & 26 \mathrm{~mm} & \\ & \text { Wh } & 11 \mathrm{~mm} & 42 \% \\ & \text { Wt } & 12 \mathrm{~mm} & 46 \% \\ & \text { U } & 6 \mathrm{~mm} & 23 \%\end{array}$

The slightly glauconitic carbonate internal mould is septate to the diameter of $16 \mathrm{~mm}$. The body chamber occupies two thirds of the last whorl. The peristome with lappets is preserved and indicates that the specimen is a complete adult. The primary ribs begin on the umbilical margin above the smooth and vertical umbilical wall. They split at one third of the whorl height into secondary ribs that bend back. The number of secondaries per primary rib increases from two on the phragmocone to four near the peristome. The secondary ribs are strong on the phragmocone and become faint towards the aperture. The body chamber has two abnormal bends so that it diverges from the normal coiling spiral.

Age: Galar Subchron of the Planula Chron.

\subsubsection{Sutneria (Sutneria) platynota (REINECKE 1818), morphotype A, SCHAIRER 1970 \\ Pl. 13, fig. 2}

\section{Synonymy}

1970 Sumeria (Sumeria) piatynota (Rinvecke), morphotype A SCHAIRER, p. 158, pl. 1, figs. 1-9, with synonymy

1977 Sutneria platynota (REINECKE) - ZiECiLER, pl. 3. fig, 3

1987 Sutneria piatynota (REINECKE) - ZiECLER, pl. 2, fig. 4

1991 Sumeria (Sumeria) platynota (RaINECKE) - SCHLAMp?. pl. 19. figs, $2-3$

1992 Suineria platynota (REINECKE) - FINKEL, fig. 83

1994 Sutheria (Sutneria) platynota (REINECKE) - SCHLEGELMLCh, p.112,pl.59, fig. 4

Material: MNHB J 23630

Locality; section RG 239. GrGI (1990b, p.69), excavation at Summerhalde. Schaffhausen, bed 22, lower Schwarzbach Formation.

Description: Dimensions D $20.0 \mathrm{~mm}$

$\begin{array}{lrr}\text { Wh } & 8.0 \mathrm{~mm} & 40 \% \\ \text { Wt } & 11.0 \mathrm{~mm} & 55 \% \\ \text { U } & 4.7 \mathrm{~mm} & 24 \%\end{array}$

The carbonate internal mould is septate to the diameter of $12 \mathrm{~mm}$. Two thirds of the last whorl are occupied by the complete body chamber. The peristome has narrow lappets. The specimen is a complete adult. The primary ribs begin on the umbilical margin and first swing back. On the whorl sides they become radial. On the phragmocone the primary ribs split at half the whorl height into two secondary ribs. The secondary ribs bend back. On the body chamber the primary ribs become coarser and continue to the siphonal margin. There they end in a tubercle. The secondary ribs fade away at the boundary between the phragmocone and the body chamber. The broad and only slightly convex siphonal side of the body chamber is thus smooth. The body chamber has two abnormal bends and diverges from the normal coiling spiral. The ornamentation ceases abruptly at the second abnormal bend.

Age: "Orthosphinctes" Subchron of the Platynota Chron.

Family Pachyceratidae Buckman 1918

Genus Protophites EBray 1860

Type species: Ammonites Christolii BeAudouin, 1851, designated by Rovan (1938, p. 209).

\subsubsection{Protophites chrisioli (Beaudounn 1851) Pl. 2, fig. 8}

\section{Synonymy}

1851 Ammonites Christolii-BeAudounn, p. 587, pl. 10, figs. 1-2

1900 Oecoptychius christoli BEAunouin - GEvREY, p. 45, pl . 2, figs. 1-9

1901 Oecoprychius Chrissoli Beaudoum - DE LORIOL, p. 20, pl. 1. lig. 13

1938 Christolia Christoli BEaudoun - Roman, p. 209, fig. 28

1951 Christolia Christoli BenudoIN-JeAnNet, p. 106, pl.31, figs, 7-10

1957 Protophites chrisfoli (BEAUdoun) - ARKELL et al.p. 296, figs. 355/2a-c

Material: MNHB J 24943

Locality: section RG 208, GyG (1977, pl.11, fig. 2), excavation on Brunnrain, Ueken AG, bed 9, upper Schellenbrucke Bed.

$\begin{array}{llrl}\text { Description: Dimensions } & \text { D } & 21 \mathrm{~mm} & \\ & \text { Wh } & 10 \mathrm{~mm} & 48 \% \\ & \text { Wt } & 13 \mathrm{~mm} & 62 \% \\ \text { U } & 3 \mathrm{~mm} & 14 \%\end{array}$

The iron oolitic, carbonate internal mould is a complete adult with rostrum and peristome. The phragmocone has a diameter of about $12 \mathrm{~mm}$. The greatest whorl thickness is at the end of the phragmocone. A sharp bend of the last whorl is located just before the end of the phragmocone. The body chamber occupies two thirds of the last whorl. There is a pronounced egression of the umbilical suture line of the body chamber. The primary ribs begin on the whorl sides near the umbilical margin and are strongest at the siphonal side. Secondary, intercalated 
ribs begin at about balf the whorl height. The peristome is relatively small.

Age: Late Cordatum Subchron of the Cordatum Chron.

Family Aspidoceratidae ZITtEL 1895

Subfamily Peltoceratinae SPATH 1924

Genus Gregoryceras SPATH 1924

Subgenus Pseudogregoryceras JEANNET 1951

Subgeneric type species: Pseudogregoryceras iteni JEANNET, designated by JEANNET (1951, p. 200).

\subsubsection{Gregoryceras (Pseudogregoryceras) iteni JEANNET 1951 \\ Pl. 2, fig. 11, pl 4 , fig. 5}

\section{Synonymy}

v1977 Gregorycenas (Pseudogregoryceras) ileni JEANNET - GYG, p. 46 . pl. 1. figs. $1-3$. pl. 10. figs. 1-2, with synonymy

Material: MNHB J 23048

Locality: section RG 209, GYGI (1977, pl.11, section 1), Herznach iron mine, Herznach $A G$, not in situ, collected from a block fallen from the Schellenbrucke Bed.

$\begin{array}{llll}\text { Description: Dimensions D } & 67 \mathrm{~mm} & \\ & \text { Wh } & 23 \mathrm{~mm} & 34 \% \\ \text { Wt } & 25 \mathrm{~mm} & 37 \% \\ \text { U } & 24 \mathrm{~mm} & 36 \%\end{array}$

The iron oolitic, carbonate internal mould is septate to the diameter of $45 \mathrm{~mm}$. The body chamber occupies two thirds of the last whorl. The innermost whorls have a circular cross-section. When the umbilicus attains a diameter of $6 \mathrm{~mm}$. the umbilical wall becomes vertical. Shortly afterwards an umbilical edge develops and the whorl sides become flat. There is a sharp edge at the siphonal margin on the last quarter whorl of the phragmoconc. This edge is diagnostic for the taxon. On the body chamber the whorl section is again circular (Grgr, 1977, pl. 10, fig. 1). The inner whorls are smooth. The first umbilical ribs appear at a diameter of $39 \mathrm{~mm}$ and bend back. Most of them split into two secondary ribs at the siphonal margin. The secondary ribs form a chevron at the rounded siphonal side where the siphonal margin is a sharp edge.

Age: Cordatum Subchron of the Cordatum Chron.
Subgenus Gregoryceras SPATH 1924

Subgeneric type species: Ammonites transversarius QUENSTEDT 1847.

\subsubsection{Gregoryceras (Gregoryceras) tenuisculptum GYG1 1977 Pl. 4, fig. 4}

Synonymy

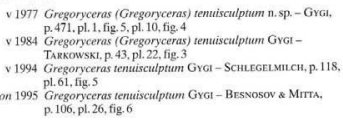

Material: MNHB J 23064, holotype

Locality: section RG 212, GyGI (1977, pl.11, fig.7), excavation above the shooting range in Churz Tal, Siblingen $\mathrm{SH}$, bed 7, Mumienmergel Bed.

$\begin{array}{llll}\text { Description: Dimensions } & \text { D } & 54.0 \mathrm{~mm} & \\ & \text { Wh } & 17.7 \mathrm{~mm} & 33 \% \\ & \text { Wt } & 21.5 \mathrm{~mm} & 40 \% \\ & \text { U } & 22.3 \mathrm{~mm} & 41 \%\end{array}$

The glauconitic, carbonate internal mould of the holotype is septate to a diameter of at least $68 \mathrm{~mm}$. The last two visible septal sutures are approximated. The specimen might then be the inner whorls of an adult with a diameter of about $85 \mathrm{~mm}$. The sides of the inner whorls are flat. The umbilical margin is an edge to the diameter of $25 \mathrm{~mm}$, then it becomes rounded. The umbilical wall is steep and high. The first umbilical ribs appear at the diameter of $23 \mathrm{~mm}$. This is diagnostic for the taxon. The ribs begin on the umbilical margin, have a strong backward inclination and an S-form curvature. Most of them split into two secondary ribs in the upper half of the whorl height. The secondary ribs are higher than the primaries and form a proconcave arc at the siphonal side.

Age: Densiplicatum Subchron of the Transversarium Chron.

\subsubsection{Gregoryceras (Gregoryceras) transversarium (QUENSTEDT 1847) Pl. 4, figs. 1-2}

\section{Synonymy}

v 1977 Gregoryceras (Gregoryceras) transversarium (QUENSTEDr) Gyol, p. 486, pl. 6, figs. 2-3, pl. 7, figs. 1-3, pl.8, figs. 1-2, pl. 10 , figs. $16-19$, with synonymy

1985 Gregoryceras transversaritm (QUENSTHDT) - SARTL, pl.2, fig. I 
v 1991 Gregoryceras transversarium (QUENSTEDT) - SCHLAMPP. pl.23. fig. 3

v 1991 Gregoryceras (Gregoryceras) transwersarium (QUENSTEDT) Gygi x von Hil irbrandt, p. 159, pl.6, fig. 1, pl.8, fig. 1

1994 Gregoryceras (Gregoryceras) cf rontani (DE Grossouvre) KraUTTEk, p. 329, fig. 4

v1994 Gregoryceras transversariam (QUENSTEET) - SCHLEGELMLCH, p. 119, pl. 62, fig. 2

Material: MNHB J 23051, J 28141

Locality of J 28141: Siblingen SH, Mumienkalk Bed.

Description of J 28141: Dimensions D $53.5 \mathrm{~mm}$

Wh $20.0 \mathrm{~mm} \quad 37 \%$

Wt $22.7 \mathrm{~mm} \quad 42 \%$

U $\quad 19.7 \mathrm{~mm} \quad 37 \%$

The glauconitic, carbonate internal mould is septate to the diameter of $63 \mathrm{~mm}$. The umbilical wall of the last whorl is high and steep. A pronounced umbilical edge separates the umbilical wall from the converging whorl sides. The primary ribs begin about half way up on the umbilical wall. They form strong tubercles at the umbilical edge. One or two straight ribs issue from the tubercles and lean thoroughly back. On the phragmocone some of these ribs split into secondaries at two thirds the whorl height. The ribs are attenuated in the middle of the whorl sides and again become strong at the siphonal margin. The whorl sides as measured above the ribs are therefore concave. The ribs are strongest at the slightly convex siphonal side.

Age: Antecedens to Luciaeformis Subchrons of the Transversarium Chron.

\subsubsection{Gregoryceras (Gregoryceras) riazi (DE Grossouvre 1917) \\ Pl. 4, fig. 3}

\section{Synonymy}

v 1977 Gregoryceras (Gregoryceras) riazi (DE Grossouvre) - GrGi, p. 473 , pl. 1, figs. $6-7$, pl. 2, figs. 1-5, pl.3, figs, 1-3, pl. 4, figs. 1-2.pl.5, figs $1-2$, pl. 10, figs. 5-11, with synonymy

1982 Gregoryceras riazi de Grossolvae - Drarand-PAssakd, pl. 12. fig. 3

v 1991 Gregoryceras (Gregoryceras) riazi (DE GrossouveE) - Grai a. VON HILLEBRANDT, p. 158, pl.3. fig. 8

1991 Gregoryceras riazi (DE GRossouvre) - SchLAMPP, pl. 23, fig. 2

v 1994 Gregoryceras riazi (DE Grossotvre) - SCHLEgEL MILCH. P. 118 pl. 61, fig, 6

Material: MNHB J 23062

Locality: section RG 230, GyG (1977, pl.11, fig.3), excavation north of Eisengraben, Gansingen AG, upper Birmenstorf Member.

$\begin{array}{llll}\text { Description: Dimensions } & \text { D } & 134 \mathrm{~mm} & \\ & \text { Wh } & 42 \mathrm{~mm} & 31 \% \\ \text { Wt } & - & - \\ \text { U } & 61 \mathrm{~mm} & 46 \%\end{array}$

The carbonate internal mould is septate to the diameter of $105 \mathrm{~mm}$. One half of the last whorl is occupied by the body chamber. The primary ribs begin in the upper part of the steep umbilical wall. They are enhanced at the umbilical margin in tubercles. On the inner whorls two primary ribs are often connected in a tubercle with an arc or an obtuse angle. The primary ribs bend back on the converging whorl sides Some of them split into two secondary ribs above half the whorl height. The ribs are attenuated in the middle of the whorl sides and become very strong at the flattened siphonal side.

Age: Antecedens to Luciaeformis Subchrons of the Transversarium Chron.

Subfamily Euaspidoceratinae SpATH 1931

Genus Euaspidoceras SPATH 1931

Type species: Ammonites perarmatus SOWERBY 1822.

\subsubsection{Euaspidoceras hypselum (OPPEL 1863)} Pl. 10, fig 1

Synonymy

1931 Aspidoceras hypselum Opret-Dors, p. 15, pl.1, figs, 9-11,pl.2. figs $3-4, \mathrm{pl}$. 3, figs, 1-2, with synonymy

1968 Chambites (Euaspitioceras) hypselum (Oppe) - Mn.1.5. pl. 7/8, fig. 8

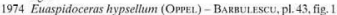

1979 Eraspidoceras hypselum (OPpEL)-SAPunov, p. 148, pl. 46, fig. 1. non $\mathrm{pl}$. 45, fig. 2. with synonymy

1991 Euaspidoceras (Euaspidoceras) hypsehum (OРPЕI) - SCHLAMpr, pl. 24 fig. 3

1994 Euaspidoceras hypselum (OpPLL) - ScHL.EGLL.Mich, p. 120, pl. 53. fig. 1

Material: MNHB J 27259

Locality: section RG 37, Gyol (1969,pl.17), Jakobsberg quarry. Auenstein $\mathrm{AG}$, not in situ, out of the limestone succession $55-80 \mathrm{ca} 70 \mathrm{~m}$ above the Gerstenhübel Beds, Effingen Member.

Description: The ill-preserved and diagenetically deformed specimen cannot be measured exactly. The diameter of the complete specimen must have been around $190 \mathrm{~mm}$. The last septum is at the diameter of $133 \mathrm{~mm}$. The last half whorl is occupied by the body chamber. The last ribs before the aperture are approximated and modified. The specimen is a near-complete adult. The whorls are thicker than high. The siphonal side secms to be more convex than that of OPPEL's type. The ribs begin on the rounded umbilical wall. On the umbilical margin they form a low tubercle. The ribs are attenuated in the middle of the whorl sides, then form a high, swollen tubercle at the siphonal margin. The tubercles carried thin, hollow spines.

Age: Hypselum Subchron of the Bimammatum Chron. 
Genus Epipelioceras SратH 1924

Type species: Ammoniles bimammatus QUENSTEUT 1858.

\subsubsection{Epipeltoceras bimammatum}

(QUENSTEDT 1858)

Pl. 10, fig. 4

Synonymy

1962 Epipeltoceras bimammatum (QUENSTEDI) - SIEFANov, p. 103 , pl. 2 , fig. 3

1962 Epipeloceras bimamnatum (QUENSIEDr) - SCHMIDT-KALER, p. 31 , pl. 3, fig. 1

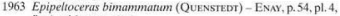
fig. 1 , with synonymy

1974 Epipeitoceras bimanmatum (QUENSTEDT) - BNRHULESCU, p. 137, pl. 42. figs. $4-8$, non 10

1977 Epipelloceras bimammatum (OUENSTEDr) - ZIEGL.FR, pl. 1, fie 6

1982 Epipeltoceras bimanmatum (QUENSIEDT) - DEBRAND-PASSARD. pl. 16, fig. 4

1987 Epipeitoceres bimammatum (OUENSnDT) - ZiEGLER,pl. 1. fig 3

1991 Epipelfoceres binamuatum (QUENSTEDT) - SCHLAMPP, pl. 1 , fig.s

1994 Epipeltoceros bimammatum (OUENSTEDT) - SCHLEGELMULCH. p. 68, pl. 23, fig. 10

Material: MNHB J 32268

Locality: section RG 76, GYal (1969, fig. 2), Hornbuck near Riedern am Sand, Erzingen D, bed 11, Hornbuck Member.

Description: Less than half of the specimen is preserved. There are two thirds of the body chamber that is deformed by compaction of the lime mud of the internal mould. Part of an inner whorl is flattened. The last ribs on the body chamber are approximated. The ammonite thus seems to be an adult. The ribs are very stout and widely spaced. The umbilicus is relatively narrow. The siphonal side is flat near the aperture and concave on the rear part of the body chamber.

Age: Bimammatum Subchron of the Bimammatum Chron.

\subsubsection{Epipeltoceras cf. bimammatum (QUENSTEDT 1858)}

PI. 10, fig. 5

Material: MNHB J 31726 ex collection C. Moesch, ETH Zürich no. Ve.S. 6686 .

Locality: section RG 35, detailed section unpublished, see GyGI (1969, pl. 19, upper section), Fahr quarry, Auenstein AG, bed 31 . Crenularis Member.

$\begin{array}{clll}\text { Description: Dimensions } & \text { D } & 49 \mathrm{~mm} & \\ \text { Wh } & 15 \mathrm{~mm} & 31 \% \\ & \text { Wi } & 14 \mathrm{~mm} & 29 \% \\ \text { U } & 20 \mathrm{~mm} & 41 \%\end{array}$

The glauconitic, carbonate internal mould is septate to the diameter of $35 \mathrm{~mm}$. The last three septa are approximated. The body chamber occupies the last half whorl and is complete. Part of the peristome and a lappet are preserved. There is a row of low tubercles along the umbilical margin. One and in two cases two ribs issue from these tubercles. The ribs are lowest in the middle of the almost flat whorl sides. The ribs end in tubercles on the siphonal margin. These tubercles are highest at the end of the phragmocone. At this stage the siphonal side is concave. Near the aperturc of this complete adult, the tubercles are low and the siphonal side is almost flat.

Discussion: The specimen described here has a wider umbilicus and more numerous and finer ribs than Epipeloceras bimammatum (QUENSTEDT). In this it resembles Epipeltoceras berrense (FAvRE, 1876, pl. 3, fig.11). This is the lectotype in the Museum of Natural History Bern as designated and refigured by SCHMIDI-KALER (1962, p.31, pl.3, fig. 4). However, the high and steep umbilical wall, the almost flat whorl sides and the high tubercles on the siphonal margin at the end of the phragmocone indicate that the specimen $\mathbf{J} 31726$ is an intermediate form between $E$. berrense and $E$. bimammatum, but that it is closer to Epipelfoceras bimammatum than to the stratigraphically older taxon.

Age: Early Bimammatum Subchron of the Bimammatum Chron.

Subfamily Aspidoceratinae ZrTtEL 1895

Genus Orthaspidoceras SРАтH 1925

Type species: Ammonites orthocera D'OrBIGNy 1847.

\subsubsection{Orthaspidoceras uhlandi (OPPEL 1863) Pl. 15, fig. 1}

Synonymy

1985 Orthaspidoceras uhlandi (OPPEL) - CHecA, p. 154, pl.31, fig.1. with synonymy

1991 Orthaspidoceras uhlandi (OPpEL) - SchL supp, pl. 25, fig. 6

1994 Orthaspidoceras uhlandi (OPPEL) - SCHLEgelMILCH. p. 130. pl.71. fig. 2

Material: MNHB J 22901.

Locality: section RG 70, GyGr (1969, pl.17), large quarry, Mellikon AG, beds above no. 126, lower Wettingen Member.

Description: Dimensions approximately D $209 \mathrm{~mm}$

Wh $84 \mathrm{~mm} 40 \%$

Wt $\quad 78 \mathrm{~mm} \quad 37 \%$

U $\quad 65 \mathrm{~mm} 31 \%$

The carbonate internal mould is septate to the diameter of $154 \mathrm{~mm}$. Half of the last whorl is occupied by the complete body chamber. Part of the peristome is preserved. The whorl section is thick-oval. The umbilical wall is well rounded and overhang- 
ing at the base. A single row of high tubercles is situated somewhat below half the whorl height. Three low, blunt ribs per tubercle begin at half the whorl height. These faint ribs are attenuated along the siphonal line.

Age: Later part of Divisum Chron.

\subsection{The vertical range of the taxa}

The vertical range of the stratigraphically significant ammonite taxa is indicated in fig. 61. About 8000 ammonites were available for this representation. Some of the vertical ranges as indicated in this figure do not agree with the ranges given by other authors. This is a consequence partly of the fact that the vertical ranges of taxa given in this paper are based on collecting from in situ, and partly because the vertical ranges may indeed vary in different parts of Europe. The distribution of ammonites in the succession is very uneven. Ammonites are abundant in the Herznach Formation and in the lowermost Renggeri Member in northwestern Switzerland. They are increasingly rare in the middle and upper Renggeri Member. In the Schellenbrucke Bed there is a profusion of well-preserved ammonites. The lowermost, condensed bed of the Birmenstorf Member (Densiplicatum and Antecedens Subzones) in Canton Aargau contains very few ammonites, but the coeval Mumienmergel and $\mathrm{Mu}$ mienkalk Beds of Canton Schaffhausen include an abundant ammonite fauna. Ammonites are fairly abundant in the normal facies of the Birmenstorf Member, but rare in the Effingen Member. The Villigen Formation too contains few ammonites except for the Crenularis and the Hornbuck Members. Ammonites are again abundant in the uppermost Villigen and in the lower Schwarzbach Formation.

Consequently, in many cases only single ammonite specimens of a given taxon were available in lithostratigraphical units with few fossils. Nevertheless, all the ammonite zones and subzones could be documented, but not always by their index as in the Grossouvrei and Hauffianum Subzones and in the Hypselocyclum Zone. Moreover, some ammonites found by private collectors not in situ have been used, if their origin could be concluded of the lithology of the internal mould (see captions to the plates). 


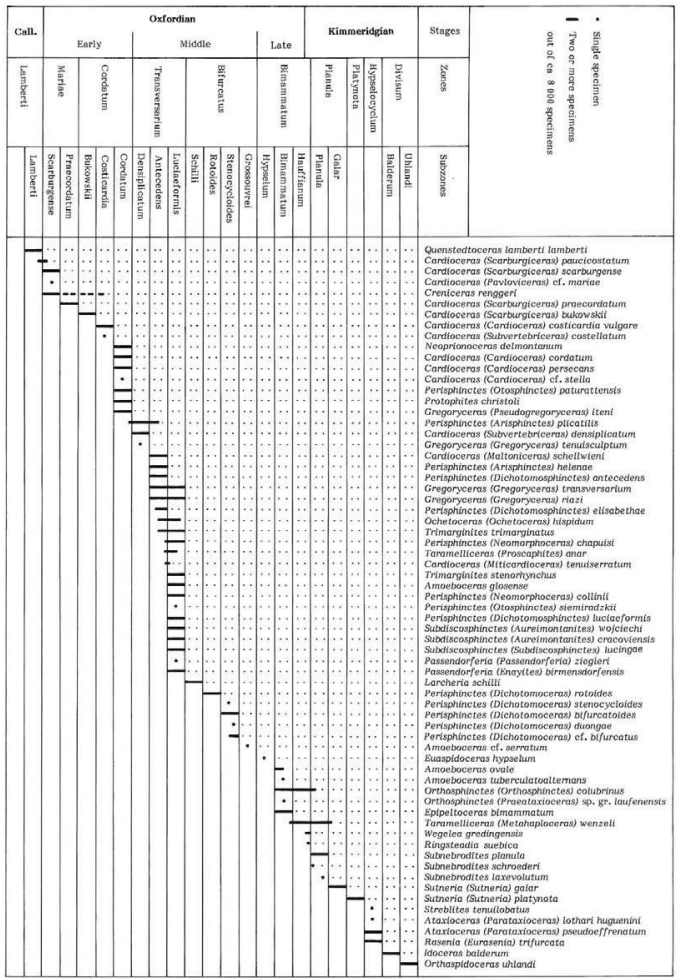

Fig. 61: The vertical range of stratigraphically significant ammonite taxa in northern Switzerland and in adjacent southern Germany. 


\subsection{The origin of lime mud}

The word mud is used here in the sense of PETTJOHN (1957, fig. 81 ) and means a mixture of unconsolidated clay-and siltsized particles with water. A large amount of lime mud sediment accumulated during the Oxfordian mainly in the basin. Clay- and silt-grade carbonate is a major constituent of the Bärschwil Formation. The greater part of the Effingen Member was originally lime mud (Gygt, 1969, pl.17, section 37), and the Villigen Formation is an almost pure lime mudstone with only small admixtures of clay minerals (GYGl, 1969. pl.17, section $62)$. In the Kimmeridgian very much lime mud has been sedimented both on the platform and in the basin. The main sources of lime mud are discussed in Sections 5.1.1 to 5.1.4.

\subsubsection{Bioerosion of hard substrates like reefs and limestone coasts in warm climates}

GYGI (1975. fig.11) found that fish of the genus Sparisoma and other reef fishes produce not only sand-size particles, but a large amount of mud. The erosion rate of Sparisoma viride (BONNATERRE) was calculated to be $17.4 \mathrm{~g} / \mathrm{m}^{2} /$ summer month on a reef in agitated water. Assuming a constant grazing activity the year round this amounts to $209 \mathrm{~g} / \mathrm{m}^{2} /$ year. More than half of this particulate carbonate is mud. Thus modern scarid fish are significant lime mud producers. Their closest functional relatives in the Jurassic are the pycnodontid reef fishes Mesodon and Microdon. GYGI $(1975$, p. 356) concluded that these were unimportant producers of ref-derived sediment, because their maxillar dentition did not grow again lifelong as in scarid fish.

According to HarTMan (1958), the boring sponge Cliona generates fine-grained silt. Txacex et al. (1948,p. 876) observed at Bikini in the Pacific that the bulk of boring organisms probably preferred protected environments in the atoll. This would reduce the chance of large-scale export of silt as generated by Cliona to the basin.

The surface covered by coral reefs and bioherms in the Late Jurassic of northern Switzerland was relatively small even at the time of their maximum extent in the middle Oxfordian. Coral reefs and bioherms were therefore probably only a minor source of lime mud. The mechanical erosion of Recent reefs by waves is thought to be insignificant (Scorfin et al. 1980, p. 502). Bioerosion of Recent reefs is much more important. It is caused in the tropical West Atlantic to a large extent by the graring regular sea urchin Diadema antillarum PHILIPPI. OGDEN (1977, p. 284) estimated an erosion rate of $4.6 \mathrm{~kg} / \mathrm{m}^{2} /$ year by this urchin on a patch reef on the northeast coast of St. Croix, U.S. Virgin Islands. The eroded carbonate is excreted in the form of pellets (SCOFFin et al. 1980, fig.6) that may disintegrate with time. Nothing is known of the constituent granulometry of these pellets that have a diameter of less than $1 \mathrm{~mm}$. Regular sea urchins are quite common in the lime-muddy sediment adjacent to lagoon reefs of the upper St-Ursanne Formation near St-Ursanne (WoLtersdork in PUMmPIN, 1965, p. 867), and they probably have produced carbonate sediment. However, Hunt (1969, p. 39) has found that the rock-boring regular sca urchin Echinometra lucunter on coral reefs of Bermuda produces but sand.

\subsubsection{Algae}

Recent marine calcareous algae like for instance Penicilluts secrete clay-size aragonite needles within their tissue (LoweNSTAM 1955, Cloud 1962). After the death of the algae the tissue decays and the aragonite needles are left as mud. LOWENSTAM \& Epstein (1957) and Neumann (1965) thought that such algae are major producers of lime mud.

\subsubsection{Nannoplankton}

Flógel \& Franz (1967, pl. 3, fig, 2, pl. 4, fig. 2) and Grgi (1969. text-fig. 1, pl. 4, fig. 16, pl. 5, fig. 17 and pl. 11,fig. 41) documented that coccoliths of the genus Watznaueria are a constituent of Oxfordian lime mudstones in northern Switzerland. GyGI (1969,p. 24) estimated that coccoliths comprise less than I\% of the rock volume even where they are most abundant in the upper Villigen Formation near Immendingen, southern Germany or in the Letzi Member near Mellikon AG. This may in part be due to recrystallization of the micrite. However, coccoliths and their micellae are well-preserved where they occur. Therefore it is unlikely that they formed primarily a major part of the lime mud in the Oxfordian in the deeper marine facies.

\subsubsection{Inorganically precipitated mud}

There is growing evidence that much or most of the carbonate, mostly aragonitic, mud sedimented on the Great Bahama Bank is precipitated inorganically as has been concluded by CLOLD in a careful study as early as 1962 . KINSMAN $(1969$, p. 498) cautioned that there is a difference in the $\mathrm{Sr}^{+2}$ content between lagoonal carbonate mud and oolite sand in the Persian Gulf on the one hand and the $\mathrm{Sr}^{+2}$ content predicted for "simple inorganic precipitation" from sea water on the other hand. SHINN et al. (1989) found that whitings on the Great Bahama Bank produced great quantities of aragonitic sediment. The authors concluded from carbon and oxygen-isotopic analyses that the suspended sediment in whitings contains chemically precipitated calcium carbonate. MACINTYRE \& REID (1992, figs. 1 A-F and 2) showed that aragonite needles precipitated in whitings had a different shape than needles secreted by algae. RoBBins \& BLACKWELDER (1992, p. 464) gave evidence that cells of pi- 
coplankton and degrading organic cellular components trigger the precipitation of clay-size carbonate crystals from supersaturated sea water in whitings on the Bahama platform. On p. 468 they drew attention to the abundant micrite in Proterozoic and lower Palcozoic strata for which formation by the degradation of skeleton-forming invertebrates and macroalgae may be rulcd out.

It is concluded from the papers cited above that inorganic precipitation of calcium carbonate initiated by plankton is quantitatively the most important source of lime mud in tropical and subtropical shallow water environments and may well have been the most important source of lime mud during the Oxfordian and Kimmeridgian Ages in northern Switzerland.

\subsection{Synsedimentary tectonics}

\subsubsection{Regional, endogenic subsidence}

Northern Switzerland was in the Late Jurassic near the northern margin of the Tethys ocean (fig. 2 and ZiEGLER 1988. pl. 13) that was undergoing active extension related to sea-floor spreading at the time. The whole area subsided on the average at an equable rate (BücHi et al. 1965, p. 33 and fig. 16, see also WiLD et at. 1989) that was probably related to the sea-floor spreading of Tethys,

\subsubsection{Smaller-scale differential subsidence}

It is evident from the paleogeographic maps by GyGr (1990e, mainly figs 5 and 6 ) that there must have been block faulting at a smaller regional scale, but no clear fracture pattern is apparent from the maps.

\subsubsection{Local tectonism}

Minor synsedimentary fractures may be seen in the field. GYG1 * Persoz (1986) have figured two examples: on fig. 2 a small subvertical fracture is visible at the lower right hand side of the picture. The amount of displacement dimishes upwards and then finally disappears in the middle of the photograph. Another fracture is in the middle of fig. 8. The thickness of two lime mudstone beds to the right (south) of the fracture increases wedge-like towards the fault. A synsedimentary fault must be present ca. $10 \mathrm{~m}$ east of section RG 406 near Vermes JU, adjacent to bed 20 (not shown in $\mathrm{pl} .37$ ) judging from the breceia shown in fig 62 that is interpreted to be a fault breccia.

\subsubsection{Exogenic subsidence}

ZIEGLER (1982, p. 106) reported that a thickness of $3000 \mathrm{~m}$ of sediments can accumulate in a basin with an initial depth of $1000 \mathrm{~m}$. Grar (1986,p. 472) confirmed this at the smaller scale of the Rhodano-Swabian epicontinental basin by calculations The basement then subsided under the load of sediments by two

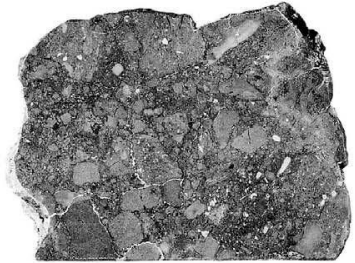

Fig. 62: Presumed fault breccia in the Günsberg Formation, section RG 406 . Vermes JU, ravine southeast of La Kohlberg farm, ca $10 \mathrm{~m}$ to the east of the creek at an elevation of about $740 \mathrm{~m}$. Sample Gy 4915. Scale $x 0.48$.

thirds the compacted thickness of the sediments GYar (1986) illustrated this effect in his figures $3 \mathrm{~A}, \mathrm{~B}$ and $\mathrm{C}$. The differential, exogenic basement subsidence was caused by the shifting of the depocenters of three consecutive shallowing-upward successions during the Oxfordian.

\subsection{Eustatic sea-level changes}

Several authors (HALLAM 1978, fig. 11, HaQ ef al. 1987 and SAHAGIAN \& JONES 1993, fig. 3) agree that a net eustatic sea level rise occurred in the Oxfordian Age. Gyol (1986) compared the vertical transition from oolite to carbonate mud with coral bioherms in the middle St-Ursanne Formation near St-Ursanne with other sections in Europe of the same age (Late Antecedens Subchron), He concluded from his calculations of subsidence that there must be an eustatic component in the relative sealevel rise that caused this vertical facies change. He attempted to quantify the eustatic sea-level rise of the Antecedens Subchron by comparing the lagoonal upper St-Ursanne Formation with its coral bioherms with the Recent lagoon of the Bermuda atoll. He arrived at a minimum of $7 \mathrm{~m}$ of this individual sea-level rise and at a total of $25-30 \mathrm{~m}$ of eustatic sea-level rise for the whole $\mathrm{Ox}$ fordian. This is of course only a coarse estimate. SAHAgian \& JoNes (1993, fig. 3) calculated an custatic sea-level rise above the stable Russian Platform of only a few meters during the Oxfordian Age. Both long and short term variations in relative sealevel are discussed in GYGi et al. (1998).

\subsection{Depositional sequences}

The depositional sequences in the sense of $\mathrm{V}_{\text {AIL }}$ that can be discerned in the Late Jurassic of northern Switzerland are described and discussed in Gygr et al. (1998). The sequence boundaries as discerned in that paper are indicated in this work in fig. 40 and in plates $16-44$ 


\subsection{Biochronology: ammonite zones and subzones}

A range chart of the figured ammonites is given in fig 61 .

\subsubsection{The lower boundary of the Oxfordian Stage}

The Colloque du Jurassique Luxembourg 1962 recommended that the Late Jurassic Epoch should begin with the Oxfordian Age. The lower boundary of the Oxfordian Stage has been established by the same international congress to be the base of the Quenstedtoceras mariae Zone: Colloour. Du JuRassioue LUXEMrourg $1962(1964, p .85)$. The base of this zone is equivalent to the lower boundary of the Scarburgense Subzone (see ARKELL 1941, p. 170). No stratigraphically complete section of this boundary with ammonites has been published from Central Europe so far. A thick, probably complete section near Thuoux in the Terres Noires of the Dauphinois basin in southeastern France has been proposed by ForTwENGLER \& MARCHAND (1994. p. 103) as boundary type section (ca. $100 \mathrm{~km}$ southeast of Valence in the Rhône valley).

\subsubsection{Mariae and Cordatum Zones}

The first two zones of the Oxfordian, the Mariae and the Cordatum Zones, can be documented with all their subzones in northern Switzerland (see this paper, pls.1-2). They are adopted here according to CALLOMON $(1964$, tab. 2$)$.

\subsubsection{Transversarium Zone}

A Transversarium Zone sensu lato has been proposed by OpPEL (1863. p. 165). OPPEL stated that "the proper region of Amm. transversarius" was the Birmenstorf Member that had been defined in the same year by Morsch (1863, p. 160) in Canton Aargau. OpPel wrote in OpPeI \& WAagen $(1866$, p. 244) that the type locality of the Transversarium Zone was at Birmensdorf near Baden in Canton Aargau. This village is today spelled Birmenstorf (and should not be confused with Birmensdorf in Canton Zürich). Grar (1977,fig. 2) has mapped the vineyards of the locality called Nettel northeast of Birmenstorf at the scale of 1:5000 and found no indication that an outcrop of the Birmenstorf Member ever existed there. For this reason, GyGI (1969, p. 64) has proposed the fossiliferous section RG 60 in the Eisengraben cleft near Gansingen $A G$ as type section of the Birmenstorf Member. The excavations RG 210 and RG 225 in the Eisengraben and the excavation RG 230 north of Eisengraben (GYGi, 1977, pl.11) provide a composite reference section of the Transversarium Zone (GYGI, 1977, p. 517) in the sense of HEDBERG (1976, p. 58).

OPPEL \& WAageN $(1866, \mathrm{p} .245)$ indicated that the Transversarium Zone begins in Canton Aargau above the "iron ore with Amm. Lamberti and cordatus". Gygt (1977, p. 454) named this characteristic bed Schellenbrücke Bed. Grgi \& Marchand (1982) figured a rich fauna of cardioceratid ammonites from this bed and fixed its age to be of the Cordatum Subchron. The lowermost bed of the Birmenstorf Member in Canton Aargau. by definition the lowermost bed of the Transversarium Zone, contains near Herznach Cardioceras (Plasmatoceras) ienuistriatum BorsssJak and Cardioceras (Subvertebriceras) aff. zenaidae ILovalskr in ArKeLL as figured by GrGI \& Marchand (1982, pl. 12, figs. 2 and 3). Both of these taxa are indicative of the Densiplicatum Subzone that was introduced by GYGl (1991, fig. 8). Perisphinctes (Dichotomosphinctes) antecedens SALFELD, the index of the following subzone, occurs in the same bed. Ammonites are rare in the lowermost bed of the Birmenstorf Member in Canton Aargau, but the coeval Mumienmergel and Mumienkalk Beds (fig.40) of the adjacent Klettgau valley and Randen Mts, contain a rich ammonite fauna that has been listed by Grat $(1977$, tab. 1). OpPel \& WAAGEN $(1866$, p. 241$)$ stated that at the (western) slope of Mt. Eichberg near Blumberg in southern Germany these thin beds contain "Ammonites plicatilis Sow.". Indeed, Fischer \& Grol (1989, fig.4D) proved that Perisphinctes (Arisphinctes) plicatilis (SOWERBy) occurs in the Mumienmergel Bed near Gächlingen SH in the Randen Mts. not far south of Blumberg. This is evidence that "Ammonites plicatilis Sow." in OPPEL \& WAAGEN (1866, p. 241) is not based on a misidentification. The bases of the Transversarium and of the Plicatilis Zones are then coeval as ARKELL $(1956$, tab, 10) concluded. The Transversarium Zone has been introduced by OpPEL in 1863 and has priority on the Plicatilis Zone that was only published in 1878 .

The view that the Transversarium Zone and the Plicatilis Zone were about time-equivalent as held by ARKELL (1956, tab. 10) has been challenged by CALLOMON (1964, p. 284 and tab. 2). Callomon included the Parandieri Subzone in the Plicatilis Zone and thought that the Transversarium Zone suceeeded his Plicatilis Zone. Enay (1966, p. 263) decided that the Parandieri Subzone of CALLONON (1960, p. 197) was the lower part of the Transversarium Zone. Cariou et al. in Mouterde et al. (1971, p. 93) therefore restricted the Plicatilis Zone in France to the Tenuicostatum (or Vertebrale) Subzone and the Antecedens Subzone which is followed by an amputated Transversarium Zone. All the French authors have agreed with this ever since. But this practice is untenable for the sake of stability in stratigraphic nomenclature, at least in Central Europe, if not worldwide, because Perisphinctes (Arisphinctes) plicatilis (SowERBY) has a much smaller geographical range than Gregoryceras (Gregoryceras) transversarium (QUENSTEDT) that has been found not only in Central Europe, but also in the Tethyan realm and as far away as northern Chile in the southern hemisphere (Gygl \& von Hillebrandt 1991, pl. 8, fig. 1). The Plicatilis Zone should therefore only be used in southern England, northern France and northern Germany.

\subsubsection{Densiplicatum Subzone}

Chiefly the following names have been proposed for this time interval:

- Tenuicostatum Beds SALfeld (1913, tab. 1)

- Vertebrale Subzone AkKeli. (1947,p. 98)

- Densiplicatum Subzone GyGl (1991b, p. 12 and fig. 8).

The Tenuicostatum Subzone has never gained wide acceptance. The Vertebrale Subzone is commonly used as for instance by 
Carsou et al. (1991a). The zonal index occurs probably only in England and in the Baltic and is thus unsuitable for Central Europe. A Densiplicatum Zone has been introduced by Srkes \& CALlomon (1979, p.845). The index, Cardioceras (Subveriebriceras) densiplicatum BoDEN, is recorded from the Baltic: BoDEN (1911, pl.1, fig. 14), from England: ARKELL (1942, pl.52, fig. 4), from southern France: Boursead (1977, pl.8, figs 5 and 10). and from Switzerland: GYGI \& MARCHAND (1982, pl.11, figs. 5 and 6 ). The Densiplicatum Subzone, this is to say the biozone of Cardioceras (Subvertebriceras) densiplicarum BODEN, appears to be best suited for Central Europe. It is here defined to be restricted to the vertical range of the index and does not include the Maltonense Subzone as was proposed by SYKES \& CALLOMON (1979, p.848).

\subsubsection{Antecedens Subzone}

The Antecedens Subzone as proposed by ArKeLL (1947, p.98) is now widely used and is adopted here in its original sense.

\subsubsection{Luciaeformis Subzone}

The interval between the Antecedens and the Schilli Subzones has been called Parandieri Subzone by TiNTaNt (1958, p. 2505). It is named after Perisphinctes (Perisphinctes) parandieri DE LORIOL. Only a few complete specimens of this very large taxon are known (see ENAY 1966). No complete adult of it has ever been found in Switzerland. A substitute must therefore be found. Perisphincles (Dichotomosphinctes) luciaeformis ENAY is best suited for this, because its vertical range in northern Switzerland fits exactly into the interval between the Antecedens and the Schilli Subzones. The taxon has already been suggested as a subzonal index by MELENDEz (1989, fig. 22). It has a medium size with a maximum diameter around $150 \mathrm{~mm}$. Near-complete specimens that can be readily identified are there-fore casier to find than representatives of Perisphinctes (Perisphinctes) parandieri. The oldest Perisphinctes (Dichotomosphincles) luciaeformis in the collection of the Muscum of Natural History Basel is specimen J 24532 that has been found in the excavation RG $81 \mathrm{~b}$, bed $14 \mathrm{a}$, lower Mumienkalk Bed, near Gächlingen SH. Among the youngest representatives is specimen J 24157, complete with peristome and lappets, from the upper Birmenstorf Member in excavation RG.230 north of Eisengraben near Gansingen, Canton Aargau. Another specimen, from the condensed glauconitic marl at the base of the Effingen Member in Canton Schaffhausen, has been figured by Fischer \& GyGt (1989, fig. 6D) and is refigured in this paper, pl. 5 , fig. 4 .

\subsubsection{Bifurcatus Zone}

The Bifurcatus Zone was originally suggested by Boone in PETrTCLERC (1922, p.9), but was formally introduced independently by EnaY (1964, p. 494). The Schilli Subzone as proposed by BoOne in Petrtclerc (1922, p. 9) and Cariou (1966, p. 49) is taken by Gra (1991b, fig. 8) as the lowest subzone of the Bifurcatus Zone, because the index, Larcheria schilli (OPPEL), occurs in Canton Aargau above the Birmenstorf Member, and because Gregoryceras s. str. disappear below the base of the Schilli Sub- zone (GYGl, 1977, tab. 1). Provided that the Luciaeformis Subzone can really be discerned from the Parandieri Subzone in the upper Transversarium Zone, the Transversarium Zone would have four subzones. The Transversarium and the Bifurcatus Zones are then about equal in duration if the Schilli Subzone is included in the Bifurcatus Zone. But this is an arbitrary delineation, because the Dicholomoceras taxa typical of the Bifurcatus Zone first occur only in the Rotoides Subzone of CARIOU \& MELEndez (1990, p. 144). The Stenocycloides Subzone of CARIOU et al. (1991) is well-documented in northern Switzerland, but the index of the Grossouvrei Subzone has not been found to date.

\subsubsection{Bimammatum Zone}

The Bimammatum Zone was introduced by OppeL (1863, p. 175). Cariovet al in Mouterde et al. (1971) have subdivided it into the Hypselum, the Bimammatum and the Hauffianum Subzones. The Hypselum Subzone of Dorn (1930, p. 115) is documented by the index in northern Switzerland (pl.10, fig.1). The index of the Bimammatum Subzone is figured on pl.10, fig. 4 and has been found in the Hornbuck Member. There are no ammonites diagnostic of a subzone in the Kussaburg Member above. Subnebrodites of the Planula Zone first appear at the base of the Wangental Member. The Küssaburg Member is therefore tentatively assigned to the Hauffianum Subzone although Gyal (1969, tab. 8) thought it belonged to the Planula Zone. This was based on the small perisphinctid MNHB J 31717 of the Küssaburg Member from Beggingen SH that had been identified as Idoceras mimufum DiETERICH.

\subsubsection{Planula and higher Zones}

The Planula to the Divisum Zones are interpreted according to MOUTERDE et al. (1971).

\subsection{The boundary between the Oxfordian and the Kimmeridgian Stages}

The Oxfordian-Kimmeridgian boundary is difficult to correlate between the type area in southern England and Central Europe because of a pronounced provincialism in ammonites. MOESCH (1867, p. 175) drew the boundary at the base of the Letzi Member in Canton Aargau, this is to say at the base of the Planula Zone. Heim (1919, table opposite p. 506), based on unpublished tables by RoLLIER, placed the boundary in northern Switzerland within his Reineckianus Beds (the Platynota Zone). In the following decades a consensus developed between French, Swiss, German and Polish authors to fix the boundary at the base of the Platynota Zone: Mouterde et al. (1971), Gyor (1969, tab. 1). ZEISs (1965, p. 91). WierZBowska (1965, tab. 2).

This traditional correlation was questioned for the first time by ZiEGLER (1964, p. 351). Morkis (1968, p. 102) thought that the Oxfordian-Kimmeridgian boundary was in the Jura and in Swabia in the uppermost Bimammatum Zone. SYKes \& CAL- 
LOMON (1979, p. 894) concluded that most if not all of the Planula Zone must be assigned to the Kimmeridgian. WIERZBowsK (1991, tab. 1) was of the same opinion (see also ATrops et al. 1993, fig.3). Schweigert (1995, p. 176) has recently collected ammonites from in situ at Hundsracken near Balingen, southern Germany. He confirmed the statements by OPPEL ( 1863 , p. 201, 212) that Amoeboceras bauhini (OPPEL) and Taramelliceras hauffiamum (OPPEL) occur together and introduced the Bauhini faunal horizon. The Bauhini Subzone has been introduced by SYKES \& CALLOMON (1979, p. 843) as the uppermost subzone of the boreal Oxfordian.

Schweigert \& Callomon (1997, fig. 9, p. 43) are now of the opinion that Amoeboceras bauhini (OPPEL) occurs at the base of the Kimmeridgian Stage in Great Britain, the type area of the Kimmeridgian. They indicated (1997, fig. 7 and p.33) that the Bauhini Horizon was glauconitic at many localities in southern Germany. Groi (1969, p. 57) stated that his glauconitic marker bed of the Knollen Bed could be followed from northern Switzerland into southern Germany at least as far as the region of Balingen. It is then possible that the Knollen Bed and the Bauhini Horizon are coeval. This cannot be decided until more ammonites will be collected from the Knollen Bed. Ringsteadia suebica $\mathrm{n}$. sp. has been found almost certainly in the Knollen Bed. According to a personal information by J. Callomon of 29/8/1996, the vertical range of Ringsteadia does not extend into the Kimmeridgian in England. There is the possibility that the genus Ringsteadia survived somewhat longer in Central Europe than in England, or that Ringsieadia suebica n.sp. is not a true Ringsteadia. For the time being it is presumed that the Knollen Bed is the earliest lithostratigraphic unit of the Kimmeridgian in northern Switzerland.

The Knollen Bed marker bed has the disadvantage that it is not mappable at the scale of $1: 25000$. It can only be recognized in good sections. The Oxfordian-Kimmeridgian boundary as defined as the lower boundary of the Knollen Bed can only be recognized where this marker bed exists. Near Balsthal or Porrentruy the new Oxfordian-Kimmeridgian boundary cannot be indicated for lack of biostratigraphic or lithostratigraphic evidence.

\subsection{Radiochronology}

A first attempt to date Oxfordian sediments in northern Switzerland radiometrically was made by GrG1 \& McDoweLL (1970). A detailed correlation of biostratigraphic subzones as documented by figured ammonites with revised numeric ages was published by FISCHER \& GrGi (1989). These numeric ages are based on $\mathrm{K}$-Ar radiometric dates from authigenic glauconites with a relatively low potassium content and consequently a not very well-ordered crystal lattice (Gygi \& MCDowell , 1970, fig. $3 \mathrm{~A}$ and tab. 1). This may have reduced argon retention.

GradsteIN et al. (1995) recently published the first Mesozoic time scale using an integration of radiometric ages and magnetochronologic data of basalt on the ocean floor with data from sediments on land. Their estimate of $159.4 \pm 3.6 \mathrm{~m}$.a. for the
Callovian/Oxfordian boundary indicates that the age of 149.2 m.a. for the Cordatum Subchron by Fischer \& GyGI (1989) is too young.

\subsection{Magnetochronology}

The whole of the Oxfordian in non-condensed mud facies and the lower Kimmeridgian sediments of northern Switzerland have been sampled and analysed in order to establish a magnetochronology by J.G. Ogg in 1987. Unforunately, the magnetic signatures were ambiguous and no results were obtained.

\subsection{Correlation}

A number of marker beds made precise lithostratigraphic correlations possible. These are: the condensed bed at the base of the Birmenstorf Member and the Mumienmergel/Mumienkalk Beds, the Hauptmumienbank Member, the Crenularis Member, the Knollen Bed, the lower boundary of the Reuchenette Formation, the Banne Member, the Virgula Member and the glauconitic marker bed in the Felsenkalk Formation.

Ammonites proved to be the best means of biostratigraphic correlation although they may be rare even in the basin, for instance in the upper Renggeri Member and in the middle and upper Effingen Member. A.mmonites are so rare in the shallow water realm that they are insufficient for detailed biostratigraphic correlations there.

Clay minerals, especially kaolinite, made detailed correlations possible in the shallow water realm, mainly in rocks where ammonites are absent. The vertical variation in the kaolinite content has first been calibrated in the basin with ammonites and then correlated into the shallow water rocks. These correlations could be checked and confirmed by a number of ammonites from shallow water sediments (GrGi, 1995).

Sequence stratigraphic analysis of the Oxfordian and Kimmeridgian strata in northwest Switzerland corroborates the correlations arrived at by the methods mentioned above, and if one assumes that key sequence stratigraphic surfaces are isochronous they improve the correlation further. Preliminary comparison of the Upper Jurassic sequence statigraphic surfaces in England (COE, 1992, 1995) with those in Switzerland shows remarkable similarity (COE \& GyGt, 1994).

\subsection{Palaeogeography and history of sedimentation}

Palaeogeographic maps of the Late Jurassic in northern Switzerland were published by GYGr (1990c).

The sedimentation of the Late Jurassic in northern Switzerland began in an epicontinental sea north of the Tethys. The initial water depth was about $60 \mathrm{~m}$ in the northwest and $100 \mathrm{~m}$ in the cast. The land of the Ardenne and of the Rhenan Massifs to the northwest (figs, 2 and 63) mainly supplied siliciclastic sediment to the epicontinental basin. The sediment supply varied widely as a function of eustatic sea-level fluctuations and of cli- 
mate. The climate was seasonal and varied between humid and relatively dry. A submarine bank of argillaceous prodelta mud built out southeastward from the landmass in early to middle Oxfordian time (early Transversatium Chron). This is the Bärschwil Formation. The formation thins drastically towards the basin (fig. 39). The time-equivalent sediments in the basin are thin beds of iron oolite and glauconitic marl-clay with carbonate nodules.

The supply of terrigenous sediment ceased almost com. pletely in the later Transversarium Chron, probably because the climate became drier. The carbonate platform of the St-Ursanne Formation evolved on top of the argillacious mud bank of the Barschwil Formation. This platform was rimmed by oolite shoals A belt of coral bioherms fringed the platform in somewhat deeper water. In the thin, time equivalent basinal sediments of the Birmenstorf Member grew thickly colonized biostromes of siliceous sponges. These contain a rich ammonite fauna.

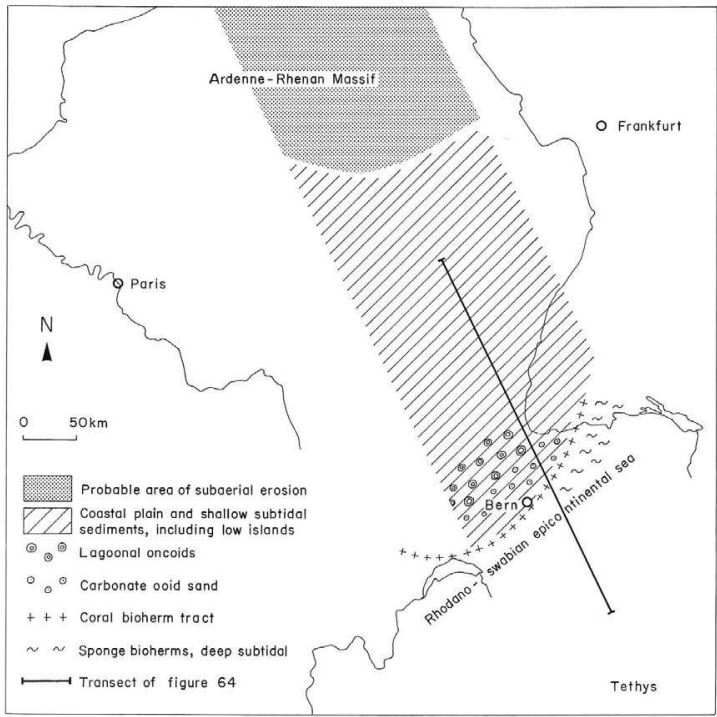

Fig.63: Palaeogeographical map of Central Europe in the late Oxfordian (early Bimammatum Subehron). The bank of Late Jurassic shallow. water sediments in northwestern Switzerland (late Burgundy platform, now part of the folded Jura Mountains) was probably contiguous to the land of the Ardenne-Rhenan Massif as indicated by the large dinosaur that was found in the lowermost Reuchenette Formation of northern Switzerland near Moutier (GrepPIN 1870). The position of the coastline cannot be indicated because of the erosion of Mesozoic sediments above the Vosges horst. The Tethys serssu lato (now: Alps) includes the southem passive margin of Europe from the ultrahelvetic facies belt to the deep penninie basin (STAMPFu 1993, fig, 11). Refigured from GyGt (1992, fig. 1). 
$\leftarrow$ Land

Carbonate/argillaceous bank

\title{
Epicontinental basin
}

\author{
Celtic (partially Rourocian) \\ facies belt
}
(partially Argovian)
facies belt

Rhodano-swabion

Helvetic facies belt
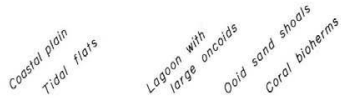

Deeper marine carbonate and
orgilloceous mud with
slliceous sponges and ammonites
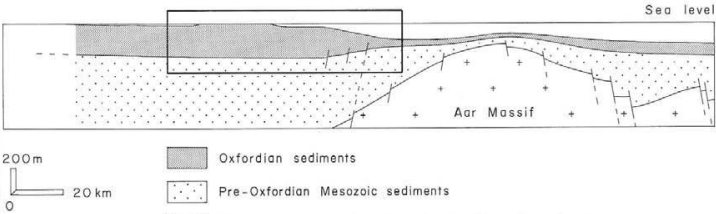

Oxfordian sediments

$\therefore$ Pre-Oxfordion Mesozoic sediments

Variscan basement, locally with Late Paleozolc sediments

Fig.64: Schematic cross-section through the epieontinental sea north of the Fethys in the Late Oxfordian (early Bimammatum Subchron). By this time, much of the epicontinental basin was filled up with terrigenous sediment and carbonates that prograded to the south-southeast. PostVariscan rifts in the igneous and metamorphic basement that are filled with thick Pcrmo-Carboniferous sediments are not shown. Detailed crosssection in inset is shown in fig. 39. Refigured from Grar (1992. fig. 2).

A strong terrigenous sediment supply from the northwest resumed in the Bifurcatus Chron. The carbonate platform shrank to the narrow band of the Günsberg Formation at that time. Initially, carbonate mud could settle on the inner platform (Vorbourg Member) while large quantities of argillaceous mud passed over the platform. The argillaceous Ruschenz Member was then sedimented over the shallow inner bank, and the Effingen Member in the basin. In the early Hypselum Subchron the relative sea-level probably dropped and caused repeated and widespread emersion on the bank (sequence boundary O6). Coastal swamps with peat (now: coaly layers) and freshwater ponds with characean algae and limnic ostracods were formed.

A transgression followed in the later Hypselum Subchron that brought back growth of coral bioherms and oolite shoals to the inner platform. Then the climate grew drier, the terrigenous sediment supply dropped sharply, and another, thin carbonate platform developed. The Hauptmumienbank algal ball sediment was laid down over the inner platform while the oolite shoals of the Steinebach Member and a fringe of coral bioherms were formed at the platform margin.

After another short episode of argillaceous sediment supply (Bure Member) the growth of a widespread carbonate platform resumed (Holzflue and Verena Members). The fringe of coral bioherms reached its maximum progradation at this time. In the earliest Kimmeridgian the coral bioherms beyond the rim of the platform died. Later in the Kimmeridgian the platform shrank somewhat. Coral bioherms reappeared at the platform margin in about the Hypselocyclum Chron near Balsthal. 


\section{Acknowledgments}

The fossil excavations were funded by the Schweizerischer $\mathrm{Na}$ tionalfonds, grant no. 2.211.69, the Freiwillige Akademische Gesellschaft Basel, the Holderbank-Stiftung and the Stiftung für wissenschaftliche, systematische Forschungen auf dem Gebiet des Beton- und Eisenbetonbaues. Grant no. 2.165.78 by the Schweizerischer Nationalfonds made the measuring of sections in the central Jura possible. Thanks are due to the authorities of townships, companies and private persons who gave permission to excavate and measure sections on their land and in their quarries. The Holderbank and the Vigier cement companies as well as the Schweizerische Sodafabrik Zurzach gave assistance in excavating ammonites from their quarries.

Sylvia Gygi, my wife, has found and prepared a great part of the ammonites figured in this paper. The book would not be as well documented without her generous help. K. Müller and A. Heite prepared the thin sections and the polished slabs. $\mathrm{S}$. Dahint made most of the photographs. The drawing of the sections in ink has been made possible by the funding of B.M.
Gygi, my mother. I wish to thank the great number of other persons who bave helped me in many ways, especially J.H. Callomon, E. Cariou, E. Mönnig. H. Rieber and A. Wetzel. S. Gygi typed the manuscript and prepared the final version of fig. 61 .

Special thanks are due to A. L. Coe who reviewed the entire manuscript, improved the English and made many helpful suggestions. R. Enay reviewed the palaeontological part of the paper and gave valuable comments. The palaeontological part of the paper was also reviewed by A. Zeiss who made some remarks. H. Funk and B. Schwizer carefully reviewed the paper except the biostratigraphic part and made some suggestions.

The major part of the printing costs were covered by the Commission on the Memoirs of the Swiss Academy of Sciences, the rest by the governments of the Cantons Jura, Baselland and Schaffhausen, by HCB Holderbank Cement + Beton, NAGRA and Verein Schweizerischer Zement-, Kalk-und Gipsfabrikanten. 


\section{Summary - Résumé - Zusammenfassung}

This paper is based on 221 detailed stratigraphical sections that were measured between 1961 and 1995 in a strip between Biel and Boncourt in the west and Möhringen in southern Germany in the cast. The bulk of the studied sediments is of Oxfordian age, but many sections continue into the Kimmeridgian. More than 8000 ammonites and a great number of associated macrofossils were collected from in siu, almost all of them from measured sections. 2338 thin sections and a large number of polished slabs were prepared in order to describe 29 representative stratigraphical sections in the area between Biel, Boncourt and Balsthal. More than 5000 ammonites have been prepared in order to establish a detailed biostratigraphy. 68 stratigraphically significant ammonite taxa are described and figured. Subdiscosphinctes wojciechi and Ringsteadia suebica are new species, and Wegelea is a new genus. All the ammonite zones and subzones could be documented with ammonites. The majority of the zones and subzones are represented by the index ammonite. The high resolution stratigraphical correlation was constructed using lithostratigraphical marker beds, ammonite biostratigraphy, clay mineral stratigraphy and sequence stratigraphy. Several lithostratigraphical units, the Herznach Formation, Sornetan Member, Grellingen Member, Delémont Member, Buix Member and the Guinsberg unit in the rank of a formation are new.

The siliciclastic sediments were supplied from the northwest. An aceumulation of argillaceous deposits (Bärschwil Formation) was first laid down in the proximal part of the basin in the central Jura. In the middle Oxfordian a carbonate platform (St-Ursanne Formation) evolved on top of this argillaceous sediment pile. After this the siliciclastic sediment influx from the northwest resumed, the carbonate platform shrank greatly (Günsberg Formation), and the thick Effingen Member was laid down further out in the basin (Wildegg Formation). Another widespread carbonate platform was restored in the late Oxfordian and early Kimmeridgian (Balsthal Formation) and further evolved in the Kimmeridgian (Reuchenette Formation). A summary of the Oxfordian history of sedimentation is given in fig. 39. Fig. 40 is a correlation table.

Etude stratigraphique pluridisciplinaire de l'Oxfordien et du Kimméridgien (Jurassique supérieur) de la Suisse septentrionale et de la zone contiguë en Allemagne méridionale

\section{Résumé}

Ce travail a été réalisé par suite de l'étude de 221 coupes stratigraphiques détaillées qui ont été levées entre 1961 et 1995 dans une zone située entre Bienne et Boncourt à l'ouest et Möhringen en Allemagne méridionale à l'est. La plupart des sédiments étudiés est d'âge Oxfordien, mais plusieurs coupes s'étendent jusqu'au Kimméridgien. Plus de 8000 ammonites et la macrofaune accompagnante ont été prélevées d'en place. Presque tous les fossiles proviennent des coupes détaillées. 2338 lames minces et un grand nombre de surfaces polies ont été utilisées pour décrire 29 coupes stratigraphiques représentatives dans la région entre Bienne, Boncourt et Balsthal. La biostratigraphie des ammonites est basće sur plus de 5000 spécimens préparés et 68 descriptions et figurations d'espèces d'ammonites importantes pour la biostratigraphie. Subdiscosphinctes wojciechi et Ringsteadia suebica sont des espèces nouvelles, et Wegelea est un nouveau genre. Toutes les zones et les sous-zones d'ammonites sont représentées par des ammonites. La plupart des zones et des sous-zones d'anmonites a pu etre documentée par le taxon index. Les corrélations stratigraphiques à haute résolution sont faites par des niveaux repères lithostratigraphiques, la biostratigraphie des ammonites, la minéralostratigraphic et la stratigraphie séquentielle. Les suivantes unités lithostratigraphiques sont nouvelles: Formation d'Herznach, Membres de Sornetan, Grellingen, Delémont et Buix, et I'unité de Günsberg, élevée au rang de formation.

Les sédiments siliciclastiques proviennent du nord-ouest. Un amas de sédiments argileux (Formation de Bărschwil) a été d'abord déposé dans la partie proximale du bassin au Jura central.A 1'Oxfordien moyen, une plateforme carbonatée (Formation de St-Ursanne) s'est formée au-dessus de la pile de sédiments argileux. Ensuitc, l'apport de sediments siliciclastiques du nord-ouest a recommencé et la plateforme carbonatée s'est beaucoup contractée (Formation de Günsberg), Lépais Membre d'Effingen s'est sédimenté plus distalement dans le bassin (Formation de Wildegg). Unc nouvelle et large plateforme carbonatée (Formation de Balsthal) s'est établie au cours de rOxfordien terminal et du Kimméridgien précoce qui a continué d'évoluer pendant le Kimméridgien (Formation de Reuchenette). Une vue d'ensemble de l'histoire de la sédimentation durant lOxfordien est représentée sur la fig. 39. La fig. 40 cst un tableau de corrélation.

\section{Integrierte Stratigraphie des Oxfordian und} Kimmeridgian (Später Jura) in der Nordschweiz und im angrenzenden Süddeutschland

\section{Zusammenfassung}

Die vorliegende Arbeit stủtzt sich auf 221 stratigraphische Detailprofile, welche zwischen 1961 und 1995 auf einem Streifen zwischen Biel und Boncourt im Westen und Möhringen in Süddeutschland im Osten aufgenommen worden sind. Der grösste Teil der untersuchten Sedimente hat Oxford-Alter, aber manche Profile erstrecken sich weit bis ins Kimmeridgian. Mehr 
als 8000 Ammoniten samt der begleitenden Makrofauna sind aus dem Anstehenden entnommen worden. Fast alle diese Fossilien stammen aus den Detailprofilen. 2338 Dünschliffe und eine grosse Anzahl von polierten Anschliffen dienten dazu, 29 repräsentative stratigraphische Profile zwischen Biel, Boncourt und Balsthal zu beschreiben. Die detaillierte Ammoniten-Biostratigraphie beruht auf mehr als 5000 präparierten Ammoniten. 68 stratigraphisch wichtige Ammoniten-Taxa sind hier beschrieben und abgebildet. Neue Arten sind Subdiscosphinctes wojciechi und Ringsteadia suebica, während Wegelea eine netie Gattung ist. Alle Ammonitenzonen und -Subzonen sind durch Ammoniten vertreten. Der grössere Teil der Zonen und Subzonen ist durch das Index-Taxon belegt. Die hochauflosende stratigraphische Korrelation wurde mithilfe von lithostratigraphischen Leithorizonten, der Ammoniten-Biostratigraphie, der Mineralstratigraphie und der Sequenzstratigraphie durchgeführt. Mehrere neue lithostratigraphische Einheiten sind vorgeschlagen worden: Die Herznach-Formation, die Sorne- tan-, Grellingen-, Delémont- und die Buix-Schichten (Members) sowie die Günsberg-Einheit im Rang ciner Formation.

Die siliziklastischen Sedimente stammen aus dem Nordwesten. Eine tonige Schlammbank (Bärschwil-Formation) wurde zuerst im proximalen Bereich des Beckens im zentralen Jura abgelagert. Im mittleren Oxfordian entwickelte sich dann eine ausgedehnte Karbonatplattform (St-Ursanne-Formation) im seichten Wasser uber der Schlammbank. Danach setzte erneut siliziklastische Sedimentation aus Nordwesten ein. wodurch die Karbonatplattform auf den schmalen Streifen der Günsberg-Formation zusammenschrumpfte. Gleichzeitig wurden weiter draussen im Becken die mächtigen Effinger Schichten der Wildegg-Formation abgelagert. Eine neue, ausgedehnte Karbonatplattform bildete sich im späten Oxfordian (Balsthal-Formation) und entwickelte sich weiter im Kimmeridgian (Reuchenette-Formation). Eine Gesamtschau der Sedimentationsgeschichte im Oxfordian ist in Fig. 39 darge stellt. Fig. 40 ist eine Korrelationstabelle. 
ALtFNBACH, R. (1994): Geology of the Balmberg and surrounding area. Unpublished diplome paper, Univ. Bern, 142 p.

American Combussion on Strattgrapuic Nomenclatune (1961): Code of stratigraphic nomenclature. Bull. amer. Assoc. Petroleum Geol. $45 / 5,645-665$.

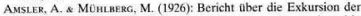
Schweizerischen Geologisehen Gesellsehaft nach Herznach und in den Jura zwischen Oensingen und Meltingen. Eclogae geol. Helv $19 / 3,684-692$.

AvdeLkovic, M.Z. (1966): Amoniti iz slojeva sa Aspidoceras acanthicum Stare Planine (istocna Srbija). Palaeontologica jugoslavica 6 5-136.

ARke1., W.J. (1925-27): The Corallian rocks of Oxford. Berks and North Wilts Phil. Trans, roy. Soc. London 216,67-181.

AkKEL.L. W.J. (1935-48): A monograph on the ammonites of the English Corallian Beds. Palaeontographical Society, London, 420 p.

Arkel.. W. J. (1941): The Upper Oxford Clay at Purton, Wilts, and the zones of the Lower Oxfordian. Geol. Mag. 78/3.161-172.

ARKELL, W.J. (1947): The geology of Oxford. Clarendon, Oxford. $267 \mathrm{p}$

ARKFL, W. I. (1956): Jurassic geology of the world. Oliver \& Boyd. Edinburgh and London, $806 \mathrm{p}$.

Arkelt, W. J., Kummel. B. \& Wricht, C.W. (1957): Mesozoic Ammonoidea. In: Moore, R.C. (ed.): Treatise on invertebrate paleontology, part L. Mollusca 4, p. 80-465. Geol. Soc. America s Univ. Kansas Press, Lawrence.

Arrops. F. (1982): La sous-famille des Ataxioceratinae (Ammonitina) dans le Kimméridgien inférieur du sud-esı de la France. Systématique, Evolution, chronostratigraphic des genres Orthosphinctes et Alaxioceras. Doc. Lab. Géol. Lyon, 83, 1-463.

Atrops, F., Gril, R. Matria, B. A. \& Wierzibowski, A. (1993): The Amoeboceras faunas in the Middle Oxfordian - lowermost Kimmeridgian. Submediterranean succession, and their correlation value. Acta geol pol. 43/3-4, 213-227.

Batмıн. W. W. (1989): Zur Geologie und Tektonik der WeissensteinKette zwischen Lommiswil und Gänsbrunnen. Unpublished diplome paper, Univ. Bern, $172 \mathrm{p}$.

BakвuLEsCu, A (1974):Stratigrafia jurasicului din vestul Dobrogei centralc. Editura Academiei Rep. soc. Romania, Bucuresti, 173 p.

BАRTHEL, K. W, \& SCHATRER, G. (1980): Zur Verbreitung von ldoceras balderum (OPFEL) (Ammonoidea, oberstes Unterkimmeridge) im südlichen Fränkischen Jura. Mitt. bayer. Staatsslg. Palaiont, hist. Geol. 20, 11-15.

Bates, R.L. \& Jackson, J.A. (1980); Glossary of geology. American Geological Institute, Falls Church, Virginia, 749 p.

BEsubouts, J. (1851): Mémoire sur le terrain Kelloway-oxfordien du Chattillonais Bull. Soc géol. France [2] 8, 582-600,

Besnosov, N. V. \& Mirra. V. V. (1995): Upper Jurassie ammonitids and the black shales in Central Asia. Scientific edition, Moskva (in russian), $121 \mathrm{p}$.

Bugot, A \& Brasil. L. (19014): Déscription de la faune des sables jurassiques supéricurs du Calvados. Mém. Soc. linn. Normandie 21, 1-24. $85-108$.

BitTerLi, P. \& Fischer. H. (1988): Erläuterungen zum Geologischen Atlas der Schweiz 1:25000, Blatt 1067 Arlesheim. Landeshydrologie und-geologie, Bern, $66 \mathrm{p}$.

Bı.UMrk, M. (1951): Fossile Kohlenwasserstoffe und Farbstoffe in Kalksteinen (Geochemische Untersuchungen III). Mikrochemie/microchim. Acta 37, 1048-1055.

Boben, K. (1911): Die Fauna des unteren Oxford von Popilany in Litauen. Gicol. palaeont. Abh. [N. F.] 10, 123-200.

BöHL.кE, J. E. \& ChAPLIN, C. G. C. (1970): Fishes of the Bahamas and adjacent tropical waters. 2 nd ed. Livingston, Wynnewood, Pa, $771 \mathrm{p}$.

Bot.t.IGer. W. \& BUR, P. (1967): Versuch einer Zeitkorrelation zwischen Plattormcarbonaten und ticfermarinen Sedimenten mit Hilfe von Quarz-Feldspat-Schüttungen (mittlerer Malm des Schweizer Jura) Eclogae geol. Helv, 60/2, 491-507.
BoLliger, W. \& Bukk, P. (1970): Sedimentologic von Schelf-Carbonaten und Beckenablagerungen im Oxfordien des zentralen Schweizer Jura. Beitr. geol. Karte Schweis [N. F.] 140, 96 p.

Bouluer, A. (1993): Intérêt des brachiopodes jurassiques en paléobathymétrie. Bull. ann. Assoc. géol. auboise 15, 15-25.

BourseaU, J.P. (1977): LOxfordien moyen à nodules des Terres noires" de Beauvoisin (Drôme). Nouv. Arch Mus Hist.nat. Lyon 15. $1-116$.

BrochWICZ-LEWINSKI, W. (1972): Middle Oxfordian representatives of the genera Lithacoceras Hystr, 1900, and Liosphinctes Buckman, 1925, from the Polish Jura Chain. Acta geol. pol. 22/3, 473-497.

Brochwicz-Lewinski, W. (1973): Some remarks on the origin of the subfamily Idoceratinae SPATH, 1924 (Perisphinctidae, Ammonojdea). Acta palaeont pol. 18/3, 299-320.

Brochwic-Lewinski. W. (1975a): On the Oxfordian genus Subdiscosphinctes MaL.INowsKA, 1972, and subgenus Aurelmontanites nov. (Perisphinctidae, Ammonoidea). Acta palaeont pol. 20/1.87-96.

Brocuwicz-I.rwinski. W. (1975b): Oxfordian of the Crestochowa area. I. Biostratigraphy. Bull. Acad. pol. Sci. [Sci. Terre] 24/, 37-46.

Brochwicz-LewINSKI. W. (1980): Perisphinetids proper (Ammonoidea) of the Czestochowa Oxfordian. II Subgenera Dichotornosphincies BuckMAs, 1926 and Dichtomoceras BuckMas, 1919. Bull. Acad.pol. Sci. [Sci. Terre] 27/3-4, 205-218.

Brochwicz-LewTNskt, W. \& Rozak, Z (1976a): Some difficulties in recognition of sexual dimorphism in Jurassic perisphinetids (Ammonoidea). Acta palacont. pol. $21 / 1,115-125$.

BRocHWICZ-LEWINSK, W. \& RozAK, Z. (1976b): Oxfordian idoceratids (Ammonoidea) and their relation to Perisphinctes proper. Acta palaeont, pol. 21/4,373-390.

BǗCH. U.P. LEMCKE, K., WItner, G, \& ZIMDARs, J. (1965): Geologische Ergebnisse der Erdölexploration auf das Mesozoikum im Ünter. grund des schweizerischen Molassebeckens. Bull. Ver. Schweiz. Petrol.-Geol. u. -Ing, 32/82, 7-38.

BuCKMAN, S.S. (1909-1930): [Yorkshire] Type Ammonites, vol. 1-7, reprint (1972) of Wheldon \& Wesley, Codicote, $790 \mathrm{pl}$.

Busor. L. G. (1993): Stratigraphical implications of the relationship between ammonites and facies; examples from the Lower Cretaceous (Valanginian-Hauterivian) of the western Tethys. Ir: House, M. R. ed.: The Ammonoidea: environment, ecology, and evolutionary change. Systematics Assoc. spec. Vol. 47. p.243-265. Clarendon Press, Oxford.

BukKHALTER, R.M. (1989): Zur Geologic der Grenchenberg-Kette zwischen Obergrenchenberg und Hasenmatt (Kantone Solothum und Bern). Unpublished licentiate thesis, Univ. Bern, 241 p.

BurKHлro, A. (1978): Baryt-Coclestin und ihre Mischkristalle aus Schweirer Alpen und Jura. Schweiz mineral petrogr. Mitt. 58,1-96.

Buxrorr, A. (1907): Geologische Beschreibung des Weissenstein-Tunnels und seincr Umgebung. Beitr. gcol. Karte Schweiz [N.F.] 21, $1-125$.

CAllonos, J. H. (1960): New sections in the Corallian Beds around Oxford, and the subzones of the Plicatilis Zonc. Proc: Geologists' Assoc. $71 / 2,177-208$

CALlomon, J.H. (1964): Notes on the Callovian and Oxfordian Stages. Colloque du Jurassique Luxembourg 1962. Publ. Inst. grand-ducal, Sect. Sci nat, phys math. p. $269-291$. St. Paul, Luxembourg.

CAllomon, J.H. (1973): On Campylites Roluer, 1922 and Neoprionoceras SPATH, 1928 (Ammonoidea, Jurassic). I. Paleontology 47/5. 1003.

Cakiou, E. (1966): Les faunes d'ammonites et la sédimentation rythmique dans IOxfordien supérieur du seuil du Poitou. Trav. Inst Géol. Anthrop préhist. Fac. Sci. Poitiers 7, 45-67.

Capiou, E. Mfiendez, G. (1990): A modified perisphinetid zonation for the Middle Oxfordian of southern Europe, submediterranean province. In: Melendez. G. (ed.): 1st Oxfordian Working Group meeting (Int. Subcommission on Jurassic Stratigraphy) Zaragoza 1988 (p. 129-151). Publ.Seminario Paleont. Zaragoza (SEPAZ) vol.2 
Cariol, E. Arrops, F., Hantzyeggue,P. Enay, R. \& Rrovlt, M. (1991a) Oxfordien. Réactualisation des échelles d'ammonites. In: 3rd International Symposium on Jurassic Stratigraphy (p. 132). Poitiers, France. Vol. of ahstracts, $134 \mathrm{p}$.

Cariou, E., Mrlandez, G., \& Bravger. P. (1991b): Détinition d'une échelle biochronologique fine pour une zone d'ammonites de rox. fordien moyen: zone à Transversarium (province subméditer ranéenne). C. R. Acad. Sci. (Paris) 313 [Sér. II] , 703-708.

Chauve, P., Martin, J. \& Batlix, C. (1985): Note explicative de la feuille Delle a $1: 50000$. Carte géologique de la France. Bur. Rech. géol. min., Orléans, $31 \mathrm{p}$.

ChecA. A. (1985): Los Aspidoceratiformes en Europa (Ammonitina, fam. Aspidoceratidac: subfamilias Aspidoceratinae y Physodoceratinae). Ph. D. thesis Univ Granada, 413 p.

Choffat. P (1878): Etudes géologiques sur la chaine du Jura. 1. Esquisse du Callovien et de l'Oxfordien dans le Jura occidental et le Jura méridional. Mém. Soc. Emul. Doubs [5] 3, 80-198.

Chnss, H.A. (1961): Ober Campylites und Trimarginites (Ammoncidea, Jura). N.Jb. Geol. Palăont. Abh. 111/3,274-325.

Clari, P. A. Martirf, L s Pavia, G. (1990): L'unità selcifera del Rosso Ammonitico Veronese (Alpi Meridionali). Atti 11 Conv. int. F. E.A. Pergola, 87, 151-162

CLovo, P.E. (1962): Environment of calcium carbonate deposition west of Andros islund, Bahamas Geol. Surv, prof. Pap. 350, 1-138.

COE. A.L. (1992): Uneonformities within the Upper Jurassic of the Wessex Basin, Southern England. Unpublished Ph. D. thesis, Univ. Oxford, $235 p$.

COE, A. L. (1995): A comparison of the Oxfordian successions of Dorset, Oxfordshire and Yorkshire. In: Tavion, P. D. (ed.): Field geology of the British Jurassic. Spec. Rep,geol.Soc, London, 151-172.

CoE, A.L. \& Gygl. R.A. (1994): A comparison of the Oxfordian and Kimmeridgian between northern Switzerland and the United Kingdom using sequence stratigraphy. Abstract amer. Assoc. Petroleum Geol meeting. Denver 1994, 3, 123.

Collignon. M. (1959):Atlas des fossiles caractéristiques de Madagascar, part 4 (pl. 34 - 95. Argovien-Rauracien). Serv, géol. Tananarive.

Colloour Du Jurassioue Luxembourg 1962 (1964): Recommendations Publ. Inst. grand-ducal, Sect. Sei. nat. phys. math., p. 84-86. St-Paul, Luxembourg

Conmst, D.(1976): Evolution des milieux de sedimentation au cours de l'Oxfordien en Franche-Comté, Bull. Féd. Soc. Hist. nat. FrancheComić $77,43-54$

Cross, T. A. \& Homewood, P. W. (1997): Amanz Gressly's role in founding modern stratigraphy. Bull. geoL. Soc. Amer. 109/12, 1617-1630.

Cumings. E. R. (1932): Recfs or bioherms? Bull. geol. Scc. America 43 , $331-352$

Cumings, E.R. \& Sняock, R. R. (1928): Niagaran coral reefs of Indiana and adjacent states and their stratigraphic relations. Bull. geol. Soc. America 39.579-620

Degrand-Passard, S. (1982): Le Jurassique supérieur du Berry (sud du bassin de Paris - France). Mém. Bur. Rech. géol. min. 119, 1- 227.

Delhafs. W. . Gerth. H (1912): Geologische Beschreibung des Kettenjura zwischen Reigoldswil (Baselland) und Oensingen (Solothurn), Geol, palaeont. Abh. [N. E] 11, 1-97.

Desor, E \& Gressty. A. (1859): Etudes géologiques sur le Jura neuchitelois. Mem. Soc. Sci. nat. Neuchâtel 4, 1-159.

Dicksov, J.A. D. (1966) Carbonate identification and genesis as revealed by staining. J. sed. Petrol. $36 / 2,491-505$.

Donovas, D. T. Chllomov, J.H. \& Howarth. M.K. (1981): Classification of the Jurassic Ammonitina. In: House, M.R. \& Senior. J. R. (eds.): The Ammonoidea. Systematics Assoc. spec. vol. 18 . p. 101-155. Academic Press, London.

Dors, P. (1930): Die Ammonitenfauna des untersten Malm der Frankenalb. L. Die Perisphincten. Palaeontographica 73, 107-172.

Dorv. P (1931): Die Ammonitenfauna des untersten Malm der Frankenalb. H. Die Aspidoceraten. Palaeontographica 74,1-92.

DUNнAм, R. I (1962): Classification of carbonate rocks according to depositional texture. Ir: HAM, W. E. (ed.): Classification of carbonate rocks. Amer. Assoc. Petrol. Geol. Mem. 1, 108-121.

DuNнам, R. J. (1969): Early vadose silt in Townsend mound (recf). New Mexico. In:Friedsax, G. M. (ed.):Depositional environments in earbonate rocks. Spec. Publ. Soc. econ. Paleont. Mineral. 14, 139-181.

Duong, D-M. (1974): L'Oxfordien moven et supéricur à facics grumeleux de la Cluse de Chabrières (Basses-Alpes):milieu de sédi- mentation, biostratigraphic, paléontologie. Unpublished $\mathrm{Ph}$. D. thesis ( 3 rd cycle), Univ. Claude Bernard, Lyon, $140 \mathrm{p}$.

EgGER, M. (1991): Der obere Dogger und der untere Malm im Steinbruch Chalch-Sehïmel zu Holderbank (AG). Fauna, Biostratigraphie, Palókologie. Unpubl, licentiate paper, Univ. Bern, 117 p

Eмro, A. F. \& KLovav, J.E. (1971): A Late Devonian reef tract on northeastern Banks Island, N. W. T.. Bull. canad. Petroleum Geol $19 / 4,730-781$

ENar, R. (1963): Contribution à l'ćtude palćontologique de l'Oxfordien superieur de Trept (Isere). I. Stratigraphie et ammonites. Trav. Lab. Géol. Lyon [N.S.] 8, 7-81.

ENaY. R. (1964): Les faunes d'ammonites et la zonation de l'Oxfordien supérieur du Jura méridional. Colloque du Jurassiçue, Luxembourg 1962, Publ. Inst. grand-ducal, Scet. Sci. nat, phys, math., p. 487-501. St. Paul. Luxembourg.

Enay, R. (1966): L'Oxfordien dans la moitié Sud du Jura français. N Arch. Mus. Hist. nat. Lyon 8/1-2,1-624.

Enay. R. \& Boullier,A. (1981): Làge du complexe récifal des Côtes de Meuse entre Verdun et Commercy et la stratigraphic de l'Oxfordien dans l'Est du Bassin de Paris. Geobios 14,6, 727-771.

ENAy, R., ContINI, D. \& Boullier. A. (1988): Le Séquanien-type de Franche-Comté (Oxfordien supérieur): datations et corrélations nouvelles, conséquences sur la paléogéographie et révolution du Jura et régions voisines. Eclogae geol. Helv. 81, 295-363.

Eralion, M. A. (1862): Etudes paléontologiques sur le Haut-Jura. Monographie du Corallien. Mém. Soc. Emul. Doubs [3], vol.6. $53-260$

FAVRE. E. (1875): Description des fossiles du terrain Jurassique de la Montagne des Voirons (Savoie). Mêm. Soc, paléont. suisse 2, 1-77.

Favre, E. (1876) Descriotion des fossiles du terrain Oxfordien des Alpes fribourgeoises. Mem. Soc. paléont. suisse 3,1-75.

Finkel, R. (1992): Eine Ammoniten-Fauna aus dem Kimmeridgium des nordístlichen Keltiberikums (Spanien). Profil 3, 227-297.

Fischer. H. (1965a): Geologie des Gebietes zwischen Blauen und Pirter Jura (SW Basel). Beitr. geol. Karte Schweiz [N F.] 122, 1-106.

Fischer. H. (1965b): Oberer Dogger und unterer Malm des Berner Jura: Tongruben yon Liesberg. Bull. Ver. Schweiz. Petrol.-Geol. u. -Ing. 31/81, 25-36.

Fischer, H. \& Groi, R. (1989): Numerical and biochronological time scales correlated at the ammonite subzone level: $\mathrm{K}-\mathrm{Ar}$, Rb-Sr ages, and $\mathrm{Sr}, \mathrm{Nd}$ and $\mathrm{Pb}$ sea-water isotopes in an Oxfordian (Late Jurassic) succession of northern Swizerland. Bull. geol. Soc. America 101 $1584-1597$.

Ficouet, M.. Javaux, C., Menot, J. C. a Purser, B. H. (1991): Sedimentation, diagenese et séquences de dépót dans les séries carbonatées de la plate-forme d’ăge Bathonien à Oxfordien en Bourgogne. Livret-guide de l'excursion de l'Assoc. Séd. français 27-29 juin $1991,174 \mathrm{p}$.

FLUGEL. E. \& Frank, H. E. (1967): Uber die lithogenetische Bedeutung von Coeeolithen in Malmkalken des Flachwasserbereiches. Eclogac geol. Hetv. 60'1.1 1-17

FoLk, R. L. (1962): Spectral subdivision of limestone types. $m$ : HaM. W. E. (ed.): Classification of carbonate rocks. Amer. Assoc. Petrol. Geol. Mem. 1,62-84.

Fontana. B. (1990): El Oxfordiense Medio, Biozona Transversarium (Jurasico Superior) en el borde Sur de la Cuenea del Ebro (Cordillera Iberica). Estudio paleontologico del genero Larcheria (Ammonoidea, Perisphinctidae). Tes. Licenciatura Univ. Zaragoza. $123 \mathrm{p}$

Fortwengler, D. \& MArchand, D. (1994): The Thuoux section: Callovian-Oxfordian boundary (Lamberti to Mariac Zone) under "Terres Noires" facies. In: Athops, F. \& MELEndez, G. (eds.): 4th Oxfordian \& Kimmeridgian Working Groups Meeting, Lyon and southeastern France basin, Guide Book \& Abstracts, 103-106, Lyon.

GAsche, E. (1956): Ober die Entstehung der Mumien und ubrigen Kalkknollen aus dem Sequan des Berner Jura. In: Ziegler. P. A. Zur Stratigraphie des Séquanien in zentralen Schweizer Jura, p. 43-46. Beitr. geol. Karte Schweiz [N. F.] 102

Geologischer Atlas der Schweiz 1:25000 (1936): Blatt no. 3, LaufenBretzwil-Erschwil-Mümliswil. Geol. Komm. Schweiz, Basel.

Geologischer AtLas der Schweiz 1:25000 (1963): Blatt $1085 \mathrm{St}-\mathrm{Ut}$ sanne $($ no, 40). Geol. Komm. Schwciz, Bascl

Geologischer AtLas der Scirvetz 1:25000 (1984): Blatt 1067 Arlesheim (no. 80). Geol. Komm. Schweiz. Basel. 
Gevrey, A. (1900): Oecoprychius diristoli Beaudouin sp. Trav. Lab. Géol. Fac. Sci. Univ. Grenoble 5,45.

Geyer. O.F. (1961): Monographic der Perisphinetidae des unteren Unterkimeridgium (Weisser Jura $\gamma$, Badenerschichten) im suddeutschen Jurat. Palaeon lographica $[A]$ 117, 1-157.

Ginseuro, R. N., Hardie. L. A.. Bricker, O.P. Garretr, P. \& WaNless, H.R. (1977): Exposure index: A quantitative approach to defining position within the tidal zone. In: Sedimentation on the Modern carbonate tidal flats of northwest Andros Island, Bahamas (ed. by Harsn, L. A.). Johns Hopkins Univ, Stud. Geol. 22, 7-11.

Gizenewska.M. \& Wieczorek, J. (1977): Remarks on the Callovian and Lower Oxfordien of the Zalas area (Cracow Upland. Southern Poland). Bull Acad pol. Sci. [Sci. Terre] 24, 167-175.

Glowniak, E. (1997): Middle Oxfordian ammonites. In: Glowniak, E., Matyus, B. A. Poulsen. N. E. \& Wierzeowski, A.: Oxfordian (Jurassic) meeting in Poland, 26-28 May 1997. Internat. Subcomm. Jurassic Stratigr. Newsletter 25, 45-46.

GradsterN, F. M., Agterderg. F.P., OGo.J. G., Har.dendol, J., van Veen. P., Thierry, J. \& Hunng, Z (1995): A Triassic, Jurassic and Cretaceous Time scale. Spec. Publ. Soc. eoon. Paleont. Mineral. 54, 95-126.

Grepris, E. (1893): Etudes sur les mollusques des couches coralligenes des environs d'Oberbuchsiten. Mém. Soc. paléont. suisse 20, 1-109.

Gkeprix, J.B. (1867): Essai géologique sur le Jura suisse Helg \& Boéchat. Delémont, $152 \mathrm{p}$.

GeEppIN, J.B. (1870): Description géologique du Jura bernois et quelques districts adjacents. Matér. Carte géol. Suisse 8, 1-357.

GrissLy.A. (1838-41): Observations géologiques sur le Jura soleurois. Nouv. Mém. Soc. helv. Sci. nat. $2,4,5,349$ p.

Gressty. A. (1864): Rapport géologique sur les terrains parcourus par les lignes du réseau des ehemins de fer jurassiens par le Jura bernois. In: Rapports concernant le reseau des chemins de fer du Jura bernois Annexe 3.p. 87-105. Rieder \& Simmen. Bern.

Gyoi, R. A. (1966): Ober das zeitliche Verhalltnis zwischen der transversarium-Zone in der Schweiz und der plicatilis-Zone in England. (Unt. Malm. Jura). Eclogae geol. Helv. 59/2, 935-942.

Gyal, R.A. (1969): Zur Stratigraphic der Oxford-Stufe (oberes JuraSystem) der Nordschweiz und des suddeutschen Grenzgebietes. Beitr. geol. Karte Schweiz [N. F.] 136,1-123.

GyGr, R. A. (1973): Tektonik des Tafel- und Faltenjura vom Rhein bei Koblenz bis nach Wildegg. Schichtfolge von der Trias bis ins Tertiar. Jber. Mitt, oberrh. geol. Ver. [N. F] 55, 13-22.

Gygi, R. A. (1975): Sparisoma viride (Bonnsterne), the Stoplight Parrotfish, a major sediment producer on coral reefs of Bermuda? Eclogae geol. Hely. 6822,327-359.

GyGi, R. A. (1977): Revision der Ammonitengattung Gregoryceras (Aspidoceratidae) aus dem Oxfordian (Oberer Jura) der Nordschweiz und von Suddeutschland. Taxonomic. Phylogenie, Stratigraphic. Eclogae geol. Helv. 70/2, 435-542.

Gygr. R. A (1981): Oolitic iron formations: marine or not marine? Eclogae geol Helv. 74/1,233-254.

Gyc1. R.A. (1982): Sedimentation und Facies des Spaten Jura im zentralen Juragebirge. Jber. Mitt. oberth geol. Ver, [N. E.] 64. 17-28.

Gror, R.A. (1986): Eustatic sea level changes of the Oxfordian (Late Jurassic) and their effect documented in sediments and fossil assemblages of an epicontinental sea. Eclogae geol. Helv. 79/2. $455-491$.

GyGI, R. A. (1990a); The Oxfordian ammonite succession near Liesberg $\mathrm{BE}$ and Péry BE, northern Switzerland. Eclogae geol. Helv. 83/1. $177-199$.

Groi, R.A. (1990b): The Oxfordian in notthern Switzerland. Guidebook for the field excursion to the Swiss Jura of the Oxfordian Working Group, p. 17-70, Internat. Subcomm. Jurassic Stratigr., Basel.

Gro1. R. A. (1990c): Dic Paläogeographie im Oxfordium und frühesten Kimmeridgium in der Nordschweiz. Jh. geol. Landesamt Bad.-Würtemb. 32, 207-222.

Gyor. R. A (1991a): Proposed validation of the specific names crenatus BRUGUIERE, 1789, and renggeri OpPEL, 1863 (Class Cephalopoda, Order Ammonoidea) from the Oxfordian Stage of the Upper Jurassic. Palãont. Z. 65, 119-125.

GvG, R. A. (1991b): Die vertikale Verbreitung der Ammonitengattungen Glochiceras, Creniceras und Bukowskites im Spaten Jura der Nordschweiz und im angrenzenden Süddeutschland. Stuttgarter Beitr. Natkd. [B] 179.1-41.
GYGr, R.A. (1992): Structure, pattern of distribution and paleobathymetry of Late Jurassic microbialites (stromatolites and oncoids) in northern Switzerland. Eclogae geol. Helv. 85/3.799-824.

GYGI, R.A. (1995): Datienung von Seichtwassersedimenten des Spaten Jura in der Nordwestschweiz mit Ammoniten. Eclogae geol. Helv. $\mathrm{BS} / 1,1-58$.

GYG, R.A., COE,A.L. \& VAIL,P. R. (1998): Sequence stratigraphy of the Oxfordian and Kimmeridgian (Late Jurassic) in northem Switzerland. In: Mesozoic-Cenozoic sequence stratigraphy of European basins (ed. by Haroendol, J, DE Gracianskv, P.C. Thimrky, J., Farlex, M. \& Vall. P.R.). SEPM (Soc. sed. Geol.) spec. Publ.60. $527-544$

Gygi, R.A. \& Hulebranot, A. von (1991): Ammonites (mainly Grego. ryceras) of the Oxfordian (Late Jurassic) in northern Chile and time-correlation with Europe. Schweiz paläont. Abh. 113, 135-185.

Gygr, R.A. \& Marchand, D. (1982): Les faunes de Cardioceratinate (Ammonoidea) du Callovien terminal et de l'Oxfordien inférieur et moyen (Jurassique) de la Suisse septentrionale: Stratigraphie, paléoćcologie, taxonomie prélininaire. Geobios 15/4,517-571.

Gygi,R.A.\& Marchand, D (1993): An early Oxfordian ammonite bed in the Terrain a Chailles Member of northern Switzerland and its sequence stratigraphical interpretation. Eclogae geol. Helv. 86/3, 997-1013.

Gygi, R.A. \& MeDowel. F. W. (1970): Potassium-argon ages of glauconites from a biochronologically dated Upper Jurassic sequence of northern Swizerland. Eclogae geol. Helv. 63/1,111-118.

Gygi, R.A. \& Persoz, F. (1986): Mineralostratigraphy, litho- and biostratigraphy combined in correlation of the Oxfordian (Late Jurassic) formations of the Swiss Jura range. Eclogae geol. Helv. 79/2. $385-454$.

Gyct, R.A. \& Pensoz, F. (1987): The epicontinental sea of Swabia (southem Germany) in the Late Jurassic - factors controlling sedimentation. N.Jb. Geol. Palăont. Abh. 176/1, 49-65.

Gygt, R.A., SAdati, S.-M. \& Zerss, A. (1979): Neue Funde von Paraspidoceras (Ammonoidea) aus dem Oberen Jura von Mitteleuropa Taxonomic. Okologic. Stratigraphic. Eclogac geol. Helv. 72/3, $897-952$

HaAs, O. (1955): Revision of the Jurassic ammonite fauna of Mt. Hermon, Syria. Bull, amer. Mus, nat. Hist. 108/1,3-210.

Hallum. A. (1978): Eustatic cycles in the Jurassic. Palaeogeogr. Palaeoclimatol. Palaeoccol. 23, 1-32.

Ha, B. U., HARISENBoL, J., \& VAIL, P. R. (1987): Chronology of fluetuat ing sea levels since the Triassic. Science, 235, 1156-1167.

HastMax, W.D. (1958): Natural history of sponges of southern New England. Bull. Peabody Mus. nat. Hist. 12,1-155.

Huusfr, M. (1994): Geologie der Region Péry-Reuchenette (Kanton Bern). Unpublished diplome paper. Univ. Bern. 195 p.

HECKIENDORN, W. (1974): Zur Tektonik der Vellerat-Antiklinale. Beitr. geol. Karte Schweiz [N F.] 147. Bern. 1-49

HEDBERG, H. D., ed. (1976): International stratigraphic guide, Wiley, New York. 200 p.

Herm A. (1919): Geologie der Schweiz. Vol. 1: Molasseland und Juragebirge, Tauchnitz, Leipzig, $704 \mathrm{p}$.

Hel.ter, F. \& Zaiss, A. (1972): J. M. C. Reinecke und sein Werk: Des Urmeeres Nautili und Argonautae aus dem Gebiet von Coburg und Umgebung, Erlanger geol. Abh. 90, 1-42.

Hess, H. (1975): Die fossilen Echinodemen des Sehweizer Juras Veröff, nat. hist. Mus. Basel $8,1-130$.

Holder. H. (1955): Die Ammoniten-Gattung Tarumelliceras im südwestdeutschen Unter* und Mittelmalm. Palacontographica [A], 106 $37-153$.

HoROLDT, U.(1964): Morphologie und Systematik der weissjurassischen Ammonitengattungen Streblites und Ochetoceras unter hesonderer Berücksichtigung des Hohlkiels. Ph. D. thesis Univ. Tübingen. $105 \mathrm{p}$

Hummel, K.L. (1914): Die Tektonik des Elsgaues. Ber, natf. Ges. Freiburg i. Br. 20, 205-285.

Hunr, M. (1969). A preliminary investigation of the habits and habitat of the rock-boring urchin Echinometra lucunter near Devonshire Bay, Bermuda. In: Grvseurc, R. N. \& G Grret, P. (eds.): Seminar on organism-sediment intcrelationships Bermuda Biological Station for Research Spec. Publ. 2,35-40.

INsulaco, E. (1996): Upper Jurassic microsolenid biostromes of northern and central Europe: facies and depositional environment. Palaeogeogr. Palacoclimatol. Palacoecol. 121, 169-194. 
INTERTational Code of Zoological Nomenclature (1985): 3rd edition. Internat. Irust zool. Nomenclat. London, $338 \mathrm{p}$

JAMrs, N. P. a GinsBURG, R.N. (1979): The seaward margin of Belize barrier and atoll reefs. Internat. Assoc. Sedimentologists spec. Publ. 3. $1-191$.

JEANNET, A. (1951): Stratigraphie und Palaeontologie des oolithischen Eisenerzlagers von Herznach und seiner Umgebung. 1. Teil. Beitr. Geol. Schweiz, geotech. Ser. [13] 5, 1-240.

JUILLERAT, E. (1907): Relations entre le Malm du Jura central et celui du canton d'Argovie. Soc gén. Imprimerie, Genève, 72 p.

KeHrer, L. (1922): Beiträge zur Kenntnis der Geologic von Olten-Aarburg und Umgebung, Sauerlander, Aarau, $46 \mathrm{p}$.

Kendall, C. G. S. C.e Skipwirh. P. A. (1968): Recent algal mats of a Persian Gulf lagoon. J. sed. Petrol. 38, 1040-1058.

KINSMAN, D.J.J. (1969): Interpretation of $\mathrm{Sr}^{+2}$ concentrations in carbonate minerals and rocks J sed. Petrol. $39 / 2,486-508$.

Kosy, F. (1892): Etude stratigraphique des couches rauraciennes supérieures du Jura bernois. Mém. Soc, paléont suisse 19,374-413.

Kосн. R. (1923): Geologische Beschretbung des Beckens von Laufen im Berner Jura. Beitr. geol. Karte Schweiz [N. F.] 48/2. Bern. 1-60.

KravtTER, M. (1994): Gregoryceras aus dem Weissen Jura a (Oxfordium) vom "Lochen" bei Balingen (Schwabische Alb, Baden. Wuirttemberg), Jber. Mitt, oberrh. geol. Ver. [N. F] 76, 325-334.

K.LENEN, P.H. (1960): Experimental abrasion of sand grains. [nt. geol. Congr, Rept.21si Sess Norden, Part X, 50-53.

KuENEN, P.H. (1964): Marine geology. Sth printing. Wiley, New York. $568 \mathrm{p}$.

Kugler, C (1987): Die Wildege-Formation im Ostjura und die SchiltFormation im östlichen Helvetikum: ein Vergleich. Mitt. geol. Inst. ETH Univ. Zurich [N. F.] 259, 1-209]

LANG, F. (1863): Geologische Skizze der Umgebung von Solothurn. Scherer, Solothurn, $32 \mathrm{p}$.

LANGE, W. (1973): Ammoniten und Ostreen (Biostratigraphie, Okologie, Zoogeographie) des Callovium/Oxfordium-Grenzbereichs im Wiehenpebirge. Münster. Forsch. Geol. Palliont. 27.1-209.

LAUBscher.H. (1948): Geologie des Gebietes von Siegfriedblatt St-Ursanne (Berner Jura). Beitr. geol. Karte Sehweiz [N, F. 192, 1-49.

Lebert, A. Marchand. D. (1982): Le Callovien superieur et roxfordien inférieur de l'Orne et de la Sarthe (Franee). Nouvelles données stratigraphiques, paléontologiques et paléobiogéographiques. Bull. Bur. Rech. géol min. [2] I, 4, 239-254.

LeXiQue Stratigraphique International. (1961): Fase. 7a, Jura et Fossé du Rhin. Centre nat. Rech, sci. Paris, $314 \mathrm{p}$.

Lineer. H. (1925): Geologie des Delsberger Beckens und der Umge. bung won Movelier. Beitr. geol. Karte Sehweiz [N. F.] 55/4, 1-71.

Liviciz, H. (1970): Erlauterungen zum Geologischen Allas der Schweiz 1:25000, Blatt 1065 Bonfol. Kümmerly \& Frey. Bern, 39 p.

LoktoL, P. DE (1878): Monographie paléontologique des couches de la Zone a Ammonites temuilobatus (Badener Schichten) de Baden (Argovie). Troisième et dernière partie. Mém. Soc. paléont. suisse 5. $77-200$

LorioL, P. DE (1896): Etude sur les mollusques et brachiopodes de $1 \mathrm{Ox}$ fordien supéricur et moyen du Jura bernois. Première partic. Mém. Soc. paleont, suisse $23,1-77$.

Loriol P. DE (1901): Etude sur les mollusques et brachiopodes de rOxfordien superieur et moyen du Jura bernois. Premicr supplément. Mèm. Soc. paléont. suisse 28, 1-119.

LoweNSTAM, H. A. (1950): Niagaran reefs of the Great Lakes atea. J Geology $58,430-487$.

LoweNSTAM, H.A. (1955): Aragonite needles secreted by algae and some sedimentary implications. J sed. Petrol. 25/4, 270-272.

LowenstaM, H. A. \& Epstan, G. (1957): On the origin of sedimentary aragonite needles of the Great Bahama Bank. J. Geology 65/4. $364-375$

Macintyre, I. G., Graus, R. R. Reinthal. P.N. Littler, M. M. \& Lat ILER. D.S. (1987): The Barrier Reef sediment apron: Tobacco Reef Belize. Coral Reefs $6 / 1,1-12$

Macintyre, I. G. \& Reib, R.P. (1992): Comment on the origin of aragonite needle mud: a picture is worth a thousand words. J. sed. Petrol 62/6. 1095-1097.

Mnkowski, H. (1963): Problem of sexual dimorphism in ammonites Palaeontologia pol. 12,1-92,

Muıvowsk, L (1963): Suratygrafia Oksfordu Jury Crestochowskiej na podstawie Amonitow, Inst. geologiczny, Prace, 36, 1-165.
Malingwska, L. (1967): Biostratigraphy of Lower and Middle Oxfordian deposits in the margin of the Swietokrzyskie Mountains Instytut geologiczny. Biuletyn 209,53-112.

Mal. Inowska. L. (1972a): The Middle Oxfordian Perisphinctidae of Zawodzic near Crestochowa (Poland). Acta palacont pol.17/2. $167-242$.

MALINowska, L. (1972b): Srodkowy i gorny Oksford w polnocno-zachodniej cresci Jury crestochowskicj. Instytut geologiczny. Biuletyn $233,5-67$.

MarchaND. D. (1970): Les Quenstedroceras de la Zone a Quenstedtoceras lamberti en France. Ph. D. thesis (3rd cycle). Unjv. Dijon. $136 \mathrm{p}$.

MArCHAND. D. (1986): L'évolution des Cardioceratinac d'Europe occidentale dans leur contexte paléobiogéographique (Callovien supérieur-Oxfordien moyen). Thèse de doctorat ès sciences. Univ. Dijon. 601 p.

MArchind, D. \& Fortwengler, D. (1994): Vertical range of the major species found in the "Terres Noires" Formation at the Callovian-Oxfordian boundary. In: Amors. F. \& MELENDLz. G. 4th Oxfordian a Kimmeridgian Working Groups Meeting, Lyon 1994, guide book \& abstracts (p. 79, fig. 21). Lyon.

Marchand, D., Menot, J-C. \& Perke, P. (1982): Sur la présence du genre Larcheria TINTANT dans la zone a Bifurcatus (sous-zone à Stenocycloides) de Bourgogne, Bull. sci. Bourg, 35/2, 101-113

Marcou. J. (1848): Recherches géologiques sur lc Jura salinois Première partie. Mém. Soc. géol. France [2] 3,1-151.

Maktis, B. (1984): Zur Geologie der Weissenstein-Kette zwischen Matzendorf (SO) und Wiedlisbach (BE). Unpublished ficentiate thesis Univ. Bern, 283 p.

MATyA, B. A (1977):The Oxfordian in the south-western margin of the Holy Cross Mts Acta geol. pol. 27/1, 41-64.

Matyja. B.A. \& Wierzenowski, A. (1988): The two Amoeboctras inva sions in submediterranean Late Oxfordian of central Poland. $\mathrm{m}$ : Rocha, R. B. \& Soskıs, A. E. (eds.) : 2nd International Symposium on Jurassic Stratigraphy, 1987, symposium vol. 1.421-432. Lisboa.

MATYA, B. A. \& Wrerznowsk1, A. (1994): On correlation of submediterranean and boreal ammonite zonations of the middle and upper $\mathrm{Ox}$ fordian: new data from central Poland. In: CARIOU, E. \& HANTZPER GUE, P. (eds, ): 3eme Symposium international de stratigraphie du Jurassique, Poitiers 1991. Gcobios, Mém. spéc. 17, 351-358.

Melendez, G. (1984): El Oxfordiense en el sector central de la Cordillera Iberica (Provincias de Zaragoza y Teruel). Ph.D. thesis Univ, complutense Madrid. $825 \mathrm{p}$.

Mrinndez, G. (1989): El Oxfordiense en el sector central de la Cordillera Iberica (Provincias de Zaragoza y Teruel). Inst. Femando el Catolico, Zaragoza, $418 \mathrm{p}$.

Melendez, G.. SLQuetros, L. \& Brochwic2-LewiNski, W. (1984): Paleobiogeographic position of Oxfordian ammonite fauna of the lberian Chain (Spain). Bull. pol. Acad. Sci. [Earth Sci.] 32.1-12.

Merian,P. (1821): Uebersicht der Beschaffenheit der Gebirgsbildungen in den Umgebungen von Basel, mit besonderer Hinsicht auf das Juragebirge im Allgemeinen. Beiträge zur Geognosic, 1, 1-156.

MEyer, C.A. (1990): Sauropod tracks from the Upper Jurassic Reuchenette Formation (Kinmeridgian: Lonmiswil. KI. Solothurn) of northern Switzerland. Eclogac geol. Helv. 83,389-397.

MnLLe. A (1968): Die Subfamilie Euaspidoceratinae SpAH (Ammonoidea). Morphologic. Taxionomic, Stratigraphic. Phylogenie $\mathrm{Ph}$. D. thesis, Univ, Tübingen, $169 \mathrm{p}$.

Miluman, J. D., Freil.e. D. Steinex, R.P. \& Wilaer, R. J. (1993): Great Bahama Bank aragonitic muds; mostly inorganically precipitated mostly cxported. J. scd. Petrol. 63/4,589-595.

Motsch, C. (1863): Vorlatufiger Bericht uber die Ergebnisse der im Sommer 1862 ausgeführten Untersuchungen im Weissen Jura der Kantone Solothurn und Bern. Verh. sehweiz. natf. Ges. Luzern 1862 $156-168$

Mozsch. C. (1867): Geologische Beschreibung des Aargauer Jura und der nördlichen Gebiete des Kantons Zürich. Beitr. geol. Karte Schweiz 4, 1-319.

Morfus. N. J. (1968): Stratigraphical and palacontological researches in the Upper Jurassic rocks, Unpubl. Ph. D. thesis, Univ, Oxford, 234 p.

Movchet, P. (1995): Le Kimméridgien du Jura central. Mierofaciès. Minéralogie et interprétation séquentielle. Ph. D. thesis. Univ. Neuchâtel, $204 \mathrm{p}$.

MoUterde, R., ENAY, R., CARIOU, E., Contint, D., Elmi, S., Gabiliy, J., Mangold, C. Mattel, J. Rioult, M. Thierky, I. \& Tivtant, H. 
(1971): Les zones du Jurassique en France. C.R. Soc. géol. France $1971,6,76-102$.

Muluns, H.T. \& Netumann, A. C. (1979): Deep carbonate bank margin structure and sedimentation in the northern Bahamas. $m$ : Dovie, S. J. \& PrLKey, O.H. (eds.) Geology of continental slopes Spec. Publ. Soc. econ. Paleont. Mineral. 27.165-192.

Munier-Chalmas, M. (1892): Sur la possibilité d'admettre un dimorphisme sexuel chez les Ammonoidés. C R. somm. Séances Soc. géol. France (3). 20/14, 170-174

Murr. M. (1994): Association of tepees and palacokarst in the Ladinian Calcare Rosso (Southern Alps, Italy). Sedimentology 41 , $621-641$

Neumann, A.C. (1965): Processes of Recent carbonate sedimentation in Harrington Sound. Bermuda. Bull. marine Sci. 15/4, 987-1035.

NikimiN, S. N. (1916): Cephalopoden des Moskauer Jura. Mém. Com. géol. St. Petersb [N.S.] 70, 1-61.

OGDEN, J.C. (1977): Carbonate-sediment production by parrot fish and sea urchins on Caribbean Reefs. In:Frost,S. H. Weiss, M. P. \& SAUNDERS, J. B. (eds.): Reefs and related carbonate-ecology and sedimentology. Amer. Assoc. Petroleum Geol., Studies in Geology 4. $281-288$

OPPEL.A. (1856-58): Die Juraformation Englands, Frankreichs und des sudwestlichen Deutschlands. Jh. wurtlemb. natw. Ver. 12-14,1-857.

OPPEL, A. (1862 - 63): Ueber jurassische Cephalopoden. Palacont. Mitt. Mus. k. bayer. Staat $1 / 3,127-266$.

OPPEL, A.\& WASGEN, W. (1866): Über die Zone des Ammonites transversarius Geognost-palăont. Beitr. 1/2, 206-316.

Oraıny. A. D' (1842-1851): Paléontologic française, Terrains oolithiques ou jurassiques, I Céphalopodes. Cosson, Paris, $642 \mathrm{p}$.

PAGE, K. N. (1991): Ammonites. Ir: Makmi., D M \& HLDSON, ID (eds): Fossils of the Oxford Clay (p. 86-143). Palaeont. Assoc. field guide to fossils 4 . London, $286 \mathrm{p}$.

PALFRAMAN, D. F, B. (1966): Variation and ontogeny of some Oxfordian ammonites: Taranelliceras richei (DE LORIOL) and Creniceras renggeri (OPPEL), from Woodham, Buckinghamshire. Palacontology 9. $290-311$.

Persoz. F. (1982): Inventaire minéralogique, diagenèse des argiles et minéralostratigraphie des séries jurassiques et crétacées inférieures du Plateau suisse et de la bordure sud-est du Jura entre les lacs d'Annecy et de Constance. Matér. Carte géol. Suisse [N. S] 155. $1-52$.

Prasoz. F \& Remane, I (1976): Minéralogic et géochimie des formations à la limite Jurassique-Crétacé dans le Jura et le Bassin vocontien. Eclogae geol. Helv. 69/1, 1-38.

Pemimclerc, P. (1922): Sur une rhynchonelle de l'Oxfordien supérieur de la Pologne ct du Poitou. Bon, Vesoul, $14 \mathrm{p}$.

Perruoun, F.J. (1957): Sedimentary rocks, 2nd ed. Harper \& Brothers, New York, $718 \mathrm{p}$.

PFirter, U. (1982): Zur Lithostratigraphic und Tektonik der Raimeux Antiklinale (Kt. Bern, Kt. Jura). Unpublished Ph. D. thesis, Univ Basel, 118 p

Prounder, V.R. \& Wickert, H. (1970): Einige Versuche über den Einfluss der chemischen Zusammensetzung und der Mahlung auf die Sinterung von Zement-Rohmehlen. Zement-Kalk-Gips 4, 147-151.

Prrter, B. (1996): Contrôles climatiques, eustatiques et tectoniques sur des systèmes mixtes carbonates-siliciclastiques de plate-forme: $\mathrm{ex}$ emples de IOxfordien (Jura suisse, Normandie, Espagne). Ph.D thesis, Univ. Fribourg, 246 p.

Playford, P. E. \& Cockhain, A. E. (1969): Algal stromatolites: Deepwater forms in the Devonian of Western Australia. Seience 165/3897, $1008-1010$.

PUMPIN, V.F. (1965): Rifrsedimentologische Untersuchungen im Rauracien von St. Ursanne und Umgebung (zentraler Schweizer Jura) Eclogae geol. Helv. 58/2, 799-876.

PURSER, B. (1979): Middle Jurassic sedimentation on the Burgundy platform. Assoc. Séd. francais, Publ spéc. 1,75-84

Ouensiedr, F. A. (1849): Dic Cephalopoden (with atlas). Fues, Tubin gen. $580 \mathrm{p}$.

QUENSIEDT, F. A. (1887-1888): Die Ammoniten des Schwäbischen Jura. Vol. 3 (p. 816-1140). Der Weissse Jura, with atlas. Schweizerbart, Stuttgart.

ReINECKE, J. M. C. (1818): Maris protogaei Naurilos et A rgonautas vulgo Cornua Ammonis in agro Coburgico et vicino reperiundos Ahl. Coburg. $90 \mathrm{p}$.
ReITNER, J. \& NeUweLLER, F., coord. (1995): Mud mounds: A polygenetic spectrum of fine-grained carbonate buildups. Facies $32,1-70$.

RENZ, O. (1931): Über das Vorkommen von Cladocoropsiskalken im Schweizer-Jura. Abh. schweiz. paläont. Ges. 51,1-4.

RIAZ,A. DE (1898): Description des ammonites des couches à Peltoceras transversarium (Oxfordien supérieur) de Trept (Isère). Masson, Paris, $69 \mathrm{p}$.

RoввıNS, L. L. \& BLAckwELDER. P. L. (1992): Biochemical and ultrastructural evidence for the origin of whitings: A biologically induced calcium carbonate precipitation mechanism. Geology 20/5,464-468.

RoLlier, L. (1888): Etude stratigraphique sur le Jura bernois Les faciès du Malm jurassicn. Arch. Sci. phys nat. Genève [3] 19, 1-85. Eclogae geol. Helv. 1, 1-88.

RoLlier, L. (1892): Sur la composition et l'extension du Rauracien dans le Jura. Fclogac geol. Helv. 3/3, 271-293.

Rollier. L (1893a): Structure et histoire géologiques de la partie du Jura central comprise entre le Doubs (Chaux-de Fonds), le val de Delémont, le lac de Neuchâtel et le Weissenstein. Matér. carte géol. Suisse 8, ler Suppl., 1-286.

Roliter. L. (1893b): Sur la composition et l'extension du Rauracien dans le Jura. Areh. Sci. phys. nat. (Geneve), [3] 29,51-73.

Roltier, L. (1898): Deuxième supplément à la description géologique de la Suisse au 1:100000. Matér. carte géol. Suisse [n. s.] 8, 1-206.

RoL.uer, L. (1911): Les facies du Dogger ou Oolithique dans le Jura et les régions voisines. Georg. Genève et Bale, $352 \mathrm{p}$.

RoMAN, F. (1938): Les ammonites jurassiques et crétacécs. Essai de genera. Masson, Paris, 554 p.

RonchadzE, J. (1917): Perisphinctes de l'Argovien de Chézery et de la Faucille. Mém. Soci paléont. suisse 43,1-70.

RothPLETz, W. (1933); Geologische Beschreibung der Umgebung von Tavannes im Berner Jura. Verh. natf. Ges. Basel 43, 12-150.

Smmatss, D. \& Jones, M. (1993): Quantified Middle Jurassic to Paleocene eustatic variations based on Russian Platform stratigraphy: Stage level resolution. Bull. geol. Soc. Amer. 105/8,1109-1118.

SALFELD. H. (1913): Die Gliedcrung des oberen Jura in Nordwesteuropa. N. Jb. Mineral. Geol. Palänt., Beilbd. 37/1, 125-246.

SALfELD, H. (1914): Utber einige stratigraphisch wichtige und cinige scltene Arten der Gattung Perisphinctes aus dem oberen Jura Nordwestdeutschlands. Jber. niedersächs, geol. Ver. 7, 231-251.

SAt rfu, H. (1915): Monographie der Gattung Cardioceras Nrumarr et Unuo. Z. dtsch. geol. Ges. 67. Abh. 3, 147-204.

SALFELD, H. (1917): Monographie der Gattung Ringsteadia (gen. nov.). Palaeontographica 62/2, 69-84

Sapunov. I. G. (1973): Ammonites de l'Oxfordien de la partie occidentale des Hauts Plateaux (Algérie). Publ. Serv, géol. Algérie [N, S.] Bull, 44, 101-137.

SAPUNOV, I. G. (1976): Ammonite stratigraphy of the Upper Jurassic in Bulgaria II. Oxfordian: Substages, Zones and Subzones. Geologica balcanica $6 / 4,19-36$

Sapunov. L. G. (1979): Ammonoidea. In: Tsankov. V. (ed.); Les fossiles de Bulgarie 111/3. Acad. bulgare Sci., Sofia, $237 p$.

SARTI, C. (1985): Biostratigraphie et faune a ammonites du Jurassique supérieur de la plate-forme atésine (Formation du Rosso ammonitico véronais). Rev. Paléobiologie 4/2,321-330.

Schairer, G. (1970): Quantitative Untersuchungen an Sutneria platynota (Reintcke) (Perisphinetidae, Ammonoidea) der fränkischen Alb (Bayem). Mitt. bayer. Staatslg. Paläont. hist. Gicol. 10. $153-174$

Schairr., G. (1983): Die Cephalopodenfauna der Schwammkalke von Biburg (Oberoxford, sudliche Frankenatb): Taramelliceras Mitt. bayer. Staatsslg, Palăont. hist. Geol. 23, 35-49.

Scharer, G. (1989): Dic Ccphalopodenfauna der Schwammkalke von Biburg (Oberoxford, siidliche Frankenalb): Idoceratinae (Ammonitina). Munchner geowiss. Abh. [A] 15,97-138.

Sснӓв, U, (1967): Geologische und sedimentpetrographische Untersuchungen im Mesozoikum und Tertiär des Bielerseegebietes (Kt. Bern). Beitr, geol. Karte Schweiz [N, F] 133,1-88

Schlampp, V. (1991): Malm-Ammoniten. Ein Bestimmungsatlas. Goldschneck-Verlag, Korb, 184 p.

SCHLEGELMIICH, R. (1994): Die Ammoniten des suddeutschen Malms. Fischer, Stuttgart, $297 \mathrm{p}$.

SCHMIDT-KALER, H. (1962): Stratigraphische und tektonische Untersuchungen im Malm des nordöstlichen Ries-Rahmens. Erlanger geol. Abh. 44, 1-51 
Scuneider, A. (1960): Geologie des Gebietes von Siegfriedblatt Porrentruy (Berner Jura). Beitr. geol. Karte Schweiz [N, F.] 109, 1-72.

Scuwergek, Q. (1995): Zum Auftreten der Ammonitenarten Amoeboceras bauhini (Orret) und Amocboceras schuiginae Mrserhnikon im Oberjura der Schwabischen Alb. Jh. Ges. Naturkde. Wüttemberg 151,171-184.

Schweigekt, G. \& Callomon, J.H. (1997): Der bauhini- Faunenhorizont and seine Bedeutung für die Korrelation zwischen tethyalem und subborealem Oberjura. Stuttgarter Beitr. Naturk. [Ser. B] 247. $1-69$.

Scofmis, T. P., Stearn, C. W., Boucher, D. Fryde, P., Hawkins, C.M., Hunter, L. G. \& MacGeschy, J. K. (1980): Calcium carbonate budget of a fringing reef on the west coast of Barbados. Part 2 - Erosion, sediments and internal structure. Bull. marinc Sci. 30/2, 475-508.

Sequeinos, L. (1974): Paleobiogeografia del Calloviense y Oxfordiense en el sector central de la zona subbetica. Ph. D thesis Univ. Granada, Granada. Vol. 1:275 p., vol. 2:361 p.

SEqueIros, L. (1977): Oxfordian ammonite genus Passendorferia Brochwicz-Lewinski, 1973, from Malaga (Subbetic zone, Spain). Acta geol. pol. 27/3.357-368.

SHIN, E. A., SHEINEN, R. P, LIDZ, B. H. \& SWART, P. K. (1989): Whitings, a sedimentologic dilemma. J. sed, Petrol. 59/1,147-161.

Saegraikd, P. (1952): Die Heersumer Schichten im Hildesheimer JuraZug. Geol. Jb. 67, 273-359.

Sifmiranzxi, J. (1891): Fauna kopalna warstw oxfordzkich i kimerydzkich w okregu krakowskim i przyleglych czesciach Krolestwa Polskiego. Akad. Umiejet. Krakovie. 18, 1-92.

SAEMIRADZKI, J. (1898-99): Monographische Beschreibung der Ammonitengattung Perisphinctes. Palaeontographica $45,69-360$.

SPATH, L.F. (1925): On the collection of fossils and rocks from Somaliland made by Messrs. B. K.N. Wyllie, B.Sc., F.G.S., and W. R. Smellie, D.Sc., F.R.S.Ed., Part VII: Ammonites and Aptychi. Monogr. ged. Dept. Hunterian Mus, Glasoow Univ, 1, 111-164

Stakhin, P. (1924): Geologie der Juraketten bei Welschenrohr. Beitr. geol. Karte Schweiz [N. F.] 55/1,1-34.

Stampfu, G. M. (1993) Le Brianconnais. terrain exotique dans les Alpes? Eelogae geol. Helv. 86'1, 1-45,

Stגubue, A.J. (1959): Zur Stratigraphie des Callovian im zentralen Schweizer Jura. Edogae geol. Helv. 52/1, 57-176.

Srefa vov, J. (1962): Oxfordian ammonites from the family Aspidoceratidae in Bulgaria, Trav, Géol. Bulgarie [Sér. Paléontologie] 4, $95-125$.

Sthasser, A. \& Davaud, E. (1983): Black pebbles of the Purbeckian (Swiss and French Jura): lithology, gecchemistry and origin. Eclogae geol. Helv. 76/3,551-580.

Sykes, R.M. \& Callomon, J.H. (1979): The Amocboceras zonation of the boreal Upper Oxfordian. Palacontology 22/4, 839-903.

Svkes, R. M. \& SURIYk. F. (1976): A revised ammonite zonation of the Boreal Oxfordian and its application in northeast Greenland. Lethaia $9,421-436$.

Szunczewski, M. (1968): Stromatolity jurajskie w Polsce. Acta geol. pol. $18,1-99$.

TARKOWSKI, R. (1984): Biostratigraphie ammonitique de I'Oxfordien in férieur et moyen des environs de Cracovie. Zeszyty Nauk. Akad. gorn.-hutn. Stan. Stas. Krakowic, Kwart., Gcologia 1983, 9/2.5-80.

ThaLmaNn, H.K. (1966): Zur Stratigraphie des oberen Malm im südlichen Berner und Solothurner Jura. Mitt. natf, Ges, Solothurn $22,4-125$.

Thirzu, M.E. (1830): Notice sur le terrain Jurassique du Département de la Haute-Saône. Mém. Soc. Hist nat. Strasbourg 1, 1-40.

Thurmann, J, (1830): Essai sur les soulèyemens Jurassiques du Porrentruy. Mèm. Soc. Hist. nat. Strasbourg 1,1-84.

Thurmans, J. \& Etalion, A. (1861-64): Lethea bruntrutana ou études paléontologiques et stratigraphiques sur le Jura bernois et en particulier sur les environs de Porrentruy. N. Mém. Soc. helv. Sei. nat. $18-20,1-500$

Trvtast, H. (1958): Sur la stratigraphie de l'Oxfordien supérieur aux environs de Dijon (Cote dOr). C.R. Acad. Sci. (Paris) 246114 $2504-2507$

Tintant. H. (1959): Etudes sur les ammonites de l'Oxfordien supérieur de Bourgogne. 1 - Les genres Plarysphinctes nov. et Larcherio nov. Bull. scient. Bourgogne 19, 109-144.
Touler, A. (1905): Tabellarische Zusammenstellung der Schichtfolge in der Umgebung von Basel. Basel, 8 p.

TRACEY, I. I., LADD, H. S. \& HOFFmeIsteR. J.E. (1948): Reefs of Bikini, Marshall Islandk Bull. geol. Soc. America 59. 861-878.

Trizolet, M. De (1872): Notice géologique sur le Mont-Châtelu. Essai de synchronisme entre les terrains du Jura argovien et ceux de la Suisse occidentale. Bull. Soc. Sci. nat. Neuchấtel 9, 267-295.

Tschopp, R. (1960): Gcologie des Gebietes von Sicgfriedblatt Miécourt (Berner Jura). Beitr. geol. Karte Schweiz [N, F.] 110, 1-62.

Tschum, P. (1983) Geologische Untersuchungen in der WeissensteinKette westlich der Klus von Balsthal (von Oensingen bis Oberbipp). Unpublished licentiate thesis Univ. Bern. 118 p.

WEGELE. L. (1929): Stratigraphische und faunistische Untersuchungen im Oberoxford und Unterkimmeridge Mittelfrankens. Palkontologischer Teil. Palaeontographica 72, 1-94

WIEDENMAYER, C. (1923): Geologie der Juraketten zwisehen Balsthal und Wangen a. A.. Beitr. geol. Karle Schweiz [N. F.] 48/3, 1-37.

WierzBowski. A. (1965): Sur la limite entre l'Oxfordien et le Kimméridgien dans la partie septentrionale du Jura de Cracovie et de Czestochowa. Ann. Soc. géol. Pol. 35/2, 291-300.

Wiekz вowski.A. (1991): Biostratigraphical correlations around the $\mathrm{Ox}$ fordian/Kimmeridgian boundary. Acta geol. pol. 41, 149-155.

Wildi. W. Funk, H., Loup, B., A mato, E. \& Huggenherger, P. (1989): Mesocoic subsidence history of the European marginal shelves of the alpine Tethys (Helvetic realm. Swiss Plateau and Jura). Eclogae geol. Helv. $82 / 3,817-840$.

Wright. J. K. (1983): The Lower Oxfordian of North Yorkshire. Proc. Yorkshire geol. Soc. 44/3, no. 19, 249-281.

WU, X. (1989): Carnian (Upper Triassic) sponge mounds of the northwestern Sichuan Basin, China: Stratigraphy, facies and paleoecology. Facies 21.171-188.

WURTENaERger, F. J. \& WURTENBehger, L. (1866): Der weisse Jura im Klettgau und angrenzenden Randengebirg. Verh. natw. Ver. Karlsruhe $2,11-68$.

Zesss, A. (1955): Zur Stratigraphie des Callovien und Unter-Oxfordien bef Blumberg (Stidbaden). Jh. geol. Landesamt Bad.-Württemb. 1. $239-266$.

Zeıss, A. (1965): Exkursion in den MaIm der suidwestlichen Frankenalb. Geol. BL NO-Bayern 15/2, 90-102.

Zieglek. B. (1957): Creniceras deritaten [Ammonitacea] im MittelMalm Sadwestdeutschlands, N. Jb. Geol. Paläont. [Mh.] 1956/12, $553-575$.

ZIEGLER, B. (1959): Idoceras und verwandte Ammoniten-Gattungen im Oberjura Schwabens, Eclogae geol. Helv, 52/1, 19-56.

ZiegLeR, B. (1963a): Ammoniten als Faziesfossilien. Paldont. Z. 37, $96-102$.

ZIEGLER, B. (1963b): Leitfossilien und Faziesfossilien. Vjschr, natf. Ges Zuirich $108 / 3,217-242$

Ziegler, B. (1964): Das untere Kimeridgien in Europa. Colloque du Jurassique 1962, Vol. C. rend. Mém., 345-354. Inst. grand-ducal, Sect.Sci.nat., phys, mathém., Luxembourg.

Ziegler, B. (1967). Ammoniten-Okologie am Beispiel des Oberjura. Geol. Rdsch. $56,439-464$.

ZIEGLER, B. (1977): The "White" (Upper) Jurassic in Southern Germany. Stuttg. Beitr. Natkd. [B] 26, 1-79.

ZIEGLER, B. (1981): Ammonoid biostratigraphy and provincialism: Jurassic-Old World. In: House, M. R. \& SENIOR, J. R.,(eds): The Ammonoidea. The evolution, classification, mode of life and geological usefulness of a major fossil group. Systematics Assoc. spec. Vol. 18, p. 433-457. Academic Press London.

Ziegler, B. (1987): Der Weisse Jura der Schwäbischen Alb. Stuttgarter Beitr. Natkde. [Ser. C] 23,1-71.

ZIEGLER, M. A. (1962): Beitrăge zur Kenninis des unteren Malm im zentralen Schweizer Jura. Ph. D. thesis, Univ, Zürich, 51 p.

ZiEgLer, P.A. (1956): Zur Stratigraphie des Séquanien im zentralen Schweizer Jura. Mit einem Beitrag von E. GAschE. Beitr. geol. Karte Schweiz [N.F.] 102, 37-101.

ZueqLer, P. A. (1982): Geological atlas of Western and Central Europe. Shell. Internat. Petroleum Maatsch. Elsevier, Amsterdam. $130 \mathrm{p}$.

Ziegl.ER, P. A. (1988): Evolution of the Aretic-North Atlantic and the Western Tethys. Mem. Amer. Assoc. Petrol. Geol.43. Tulsa. 198 p. 
Fig. 1 - Quenstedtoceras lamberti lamberti (SowERBy), Lamberti Zone, Lamberti Subzone, Schellenbrücke Bed, section RG 60, bed 3, Eisengraben, Gansingen AG. Complete adult with peristome. J 31715 , lcg. R. Enay, $\times 1$.

Fig. 2-Cardioceras (Scarburgiceras) paticicostatum LaNGE, Lamberti Zone, uppermost Lamberti Subzone, iron oolitic marly clay of the upper Herznach Formation, section RG 280, lower part of bed 6, clay pit of Ampthil, Liesberg BL.J 31219 , leg. R. Gygi, x1.

Fig. 3 - Cardioceras (Scarburgiceras) scarburgense (Young \& Bird), Mariae Zone, Scarburgense Subzone, lower Renggeri Member, $1.2 \mathrm{~m}$ above the base, section RG 280, bed 7, clay pit of Ampthil, Liesberg BL. J 31103, leg. R. \& S. Gygi, X 1.

Fig. 4-Cardioceras (Scarburgiceras) scarburgense (Young \& Bıro). Mariac Zone, Scarburgense Subzone, lower Renggeri Member, $1.5 \mathrm{~m}$ above the base, section RG 280, bed 7, clay pit of Ampthil, Liesberg BL. J 31104, leg. R. \& S. Gygi, x 1 .

Fig. 5 - Cardioceras (Scarburgiceras) scarburgense (Younc \& BiRD), Mariae Zone, Scarburgense Subzone, lower Renggeri Member, clay pit of Ampthil, Liesberg BL. J 31229, leg. K. Lüdin, $\times 1$.

Fig, 6-Creniceras renggeri (OPPEL), Mariae Zone, Scarburgense Subzone, lower Renggeri Member, clay pit of Ampthil, Liesberg BL. J 31089 , leg. H. Zbinden, $\times 1$.

Fig. 7 - Creniceras renggeri (OPPEL), Mariae Zone, Scarburgense Subzone, lower Renggeri Member, section RG 280, bed 7, $2 \mathrm{~m}$ above the base, clay pit of Ampthil, Liesberg BL. J 31117, leg. R. \& S. Gygi, × 2.

Fig. 8 - Cardioceras (Scarburgiceras) praecordatum Douvilte, Mariae Zone. Praecordatum Subzone, lower Renggeri Member. section RG 280, bed 7,3.5 m above the base, clay pit of Ampthil, Liesberg BL. J 31114, leg. R. \& S. Gygi. $\times 1$.

Fig. 9 - Cardioceras (Scarburgiceras) praecordatum Douvıle, Mariae Zone, Praecordatum Subzone, Renggeri Member, section RG 280 , bed $7,27 \mathrm{~m}$ above the base, clay pit of Ampthil, Liesberg BL.J 30949, leg. R. Himmler, $\times 1$.

Fig. 10 - Cardioceras (Pavloviceras) cf. mariae (D'Oraıny), Mariae Zone, Scarburgense Subzone, not in silu, Herznach Formation, iron mine of Herznach AG. J 25206, leg. R. Eichin, × 1.

Fig. 11 - Cardiocerus (Scarburgiceras) bukowskii MAIrE, Cordatum Zone, Bukowskii Subzone, not in situ, Renggeri Member in a creek northwest of La Cornée. Rebévelier JU. J 30948, leg. B. Lange, $\times 1$. 

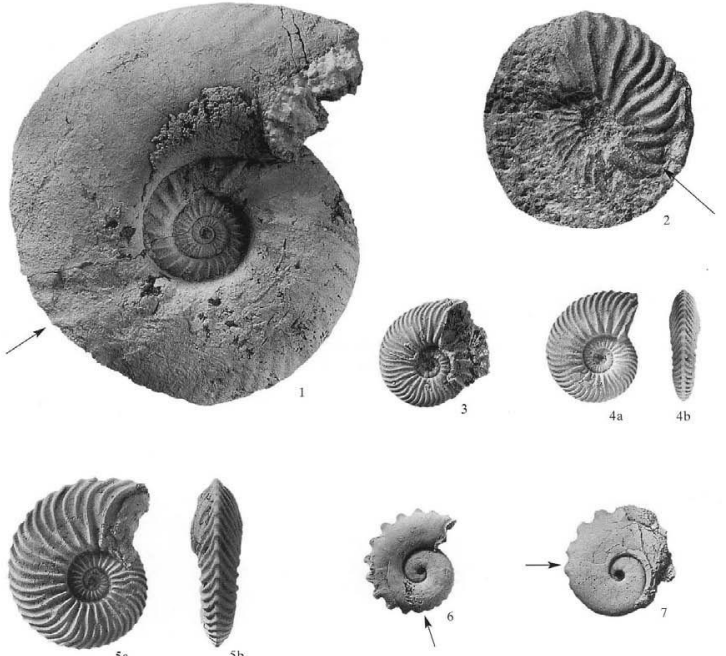

$5 a$

$5 b$
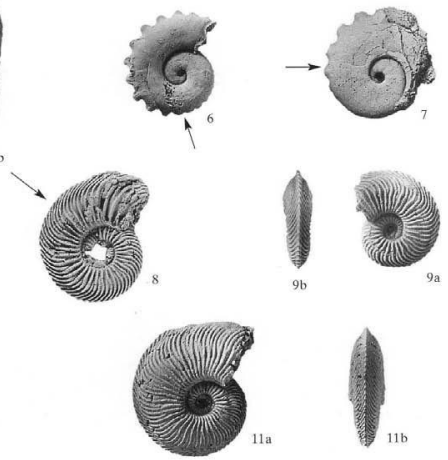
Plate 2

Fig. 1 - Cardioceras (Cardioceras) costicardia vulgare A kekel, Cordatum Zone, Costicardia Subzone, upper Renggeri Member. out of a creek northwest of La Cornée, Rebévelier JU.J 31646 , leg. B. Hostettler, $\times 1$.

Fig. 2 - Cardioceras (Subveriebriceras) costellanum Buckman, Cordatum Zone, Costicardia Subzone, upper Renggeri Member, Bollement, St-Brais JU.J 31648, leg. B. Hostettler, x 1.

Fig.3-Cardioceras (Cardioceras) cordatum (SowerBy), Cordatum Zone, Cordatum Subzone, Glaukonitsandmergel Bed, section RG 207, bed 14a, excavation near water conduit in Churz Tal, Siblingen SH. J 23027, leg. R. \& S. Gygi, × 1 .

Fig. 4 - Cardioceras (Cardioceras) persecans (Buckmas), Cordatum Zone, Cordatum Subzone, Schellenbrücke Bed, upper Herznach Formation, section RG 208, bed 9, excavation on Brunnrain, Ueken AG. J 24982, leg. R. \& S. Gygi, × 1.

Fig. 5 - Cardioceras (Cardioceras) cf. stella ARKELL, Cordatum Zone, Cordatum Subzone, Schellenbrücke Bed, upper Herznach Formation, section RG 209, bed 7, iron mine, Strecke III under Hübstel hill, Herznach AG. J 25184, leg. R. Gygi, x 1.

Fig.6 - Perisphinctes (Otosphinctes) patsurattensis DE Loriol, Cordatum Zone, Cordatum Subzone, Schellenbrüicke Bed, upper Herznach Formation, section RG 208, bed 9, excavation on Brunnrain, Ueken AG. J 23277, leg. R. \& S. Gygi, x 1.

Fig. 7 -Cardioceras (Subvertebriceras) densiplicatum Boden, Transversarium Zone, Densiplicatum Subzone, Mumienmergel Bed. section RG 212, bed 7, excavation above shooting range in Churz Tal, Siblingen SH. J 23045, leg, R. \& S. Gygi. × 1 .

Fig. 8-Protophites christoli (BEAudoun), Cordatum Zone, Cordatum Subzone, Schellenbricke Bed, upper Herznach Formation. section RG 208, bed 9, excavation on Brunnrain, Ueken AG. J 24943, leg. R. \& S. Gygi, × 1.

Fig. 9 - Neoprionoceras delnontanum (OpPEL), Cordatum Zonc, Cordatum Subzonc. Schellenbrucke Bed, Herznach Formation. section RG 208, bed 9, excavation on Brunnrain, Ueken AG. J 25052, leg. R.\& S. Gygi, × 1.

Fig. 10 - Cardiocenes (Miticardioceras) tenuiserratum (Oppe1), Transversarium Zone, upper Antecedens or lower Laciaeformis Subzone, lower Birmenstorf Member, section RG 208, bed 12 or further above, excavation on Brunnrain, Ueken AG. J 25158 , leg. R. \& S. Gygi, $\times 2$.

Fig. 11 - Gregoryceras (Pseudogregoryceras) iteni. Jeanver, Cordatum Zone, Cordatum Subzone, not in situ, Herznach Formation. section RG 209, iron mine of Herznach AG.J 23048, leg. R. Eichin, $\times 1$.

Fig. 12 - Cardioceras (Maltoniceras) schellwieni Boden, Transversarium Zone, Antecedens Subzone, lower Mumienkalk Bed, section RG 207. bed 16 a, excavation near water conduit in Churz Tal. Siblingen SH. J 23029. Jeg. R. \& S. Gygi, x 1. 

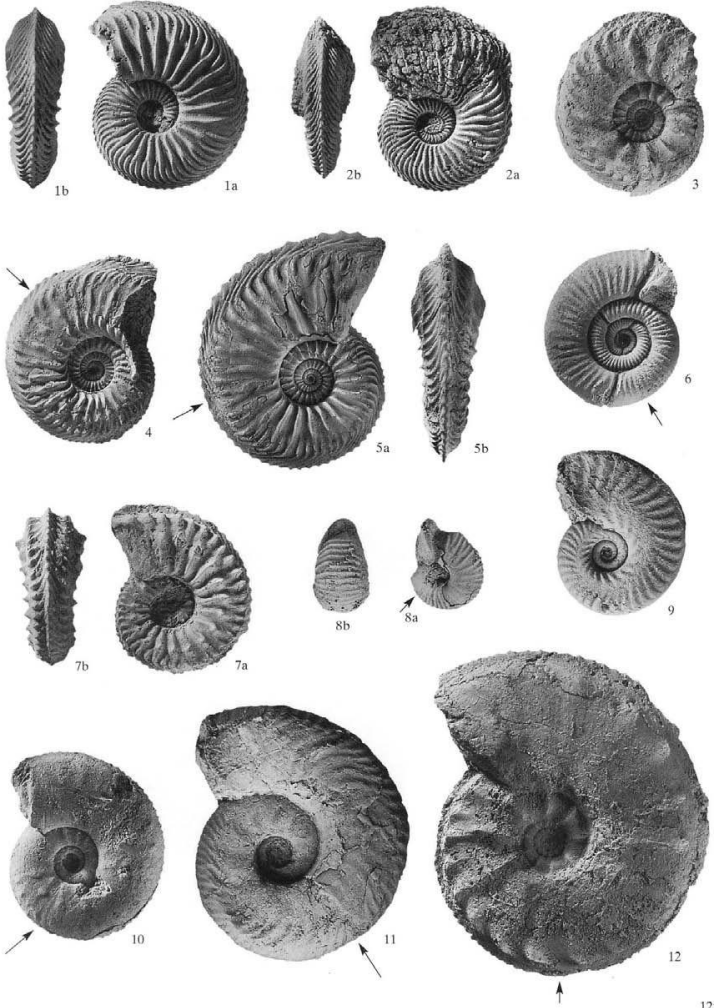
Fig. 1 - Perisphinctes (Arisphinctes) plicatilis (SowerBy), Transversarium Zone, Densiplicatum Subzone, Mumienmergel Bed, section RG 81 b, bed 13, excavation below Räckolterenbuck, Gachlingen SH. J 24633, leg, R. \& S. Gygi, × 1 .

Fig. 2-Perisphincles (Arisphinctes) helenae DE Riaz. Transversarium Zone, Antecedens Subzone, lower Mumienkalk Bed, section RG 81 b, bed 14a, excavation below Räckolterenbuck, Gächlingen SH. J 24575. leg. R. \& S. Gygi, × 1.

Fig. 3 - Ochetoceras (Ochetoceras) hispidum (OpPEL), Transversarium Zone, Antecedens Subzone. upper Mumienkalk Bed, section RG \$1b, bed 14b, excavation below Räckolterenbuck. Gächlingen SH. J 25901, leg. R. \& S. Gygi, x 1.

Fig. 4 - Perisphinctes (Dicholomosphinctes) antecedens SALfELD, Transversarium Zone. Antecedens Subzone, lower Mumienkalk Bed. section RG 207, bed 16a, excavation near water conduit in Churz Tal, Siblingen SH. J 24701, leg. R. \& S. Gygi. X 1.

Fig. 5 - Perisphinctes (Dichotomosphinctes) elisabethae DE RIAZ, Transversarium Zone, Antecedens Subzone, lower Mumienkalk Bed, section RG 81 b, bed 14a, excavation below Rackolterenbuck, Gächlingen SH. J 24528, leg. R. \& S. Gygi, × 1. 

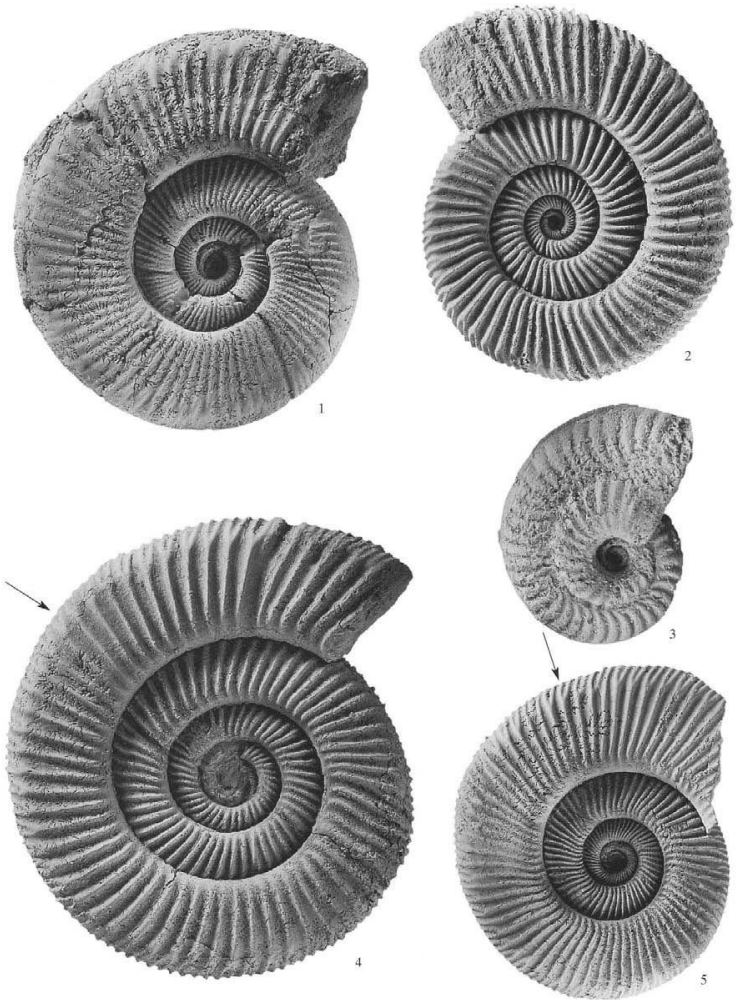
Fig. 1 -Gregoryceras (Gregoryceras) rransversarium (QuENSTEDT), Transversarium Zone, Antecedens Subzone, Mumienkalk Bed, Siblingen SH. J 28141, leg. P. Choffat, $\times 1$.

Fig. 2 - Gregoryceras (Gregoryceras) transversarium (QUENSIEDr), Transversarium Zone, Luciaeformis Subzone, upper Birmenstorf Member, section RG 230, excavation north of Eisengraben, Gansingen AG. J 23051, leg. R. \& S. Gygi; × 1 .

Fig. 3 - Gregoryceras (Gregoryceras) riazi (DE GrossouvRe), Transversarium Zone, Luciaeformis Subzone, upper Birmenstorf Member, section RG 230, excavation north of Eisengraben, Gansingen AG. J 23062, leg. R. \& S. Gygi, × 1 .

Fig. 4-Gregoryceras (Gregoryceras) temisculptum GyG1, refigured holotype, Transversarium Zone, Densiplicatum Subzone, Mumienmergel Bed, section RG 212, bed 7, excavation above the shooting range in Churz Tal, Siblingen SH.J 23064. leg. R. \& S. Gygi. $\times 1$.

Fig. 5-Gregoryceras (Psendogregoryceras) iteni JeANnET, Cordatum Zone, Cordatum Subzone, not in situ, Herznach Formation, section RG 209, iron mine of Herznach, Herznach AG. J 23048, leg. R. Eichin. × 1. 

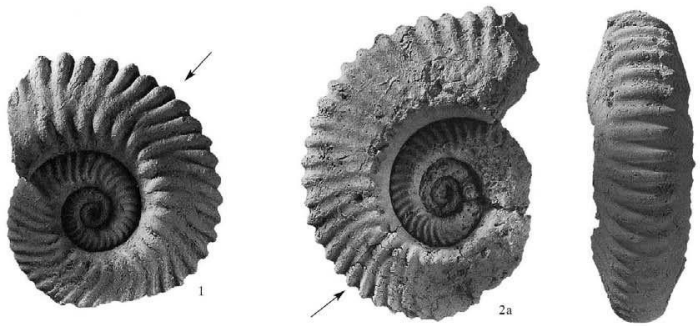

$2 b$
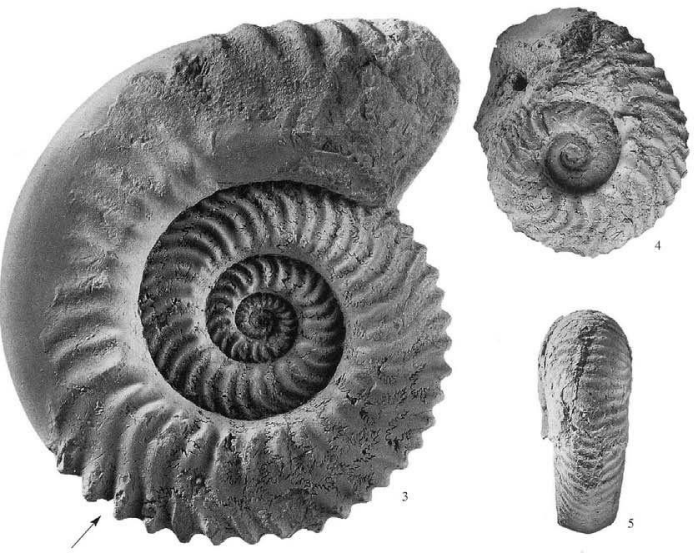
Fig. 1 - Subdiscosphinctes (Subdiscosphinctes) lucingae (FAvRE), Transversarium Zone, Luciaeformis Subzone, not in sittu, from a block fallen from the upper Birmenstorf Member, section RG 60, Eisengraben, Gansingen AG. J 23755, leg. J. Kaufmann, × 1.

Fig. 2-Passendorferia (Enayites) birmensdorfensis (Moesch). Transversarium Zone, Luciaeformis Subzone, Birmenstorf Member, section RG 32, bed 7, Schellenbrucke, Kattigen AG. J 31607. leg. F.J. Gscll, $\times 1$.

Fig. 3-Amoeboceras glosense (Bıgor \& BrasiL). Transversarium Zone, Luciacformis Subzone, Birmenstorf Member, section RG 276 , probably bed 32 . Chalch quarry, Holderbank AG. J 27679, leg. D. Krüger, $\times 1$.

Fig. 4 - Perisphinctes (Dichotomosphinctes) luciaeformis EnAy, Transversarium Zone, Luciacformis Subzone, lowermost glauconitic Effingen Member, section RG 212, bed 10, cxcavation above shooting range in Churz Tal, Siblingen SH. J 23652, leg. B. \& S. Gygi, $\times 1$.

Fig 5 - Larcheria cf. schilli (OPPEL), Bifureatus Zone, Schilli Subzone, lower Effingen Member, section RG 226, bed 47, road cut north of Jakobsberg quary, Veltheim AG. J 23539, leg. R. \& S. Gygi, x 1. 

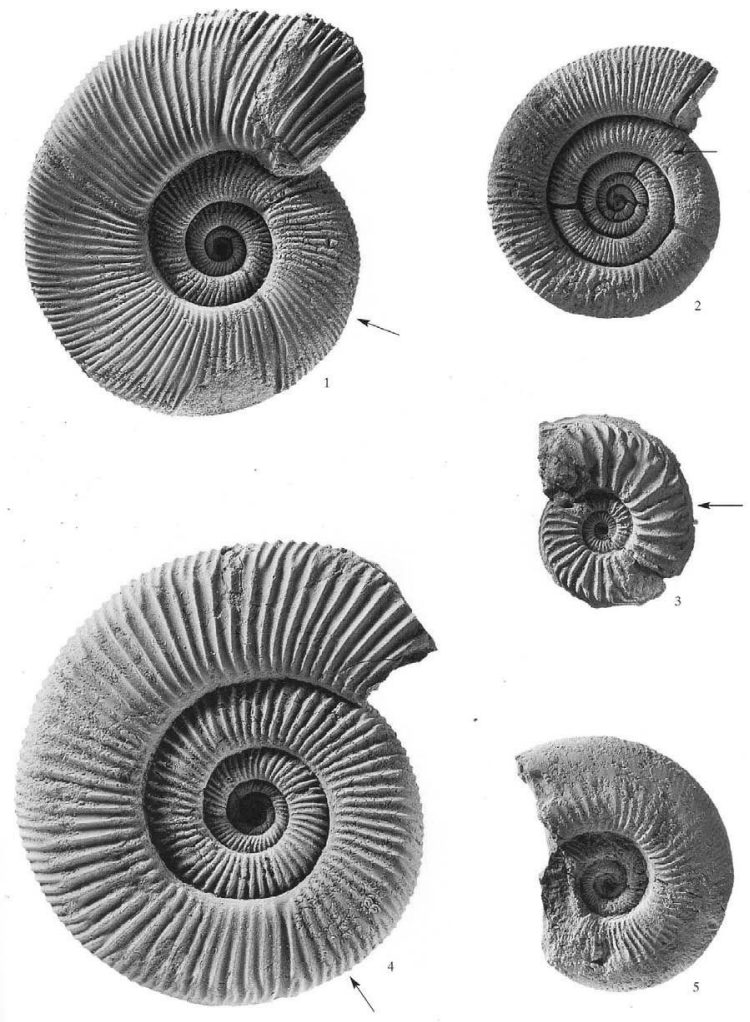
Plate 6

Fig. 1 - Passendorferia (Passendorferia) ziegleri (Brochwicz-LewINski), Transversarium Zone, Luciaeformis Subzone, upper Birmenstorf Member, section RG 230, excavation north of Eisengraben, Gansingen AG. J 24079, leg. R. \& S. Gygi, ×0.9. 


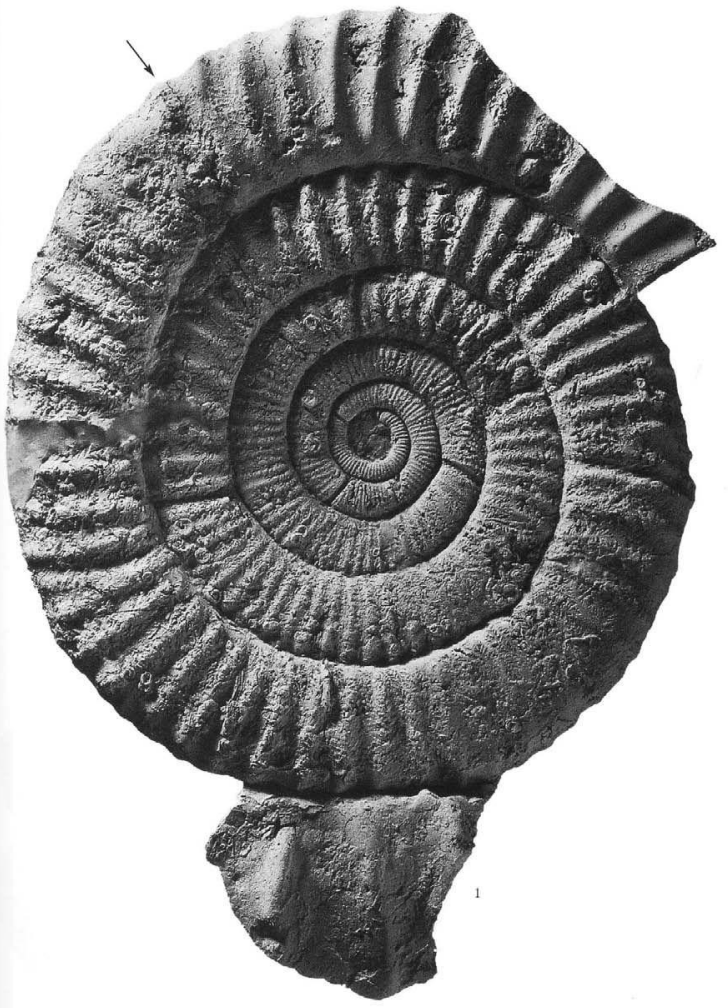


Fig. 1 - Subdiscosphincies (Aureimonianites) cracoviensis (SIEMIRADZKI), Transversarium Zone, Luciaeformis Subzone, upper Birmenstorf Member, section RG 230, excavation north of Eisengraben, Gansingen AG.J 23655, leg. R. \& S. Gygi, × 1 .

Fig. 2 - Taramelliceras (Proscaphites) anar (OPPEL), Transversarium Zone, Antecedens Subzone, upper Mumienkalk Bed, section RG 81 b, bed 14b, excavation below Räckolterenbuck, Gächlingen SH. J 25960, leg. R. \& S, Gygi, × 2.

Fig. 3 - Trimarginites stenorhynchus (OPPEL), Transversarium Zone, Luciaeformis Subzone, upper Birmenstorf Member, section RG 276, bed 34, Chalch quarry, Holderbank AG. Complete adult with peristome. J 27372, leg. R. Gygi, $\times 1$.

Fig. 4 - Trimarginites trimarginatus (OpPEL), Transversarium Zone, Antecedens Subzone, upper Mumienkalk Bed, section RG $81 b$, bed 14b, excavation below Räckolterenbuck, Gächlingen SH. Wholly septate. J 25924, leg. R. \& S. Gygi, × 1 . 


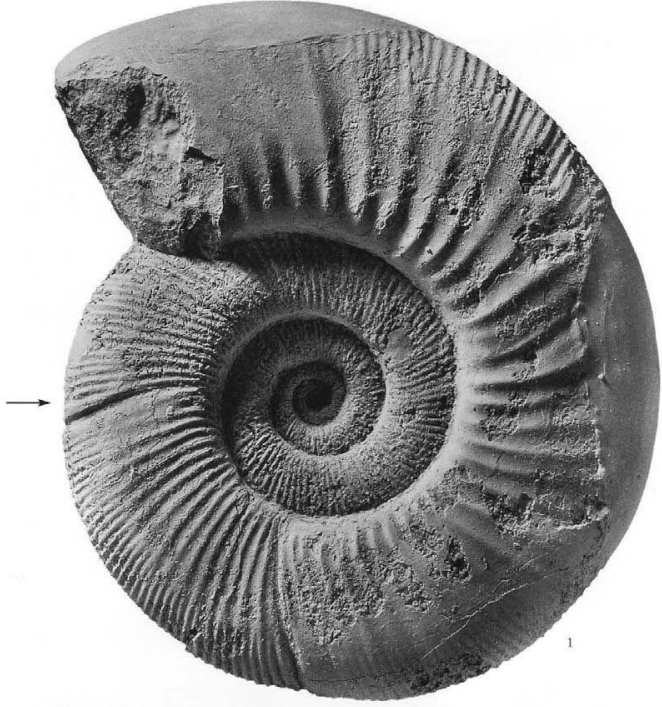

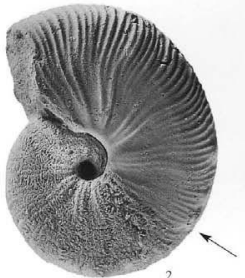

2
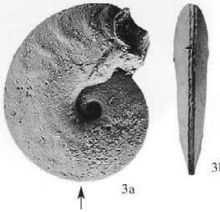

$3 b$

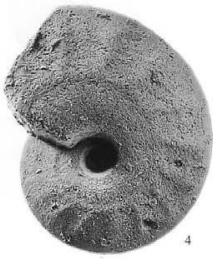


Plate 8

Fig. 1 - Perisphinctes (Oiosphinctes) siemiradzkii ENAY, Transversarium Zone, Luciaeformis Subzone, upper Birmenstorf Member, section RG 230, excavation north of Eisengraben, Gansingen AG. J 23656, leg. R. \& S. Gygi, $\times 1$.

Fig. 2 - Larcheria schilli (OpPEL), Bifurcatus Zone, Schilli Subzone, lowermost Effingen Member, section RG 226, not in silu, probably from bed 46, road cut north of Jakobsberg quarry, Veltheim AG. J 23534, leg. W. Ryf. × 1.

Fig. 3 - Perisphinctes (Dicholomoceras) cf. bifiarcatus (Quensiedt), Bifurcatus Zone, Stenocycloides Subzone, lower Effingen Member, section RG 226, bed $55,2.3 \mathrm{~m}$ above the base of the bed, road cut north of Jakobsberg quarry, Veltheim AG. J 23543, leg. W. Suter, $\times 1$.

Fig. 4-Amoeboceras cf. serratum (SowerBy), Bifurcatus Zone, probably Grossouvrei Subrone, Gerstenhübelkalk Beds, Effingen Member, quarry $500 \mathrm{~m}$ north of Mönthal AG. J 31456, leg. J. Haller \& R. Trümpy. x 2.

Fig. 5 - Subdiscosphinctes (Aurcimontanites) wojciechi n.sp., Transversarium Zone, Luciaeformis Subzone, upper Birmenstorf Member, section RG 230, excavation north of Eisengraben, Gansingen AG. J 23659, leg. R. \& S. Gygi, $\times 1$.

Fig. 6 - Perisphinctes (Neomorphoceras) chapuisi (OpPEL), Transversarium Zone, Antecedens Subzone, upper Mumienkalk Bed, section RG 207, bed 16b, excavation near water conduit in Churz Tal, Siblingen SH. J 26129, leg. R. \& S. Gygi, $\times 2$.

Fig. 7 - Perisphinctes (Neomorphoceras) collinii (OPPEL), Transversarium Zone, Luciaeformis Subzone, upper Birmenstorf Member, section RG 230, excavation north of Eisengraben. Gansingen AG. J 24170, leg. R. \& S. Gygi. × 1. 

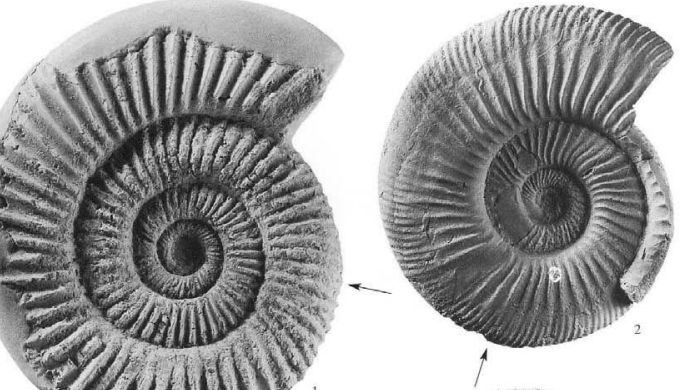

s yurion 3.t.

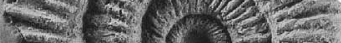

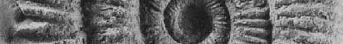

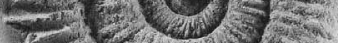

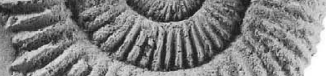
(2)ivilin.
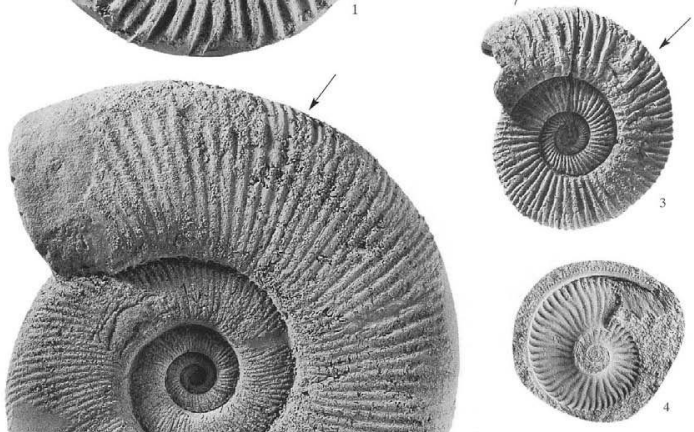

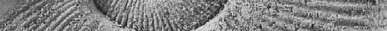
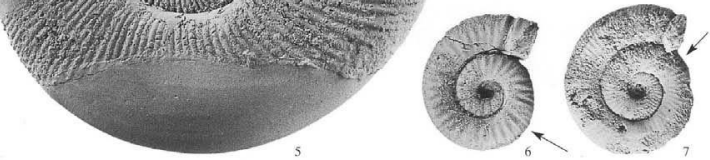
Plate 9

Fig. 1 - Perisphinctes (Dichotomoceras) rotoides RonchADzE, Bifurcatus Zone, Rotoides Subzone, lower Effingen Member, seetion RG 276, bed 46, Chalch quarry, Holderbank AG. 127971 , leg. R. Gygi, $\times 1$.

Fig. 2 - Perisphinctes (Dichotomoceras) bifurcatoides ENAY, Bifurcatus Zone. Stenocycloides Subzone, lower Effingen Member, section RG 276, bed 50, Chalch quarry, Holderbank AG. J 23704, leg. R. \& S. Gygi, $\times 1$.

Fig. 3 - Perisphinctes (Dichotomoceras) stenocycloides Sifmiradzxa, Bifurcatus Zone, Stenocycloides Subzone, lower Effingen Member, section RG 276, bed 50. Chalch quarry. Holderbank AG. J 23728, leg. R. \& S. Gygi, $\times 1$.

Fig. 4-Perisphinctes (Dichotomoceras) duongae Melendez, emend. Gygi, Bifurcatus Zone, Stenocycloides Subzone, lower Effingen Member, section RG 226, not in situ, road cut north of Jakobsberg quarry, Veltheim AG. J 23533, leg. H. Hess, X1. 

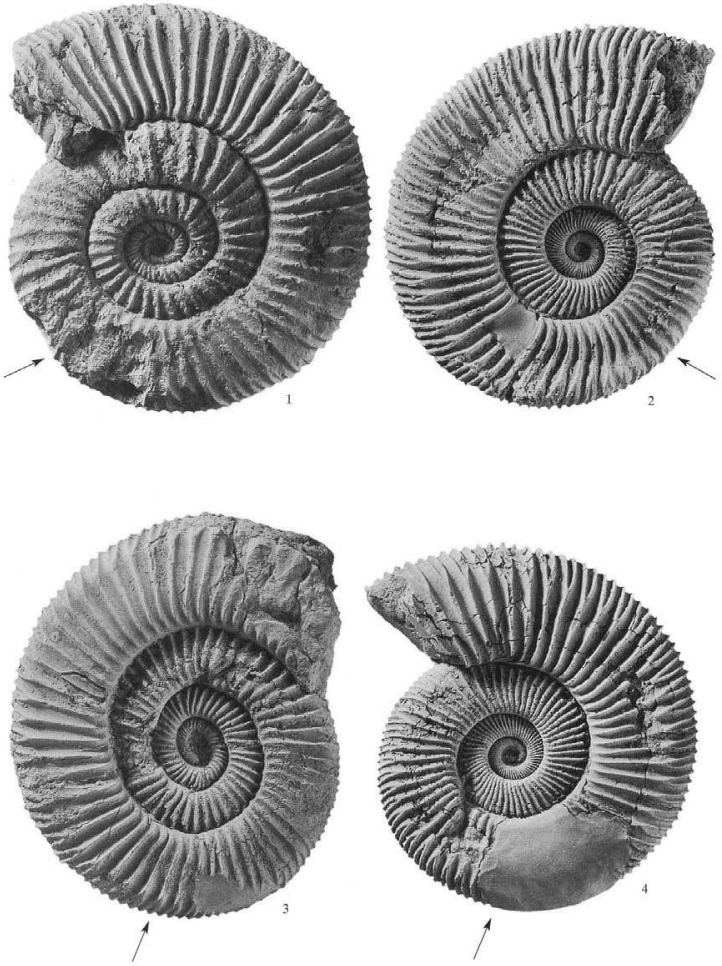
Fig. 1 - Euaspidoceras hypselium (OppeL), Bimammatum Zone, Hypselum Subzone, Effingen Member, section RG 37 , not in siut, fallen from the limestone succession 55-80 (sce Grol 1969, pl. 17), Jakobsberg quarry, Auenstein AG. J 27259, leg. D. Krüger, × 1.

Fig. 2 - Amoeboceras ovale (Quenstedr), Bimammatum Zone, Bimammatum Subzone, lower Crenularis Member, section RG 70. bed 6, large quarry, Mellikon AG. J 25608, leg. W. Bühler, $\times 1$.

Fig. 3 - Amoeboceras uberculatoalternans (Nikmin), Bimammatum Zone, Bimammatum Subzone, Hornbuck Member, section RG 76, bed 11, Hornbuck near Riedern am Sand, Erzingen D (Unterklettgau). J 31462. leg. R. Gygi, $\times 2$.

Fig. 4-Epipeltoceras bimammatum (QUENSTEDT), Bimammatum Zone, Bimammatum Subzone, Hornbuck Member, section RG 76, bed 11. Hornbuck near Riedern am Sand. Erzingen D (Unterklettgau). J 32268, leg. R. Gygi, $\times 1$.

Fig. 5-Epipeltocenas cf. bimammatum (QueNSTEDr). Bimammatum Zone. Bimammatum Subzone, Crenularis Member, section RG 36 (unpublished), bed 31, Fahr quarry. Auenstein AG. J 31726, leg. C. Moesch, unlimited loan from ETHZ, Ve. S. 6686, x 1. 


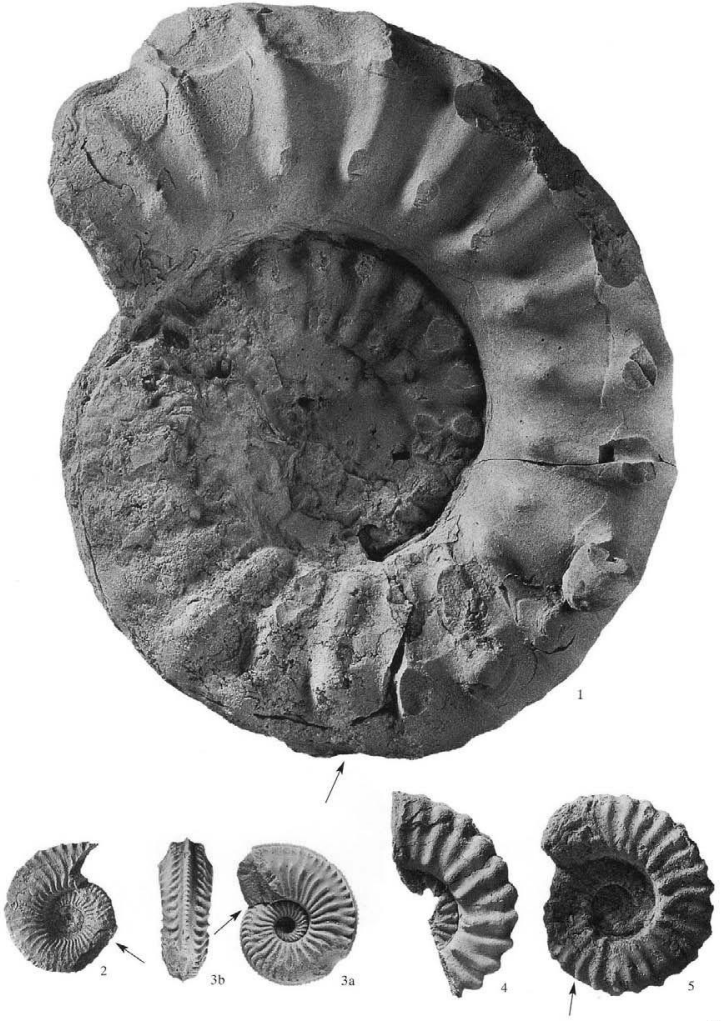


Fig. 1 - Orthosphincies (Praeataxioceras) sp.gr. laufenensis (Sifmiradzki), Bimammatum Zone, Bimammatum Subzone, Hornbuck Member, section RG 76, bed 12, Hornbuck near Riedern am Sand, Erzingen D (Unterklettgau). Complete adult with lappct. J 31722 , lcg. R. Gygi, x 1.

Fig. 2 - Taramelliceras (Metahaploceras) wenzeli (OPPEL), Planula Zonc, Planula Subzone, Wangental Member, section RG 78, bed 60, Mülitobel, Wilchingen SH (see Gral 1969, pl. 16). J 32276, leg. R. Gygi, x 1.

Fig. 3 - Taramelliceras (Metahaploceras) wenzeli (OPpEL), top of Bimammatum Zone, uppermost Hauffianum Subzone, Knollen Bed, section RG 70, bed 57, large quarry, Mellikon AG. J 32277, leg. R. Gygi, ×1.

Fig. 4 - Subnebrodites laxevolutus (FontANNES), Planula Zone, Planula Subzone, upper Letzi Member, section RG 70, bed 108, large quarry, Mellikon AG. J 32275 , leg. R. Gygi, $\times 1$.

Fig. 5 - Subnebrodites planula (QueNstedr), Planula Zone, Planula Subzone. Wangental Member. section RG 84, bed 14 (unpublished), township quarry, Hemmenthal SH. J 31723, leg. J. Dosza, $\times 1$.

Fig. 6 - Orthosphinctes (Orthosphinctes) colubrinus (RfinfeKE), Bimammatum Zone, Bimammatum Subzone, Hornbuck Member, section RG 76, bed 5, Hornbuck near Riedern am Sand, Erzingen D (Unterklettgau). Adult with part of lappet. J 32267 . leg. R. Gygi, $\times 1$. 

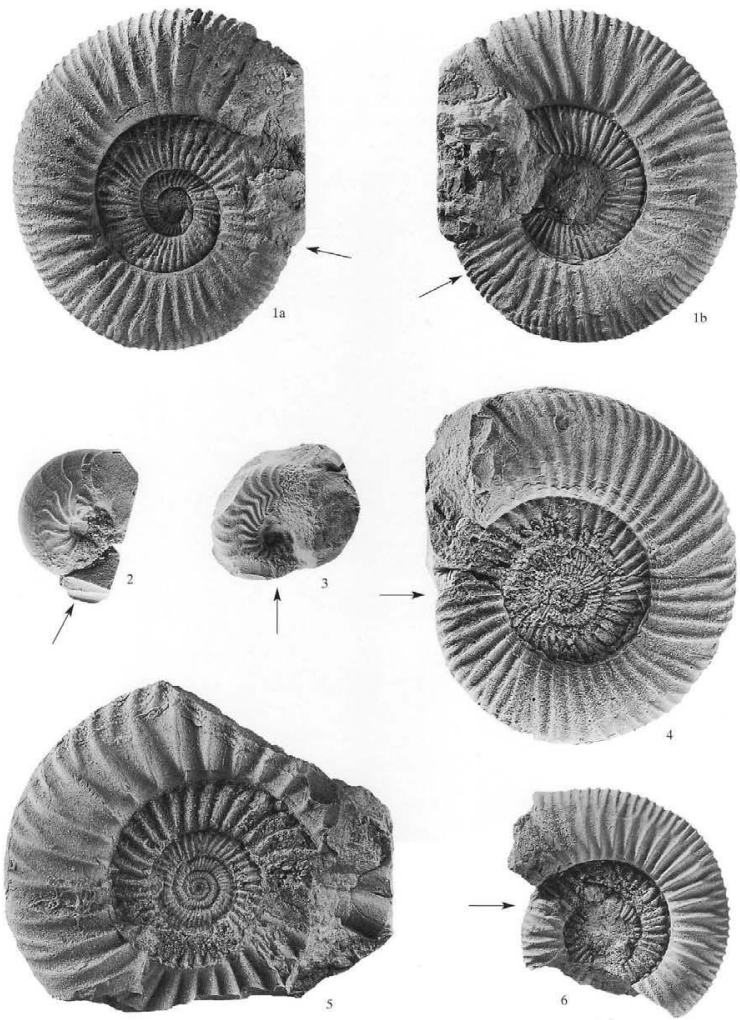
Plate 12

Fig.1-Ringsteadia suebica n.sp, Bimammatum Zone, Hauffianum Subzone, Knollen Bed, Dreifaltigkeitsberg near Spaichingen D. J 31724 , leg. L. Rollier, unlimited loan from ETHZ, $\times 0.6$.

Fig. 2 - Glochiceras (Lingulaticeras) lingulatum (QueNstzdT). J 31725, × 0.6. 


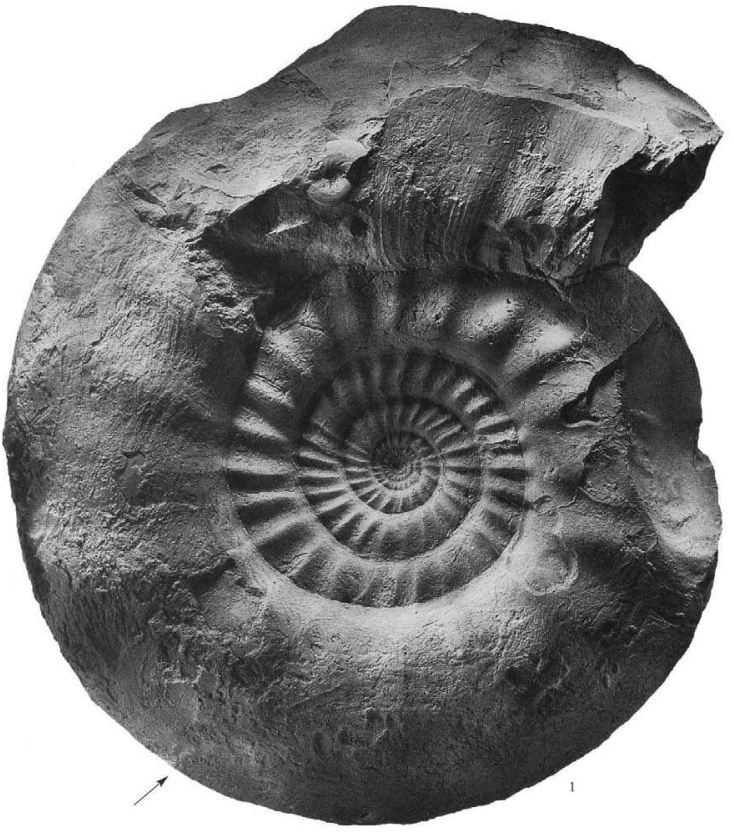


Plate 13

Fig. 1 - Wegelea gredingensis (WEGELE), Bimammatum Zone, Hauffianum Subzone, upper Kussaburg Member, section RG 85 , bed 55 (unpublished). Im wisse Rise, Beggingen SH. Near-complete adult with premature peristome. J 31720 , leg. R. Gygi, $\times 1$.

Fig. 2 - Sutmeria (Sumeria) platynota (REINECKE), morphotype A Schairer, Platynota Zone, lower Schwarzbach Formation, section RG 239, bed 22, southernmost quarry at Summerhalde, Schaffhausen. J 23630, leg. R. \& S. Gygi, × 2.

Fig. 3 - Sumeria (Suneria) galar galar (OPPEL). Planula Zone, Galar Subzone, base of Schwarzbach Formation, section RG 239. bed 18 , southernmost quarry at Summerhalde, Schaffhausen. J 23622, leg. R. \& S. Gygi, $\times 2$.

Fig.4-Subnebrodites schroederi (WEGELE), Planula Zone, Planula Subzone. lower Wangental Member, section RG 82, bed 134, Steimürlichopf quarry in Churz Tal, Siblingen SH. J 31714, leg. R. Gygi, x 1.

Fig. 5 - Orthosphinctes (Orthosphinctes) colubrinus (REINECKE), Planula Zone, Planula Subzone, lower Wangental Member, section RG 82 , bed 134, Steimürlichopf quarry in Churz Tal, Siblingen SH. J 31712, leg. R. Gygi, × 1 , 

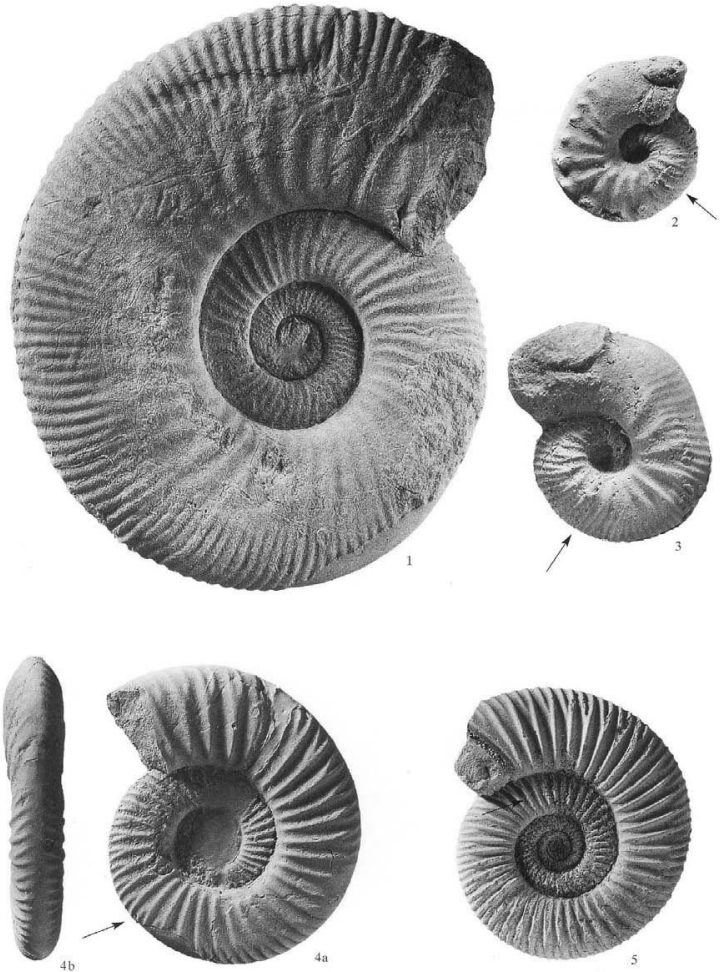
Plate 14

Fig. 1 - Ataxioceras (Parataxioceras) cf. pseidoeffrenatum Wegele. Hypselocyclum Zone, lower Baden Member, section RG 70, bed 124, large quarry. Mellikon AG.J 31721 , leg. R. Gygi, $\times 1$.

Fig. 2 - Ataxioceras (Parataxioceras) lothari huguenini Arrops, Hypselocyclum Zone, lower Baden Member, section RG 70, bed 124, large quarry, Mellikon AG. J 26388, leg. R. \& S. Gygi, × 1.

Fig. 3 - Idoceras balderum (OpPEL), Divisum Zone, lowermost Wettingen Member, section RG 62, bed 124, cliff east of Schrannechopf, Villiger Geissberg, Villigen AG. J 31719, leg. R. Gygi, × 1.

Fig. 4 - Sireblites tenuilobatus (OPPEL). Hypselocyclum Zone, lower Baden Member, section RG 70, bed 124, large quarly, Mellikon AG. J 32269, leg. R. Gygi, x 1.

Fig. 5-Rasenia (Eurascuia) trifurcata (REINECKE), Hypselocyclum Zone, lower Baden Member, section RG 70, bed 124, large quarry, Mellikon AG. I 26452, leg. R. \& S. Gygi, × 1. 


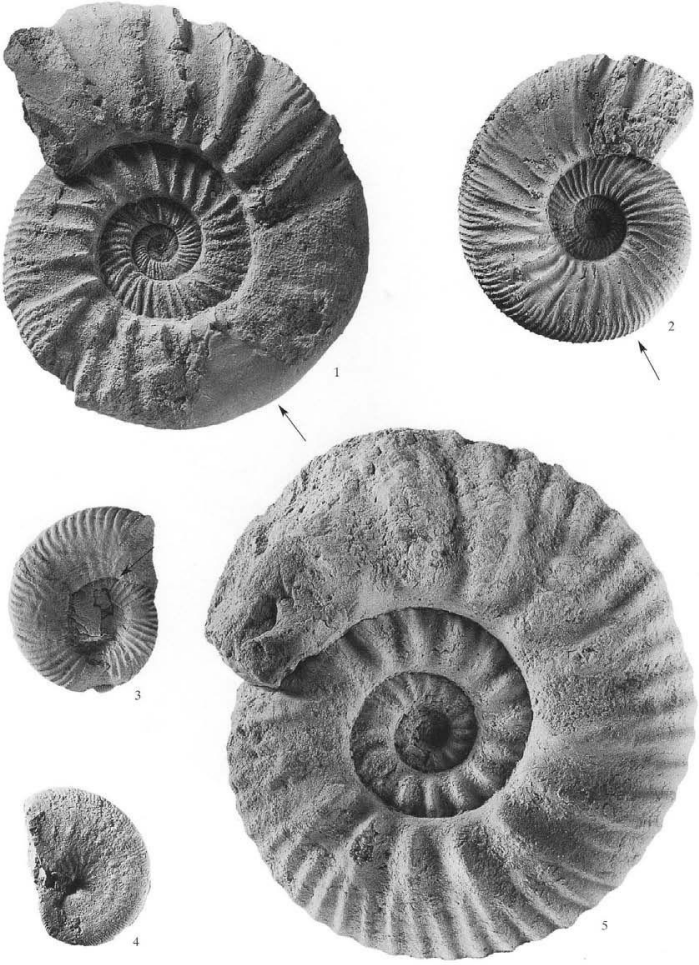


Plate 15

Fig. 1 - Orthaspidoceras uhlandi (OpPEL), Divisum Zone, lower Wettingen Member, section RG 70, large quarry, Mellikon AG. J 22901. don. Schweizerische Sodafabrik, $\times 1$. 


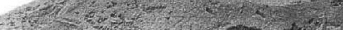

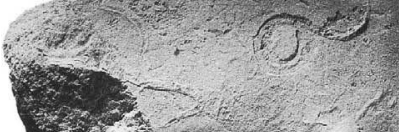

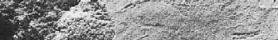

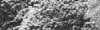

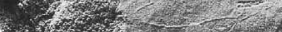
-
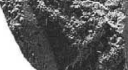
$x<x^{2}$
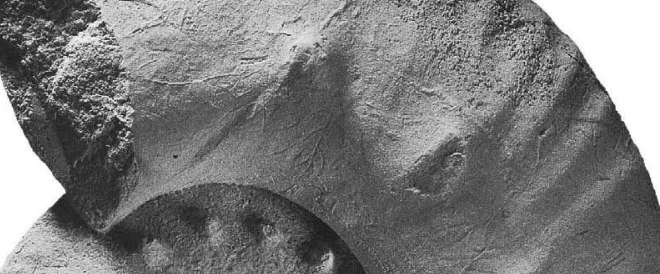

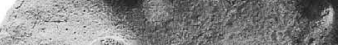

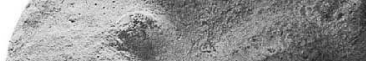

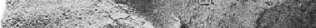

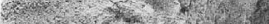
Q.

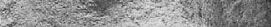
W.7.

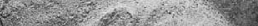

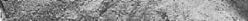
3.

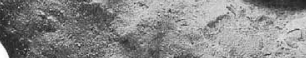

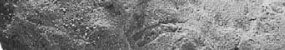

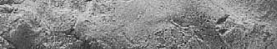
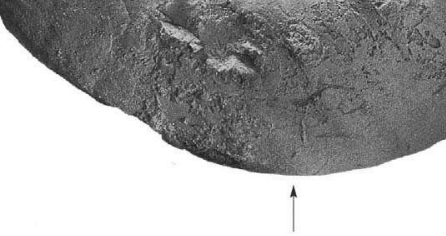